\title{
Szociális szakemberek képzése határon innen és túl
}

\author{
Szerkesztette: \\ Rákó Erzsébet \\ Szabó Gyula
}


A kiadvány a HURO-1001/268/2.3.1. „Határmenti együttmüködés erősítése a szociális szakemberek képzése és munkaerö-piaci orientációja területén - Deepening of cross-border cooperation in the field of training and labour market orientation of social professionals" projekt támogatásával készült.

Jelen publikációk tartalma nem feltétlenül tükrözi az Európai Unió hivatalos álláspontját.

\author{
Lektorok: \\ Kelemen Lajos \\ Molnár Endréné \\ Rákó Erzsébet \\ Szabó Gyula
}

ISBN 978-615-5372-00-1

(C) Belényi Emese, Flóra Gábor, Gombik Judit, Kelemen Lajos, Klement Mariann, Láczay Magdolna, Martos Tamás, Mojzesné dr. Székely Katalin, Molnár Péter, Nemes Magdolna, Nistor Mihaela, Rákó Erzsébet, Sárkány Péter, Szabó Gyula, Szerepi Sándor, Szilágyi Györgyi, szerzők 2013

(C) Belvedere Meridionale, kiadó 2013

Kiadta: Belvedere Meridionale

Felelős kiadó: Jancsák Csaba

Borítóterv: Majzik Andrea

Müszaki szerkesztés: ZKÖ, Belvedere Meridionale 


\section{Tartalom}

Előszó 5

Szociálpedagógia - képzés

BELÉNYI EMESE - FLÓRA GÁBOR: A társadalmi-nevelési inklúzió eszmerendszerének alkalmazási lehetőségei a szociális munkás képzésben 9

SÁRKÁNY PÉTER: Az elmélet gyakorlata 37

MOJZESNÉ DR. SzÉKELY KATALIN: „Rendezni végre közös dolgainkat” - tájékozódás a világban, eligazodás a környezetben, önismeret. 47

Nemes MaGdolnA: A szociálpedagógus hallgatók kommunikációjának fejlesztéséhez 66

Szociálpedagógia - színterek

SZILÁGYI GYÖRGYI - GOMBIK JUDIT: Egyházi szociális szerepvállalás a szociális ellátó rendszerben

RÁKÓ ERZSÉBET: Közigazgatási reformok hatása a gyermekvédelmi és gyámügyi igazgatásra

Szociálpedagógia - ismeretek

LÁCZAY MAGDOLNA: A tehetséggondozás megjelenése a modern magyar oktatáspolitikában

KELEMEN LAJOS: Nevelési stílusok szerepe az emberi kapcsolatok alakulásában.

KLEMENT MARIANN: Alternatív vitarendezés az iskolában 130

SZEREPI SÁNDOR: Szocializáció a kisebbség többségében

Nistor MiHAELA - MARTOS TAMÁS - MolNÁR PÉTER: „Csak azt szeretném, ha szeretnétek!" A kötődés és a családi minták hatásai a páros megküzdésre

SZABÓ GYULA: A gyermekek életminőségének vizsgálata - regionális különbségek Magyarországon 



\section{ELŐSZÓ}

A „Szociális szakemberek képzése határon innen és túl” című kötetben a szociális képzések tartalmához, színtereihez valamint a szakemberek által elsajátítandó ismeretekhez kapcsolódóan talál tanulmányokat az olvasó.

A könyv első nagy egységének tartalmát úgy állítottuk össze, hogy az a szociális szakemberek elméleti és gyakorlati képzését segítse. A társadalmi-nevelési inklúzió alkalmazási lehetőségeit tekinti át a szociális szakemberek képzésében Belényi Emese és Flóra Gábor. Sárkány Péter a szakmai hitelesség kérdéseit, különböző szakma elméleteket mutat be, majd ezekkel összefüggésben von le következtetéseket a szociális munka szakmai hitelességét illetően. A „Határmenti együttmüködés erősítése a szociális szakemberek képzése és munkaerő-piaci orientációja területén" címü projekt keretében megszerzett elméleti ismeretek alkalmazásának gyakorlati tapasztalatait foglalja össze Mojzesné Székely Katalin tanulmánya. A fejezet végén a szociálpedagógusok képzésében kiemelt fontossággal bíró kommunikációt, illetve annak fejlesztési lehetőségeit mutatja be Nemes Magdolna.

A második nagyobb fejezetben a szociális szakma színterein megvalósuló egyházi szerepvállalás történetét és jelenlegi helyzetét követhetjük nyomon Romániában Szilágyi Györgyi és Gombik Judit tanulmányában. Érdekesség, hogy a szerzők gyakorlati példákon keresztül szemléltetik az egyházak szerepvállalását a szociális szolgáltatások terén. A gyermekvédelemben, a gyámügyi igazgatás terén 2013-ban bekövetkezett változásokat mutatja be Rákó Erzsébet, ezzel segítve a hallgatók/oktatók eligazodását a folyamatosan változó gyermekvédelmi rendszerben.

A kötet harmadik nagy egységében a tanulmányok olyan elméleti ismereteket tartalmaznak, amelyek a szociális képzésben részt vevő hallgatók szakmai felkészülését mozdítják elő. Kelemen Lajos a különböző nevelési stílusokat mutatja be, és ezek szerepét ismerteti az emberi kapcsolatok alakulásában. Az alternatív vitarendezésre vonatkozó elméleti ismereteket tekinthetjük át Klement Mariann jóvoltából. A szerző összefoglalja a resztoratív szemlélet lényegét, valamint a mediáció alkalmazásának előnyeit. Szerepi Sándor tanulmánya a Romániában élő roma kisebbséghez tartozó, óvodás korú gyermekek nyelvi szocializációjának sajátosságaira hívja fel az olvasó figyelmét. 
A kötődés pszichológiai aspektusait, a páros megküzdésre vonatkozó elméleteket és egy kutatást mutat be Nistor Mihaela, Martos Tamás és Molnár Péter. A kutatásban Magyarországon élő párok diádikus megküzdését vizsgálták kérdőíves módszerrel. Láczay Magdolna a tehetséggondozás elméletét Mönks-Renzulli modelljén keresztül szemlélteti, valamint a modern oktatási rendszerek kialakulásának történetét tekinti át a tehetséggondozást is szem elött tartva.

A kötet mind az elméleti ismeretek, mind a gyakorlati tapasztalatok vonatkozásában igen gazdag. Ennek köszönhetően bízunk benne, hogy a hallgatók, az oktatók, a tereptanárok, a pályán lévő illetve a továbbképzésben részt vevő szociális szakemberek érdeklődését is sikerül felkelteni a témák iránt.

2013. február 15 .

A szerkesztök 
Szociálpedagógia - képzés 



\title{
Belényi Emese $^{1}$ - Flóra Gábor ${ }^{2}$
}

\section{A TÁRSADALMI-NEVELÉSI INKLÚZIÓ ESZMERENDSZERÉNEK ALKALMAZÁSI LEHETŐSÉGEI A SZOCIÁLIS MUNKÁS KÉPZÉSBEN}

THE POSSIBLE WAYS OF USING THE SOCIAL-EDUCATIONAL INCLUSION CONCEPT IN THE SOCIAL WORKER TRAINING

\begin{abstract}
The social worker training has started in 1991 in the Sulyok István Calvinist College (the predecessor of the Partium Christian University) and the students, who graduated in 1996 were among the first social professionals with higher education qualification. In the past few years European common policies changed in many aspects, the requirement if equal opportunities became more important in the field of educational, social and employment policy. These requirements are closely connected to the principle of overcoming social exclusion and reaching a higher level of inclusion. This paper examines the realization of these goals based on an interview survey carried out in Oradea with the participation of several social institutions.
\end{abstract}

\section{Bevezetés}

Nagyváradon, a Sulyok István Református Főiskolán 1991-ben indult ötéves vallástanár- szociális munka szakos képzés, amelynek végzettjei 1996-ban romániai viszonylatban elsőként vehettek át tanulmányaikat magyar nyelven végzett szociális szakemberként felsőfokú diplomát. A jövőtervezésben, stratégiai elöre-gondolkodásban ez a képzés mondhatni, megelőzte korát, hiszen abban az időben az országban még alig léteztek állami szociális ellátó intézmények, a szociális munkások iránti

\footnotetext{
${ }^{1}$ Belényi Emese egyetemi tanársegéd, Partiumi Keresztény Egyetem, Nagyvárad

${ }^{2}$ Flóra Gábor egyetemi tanár, Partiumi Keresztény Egyetem, Nagyvárad
} 
kereslet szinte kizárólag a civil és az egyházi szférában jelentkezett, ott is csak minimális szinten.

Az azóta eltelt két évtizedben sok minden jó irányba mozdult el. A szociális ellátórendszerek az európai uniós csatlakozási folyamat során egyre inkább konszolidálódtak és bővültek, a törvényes és intézményi keret - bár továbbra is számos hiányosság és ellentmondás jellemzi fokozatosan elindult az eurokonformitás útján. A nagyváradi magyar nyelvü szociális munkás képzés a Főiskola örökébe lépett Partiumi Keresztény Egyetemen 2002-ben önállósult, levált a vallástanári szakról, 2005-ben pedig megkapta a végleges akkreditációt. Végzettjei közül egyre többen találják meg helyüket a régió intézményeiben. Többen közülük továbbra is együttmüködnek az egyetemmel, szakmai tudásukkal, saját kapcsolati tőkéjük felhasználása révén támogatják a hallgatók új nemzedékeinek képzését és szakmai beilleszkedését.

Időközben az európai uniós közpolitikák is jelentős átalakuláson mentek át. Az esélyegyenlöség biztosításának követelménye az oktatáspolitika, szociálpolitika és foglalkoztatatáspolitika centrális célkitüzésévé vált az európai uniós dokumentumokban és az azokat megalapozó elméleti szakirodalomban egyaránt. Ez a követelmény szervesen kapcsolódik a társadalmi exklúzió leküzdésének, a lehető legmagasabb szintü inklúzió elérésének alapelvéhez. Olyan új fogalmak, fogalmi rendszerek kerültek ezáltal a szakpolitikusok és felsőoktatási szakemberek érdeklődésének középpontjába, amelyek operacionalizálása, gyakorlati bevezetése jelenleg még a fejlett nyugat-európai országokban sem tekinthető befejezett, egyértelmüen letisztázott folyamatnak.

A továbblépés megtervezésében különösen értékesek lehetnek tehát azok a tapasztalatok, tanulságok, amelyek az inklúzió alapelveiből fakadó szakmai értékek és segítési módozatok elsajátítása tekintetében a szociális képzés mindennapi gyakorlatában felhalmozódtak. Jelen tanulmányunkban az elmúlt években összegyüjtött - szakdolgozatokban kifejtett - hallgatói vélemények értelmezése révén és a terepgyakorlat néhány példájának bemutatásán keresztül vizsgáljuk az inklúziós értékek felsőfokú szociális munkás képzésen belüli elsajátításának folyamatát. Az inklúzió eszmerendszerének elméleti alapjaiból, közpolitikai értelmezéseiből kiindulva, valamint a partiumi magyar nyelvű szociális munkás képzés két évtizedes tapasztalatára építve arra a kérdésre keresünk választ: mit tehetünk annak érdekében, hogy az inklúziós értékek minél mélyrehatóbban meghatározzák az eljövendő szociális munkások szakmai arcélét. 


\section{Az inklúzió értelmezései}

„Minden olyan társadalomban, amelyben jelentősek az egyenlőtlenségek, a kormányzatnak biztosítania kell nemcsak a jövedelmek, a javak és az alapvető szolgáltatások növekvő minimumait, hanem az önbecsülés, a társadalmi mobilitási esélyek és a döntéshozatal számos színterén való részvétel javuló minimumait is". (Miller et al., 1967, p.17) Az inklúzió és az aktív részvétel elengedhetetlen az emberi méltóság megőrzéséhez és az emberi jogok gyakorlásához." (Salamancai Nyilatkozat 1994). Az ENSZ 1995 koppenhágai világtalálkozóján az exklúzió ellen is állást foglal, felvállalja a társadalmi integráció erősítését “olyan biztonságos és igazságos társadalom révén, amely az emberi jogok erősítésére és védelmére, diszkriminációmentességre, toleranciára, esélyegyenlőségre, szolidaritásra, biztonságra és mindenki részvételére épül, ideértve a hátrányos helyzetü és sebezhető embereket és csoportokat is." (Ferge 2000, p. 131)

Az inklúziós politikák vonatkozásban 1996-ban történt jelentős áttörés. (European Commission 1996) Ekkor fogalmazták meg először az egyenlő esélyek biztosításának alapelvét, mint centrális célkitüzést. Az Európa Tanács 1998. évi (1355) ajánlása a társadalmi életből való kizárás multidimenzionális- és folyamat-jellegét emeli ki, amely „,magába foglalja a társadalmi, gazdasági, politikai és kulturális életben való részvétel nem megfelelő szintjét, egyenlőtlenségeit, vagy teljes hiányát. Az exklúzió a társadalmi elszigetelődéstől a társadalomból való teljes kitaszítottságig terjedhet”. (Council of Europe 1998)

A társadalmi inklúzió eszmerendszerének közpolitikai intézményesülési folyamatában fontos előrelépés volt az Európai Unióról szóló szerződés módosítása, amely a szociálpolitikát és foglalkoztatáspolitikát az európai közösségi politika szintjére emelte. 2000-ben az Európai Bizottság elfogadta az „Akadálymentes Európáról” szóló jelentést (European Commission 2000), ugyanebben az évben pedig az Európai Unió Tanácsa kiadott egy, a tagállamok számára kötelező direktívát a fogyatékkal élők esélyegyenlőségének biztosítására. Az erre vonatkozó - 2000-ben elfogadott - cselekvési terv 2010-ig fogalmazta meg ezen a területen a feladatokat (Council of the European Union 2003).

E vonatkozásban a legfrisebb dokumentum az Európai Bizottság 2010 november 17-én kihirdetett, az Európai Fogyatékosügyi Stratégiáról (2010-2020) szóló határozata (European Commission 2010), amely nyolc fó fellépési területet jelölt ki: akadálymentesítés, részvétel, 
egyenlőség, foglalkoztatás, oktatás és képzés, szociális védelem, egészség és külső fellépés. Ezeket a területeket annak alapján választották ki, hogy milyen mértékben képesek hozzájárulni a stratégia és az ENSZegyezmény átfogó célkitüzéseihez.

A változások eredményeként a társadalmi inklúzió (social inclusion) fogalma, amely eredetileg a szociológiában, majd a szociálpolitikai koncepciókban jelent meg mint a kirekesztéstől való mentességet kifejező pozitív fogalom (Ferge 2002), a közpolitikai napirend részévé vált, s ezzel párhuzamosan kapott teljes ,polgárjogot” a pedagógiai inklúzió gondolatköre is. (Schiffer 2008, p. 45). Közpolitikai tekintetben ez a gazdagodás elsősorban az ún. lisszaboni folyamatban történik, amely a nyitott koordináció módszere révén lehetővé teszi az ágazati politikák elsősorban a foglalkoztatási, a szociális és az oktatási politikák - összehangolását. (Halász 2004).

Ebben az értelmezési keretben az oktatási exklúzió - amely az oktatási szolgáltatáshoz való teljes körü hozzáférésből való kizáródást, illetve e szolgáltatásokhoz való hozzáférés terén mutatkozó egyenlőtlenséget, valamint a magas szintű tanulmányi teljesítmény elérésének társadalmi okok által determinált alacsonyabb esélyét jelenti - okát és egyszersmind okozatát is képezi-képezheti a munkaerőpiaci, társadalmi mobilitási esélyegyenlőtlenségnek, s ezen keresztül a társadalmi kirekesztettség többi megnyilvánulásainak. Arra is fel kell figyelnünk ugyanakkor, hogy az oktatási exklúzió olyan kulcspozíciót tölt be a társadalmi exklúzió újratermelődésében, ahol megfelelő társadalmi beavatkozással esély nyílik az egymást erösítő negatív folyamatok megszakítására. A 2000-es magyar közoktatásról szóló jelentés (Radó 2001) külön fejezetben foglalkozik azzal, hogy a társadalmi hátrányok nem szükségszerüen alakulnak iskolai hátrányokká: a pedagógiai tényezők meghatározók lehetnek az egyes gyerekek iskolai sikereiben.

Az inklúzió kifejezést ilyen értelemben - a esélyegyenlőségi elvnek alárendelt és a lehető leghatékonyabb társadalmi beilleszkedést elősegítő nevelési koncepcióként - először egy kanadai kerekesszékes fogyatékosságügyi aktivista: Marsha Snyderman Forest és barátai kezdték használni, akik 1989-ben az Action for Inclusion címü könyvükben így fogalmazták meg az inklúzív nevelés célját:

„A jó iskolákat még jobbá teszi, ha az iskola közelében élö összes gyermeket befogadják. A jó tanárokat még hatékonyabbá teszi, ha az osztály valamennyi tagját bevonják az aktiv tanulásba, mindenkinek egyéni feladatokat adnak, és a tanuláshoz szükség esetén többlettámo- 
gatást is nyújtanak. A tanulókat jobban fejleszti, ha különbözö képességü személyek is jelen vannak az életükben, és ha minden tanuló biztonságban érzi magát, mert egyéni segitséget kap, amikor szüksége van rá. A családokat megerösiti, ha a tanárok és a tanulók összefognak azért, hogy létrehozzanak egy olyan osztályt, amely mindenkiért tesz." (O'Brien-Forest 1989 In Schiffer 2008, p. 47)

Az inklúziós folyamat ebben az értelmezésben nem egyszerüen csak - és nem feltétlenül - arra vonatkozik, hogy a nevelési hátránnyal küzdő fiatalokat a speciális iskolából mainstream iskolákba vagy osztályokba helyezik át, hanem elsősorban egy új típusú kapcsolatrendszer és kommunikációs mechanizmus kialakulását is feltételezi szülök, nevelők és a gyerekek között. Sebba (1996, p. 2) szerint az inklúzió és az integráció között a következő alapvető különbség áll fenn: ,,...az integrációval be kívánják olvasztani az iskola meglévő struktúráiba az egyéneket vagy a gyermekek kis csoportját, míg az inklúziónál újra átgondolják a tanterv megvalósításának szervezeti kereteit" és azokat a feltételeket, melyekkel valamennyi tanuló haladását biztosítani tudják.

Ezzel hozható összefüggésbe Ainscow (1995) megállapítása, aki szerint az inklúzió révén megvalósul az iskolarendszer általános fejlesztése. Az iskolákat úgy szervezik meg, hogy valamennyi gyermek, ezen belül a fogyatékosok nevelési szükségleteit is maximálisan kielégítsék. Hall (1992) értelmezése szerint a fogalom azt is jelenti, hogy az együttes fejlesztésen túl, a gyermeket valóban szociálisan is befogadja az intézmény gyermek- és felnőttközössége, tehát hatékonyan megvalósul a diszkrimináció elleni küzdelem. Az iskola mindenki számára sokkal hatékonyabbá válik, hiszen ahogyan ezt Hegarty (1993) hangsúlyozza, az iskola befogadó jellegét a tanítási programok, a pedagógiai felkészültség, a szervezés és a tárgyi, személyi feltételek megléte adja. (Csányi - Perlusz 2001, p. 319)

Az inklúzió e stratégiáját nevezi Susan Tetler ,hozzunk létre rugalmas iskolákat" megközelítésnek. Az inkluzív iskolák célja - eltérően az „,integrált iskola” modelljétől - nem egyszerüen az, hogy a tanuló integrálódjon egy már kialakult érték- és normarendszerrel rendelkező csoportba, amelynek értékeihez és normáihoz alkalmazkodnia kell. Ehelyett, illetve ezen túlmenően - inkább abban látják szerepüket, hogy létrehozzanak egy olyan iskolai kultúrát, amely minden tanulót befogad. „A kiindulópont ebben az esetben, hogy minden tanuló a helyi tanulóközösséghez tartozik, és éppen ezért az erőfeszítéseknek arra kell irányulniuk, hogy olyan kultúrát teremtsünk. amely a gyermeket nem 
zárja ki a közösségből. A felelősség mindannyiunké, és megkívánja az iskola szerkezetének átgondolását, beleértve a tantervet, a munkamódszereket, a szervezeti kereteket, továbbképzéseket stb. (Tetler 2006, p. 36)

Az új megközelítésmód egyformán értékesnek ismeri el minden, a folyamatban részt vevő társadalmi kulcsszereplő hozzájárulását, a nevelési gyakorlatot pedig mindannyiuk összehangolt erőfeszítései közös produktumának tekinti. Ezáltal egy olyan nevelési közösség jön létre, amely a a pedagógiai eszköztáron túlmenően a problémamegoldás társadalmi lehetőségeit is igyekszik hasznosítani, esélyt biztosítva az érintettek nagyobb mértékü bekapcsolódásához, sajátos tapasztalataik hasznosításához, a nevelési célkitüzések sikerességét gátló szubjektív feltételrendszerek megváltoztatása érdekében. (Laluvein 2010)

A nemzetközi szakirodalom az inkluzív oktatási gyakorlat fontos jellemzőjeként jelöli meg a nevelés értelmi, érzelmi és szociális dimenzióinak egymással összefonódó, egymás pozitív hatását kölcsönösen erősítő felhasználását. E vonatkozásban különleges jelentőséggel bír a szociális és érzelmi tanulásnak (az angol nyelvü szakmunkákban Social and Emotional Learning -SEL) az inkluzív neveléssel való kölcsönviszonya. A SEL a személyiségfejlődésre, a személyközi kapcsolatépítési és problémamegoldó képességek és kompetenciák fejlesztésére irányuló nevelési és szocializációs folyamatként határozható meg. Ez a folyamat formális és informális környezetben valósul meg, hatékonyságát számos egyéni, helyzetfüggő és kulturális tényező kölcsönhatása befolyásolja. A személyiségcentrikus látásmódon túlmenően, a SEL nagy hangsúlyt helyez a támogató oktatási környezet kialakítására, ennek érdekében főként a nevelési tér szociális és emocionális összetevőire koncentrál. (Reicher, 2010)

Az inkluzív oktatás problematikáján belül egy másik - az előbbiekhez szorosan kapcsolódó - fontos kérdéskör a kulturális identitás megőrzésének, kifejezésének, újratermelésének lehetőségére vonatkozik. Az inkluzív nevelést az az alapvető szemlélet jellemzi, amely a tanulók egyéni különbségeit (akár társadalmi, akár kulturális, akár biológiai) komplexitásában tekintve, maximálisan figyelembe véve, azokból kiindulva, azokra építve alakít ki befogadó környezetet. A befogadó környezet egyben azt is jelenti, hogy a nevelési térben részt vevő valamennyi személy (tanárok, diákok, szülők) a kölcsönös együttmüködés szellemében megismerik, értékként fogadják el egymást és építenek az egyéni különbségekre (Torgyik 2004). Az integráció célja nem a látha- 
tatlanná válás, a beolvasztás, a hagyományok, kultúra, vallás elfelejtése, hanem éppen a láthatónak maradás, a megkülönböztető tulajdonságok megmaradásának lehetősége. (Szira 2005).

A társadalmi befogadás és felzárkózás feltételeinek kialakításában az élethosszig tartó tanulás (Life Long Learning) is fontos szerepet hivatott betölteni. A felnőttkori tanulás révén ugyanis olyan korrekciós, kompenzációs mechanizmusok építhetők be az oktatási rendszerbe, amelyek hozzájárulhatnak az elmúlt évtizedek egyenlőtlenséget, kirekesztettséget újratermelő szelekciós mechanizmusainak és oktatási gyakorlatok negatív hatásainak enyhítéséhez. A felnőttoktatás számos lehetőséggel bír a fogyatékosság, hátrányos helyzet, kulturális másság percepciójával összefüggő közhiedelmek, felsőbb- illetve alsóbbrendüségi előítéletek lebontásában is. A jelzett folyamat során kulcskérdésként jelentkezik olyan nevelési alkalmak, találkozási helyzetek létrehozásának szükségessége, amelyekben a különböző identitással rendelkező személyek tanulóként és oktatóként egyaránt megismerhetik egymást. (McLean 2008)

Az új társadalmi-politikai gyakorlat meghirdetése napirendre tüzte a kérdéskörre vonatkozó társadalomkutatás elméleti alapvetéseinek, fogalomrendszerének, koncepcionális és módszertani apparátusának megfelelő átalakítását is, amelynek lényege, hogy a megismerő funkciót abszolutizáló koncepciók helyett a társadalmi változás elősegítését felvállaló felfogások kerülnek mindinkább elötérbe. Egyrészt a napjaink értékválságára adott társadalomtudományi válaszként, másrészt pedig az emberi jogok, az esélyegyenlőség problematikájának a politikai ideológiában és gyakorlatban való felértékelödésének szociológiai lecsapódásaként mindinkább elterjedtebbé és egyre fontosabbá válnak az emberjogi megalapozottságú, normatív jellegü megközelítésmódok, amelyeket a hátrányos helyzetü társadalmi csoportok sorsának javítása iránti elkötelezettség jellemez. (Blau, 2010)

Napjaink szociológiai elméleteinek fontos témái többek között a globális és lokális társadalom kapcsolata, az identitás szerepének erősödése és sajátos alakulása a globális hatalmi-financiális-technológiai hálózatokból kiszorítottak körében (Castells 2004), a tiltakozó mozgalmak társadalmi változást előidéző szerepe (Bourdieu 1969), valamint a társadalmi változás lehetséges modelljei (Coleman 1964, Bohrnstedt 1969). A hagyományos-klasszikus szemléletmóddal szemben, amely programatikusan értéksemlegességre törekszik, a fennálló társadalmi struktúrákat adottságként felfogó, implicit módon a status 
quo-t támogató, a társadalmi-politikai gyakorlathoz a tudós távolságtartásával viszonyuló kutatói attitüdöket favorizálja, mindinkább érvényesül az a felfogás, amely a szociológia kognitív funkcióját a társadalmi lét optimalizálásának szolgálatába állítja.

A társadalom- és neveléstudományok - az esélyegyenlőségi elv szellemében - közös célt tüztek ki az inklúzió tekintetében, nem született még azonban konszenzus arról, melyek a legjobb utak e célok elérésére. $\mathrm{Az}$ erre vonatkozó szemléletmódok alakulását jelentős mértékü változékonyság, szemantikai két- vagy többértelmüség, nem kellőképpen letisztázott fogalmi-elméleti alapvetések jellemzik. Ez a tény nem utolsósorban az érintett csoportok heterogenitásához, az egyéni helyzetek sokféleségéhez vezethető vissza. A bevezetésre kerülő koncepciók főként a körülmények sokfélesége, valamint a részben ebből következő heterogenitásuk és helyzetfüggőségük miatt - sok esetben nem alkalmasak arra, hogy egész közpolitikai koncepciókat építsenek rájuk. E célból történő részleges hasznosításuk szelektív kritikai viszonyulást tesz szükségessé, sokrétü összehasonlító elemzési perspektíva alkalmazását igényli (Wright 2010).

Az inklúzió elősegítése érdekében bevezetett megoldások kétségtelenül fontos előrelépést jelentettek az oktatási szolgáltatásokhoz való egyenlő hozzáférés emberjogi megalapozottaságú érvényesítése terén, enyhítették a marginalizált családi helyzetủ tanulók térbeli és társadalmi szegregációját. Ugyanakkor hiányosságként könyvelhető el, hogy a reform megvalósítása során a hangsúly sok esetben főleg a „normál” iskolai környezetbe való beillesztésére esett, és kevésbé a megfelelö iskolai és iskolán kívüli - hatékony támogató környezet kialakítására. A"normalizációt”, a „felzárkóztatást” gyakran a beolvasztás szinonímájaként értelmező nevelési gyakorlatok az ,integrálni” kívánt tanulótól - kimondva-kimondatlanul - egyoldalú alkalmazkodást vártak el, ami sajátos identitásuk, a másságukban hordozott tipikus kulturális-közösségi értékek (például a hallássérültek esstében a siketkultúra és nyelv közösségépítő szerepének, értékének, vagy a roma közösségek esetében a saját kulturális identitás) feladását, a kulturális sajátosság társadalmi érvényesítéséről való lemondást feltételezte.

A nemzetközi szakirodalmat tanulmányozva nem kerülhetik el figyelmünket olyan értelmü jelzések, miszerint a kezdeti lelkesedést követően a nyugati támogató szakemberek, de a pedagógusok körében is egyre inkább terjedni látszik a változások kapcsán tapasztalható “öszszezavarodottság, frusztráció, vétkességérzet és kimerültség." Bourke 
(2010) a jelenség okát abban látja, hogy a változások meghonosítását nem előzte meg az új rendszer eszmei megalapozásául szolgáló - a fogyatékosságról, szocio-kulturális marginalitásról, különbözőségről és inkluzióról kialakított - előfeltevések kritikai elemzése, a rendszert életbeléptető és müködtető szakemberek ehhez sem elegendő időt, sem anyagi támogatást nem kaptak. A leginkább célravezető tehát az lenne, ha a reformokat annak fényében értékelnék: milyen mértékben visznek azok közelebb a kiindulóponként szolgáló inklúziós célokhoz, milyen tényleges hatást fejtenek ki a tanulói népességre, valamint a tanulókat és családjaikat támogató szakemberekre.

\section{Átértékelődések a szociális munkás képzésben}

Az elöbbiekben vázolt kontextusban a szociális szférán belül is fokozódik a rokon társadalomtudományoknak a szakterület szempontjából fontosnak ítélt eredményei iránti szükséglete. A segítséget igénylők társadalmi helyzetét befolyásoló okok vizsgálata természetszerüen összekapcsolódik a hatékony beavatkozás módozatainak feltárására irányuló olyszerü törekvésekkel, amelyek a közpolitikai szerepvállalás szükségszerüségét tűzik napirendre. A támogató szolgáltatásoknak egyénre és helyzetre szabottnak kell lenniük, megtervezésüknél az uniformizált megoldások helyett az alternatívák bővítésére kell törekednünk. (Fónai-Pásztor-Zolnai, 2007, 115-119). „A célkitüzés az, hogy a segítő szakember „ne csak vészhelyzetekben avatkozzon be, vagyis amikor már lényegében késő [... ] hanem, hogy munkájával pont az ilyen helyzetek kialakulását akadályozza meg, illetve csökkentse" (Kozma - Tomasz 2000, p 12).

A felkészülés erre a feladatra komoly kihívások elé állítja a szociális szakemberképzést is. Alapvető célkitüzésként fogalmazhatjuk meg e perspektívában a gyakorlat-orientáltság követelményét, vagyis azt, hogy a szociális munkások egyetemi szintü képzése során integráltan valósuljon meg az elméleti ismeretek, a kutató-értékelötársadalomtervező jártasságok, és a kutatási eredményeken alapuló hatékony társadalmi beavatkozások megvalósítására képessé tevő kompetenciák elsajátítása. Tapasztalataink szerint a fentiekben jelzett szakmai jártasságok kialakítása érdekében a szociális munkás hallgatók terepgyakorlata során jelentős hozadékkal jár, ha szakmai feladatként tüzzük 
ki számukra az adott településen vagy régióban müködő szociális intézményhálózat felmérését és kiértékelését.

Azáltal, hogy részt vesznek a szociálisan hátrányos helyzet leküzdésére irányuló projektek, programok és politikák kidolgozásában és segítséget nyújtanak a szociális ellátó rendszerhez tartozó szolgáltatások, támogatási formák és megelőzést célzó tevékenységek kialakításához és fejlesztéséhez, a hallgatók az alapvető módszerek és technikák elsajátítása mellett kialakítják annak képességét is, hogy kritikailag elemezzék és megújulás-orientált perspektívából értékeljék a meglévő szolgáltatásokat, eljárásokat, jogi és intézményi kereteket. Nézzék meg közelebbről, hogy milyen tényleges társadalmi inklúziós gyakorlat müködik és milyen hatékonysággal a sokszor önmagában is elégségesnek tűnő vonzó fogalomhasználat mögött. “Az iskolai integráció - ugyanúgy, mint a társadalmi integráció - önmagában... se nem jó, se nem rossz. Valamilyen fokú és jellegű integráció minden esetben megvalósul... és minden azon múlik, hogy ez az integráció hogyan valósul meg." (Slee 2007) Az inklúzió sikeressége szempontjából lényegbevágó annak feltárása, hogy az iskolák és más, a probléma megoldásában érdekelt/érintett intézmények milyen módon azonosítják és támogatják a sajátos nevelésü igényü tanulókat, milyen ismérvek és eljárások segítségével sorolják őket ebbe a kategóriába, valamint, hogy milyen jelentéstartalommal bírnak ezek az ismérvek és eljárások szélesebb oktatáspolitikai és szociálpolitikai összefüggésben.

A fenntiekben vázolt hallgatói tevékenységtípus megtervezése során a következő fő tanulási célokat határozhatjuk meg:

- A hallgató legyen képes a szociális intézményhálózatot lakóhelyi-környezeti összefüggésekben bemutatni és értelmezni.

- Vázolja fel és helyezze bele a különféle intézmények struktúráját az ellátórendszer egészébe.

- Térképezze fel az intézmények külső és belső feltétel- és kapcsolatrendszerét

- Összehasonlító perspektívában vizsgálja az intézmények müködését, menedzsmentjét, döntéshozatali mechanizmusát, az intézményi organogrammok felhasználásával.

- Kategorizálja és elemezze az intézményi szolgáltatások igénybevevöit, azok különböző csoportjait. 
- Összehasonlító perspektívában értelmezze az intézményi szolgáltatásokhoz való hozzáférés különböző módozatait és feltételeit.

- Tárja fel és elemezze az intézményi munkamegosztás sajátosságait.

- Foglalja össze, milyen pénzügyi források felhasználásával müködik a szociális intézményhálózat, milyen típusú finanszírozások léteznek a rendszerben.

- Vázolja és értelmezze az intézményhálózat müködésének és a szolgáltatások igénybe vételének jogi hátterét. (Belényi 2012)

E tevékenységek folyamán a hallgatóknak lehetőségük nyílik arra, hogy a társadalmi-oktatási inklúzió megvalósítását célzó szociális ellátórendszer és intézményhálózat müködési módját a szociális munkás, valamint a szolgáltatások igénybevevőinek nézőpontjából tekintve egyaránt megismerjék és kritikailag értékeljék. Munkájuk során igen hasznosnak bizonyulhat, ha a hallgatók az inklúziós folyamat elösegítésére hivatott világos cél- és és szempontrendszerrel rendelkeznek. Az alábbiakban néhány ilyen, a terepmunka során megismert helyzetek nagy többségében jelentős relevanciával bíró szempontot szeretnénk jelzésszerüen összefoglalni:

- A korai fejlesztés gyakorlata mennyire és milyen módon épül bele az inklúziót elősegítő szolgáltatórendszerekbe és milyen hatékonysággal müködik? Milyen tervek, elképzelések léteznek e tekintetben?

- Milyen oktatatáspolitikai szemléletmód(ok) játszanak szerepet az oktatási és szociális szolgáltatások kialakításánál, hogyan viszonyulnak egymáshoz ezek a szemléletmódok (konfrontáció, semlegesség, kooperáció, komplementaritás?) a szakemberek és döntéshozók körében, valamint a társadalmi köztudatban?

- Milyen strukturális jellegzetességek jellemzik a szociális és oktatási intézményrendszert, milyen átalakítási elképzelések kerültek kidolgozásra ezzel kapcsolatban, szem előtt tartva az inklúzió célkitüzéseit?

- Milyen elképzeléseket fogalmaztak meg/ ültettek át gyakorlatba a speciális iskolák pedagógiai szolgáltató központokká történő átalakulása irányában? Hogyan értékelhető a folyamat eddigi eredményessége és perspektívái? 
- Mennyire elterjedt a hátrányos helyzetü tanulók mainstreamoktatásba történő bekapcsolódása, az integrált oktatási formák a tanulók milyen kategóriái számára nyitottak/elérhetőek? Milyen sajátos szolgáltatás-csomagot biztosítanak a mainstream iskolák, milyen stratégiai-oktatáspolitikai koncepciók és pedagógiai gyakorlatok müködnek/vannak tervbe véve ebben a vonatkozásban?

- Milyen mértékben terjedtek el és hogyan müködnek az individualizált/az egyéni tanulói sajátosságok, nevelési szükségletek figyelembevételével kialakított oktatási programok, módszerek?

- Hogyan müködik a szülök és az iskola közötti kapcsolat, milyen intézményes vagy informális kapcsolattartási keretek léteznek, milyen koncepciók alakultak ki a kapcsolattartás mikéntjének, tartalmi vonatkozásainak fejlesztése tekintetében?

- Milyen intézményhálózatba illeszkednek a tanulók számára felkínált/elérhető oktatási szolgáltatások, hogyan kapcsolódnak egymáshoz az oktatási, foglalkoztatási és szociális szféra intézményrendszerei, jogi kerete és közpolitikai programjai a társadalmi inklúzió elősegítése érdekében?

- Milyen oktatáspolitikai programok, intézményes keretek müködnek az oktatók, nevelők képzése, továbbképzése, státusa, szakmai kompetenciái, pedagógiai lehetőségei tekintetében? Melyek az elöremutató tapasztalatok ezen a területen?

- Milyenek a hátrányos helyzetű tanulók továbbtanulási lehetőségei, milyen arányban jutnak el az oktatási rendszer magasabb szintjeire?

- Hogyan függ össze a továbbtanulási sikeresség a tanulók számára felkínált oktatási szolgáltatásokkal? Milyen kimeneteli (továbbtanulási, szakmai mobilitási) esélyekkel rendelkeznek az oktatási rendszer különböző formáiba (speciális oktatás, integrált oktatás szakmai segítségnyújtással, spontán integráció mainstream iskolában szakmai segítségnyújtás nélkül) és szintjeire bekerült/azokat elvégző tanulók? Milyen reformelképzeléseket fogalmaztak meg e vonatkozásban?

- Hogyan épül be a szakoktatás a hátrányos helyzetü tanulók számára felkínált/elérhető oktatási szolgátatások rendszerébe? Hogyan viszonyulnak egymáshoz a szakképzési, továbbtanulási és szakmai mobilitási lehetőségek? Milyen módon optimalizálható ezek kölcsönviszonya? 
- Milyen reformelképzelések, programok, projektek, civil társadalmi kezdeményezések fogalmazódtak meg/valósultak meg az inkluzív nevelési elvek/politikák/gyakorlatok életbe léptetésének vonatkozásában? Milyen tervek, perspektívák körvonalazódnak e területen?

A kutató tudományos igényességével és az eljövendő szociális szakember ekötelezettségével, felelősségérzetével végzett hallgatói terepmunka, a célcsoportok tagjaival és társadalmi környezetükkel, a segítő szakma képviselőivel kialakított kapcsolatok építése, ápolása során alakulnak-fejlődnek az eljövendő szakemberek tanácsadói-esetkezelöi kompetenciái is. Fontos területe e munkának az tevékenység, amelyet a hátrányos helyzetü, a társadalmi kirekesztés kockázatának kitett csoportok számára elérhető közösségi támogatási forrásokhoz való hozzáférés (intézmények, szolgáltatások, juttatások) elérhetővé tétele érdekében végeznek a hallgatók.

A szükségszerü kiindulópontot mindehhez a szakmaiság kritériumainak megfelelő kommunikáció és kapcsolattartás módozatainak elsajátítása jelenti, a szociális szolgáltatások igénybevevőivel és más társadalmi szereplökkel folytatott párbeszéd, folyamatos együttmunkálkodás során. A legfontosabb feladat, a szociális területen tevékenykedők szakmai ideálja ilyen értelemben lényegében két szóban foglalható öszsze: képessé tenni, hiszen az egyének képességeinek és társadalmi környezetük minőségének javítása nélkülözhetetlen előfeltételét képezi olyan befogadó társadalmak és iskolák kialakításának, ahol az alapvető jogelvek, a méltányosság elvei érvényesülhetnek.

\section{Inklúziós értékek a szociális munkás képzésben}

A szociális munkás szakma humanista alapjainak elsajátítása és a hozzá kapcsolódó felelősségérzet tudatosítása során az inklúzió eszmerendszerére épülő szakmai szocializáció jelenkori követelményei a teljesértéküséget, a minden szempontból egyenlő élet esélyének biztosítását tekintik elsődlegesnek. Ez az új látásmód az integrációt már sokkal inkább a pozitív kibontakozást szolgáló eszköznek, mintsem önmagában értékes célnak tekinti: a teljes befogadást, pontosabban a kölcsönös be- és elfogadást, az ,egyenrangú és egyformán értékes sokfélék" általi egymás gazdagítását helyezi a törekvések középpontjába. 
Az elérendő cél, hogy a marginális helyzetben levő személyek teljes értékü emberként egyenlő alapon részt vehessenek a tanulásban, munkavégzésben és a társadalom egész életében. (Ingstad és Whyte 1995, p 179).

Annak érdekében, hogy szociális szakemberként a jövőben hatékonyan bekapcsolódhassanak e célok megvalósításának folyamatába, igen nagy fontossággal bír, hogy képzésük során a hallgatók:

- Legyenek nyitottak a különböző társadalmi csoportok egymástól eltérő életstílusainak befogadó-elfogadó értékelése iránt, különös tekintettel a kulturális különbözőségekre és az alacsony jövedemű személyek, családok helyzetére.

- Sajátítsák el a szociális munkával összefüggő különféle szerepeket, amilyenek többek között a közvetítői, az érdekvédői, a facilitátori és a nevelöi szerepkör.

- Szakmaiságon alapuló, partneri kapcsolatokat alakítsanak ki és tartsanak fenn a szociális szolgáltatások igénybevevőivel, annak érdekében, hogy erősítsék problémamegoldó képességüket. Vonják be a szociális szolgáltatások igénybevevőit a tervezett változások megtervezésének és megvalósításának folyamatába. (Belényi 2012)

A hallgatók pályaválasztási döntéseinek megérlelődésében, az eljövendő szociális munkások szakmai arculatának, identitásának formálódásában igen fontos szerepe lehet annak, hogy szocializációjuk, személyiségfejlődésük, képzési folyamatuk során mikor és milyen szocializációs hatást generáló körülmények között találkoznak a hátrányos helyzethez kötődő vagy köthető különbözőséggel. Tapasztalataink szerint a Partiumi Keresztény Egyetem (PKE) szociális munkás hallgatóit a sokféleség jellemzi családi hátterük, a családi szocializáció során kialakult identitásbeli jellemzőik pályaorientációjukban játszott szerepe tekintetében is.

Nem egy esetben éppen a családi környeteben átélt hátrányos helyzet, valamint az ezekhez kapcsolódó méltánytalanság megtapasztalása vezette el a hallgatókat a kitörési esélyként, s egyben az elégtétel-vétel lehetőségeként is megjelenített szociális szolgálat, a szociális hivatás felvállalásához. Nyilvánvaló az ilyen típusú pályaválsztási motivációs háttér jelenléte a PKE szociális munkás képzésébe beiratkozott roma hallgatók, árvaházban felnőtt fiatalok, fogyatékossággal élő hallgatók, 
vagy olyan fiatalok esetében is, akiknek családtagjai között vannak fogyatékkal élök.

„,Jómagam is siket szülök gyermeke vagyok, több mint 20 évig ök neveltek, próbáltak az élet útján elindítani. Egészen közelröl láthattam azt, hogy bár társadalmunk teljes értékü, tiszteletreméltó és becsületes tagjai, mégis nap mint nap nehézségekkel kellett szembenézniük ahhoz, hogy halló embertársaik számára természetesnek tünö mindennapi feladataikat megoldják. Sok esetben lenézést, meg nem értést tapasztaltak tulajdonképpen azért, mert vagy nem értették meg öket, vagy nem is akarták.” B.M.

A hallgatók egy másik kategóriájához tartozókat családi hátterük nem "predesztinálta” a hátrányos helyzettel való korai szembesülésre, esetükben nem egyszer éppen az a momentum bizonyult meghatározónak a szakmaválasztásban, amikor a körülmények alakulása folytán hirtelen a maguk szépítés nélküli embertelenségében kellett megtapasztalniuk a társadalmi kirekesztés számukra addig jórészt rejtve maradt, a családi-közösségi viszonyrendszer és a nyilvánosság szürői által "szégyenlősen” eltakart megnyilvánulásait.

"Megdöbbentem, mikor kiderült, hogy a barátnömnek, akit akkor már három éve ismertem, hallássérült a növére. Öt is Kolozsvárra vitték a szülei három éves korában. Az az elkeseritö tény, hogy a barátnöm három évig titkolta, és soha nem beszélt a nővéréröl, mutatja, hogy menynyire félnek az emberek attól, ha valamelyik családtagjuk „más”, félnek a társadalom itéletétől, megbélyegzésétől. Épp a hallássérültekkel való tapasztalatom hiánya hivta fel a figyelmemet erre a társadalmi intoleranciára és az oktatási intézmények kirekesztö magatartására, éppen ezért társadalmi szempontból nagyon relevánsnak és égetőnek érzem ennek a problémakörnek a tárgyalását." K.CS

A mindennapi élet során, elöre nem látható időpontban és körülmények között bekövetkezett ilyetén "ráeszméléseket" az eljövendő hallgatók katarktikus életsors-formáló hatásként is megélhetik, különösen azokban az esetekben, amikor a pályaválasztás motivációs gyökereinél már valamilyen formában jelen van a "segíteni akarás" törekvése. 
„Elsődlegesen a téma lo éve érintett meg, amikor egy fogyatékos gyermekekkel foglalkozó óvodában kezdtem el dolgozni, minden elözetes képzés nélkül. A tehetetlenség dühe ébredt bennem, amikor a tudatlanság és kreativitás hiányának köszönhetően nem értünk el fejlödést és még csak azt sem tudtuk meg, hogy a gyerekek mit szeretnek vagy szeretnének csinálni." Sz.Zs

A társadalmi kirekesztés realitásának megtapasztalása nyomán válik nyilvánvalóvá a segítő szakma elsajátítását életpálya-célként kitüző fiatalokban az a szakadék, amely a társadalmi esélyegyenlőség kinyilatkoztatott, de a gyakorlatban alig érvényesülő elvei és a meglévő iskolarendszer, annak társadalmi exklúziót eredményező hatásai között áll fenn.

„Az iskolám nem volt befogadó szellemü, elit iskolának számított. A mennyiség- és eredménycentrikus politikája nem tolerálná azt, hogy a tanár az esetleges ismétlések miatt lassabban haladjon a tananyag leadásával. A város utcáin, szórakozó helyein se lehetett látni egy hallássérült személyt se, aki esetleg jelnyelvvel kommunikálna. A magyar szülök, speciális iskola nem lévén, csak Kolozsváron, bentlakásos intézménybe küldik hallássérült gyerekeiket, ez által megfosztva öket a család biztonságos, személyiségápoló légkörétöl. " K.CS

A ,felismeréstől a megismerésig” vezető nen könnyü úton a szociális segítőtevékenység iránt elkötelezett hallgatók szakmai idenitásának alakulásában kedvező hatása, katalizátor szerepe lehet azoknak a tapasztalatszerző szakmai élményeknek, amelyek során a mi régiónkban meglévőknél fejlettebb gyakorlatokkal ismerkedhetnek meg a társadalmi inklúzió területén.

Az angliai gyakorlati egy évem alatt lehetőség mutatkozott arra, hogy többet megtudjak egy jóléti állam a fogyatékossággal élő személyekhez való viszonyáról, megismerjem ellátórendszerét és annak gyakorlati következményeit, és megtanulhattam azt a társadalmi felfogást, mely egy civilizált országban uralkodik, és amelyik képes elfogadni és befogadni a más fizikumú embereket. CS.S.

A gyakorlati terepmunka megtervezése során lényeges szempontot képez, hogy a hallgatók megismerkedhessenek a hátrányos helyzetet 
meghatározó társadalmi-identitásbeli tényezők és körülmények, valamint az alkalmazott beavatkozási módozatok változatosságával. A sokrétü, a kérdéskör különbő vetületeit megvilágító gyakorlati tapasztalatszerzés nagy mértékben elősegítheti az elméleti ismeretek konszolidálását, az összehasonlító elemzési perspektíva sikeres alkalmazását a hallgatói kutató-tervező tevékenységek során.

„, Kutatásom célja az volt, hogy a témában jártas szakemberek segitségével feltérképezzem a nagyváradi hallássérült gyerekek integrációs esélyeit, megtaláljam azokat a faktorokat, amelyek pozitív irányba befolyásolják az integrációt. Továbbá, hogy meghatározzak egy olyan optimális feltétel- és környezetrendszert, amelyben a hallássérült gyerek integrációja zökkenömentes lehet.” Sz. Zs.

E megismerési folyamat során kristályosodnak ki a hallgatók értékrendszerében és elemzési szempontrendszerében azok a mindenki számára közös alapvető inklúziós értékek, amelyek a későbbiekben majd iránymutatóként szolgálnak egység és sokféleség, hasonlóság és különbözőség viszonyának árnyalt, a lehető legmagasabb szintü kölcsönös be- és elfogadás céljait hatékonyan szolgáló értelmezésében.

„,Kérdem én, mire van szüksége a fogyatékossággal élö embernek, ha nem ugyanarra, mint nekünk 'normális' embereknek. Szükségleteink ugyanazok, ugyanazon szükségletrendszerben keresgélhetjük, csupán emberi jellemzöink változnak, minthogy nincs két egyforma ember a földön. A fogyatékossággal élö emberek érzö és gondolkodó emberek, akik ugyanúgy vágynak az önmegvalósitó életformára” P.T.

A fogyatékossággal, hátrányos helyzettel, marginalizáltsággal kapcsolatos kérdéskörök, konkrét helyzetek feltérképezése és a beavatkozás megtervezése során lényeges, hogy a hallgatók világosan maguk előtt lássák az inklúziós folyamat alapvető célját, a gyakorlatban is érvényesülő esélyegyenlőség megteremtésének követelményét. Ezáltal válhatnak majd maguk is szakemberként egy gyökeres társadalmi mentalitásváltás előkészítőjévé.

„Elsödleges célom a fogyatékossággal élö személyek helyzetének vizsgálata a szociális ellátórendszer nyújtotta védelem keretében. Ezáltal szeretném felhívni a figyelmet a szemléletváltás szükségességére, egy 
nyugat európai országot bemutatva, mint modell értékü példát. Szeretném megismertetni mindazokat a tényezöket, melyek a fogyatékossággal élö személyeket hátrányba sodorják, és rámutatni arra, hogy nem csupán a gazdasági hátrány a felelös a fogyatékossággal élö személyek helyzetéért, hanem az állami szervek, szakemberek, a társadalom és maguk a fogyatékos emberek közremüködése is szükséges a szociálpolitikai törekvések gyakorlatba ültetéséért." A.SZ.

A hallgatók által megfogalmazott vélemények jól tükrözik azt a folyamatot, amelynek során a szociális munkások új nemzedékének szakmai identitástudatába egyre inkább szervesen beépül a meggyőződés, miszerint a társadalmi marginalitás leküzdésnek kulcsa az inkluzív társadalmi feltételrendszer kialakításában rejlik. Az erre irányuló erőfeszítések viszont csakis akkor lehetnek sikeresek, ha az érintett célcsoport tagjai is egyenrangú résztvevőként kapcsolódnak be a megoldáskeresébe, kezükbe veszik saját sorsuk irányítását.

„, Akadálymentes környezetre lenne szükség. Ezt az akadálymentességet közösen kell megvalósitanunk, nem hárítható csupán a nem fogyatékossággal élö emberekre, hanem ezt a sérült emberek is ugyanúgy feladatukként kell, hogy kezeljék." Sz.Zs

A megoldáskeresés esélyeinek feltárására irányuló törekvésükben a hallgatók olyan kulcsfogalmak jelentését sajátítják el, mint például a „kommunikációs technikák”, a „bizalomépítés”, a „szakmai professzionalitás”, a „szükségletorientáltság.” Azoknak a hallgatóknak, akik szociális intézményben nevelkedtek, vagy szociális intézmények munkatársaiként dolgoztak/dolgoznak, ez a tanulási folyamat arra is alkalmat ad, hogy az általuk belülről ismert intézmény realitását az elsajátított fogalmak és minőségi követelmények mércéjével mérjék és az előrehaladás igényének jegyében kritikailag értékeljék.

„Az én meglátásom szerint nem csak szakemberekkel van probléma, akik például szociális munkásként töltik be a státuszokat az intézménynél, hanem az intézmény vezetöségével is. Sokuknak hiányzott a képesitése, ami későbbiekben nagy hiány volt, emiatt alakultak ki nehézségek. Nem volna-e az a megoldás, hogy most az intézet a fiatalokat' ' kiszolgálja'? De semmilyen bizalom nincs meg, pedig akár egy párbeszédet is kezdeményezhetne a vezetöség vagy éppen a segitó szakember. A 
nagy problémák közé sorolhatnám, hogy nem voltak hajlandó semmilyen megoldást keresni arra, hogy ha fiatal szeretne beszélni a szociális munkással, akkor azt a vezetösség ne hallja. Mert a fiatalt csak a félelem töltötte el, ha a segítövel konzultált. Ennek az oka az volt, hogy minösitve érezte magát és a késöbbiekben emiatt nehéz helyzetbe hozhatták a fiatalt." (gyermekvédelmi intézményben felnevelt hallgató).

Az inklúzió megvalósításának sajátos problémájaként jelentkezik régiónkban, hogy a jelenleg még domináns társadalmi-pedagógiai gyakorlatban az integrációs elv gyakorlati kivitelezési módja - többékevésbbé nyíltan felvállalt - homogenizáló üzenetet hordoz, feltételezi, hogy a marginalizált helyzetben levő személy más akarna lenni, mint aki ő valójában, hogy túl akarna lépni, vagy túl kellene lépnie saját helyzetén mág akkor is, ha ez saját identitásának feladását jelentené. (Swain, French, 2004, p. 31). Erőteljesen vetődik fel tehát az integrációért fizetendö, önazonossággal, kulturális hovatartozással kapcsolatos „ár” kérdése. Az alábbi, gyermekvédelmi intézményben felnőtt, roma idenitással rendelkező hallgatótól származó vélemény alátámasztja, hogy reális célkitüzés lehet ezen a téren is a sokrétü, árnyalt látásmód és különböző vélemények befogadására, termékeny eszmecserékre nyitott szellemi párbeszéd feltételeinek kialakítása a hallgatókkal.

„Akad egy-két ember az intézményen belül, aki szívesen beszéli a roma nyelvet. Van olyan fiatal, aki akkor gyakorolhattta a roma nyelvet, amikor származási családjának tagjai meglátogatták a nevelö intézetben. Ez által ő maga úgy érezte, hogy a családhoz is tartozik, mivel a kommunikáción keresztül biztonságban érezte magát, emellett örömmel beszélte a roma nyelvet. Azonban olyan fiatal is akad, akinek szégyenérzete van amiatt, hogy ö roma származású. Vannak olyan fiatalok is, akik bevállalják hovatartozásukat, de nem mindenben. Pl. 'Én roma vagyok, de nem tudom a nyelvet, több mint tíz éve nem élek a családommal. ' Legtöbbjük nem mondja, hogy ő roma 'Hát én brazil vagyok vagy akár lehetnék spanyol is' Jól látszik az öltözködésükön, mert például brazil pulóvert vagy akár csak cipöt használnak. Sajnos nincs követendö modell számukra, hogy identitásukat fel tudják vállalni. Ami egy jó modell lenne, ha ebböl a csoportból egy magasabb státust betöltö személy bevállalná, hogy ö roma, de ettöl még nincs amiért szégyenérzete legyen. " S.R. 
Az önazonosság szerepével kapcsolatos szemléleti paradigmaváltás hatását jól tükrözi az a hallgatói vélemény, amelyben - a siketoktatás viszonylatában - a nyelvi-kulturális identitás tiszteletben tartására épülő megoldások nem legyőzendő akadályként, az integráció visszavetőjeként, hanem ellenkezőleg, erőforrásként, a társadalmi kirekesztettség leküzdésének járható útjaként jelenítődnek meg.

„Véleményem szerint fontos, hogy a hallássérült személyeknek egyaránt meg legyen a lehetősége magas szinten megtanulni és használni mind a jelnyelvet, mint pedig a verbális nyelvet. Ezáltal bármelyik kultúrában (siket és halló) meg tudják állni a helyüket, teljes életet tudnak élni. Illy módon, úgy gondolom, nagyobb esélyük lenne arra, hogy ne csak főleg szakmunkásképzőt végezzenek, hanem akár a felsőoktatásban is jó eredményeket érjenek el és nagyobb számban is megjelenjenek az értelmiségi hallássérültek." B.M.

\section{Intézményi gyakorlaton részt vevő hallgatók tapasztalatai}

\section{Információs és Tanácsadó Központ Fogyatékkal Élők Számára (CICPD)}

A fogyatékkal élők számára létrehozott tanácsadási központ Nagyváradon 2001-ben alakult meg a romániai Caritas Konföderáció országos programjának részeként, $\mathrm{BACH}$ iroda (Tanácsadói iroda fogyatékkal élők számára) néven. Az ország több pontján található másik 10 irodával egyetemben, a $\mathrm{BACH}$ iroda is részese volt egy átfogó programnak, melynek célja a fogyatékkal élők életminőségének javítása és társadalomba való beilleszkedésük segítése. Mindemellett, már az iroda megalakulásakor törekedtek a helyi szinten müködő más szervezetekkel való együttmüködésre a célcsoportjaink javát szolgáló események megszervezésében.

Jelenlegi szolgáltatásaik elsősorban a Bihar megyei fogyatékkal élőket és hozzátartozóikat célozzák meg, azonban rendelkezésére állnak azoknak is, akik átmenetileg érkeznek Nagyváradra. Kedvezményezettjeik számára naprakész információkkal tudnak szolgálni mindenről, ami a fogyatékkal élők jogaival kapcsolatos és akár egyéni vagy csoportos tanácsadást is végeznek e személyek közösségbe való beilleszkedésének támogatására.

Tanácsadói tevékenységük mellett olyan kampányokat, nyilvános eseményeket is szerveznek, melyeknek célja a lakosság fogékonnyá 
tétele és megismertetése a fogyatékkal élők problémáival és mindennapjaikkal. Más szervezetekkel karöltve igyekeznek csökkenteni ezeknek a háttérbe szoruló embereknek a kirekesztettségét és általánosan elfogadottá tenni azt a tényt, hogy ők ugyanolyan értékes tagjai a társadalomnak, mint fogyaték nélkül élő társaik. (Belényi 2012, 96)

Az egyik ilyen - nagyváradi középiskolákra kiterjedő - kampányban részt vevő szociális munkás hallgató írja:

A program célja, hogy megismertessük a mai fiatalokkal, iskolásokkal a fogyatékosság fogalmát. Hogy tudják, mit is jelent ez. Olyan játékokat játszatunk velük, amelyek során kicsit megérzik, milyen lenne, ha ök is valamilyen hiányosságban szenvednének. Mi nem szöveggel álltunk eléjük, hanem játékosan vezettük rá őket arra, amit végül tudatosult bennük. Ezután a bevezetés után egy 'élö példával' mentünk második alkalomkor. Egy bácsi mutatkozott be, aki látássérült, és ö mesélt az életéröl, arról, hogy mennyi mindent elért az életében, és arról, hogy milyen nehézségekkel szembesült a sérültsége miatt. A diákok visszajelzése nagyon is pozitív volt a tanárok szerint, mivel sikerült az érdeklödésüket felkeltenünk ezzel a programmal, söt még arra is megkértek, hogy nem akarnánk-e a román osztályoknak is bemutatni. R.M.

\section{Kis Szent Teréz Óvoda}

Az óvodát 1999. aug. 31-től a nagyváradi ferencesrendi nővérek nyitották meg a sérült, különleges oktatást igénylő (enyhe középsúlyos értelmi fogyatékos, autista, mozgássérült, beszédhibás) gyermekek szellemi fejődéséért.

Az oktatás reggel nyolctól délután négyig tart. Az óvoda felvállalja a pszicho-szociálisan hátrányos helyzetü sérült gyermekek ellátását, gondozását, valamint a gyermek fogyatékossági fokának megfelelő szakirányú fejlesztését. A pedagógiai, gyógypedagógiai, logopédiai és kinoterápiás foglalkozások mellett nagy hangsúlyt kap a gyerekek morális, keresztény szellemü nevelése, illetve az önállóságra való nevelés.A speciális oktatási program mellett napi háromszori étkezést biztosítanak a gyermekek számára. Az óvodai vegyes csoportot 3-8 éves gyermekek alkotják, minimum 8, maximum 12 fös létszámmal. A gyermekek szociálisan hátrányos helyzetü családokból kerülnek ki, esetenként árvaházakból, kórházakból. (Belényi 2012, 99)

Az oktatásban két szakképzett óvónő, egy gyógypedagógus és egy kinetoterpeuta vesz részt. Az ő munkájukat segítik a PKE szociális 
munkás hallgatói, akik közül az egyik a következőképpen foglalja öszsze, mi az, ami leginkább emlékezetes maradt számára az ott töltött órákból.

„Azt tapasztaltam, hogy mindegyiket, ha közelebbröl megismered, megmutatja, hogy milyen érték is rejtőzik benne. Így persze lettek kedvenceim is, az egyik egy autista kisfiú, aki nagyon huncut tud lenni. Szeretek ott időt tölteni és ugyanakkor tanulni is, olyankor mindig valahogy feltöltődöm, és jó kedvü tudok lenni egész nap. Talán ők még jobb hatással vannak ránk, mint mi rájuk.” T.E.

\section{Posticum - Egalitas Játszóház}

A latin „,posticum” szó jelentése hátsó ajtó. Hátsó, azaz nem szokványos bejáratot keres magának, onnan közelít és bejut. Keresztény gondolkodásmód és lelkiség a kulcsszavai, így épít egy olyan házat, mely a kultúra, az ifjúság és a templom háza is. A Posticum első elnöke, Alois Sághy mondta róla: a Posticum ,ház, amely védettség, iskola, ahol az élet számára tapasztalatokat lehet szerezni, templom, ahol az élet értelme Jézus Krisztusban megtapasztalható." (P. Alois Sághy SDB, 21.5.2000) Ápolja azt az identitást, mely valakit emberré, vallásossá, intellektuellé tesz. Központtá válik, melyben a különböző vallások, a kulturális terek és az itt zajló aktivitások egyesülnek, és homogenizálódnak is. Filozófiája és az aktivitása is keres valamit, egy helyet mely „a nagyváradi egyházmegye fiataljainak és az egész romániai egyháznak kulturális, politikai, szociológiai és lelki találkozásainak folytonos tere.” (Belényi 2012, 100)

A nagyváradi Posticum Movimentumban otthonra lelt és minden évben megrendezésre kerülő Egalitas program célja és indíttatása Németországból származik, ahonnan az egyik programszervező osztotta meg azt az ötletét, hogy hozzanak létre egy olyan játékházat, ahol egészséges és sérült gyermekek együtt játszhatnak és megismerhetik egymás környezetét és életstílusát. Az Egalitas játszóház lényege, hogy speciális igényü és egészséges gyerekek játsszanak együtt. Abban kívánnak segítséget nyújtani, hogy a gyerekek a közös játék során fedezzék fel egymás különbözőségeit és hasonlóságait, és ugyancsak a közös játék erejével gyõzzék le az egymással szembeni esetleges elõítéleteiket.

A program lefolyatásában nagy szerepet kaptak az évek során a Partiumi Keresztény Egyetem szociális munkás hallgatói, akik részt vállaltak a gyerekek gondozásában és a szervezőket segítették. 
„A program célja elsösorban az, hogy az egészséges gyerekek el tudják fogadni a sérült gyerekeket, és hogy velük együtt tudjanak játszani, s hogy megértsék: nekik ugyan egy kicsit nehezebben megy, de öket is be lehet vonni a játékba és lehet velük együtt élvezni a tevékenységeket, hogy le lehet gyözni az elöitéleteket és türelmesnek, toleránsnak lenni nem is olyan nehéz." P.CS.

A szervezők tapasztalatai szerint a gyerekeknek nemcsak azért hasznos ez a program, mert barátokat szerezhetnek maguknak, hanem az elöítéletes magatartás pozitív befolyásolásában is szerepet játszik.

„Az egészséges gyerekek egyböl elfogadták a sérült gyerekeket és nem húzódoztak tölük, hanem közösen játszottak. Jó példa erre Danika négykerekes járókája, amit mindenki szívesen kipróbált volna, Danikát tolták benne és igy majdnem egész nap csak vele voltak.” A.D.

A szülők is pozitív visszajelzésekkel illeték a program szervezőit és tudták azt, hogy ha elhozzák erre a rendezvényre a gyerekeiket, akkor biztonságban tudhatják öket. A szülök azt is elmondták a szervezőknek, hogy a közös beszélgetések során, a pszihológus jelenlétében, végre fel tudtak engedni és meg tudtak nyílni. Sok mindent kaptak, elsősorban bátorítást, nagyon jó tapasztalatcsere-lehetőség volt számukra.

A nap elején Wagner Andrea programszervező bemutatta a szociális munkát hallgató önkénteseknek a programban résztvevő sérült gyermekekkel való speciális bánásmód sajátosságait. Ekkor a hallgatók eldönthették, hogy egy sajátos szükségletü gyermek „őrangyalai” szeretnének-e lenni a program folyamán, vagy inkább több gyermekkel foglalkoznának.

A különböző foglalkozásokat más-és más színekkel jelölték a programot leíró plakáton. Így ennek jegyében a gyerekek kékkel, zölddel és pirossal jelzett csoportokra oszlottak s így a csoportok mindig tudták, most éppen melyik teremben folyik a számukra kijelölt program: A kápolnában a gyerekek közösen zenélnek egy pedagógus vezetésével, különböző ritmusgyakorlatokat végeztek, valamint hangszerekkel játszottak. A konyhában mézeskalácsot készítenek, az önkéntesek segítségével. Minden gyerek maga formázza és díszíti saját mézeskalácsát. A pincében végignézhetik a Süntestvérek meséjét, vagy a Betlehemest bábokkal és árnyjátékkal előadva. Ebéd előtt megérkezik Piros bohóc, 
aki lufiból készít nekik figurákat. A gyerekek játékos mozgásgyakorlatokat végeznek, és egy akadálypályán is áthaladnak. A fogyatékos gyerekek ,őrangyalaik” segítségével oldják meg a feladatot. A közös ebéd után pihenésként rajzfilmvetítés van, ezt játékos, ökumenikus istentisztelet követi a kápolnában.

A program végén kiértékelésen vettek részt az önkéntesek, ahol egy kérdőívet kellett kitölteniük. A kiértékelő lap kérdései között megtalálhatták a következöket is: Mi motivált arra, hogy önkéntesként részt vegyél a programban? Melyek voltak az elvárásaid a programmal kapcsolatban? Mennyire felelt meg a program kivitelezése az elvárásaidnak? Szakmai szempontból mit tanultál a mai programból? Le kellett írniuk a nap legpozitívabb és legnegatívabb élményét is, és értékelniük saját munkáikat.

Lehetőségünk volt ezekbe a kérdöívekbe belenézni és egy hasonlóságot véltünk felfedezni: a program mindenki számára felejthetetlen élményt nyújtott. Szeretettel gondolnak vissza azokra a percekre amelyeket a gyermekekkel tölthettek el.

„Bár fárasztó volt maga a nap, minden nehézséggel együtt nagyon áldásos is. Sokat tanultunk a gyermekektöl, legföképpen türelmet és toleranciát és azt, hogy ha mi is úgy látnánk a világot ahogy ök, akkor rájönnénk: mindenkinek meghatározott helye van benne.” E.T.

\section{Befejező gondolatok}

A hátrányos helyzetü, kirekesztett, társadalmi kockázatnak kitett egyének, családok és közösségek oktatási és továbbtanulási, szakmai és társadalmi mobilitási folyamatai, illetve esélyei olyan sajátos jelenségkomplexumot képeznek, amely állandó, rendszeres és stratégiai tervezésen alapuló beavatkozást és figyelmet igényel. Az inklúziós gondolat lényeges minőségi többlete éppen abban áll, hogy a kultúrák egyenlőségén és egyenlő méltóságán alapuló befogadó társadalmi környezet kiakakítására törekszik. A képzés során éppen ezért törekednünk kell arra, hogy a hallgatók - tanulmányi feladatként végzett helyzetfelmérö kutatómunkájuk és gyakorlati terepmunkájuk során - a társadalmi kirekesztettség, marginalitás jelenkori problematikájához kötődve e problémák sokoldalú elemzésén, feltárásán keresztül, az esélyegyenlőség centrális célkitűzéséhez kötődő szellemiség jegyében keressenek érték- 
elvű megoldásokat, inklúziós többletet hordozó, esélyteremtő- és növelő cselekvési stratégiákat.

A társadalmi kirekesztettség problémáinak kutatása-feltárása, valamint a megoldáskeresés, a javaslatok megfogalmazása során hallgatóink szükségszerüen kapcsolatba lépnek az adott probléma megoldásában érintett/érdekelt személyekkel. Igy ismerik, tapasztalják meg, hogy az inkluzív politikák és társadalmi gyakorlatok alkalmazása során mit jelent a „hálózati” szemléletmód, amely a nevelési környezet kulcsszereplőit, szolgáltatásait és intézményeit (szülők, pedagógusok, iskolai és iskolán kívüli, pedagógiai és nem-pedagógiai jellegü szolgáltatások, az oktatási, foglalkoztatási és szociális szféra intézményrendszerei, jogi kerete és közpolitikai programjai, a célcsoportot alkotó közösségek saját, vagy sajátként értékelt intézményei, belső élete, kulturális jellemzői) a maguk egységében és kölcsönhatásában fogja fel és veszi tekintetbe.

Tudatosítanunk kell a hallgatókban azt is, hogy a szociális munkára jellemző beavatkozási folyamatban nélkülözhetetlenek a szakemberek, és hogy az egyetemei éveik során végzett kutató-értékelö-közpolitikai tervező aktivitásuk nem pusztán a vizsgakövetelmények által elöírt kötelezettség, hanem jóval több ennél: szakmai szereptanulás. A felkészülést jelenti azokra a feladatokra, amelyekre jellemző a bonyolultság, sokrétüség, a velük járó felelősség, de ezzel együtt a szociális hivatás szépsége, nemessége is. S mindez fokozatosan, e célirányos tevékenységekben való elmélyülés során kezd mindinkább megvilágosodni számukra, mint eljövendő szakemberek előtt.

\section{Irodalom}

AINSCOW. M. (1995): Special Needs through School Improvement; School Improvement through Special Needs. In: Clark et al (Eds.) Toward Inclusive Schools? Fulton - London.

BELÉNYI E. (2012): A szociális munkás képzés terepgyakorlata a Partiumi Keresztény Egyetemen, In. Terepmunka - terepgyakorlat a szociálpedagógus és a szociális munkás képzésben. Belvedere Meridionale, Szeged.

Blau J. (2010): In Pursuit of Equality of Rights, Dignity for All, Deep Democracy, \& Solidarities. http://www.sociologistswithoutborders.org/index.html (Letöltve, 2010. jún. 21.) 
BOHRNSTEDT G.W. (1969): Observations on the measurement of change.

Sociological Methodology Borgetta EF (ed), Jossey-Bass, San Francisco, 1969.

Bourdieu, P. (1969): Les héritiers, Jean-Claude Passeron, Minuit.

BOURKE, P. (2010): Inclusive education reform in Queensland: implications for policy and practice. International Journal of Inclusive Education; Mar2010, Vol. 14 Issue 2, p183-193

Castells, M. (2004): The Network Society: A Cross-Cultural Perspective. Cheltenham, UK; Northampton, MA, Edward Edgar

Coleman, J.S. (1964): Models of change and response uncertainty, Prentice-Hall, Englewood Cliffs.

Council of Europe (1998): Reccomendation 1355 Fighting social exclusion and strengthening social cohesion in Europe. Reply from the Committee of Ministers adopted at the 652nd meeting of the Ministers' Deputies (15 December 1998) http://assembly.coe.int/Mainf.asp?link=/Documents/WorkingDocs/Doc98/EDOC8 290.htm (Letöltve: 2010. jún. 23.)

Council of the European Union (2003): Council Resolution of 5 May 2003 on equal opportunities for pupils and students with disabilities in education and training (2003/C/134/04).

http://www.ozida.gov.tr/raporlar/uluslararasi/ab/ABmuktesebati/2003equalopport unitiespupilsandstudents.pdf (Letöltve: 2010. jún. 22.)

CSÁNYI Y. - PERLUSZ A. (2001): Integrált nevelés - inkluzív iskola/in. Báthory Z. Falus I. (szerk.): Tanulmányok a neveléstudomány köréböl 2001. Osiris Kiadó Bp. 2001. 314-332. p./

European Commission (1996): Communication of the European Commission on equality of opportunity for people with disabilities

http://ec.europa.eu/employment_social/socprot/disable/com406/index_en.htm (Letöltve: 2009. január 10.)

European Commission (2000): Towards a barrier-free Europe for People with Disabilities. Communication from the Commission adopted on 12 May 2000. $\operatorname{COM}(2000) 284$ final

European Commission (2010): Európai fogyatékosságügyi stratégia 2010-2020: megújított elkötelezettség az akadálymentes Európa megvalósítása iránt. http://eurlex.europa.eu/LexUriServ/LexUriServ.do?uri=COM:2010:0636:FIN:HU:HTML (Letöltve 2011.12.01.)

FERGE Zs. (2000): Elszabaduló egyenlötlenségek, Hilscher Rezső Szociálpolitikai Egyesület, Budapest

FERGE Zs. (2002): Kétsebességü Magyarország http://www.szmm.gov.hu/download.php?ctag=download\&docID=118...0 (Letöltve : 2010. jún. 22.) 
FÓNAI M. - PÁSZTOR E. - ZOLNAI E. (2007): A fogyatékos emberek helyzete, életmódja és életkörülményei Hajdú-Bihar megyében. Esély 2007/6, 87-119.p.

HALÁSz G. (2004): A sajátos nevelési igényü gyermekek oktatása: európai politikák és hazai kihívások Új Pedagógiai Szemle, 2004/02

HALl, J. (1992): Segregation by another name? Special Children, 4. sz. 20-23

HeGARTY. S. (1993): Reviewing the Literature on Integration. European Journal of Special Needs Education. 3. sz. 194-200.

InGSTAD B and Whyte R. S., ed. (1995): Disability and Culture. University of California Press, Berkeley and California

KozMA - ToMASz (2000): Előszó In: Kozma Tamás - Tomasz Gábor (szerk.) Szociálpedagógia. Osiris Kiadó, Educatio Kiadó, Budapest.

LALUVEIN, J. (2010): School inclusion and the 'community of practice' International Journal of Inclusive Education; Feb2010, Vol. 14 Issue 1, p35-48

MCLEAN M.A. (2008): Teaching about disability: an ethical responsibility? International Journal of Inclusive Education; Sep-Nov 2008, Vol. 12 Issue 5/6, pp. 605-619

Miller, S. M., M. ReIn, P. Roby, B. Gross (1967): Poverty, Inequality and Conflict, The Annals, 373, September 1967, pp. 16-52.

RADÓ Péter (2001): Esélyegyenlőség és iskolapolitika. Új Pedagógiai Szemle, 2001/01. http://www.oki.hu/oldal.php?tipus=cikk\&kod=2000-01-ei-RadoEselyegyenloseg (Letöltve: 2009. május 26.)

REICHER, Hannelore (2010): Building inclusive education on social and emotional learning: challenges and perspectives - a review International Journal of Inclusive Education; May2010, Vol. 14 Issue 3, p213-246

Salamancai Nyilatkozat és Cselekvési Tervezet (1994) http://www.barczi.hu/letoltesek/tudomanyos_testuletek/dokumentumok/SALAMA NCAMagyar.pdf (Letöltve 2010. december 15.)

SCHIFFER Csilla (2008): Az inklúzió fogalmának értelmezései és azok ellentmondásai In: Bánfalvy Csaba (szerk). Az integrációs cunami: tanulmányok a fogyatékos emberek iskolai és társadalmi integrációjáról. ELTE BGGYFK, ELTE Eötvös Kiadó, Budapest, 2008 pp. 45- 63)

SEBBA. J. (1996): Developing Inclusive Schools (Budapesten elhangzott előadás kézirata).

SLEE, Roger (2007): Inclusive education as a means and end of education? In: Florian Lani: The Sage Handbook of Special Education. SAGE, London -Thousand Oaks, New Delhi, 2007, pp. 160-173.

SzIRA Judit (2005): Gondolatok az integráció nemzetközi gyakorlatáról http://www.oki.hu/oldal.php?tipus=cikk\&kod=3I-Szira (Letöltve: 2009. január 20.) 
SWAIN J. and FRENCH S. (2004): Whose Tragedy: Towards a personal non-tragedy view of disability. In Swain J., French S., Barnes and Thomas (eds.) Disabling Barriers - Enabling Environments. (2nd ed.) Sage. London)

TORGYIK Judit (2004): Hatékony iskola: együttmüködő iskola. Új Pedagógiai Szemle, 4/2004, 26-38

TETLER, Susan (2006): Inkluzív osztályok : a tanítás és tanulás modelljei, dilemmák és kihívások Iskolakultúra, 16. 10. 36-42.p

WRIGHT, Kevin (2010): 'Count us in' - achieving inclusion in Scottish schools: an analysis of policy. International Journal of Inclusive Education; Mar2010, Vol. 14 Issue 2, p153-164 


\title{
Sárkány Péter ${ }^{3}$
}

\section{AZ ELMÉLET GYAKORLATA SZAKMAI HITELESSÉG ÉS ELMÉLETI \\ OKTATÁS}

\author{
THE PRACTICE OF THEORY \\ PROFESSIONAL AUTHENTICITY \\ AND THEORETICAL TEACHING
}

\begin{abstract}
My study raises questions regarding specific relation between professional authenticity and practice of theoretical teaching in social work education. By interpretation of the relating topical literature in German I explore the actual theories of professionalism.
\end{abstract}

\section{A szakmai hitelesség meghatározásának nehézségei}

Ha nem egy konkrét szakember hitelességéről, hanem egy egész tudományterület és szakmai gyakorlat hitelességéről beszélünk akkor érdemes azokat az általános hiányosságokat kiemelni, amelyek megnehezítik a szakmai hitelesség meghatározását és az elméleti oktatás sikerességét.

a.) Az egyik lényeges hiányosság a szociális szakmák késői önállósodásával magyarázható. Az önálló szociálpedagógia/szociális munka mint szakma, tudomány és képzés a huszadik század első felétől alakul ki fokozatosan. Ráadásul Kelet-Közép Európában csak a rendszerváltozás tette lehetővé a szociális segítőszakmák tudományos szempontokat is figyelembe vevő müvelését. ${ }^{4}$ Magától értetődő, hogy egy ilyen későn kialakuló alkalmazott tudomány hitelesség-problémával küzd, föleg ha

\footnotetext{
${ }^{3}$ Dr. Sárkány Péter PhD, főiskolai tanár, Apor Vilmos Katolikus Főiskola Társadalomtudományi és Romológiai Tanszék

${ }^{4}$ A szociális munka professzionalizációjához lásd: Kozma 2007
} 
ezeket a szakmákat a már nagy múlttal rendelkező foglalkozásokhoz hasonlítjuk. Gondoljunk itt elsősorban a papnak, az orvosnak, a jogásznak, a pszichológusnak vagy akár a pedagógusnak a társadalom által biztosított szakmai hitelességére. Önmagában ezeknek a képzéseknek az elvégzése már megelőlegezi a szakmai hitelességet. A társadalom jelentős része pozitívan ítéli meg az említett szakmákat, még mielőtt a konkrét szakember viszonyulása szóba kerülne. Ebböl a szempontból megállapítható, hogy a szociálpedagógia és a szociális munka még mindig tekintély-deficittel küzd, hiszen a szociálpedagógus és a szociális munkás tevékenységével kapcsolatban még meglehetősen sok negatív elöítélet és az ismeretek hiányával magyarázható tájékozatlanság tapasztalható.

b.) Az előző szemponttal szoros összefüggésben egy másik aspektus is befolyásolja a szociális munka hitelességét, nevezetesen az, hogy ennek a szakmának a müvelésében és főleg a képzésében még mindig elég nagy számban rokon, de mégis eltérő logikájú diszciplínák és szakmák bábáskodnak. Gondolok itt elsősorban az orvostudományra, a pedagógiára, a pszichológiára vagy a teológiára. Több képzési programban megfigyelhető például a pedagógiai vagy a pszichológiai megközelítések túlsúlya. Ebböl következik, hogy a szociális szakma tudományos és szakmai szempontból még mindig komoly autonómia-deficittel küzd.

c.) A tekintély-deficit és az autonómia deficit mellett, egy harmadik tényező még erőteljesebben befolyásolja a szociális szakmák hitelességét. Ezek azok az elméletek, amelyek a különböző szakmák sajátosságait írják le. Ebböl a szempontból megállapítható, hogy a különféle tankönyvek meglehetősen sokszínüen mutatják be a szociálpedagógia és szociális munka szakmaiságát, mivel a szakirodalomban számos szakmaszociológiai paradigma érvényesül (Vö.: Kurtz 2008). Az egyik leggyakoribb szemlélet az úgynevezett tulajdonságközpontú elmélet, amely a klasszikus szakmák fontosabb tulajdonságait rögzíti és ennek alapján dönt arról, hogy egy kérdéses szakma milyen mértékben tekinthető igazi vagy ha úgy tetszik ,hiteles” szakmának (Knoll 2010). Mint köztudott ezzel a megközelítéssel az a probléma, hogy a szociálpedagógia/szociális munka szakmaiságán ugyanazon kritériumrendszert kéri számon, mint amelyek a klasszikus szakmákat (orvos, jogász vagy pedagógus) jellemzik. A másik két ismert szakmaszociológiai irányzat a funkcionális és a hatalomközpontú megközelítés. Az első a szakmaiságot a világosan elkülöníthető funkcióban látja, a második viszont egy szakma befolyására kérdez rá, és azt állítja, hogy a 
szakmaiság legfontosabb mércéje ennek a befolyásnak a mértéke (Knoll 2010). Ha kizárólag az említett szakmaelméletek elvárásainak kívánunk megfelelni az oktatás során, akkor magunk is hozzájárulunk a szociális szakmák hitelvesztéséhez. A szociálpedagógia vagy a szociális munka ugyanis a klasszikus szakmák alapján kiemelt jellemzőknek nem tud megfelelni (Vö.: Schütze 1992). A pontosan körülhatárolható funkció és a jelentős társadalmi befolyás kívánalma is igen csekély mértékben tud megvalósulni. Ezt ráadásul a szociális szakmáról kialakult különböző negatív elöítéletek felerősítik. Ilyen például az az elöítélet, miszerint a szociális munka az orvostudományhoz vagy a pszichológiához képest a kevésbé súlyos problémákat kezeli. Ráadásul ezt az elöítéletet a szociális szakemberek alacsonyabb kereseti lehetősége is felerösíti (Vö.: Galuske 2003, 133-144).

A fent vázolt deficiteket figyelembe véve meggyőződésem, hogy a szakmai hitelesség helyes értelmezése érdekében és a nemzetközi trendekkel összhangban, a magyarországi oktatásban is inkább azokat a szakmaelméleteket kellene figyelembe venni, amelyek nem tulajdonságkritériumok, funkciók vagy a hatalom birtoklásának nézőpontjai alapján tájékozódnak, hanem a szociális szakmára jellemző cselekvési struktúrát vagy a szociális munka rendszerét elemzik. Tehát azt állítom, hogy a szociálpedagógia és szociális munka elméleti oktatásának gyakorlata során, elsősorban ezekből a szakmaelméletekböl kellene kiindulni. A szakmaelméletek ugyanis összekötik a szociálpedagógia és szociális munka gyakorlatát az akadémiai igényü diszciplináris eleméletekkel. Vagyis a szakmai identitásra és hitelességre törekvő oktatás akkor lehet eredményes, ha a diszciplína és a praxis összefüggését a szociális professzió jellemzői felől közelíti meg. Ennek alapján dolgozza ki nemcsak a gyakorlati, hanem az elméleti oktatás követelményeit is.

\section{Kortárs szakmaelméletek}

Állításom alátámasztása érdekében a továbbiakban röviden három kortárs szakmaelméletet mutatok be. Mindhárom elméletet azonos szempontok alapján vázolom. Először a szakmáról megfogalmazott fontosabb állításaikat rekonstruálom, majd ezeket összefüggésbe hozom az általuk képviselt tudományelméleti és módszertani háttérrel. ${ }^{5}$

\footnotetext{
${ }^{5}$ A kortárs szakmaelméletek részletesebb értékeléséhez és elemezéséhez lásd: Sárkány 2013
} 


\section{a.) Nyitott szakma (Hermeneutikai elmélet)}

A szociálpedagógia kiemelkedő képviselője, Burkhard Müller a szociális szakmák alapvető jellemzőit meghatározott képességekhez köti. Ilyenek a nyitottság, a gyakorlati területek problémáiba és a kliensek életvilágába való elmélyülés képessége valamint a szakember sajátos személyes etikai tartása (Müller 2012, 955-972). A szociálpedagógia szakmaisága szerinte sajátos formát ölt, hiszen olyan kérdésekkel és problémákkal foglalkozik, amelyeket nem alakít át szakkérdésekké. Ezért a szociálpedagógia szerinte nyitott szakma. Szakmaiságát az alábbi fogalmak írják körül: életvilág-irányultság, participáció vagy éppen a képessé tétel (uo.). Ezek a célok nehezen összeegyeztethetők a szakértő szerepével, mivel a szociálpedagógiában/szociális munkában nem lehet zárójelezni a kliens hétköznapi problémáit, nem lehet a kliens akarata ellen vagy intézményektöl függetlenül cselekedni (uo., 966). Ezért Müller érvelése szerint szakmaelméleti szempontból a legfontosabb kérdés, hogy a „szociális munka tudása” hogyan határozható meg. A szociális szakmák szerinte „,szerény szakmák”, mert számos első megközelítésben egymásnak ellentmondó - tényező között kell az egyensúlyt megtalálni (uo. 966). Ilyen helyzetek például a problémák elemzésének és koncepciók kidolgozásának feladata, anélkül, hogy szem elől tévesztenénk az egyes ember egyszeriségét; Az egész ember életösszefüggését kell figyelembe venni, miközben a soron következő apró lépésekre is koncentrálni kell; Krízis szituációkat kell kezelni úgy, hogy a kliens döntési szabadsága ne sérüljön, és így tovább. (uo. 967). Az így vázolt nyitott és szerény szakma két fontos feltevésen nyugszik. 1.) A szociális szakmák alapvető kérdése az életvilágra, a megküzdési feladatokra és a társadalmi problémákra vonatkozik (Müller 2006, 1819). A tudományos vizsgálódás ezeket leírja, majd a szakmai gyakorlat és a bennük rejlő erőforrásokat feltárja. 2.) A másik fontos feltevés szerint pedig a szociális munka mindenekelőtt kapcsolati munka. Ezért ezen a szinten a tudománynak értelmezési feladata van (uo. 9).

A fentiekből kitünik, hogy Müller megközelítése a hermeneutikai hagyomány, a fenomenológiai paradigma és a különböző hétköznapelméletek belátásain nyugszik.

Számára a szociálpedagógia nem más, mint a szociálpedagógiai esetek értelmezése. Müller egyenesen az „esetmegértés müvészetéről” beszél. Szakmai szempontból létfontosságú, hogy mit nevezünk szociálpedagógiai esetnek. A szakember elsőrendủ feladata, hogy egy elbe- 
szélt történetet szociálpedagógiai szempontból értelmezzen (Müller 2006).

\section{b.) Emberjogi szakma (rendszerszemléletü megközelítés)}

A szociális munka egyik kiemelkedő teoretikusa, Silvia StaubBernasconi szerint a szociális munka csak akkor válhat komoly tudománnyá és szakmává, ha a saját úgynevezett harmadik mandátumát is figyelembe veszi. Ez a harmadik mandátum pedig nem más, hangsúlyozza jelentőségteljesen, mint a szociális munka tudományosmódszertani és etikai alapjai (Staub-Bernasconi 2007). Egy önálló szakma meghatározott tudományos bázison és etikai elveken nyugszik. Felfogása szerint ez a két elem a szakszerű szociális munka lehetőségi feltétele. A szociális munka etikai alapja pedig egy a szakma által meghatározott és kötelező érvénnyel bíró etikai kódex. Mindez azt jelenti, hogy a kettős mandátumból fakadó konkrét dilemmák (segítés versus kontroll) feloldása során a szociális munkásnak erre a harmadik mandátumra kell támaszkodnia. Staub-Bernasconi a szakmai etikai kódexen kívül az általános etikai megalapozás érdekében az emberi jogokra hivatkozik. „Az emberi méltóság alapeszméjének és az emberi jogoknak a bevezetése az oktatási tervekbe, a képzésbe és a gyakorlatba, annak minden filozófiai, vallási, elméleti, gyakorlati és tapasztalati következményeivel együtt egy olyan pillér lenne, függetlenül a társadalmi nyomástól és idegen megfogalmazásoktól, amely etikai ítéletek és egyértelmü feladatok megfogalmazását tenné lehetővé" (Staub-Bernasconi 2006, 287; fordítás tőlem - S.P). Mindennek alapján a szociális munkát mint emberjogi szakmát határozza meg. Ez a szakmafelfogás nála szervesen illeszkedik a szociális munka rendszerszemléletébe. A rendszerszemlélet az egyén és a társadalom kapcsolatának komplex elmélete, amely kimondja, hogy „minden ami létezik vagy egy rendszer vagy egy rendszer része“(uo., 270). Így a szociális problémák valójában az egyén és a szociális rendszer interakcióinak a problémái (uo. 270). Ebből kifolyólag egyetlen szociális probléma sem magyarázható kizárólag egy diszciplína keretén belül. Biológiai, pszichikai, szociológiai, kulturális, környezetvédelmi stb. okok egyaránt hozzájárulhatnak a szociális problémák kialakulásához. Staub-Bernasconi felfogásában tehát a szociális munka egy sajátos rendszer, amelynek elsőrendü feladata a különböző rendszerek közötti közvetítés oly módon, hogy az emberi jogok kibontakoztatását elősegítse. ${ }^{6}$

\footnotetext{
${ }^{6}$ Staub-Bernasconi megközelítésnek etikai vonatkozásaihoz lásd: Sárkány 2011
} 


\section{c.) Identitásnélküli szakma (posztmodern elmélet)}

Heiko Kleve szerint a szociális munka identitása, a mai kor kihívásainak megfelelöen, posztmodern identitásnak tekinthetö. Többszörös identitásról van szó, amely szembehelyezhető a modern identitás egyértelmüségre, egységességre és ellentmondás-nélküliségre való törekvésével. Ennek megfelelően határozható meg a szociális munka mint diszciplína és szakma. „A szociális munka egy (világos, egyértelmü, tartós és ellentmondásmentes) identitást nélkülöző szakma és diszciplína, identitása inkább az identitásnélküliség."(Kleve 2000, 13; fordítás tőlem - S.P.). Kétségtelen, hogy ez a meghatározás első megközelítésben elég ellentmondásosnak tünik, hiszen éppen attól nevezünk valamit szakmának és/vagy diszciplínának, mert jellemzői világosan körvonalazhatók, s ezáltal más szakmáktól és diszciplínáktól jól elkülöníthetők. Kleve a szociálismunka-szakma sajátosságainak leírására a posztmodern filozófia módszerét, a dekonstrukciót veszi igénybe. A posztmodern gondolkodók, mint például Jacques Derrida éppen a nem egyértelmü, paradox és ellentmondásos összefüggéseket elemzik és azt a feladatot tüzik ki célul, hogy a látszólag egyértelmủ elméletek következetlenségeire és ellentmondásaira rávilágítsanak. Ennek megfelelően a posztmodern szociális munka is egyfajta dekonstrukciós praxisnak tekinthetö, amely a modernitás ambivalenciáinak feltárást végzi el (Kleve 2000, 89). Kleve érvelése szerint ugyanis a szociális munka kialakulása a modernitás krízisének köszönhető, hiszen ez a szakma a modernitás irracionális, a családi életvilágok szétesésének következményeként elöálló kiszámíthatatlan problémákat vállalja fel (uo. 87-88).

A dekontrukciós módszer Kleve gondolatmenetében rámutat arra, hogy miért jár tévúton a szociális munka mint szakma, ha a modern identitás kritériumait követi és az ellentmondások és paradoxonok teljes feloldására törekszik. A szociális munka, hangsúlyozza jelentőségteljesen Kleve, ambivalens szakma (Kleve 2007, 33). Ennek megfelelöen a dekonstrukciós módszer valójában nem más, mint a szociális munka ambivalenciáira irányuló reflexió. A modernitás szakmafelfogása három fontos jellemzőt várt el egy szakmától: 1.) Szaktudományos tudást produkáljon; 2.) Szakmai és etikai értelemben vett autonómiával bírjon; 3.) Legyen egyértelmü társadalmi felhatalmazása. Ezeknek a kritériumoknak viszont a szociális munka nem tud megfelelni, mert közvetítő szerepet tölt be és ambivalenciákkal kell megküzdenie (Kleve 2000, 90-91). A szociális munka nem rendelkezik egyértelmü társa- 
dalmi mandátummal, ráadásul szakmai tudása sem korlátozódik egyetlen területre. Számos más tudományágat előfeltételező tevékenységről van szó. Ennek köszönhetően a szociális munka nem rendelhető hozzá a társadalom egyetlen funkcionális rendszeréhez sem. Kleve szerint a szociális munka az életvilágok, társadalmi rendszerek és különböző szakmák között közvetít. Nézőpontja: bio-pszicho-szociális. A klasszikus szakmákhoz viszonyítva, amelyek kizárólag a saját diszciplinájuk határain belül mozognak, a szociális munkának mint szakmának a diszciplínáris háttere és müködési területe meglehetősen heterogén (uo.).

Kleve felfogásának összefoglalásaként megállapítható, hogy a szociális munka heterogenitásának, a sokféle kihívásnak való megfelelés követelményének a posztmodern tudományelméleti és módszertani háttér felel meg.

\section{Összefoglalás és következtetések}

Az általam bemutatott első szakmaelmélet önmagát nyitott vagy szerény elméletnek nevezte, hiszen a esetmegértés hermeneutikai hagyományát követi és azt állítja, hogy egyszer és mindenkorra nem rögzíthetők a szakmaiság kritériumai. A szakmai hitelesség nem az objektív elvekhez való ragaszkodásban, hanem szintén a hermeneutikai módszer segítségével értelmezhető szakmai készségek tudatosításában és elsajátításában nyilvánul meg. A praxis individuális színezetü problémák elé állítja a szakembert, aki a korábban begyakorolt képességei révén az adott eset elemzésére és a hatékony segítés kivitelezésére törekszik. Éppen ezért Burkhard Müller meglehetősen szkeptikus az átfogó és objektivitásra törekvő szociálismunka elméletekkel szemben.

Első megközelítésben Müller hermeneutikai elméletével szembe áll, Staub-Bernaconi megközelítése, aki a tudományos alapokat és az etikai elveket kéri számon a szociális munkától. Ha azonban közelebbről szemügyre vesszük érvelését kiderül, hogy a szakmai hitelességet oly módon köti az emberi jogok által megtestesített értékekhez, ami a legtöbb tudománytól meglehetősen idegen. Ezeknek az értékeknek a felvállalása és érvényesítése nála a szakmai hitelesség egyik fontos kritériuma. Ehhez jön még a szociális munka rendszerszemléletủ megközelítésének a képviselete. Ebben a szemléletben az egyéni szabadság és a társadalmi igazságosság ugyanolyan mértékben játszik szerepet. Tehát 
a hiteles szociális munka Staub-Bernasconi szerint értékközpontú és rendszerszemléletü, amely egyben azt is jelenti, hogy a szociális problémák nem magyarázhatók kizárólag egyetlen diszciplína keretén belül.

Végül Heiko Kleve írásaiban a szociális munka posztmodern szakmaként értelmeződik. A szociális munka állandó szakmai identitásválságát nem negatívumként, hanem a szociális munka gyakorlatának megfelelően, pozitívumnak kezeli. Gondolatmenetéből egyenesen következik, hogy a hiteles szociális munka felvállalja a modernitás kihívásait és önmaga tekintetében is szembe néz az ambivalenciákkal és az ellentmondásokkal. A posztmodern szociális munka a hitelesség nevében igényli a pluralitást, az életvilágok sokféleségének jogosságát és az antitotalitárius viszonyulást.

A három szakmaelmélet rövid összegzéséből kiderül, hogy ezek az elméletek számos ponton különböznek, de ugyanakkor mégis hasonló következtetésekre jutnak. Mindebböl a szakmai hitelesség és az elméleti oktatás vonatkozásában legalább három fontos következtetés fogalmazható meg:

(1) A szociális munka akkor hiteles, ha nem a fehér köpeny által szimbolizált orvosi tekintély mércéje alapján tájékozódik, de a pszichológiai munka módszertani redukcióját és a pedagógiai viszonyt sem tekintheti a szakmai hitelesség forrásának. A fent említett szakmaelméletek mindegyikében, sajátos a szociális munka gyakorlati kihívásainak megfelelö viszonyulást kell kialakítania, s fel kell vállalnia azokat a bizonytalanságokat, amelyek a klasszikus tudomány- és szakmaideál szempontjából nem kívánatosak. Tehát nem akkor hiteles a szociális munka és az ehhez kapcsolódó elméleti oktatás, ha egy absztrakt tudomány és idegen szakmaeszmét követ, hanem ha a szociális problémák jellemzőire összpontosít.

(2) A hiteles szociális munka tehát elméleteit, módszereit, beavatkozási koncepcióit

a szociális problémák sajátosságaihoz igazítja. Ez azt is jelenti, hogy az esetkezelést,

a csoport- és közösségi munkát nem helyezi el a különféle diszciplínák Prókusztész-ágyába. Az oktatásban ezért a hitelesség kritériummá válik a szociálpedagógia/szociális munka elméleteinek elkülönítése azoktól az elméletektől, amelyek általánosságban a szociális foglakozások funkcióiról szólnak vagy azoktól az elméletektől és módszerektől, amelyeket kiválóan lehet alkalmazni a szociális szakmában, de eredetileg 
más tudományos diszciplínák keretén belül dolgozták ki őket (Kleve/Wirth 2009).

(3) Végül a harmadik lényeges következtetés: Elméleti és gyakorlati szempontból azok a munkamódszerek hitelesek, amelyek képesek a hermeneutikai esetelemzést, az életvilág-irányultságot, a rendszerszemléletet és a konstruktivista-posztmodern törekvéseket integrálni. Ezért véleményem szerint az említett szakmaelméletek oktatásba történő bevonása az igényes szakmai identitás és hitelesség kialakításnak egyik legfontosabb eleme.

\section{Irodalom}

Galuske, M. (2003): Methoden der Sozialen Arbeit: Eine Einführung (5. Auflage). Weinheim und München, Juventa.

KLEVE, H. (2000): Die Sozialarbeit ohne Eigenschaften: Fragmente einer postmodernen Professions- und Wissenschaftstheorie Sozialer Arbeit. Freiburg i. Breisgau, Lambertus.

Kleve, H. (2007): Ambivalenz, System und Erfolg: Provokationen postmoderner Sozialarbeit. Heidelberg, Carl Auer.

Kleve, H./Wirth J. V. (2009): Die Praxis der Sozialarbeitswissenschaft: Eine Einführung. Baltmannsweiler, Schneider Verlag Hohengehren.

Knoll, A. (2010): Professionelle Soziale Arbeit: Professionstheorie zur Einführung und Auffrischung. Freiburg im Breisgau, Lambertus.

KozMA Judit (2007): A szociális munka professzionalizációja a jóléti államokban I. Kapocs, 29. szám, 2-19. old.

KurTz, T. (2008): Die Berufsform der Gesellschaft. Weilerswist, Velbrück Wissenschaft.

MÜLlER, B. (2006): Sozialpädagogisches Können: Ein Lehrbuch zur multiperspektivische Fallarbeit (4. Auflage). Freiburg im Breisgau, Lambertus.

Müller, B. (2012): Professionalität. In: Thole, W. (Hrsg): Grundriss Soziale Arbeit: Ein einführendes Handbuch (4. Auflage). Wiesbaden, Verlag für Sozialwissenschaften 955-974.

SÁRKÁNY P. (2011): A szociális munka mint alkalmazott etika. Szociális Szemle IV. (2011/1-2), 7-18.

SÁRKÁNy P. (2013): Theorie und Praxis Sozialer Arbeit. Eine professionstheoretische Auseinandersetzung. Marburg, Tectum. 
SCHÜTZE, F. (1992): Sozialarbeit als „bescheidene” Profession. In: Dewe, B./Ferchoff, W./Radtke, F.-O. (Hrsg.): Erziehen als profession. Zur Logik professionellen Handelns in pädagogischen Feldern. Opladen, S. 275-454

StAUB-BERNASCONI， S. (2006): Der Beitrag einer systemischen Ethik zur Bestimmung von Menschenwürde und Menschenrechten in der Sozialen Arbeit. In: Dungs, S./Gerber, U./Schmidt, H./Zitt, R. (Hrsg.): Soziale Arbeit und Ethik im 21. Jahrhundert: Ein Handbuch. Leipzig, Evangelische Verlagsanstalt, 267-268.

Staub-Bernasconi, S. (2007): Dienstleistung oder Menschenrechtsprofession? Zum Selbsverständnis Sozialer Arbeit in Deutschland mit einem Seitenblick auf die internationale Diskussionslandschaft. In: Lob-Hüdepohl, A./Lesch, W. (Hrsg.): Ethik Sozialer Arbeit: Ein Handbuch. Padeborn, München-Wien-Zürich, Ferdinand Schöningh, 20-54. 


\title{
Mojzesné dr. Székely Katalin ${ }^{7}$
}

\section{„RENDEZNI VÉGRE KÖZÖS DOLGAINKAT" - TÁJÉKOZÓDÁS A VILÁGBAN, ELIGAZODÁS A KÖRNYEZETBEN, ÖNISMERET}

\author{
„TO ARRANGE OUR COMMON ISSUES” - GATHERING IN- \\ FORMATION ABOUT THE WORLD, ORIENTATION IN THE ENVI- \\ RONMENT, SELF-KNOWLEDGE
}

\begin{abstract}
According to the statement of the author there is no social co-existence without building connections. That is why she thinks that it is worthwhile to examine the main characteristics of verbal and non-verbal communication in connection with the interregional cooperation. The author highlighted two main elements: celebrations and donation as special features of our everyday life, both are important because they help us to endure the problems in everyday life.
\end{abstract}

\section{Bevezetés}

Vannak időszakok, amikor leértékelődnek a szavak. Talán Kodolányi beszélt erről 1943-ban a Szárszói konferencián. De Ortegától is tudjuk, ennek ellenére, milyen nagy az írástudók felelőssége, valamint minden felnőtté. Magam mindig is így éltem meg értelmiségi szerepemet, kutatói és tanári hivatásomat. De szülőként és nagyszülőként is felelősséget érzek a gyerekek, a fiatalok iránt. Ezért fogadtam örömmel, hogy részese lehetek egy olyan pályázatnak, amely egyetemistákról és nekik szól. Azokkal döntöttünk úgy, hogy gondolatainkat kötetbe foglaljuk, akikkel a most záródó HURO pályázatban részt vettünk

Egyszer amúgy is úgy érzi az ember, eljött az összegzés ideje. Az idő egyébként is elhanyagolt kérdés a generációknak átadott tanulságok

\footnotetext{
${ }^{7}$ Mojzesné dr. Székely Katalin egyetemi docens, Debreceni Egyetem, Bölcsészettudományi Kar
} 
között. Pedig alapvető annak tudatosítása, hogy jól éljünk vele/benne. Nem ismerjük a nekünk adott hosszát. Ráadásul a társadalom tagoltsága ebben is kifejeződik. Van, aki rendelkezik az idejével, van aki a másokéval is és van, aki a sajátjával sem. Arra érdemes szociológus szerint három időnk van: biológiai - ez a korunk, történelmi - milyen traumák értek minket életünk során, végül a társadalmi idő - melyik társadalmi rétegben éljük meg mindezt. (Losonczi, 2009) az idő súlyát az adja, hogy nem ismerjük a végét. Ehhez kell mérni lehetőségeinket. Borús bevezetőnek tünik, de reális problémáról van szó.

Aki hivatásában a társadalommal „bíbelődik” és szerepe van az ifjúság képzésében gondolkodásában eljut odáig, hogy a világ értelmezéséhez sarkkövek alakulnak ki benne. Ezek bármilyen téma megragadásakor kiindulópontot jelentenek és számomra is nagyon fontosak. Úgy érzem, erről szólni kell, mert tudom, hogy egy részük olyan szellemi közkincs - mondhatnánk közhely, már-már evidencia - amelynek eredete megfejthetetlen. Más részük felfogásunkból eredö életelv, vagy saját gondolat is, vagy azzá vált. Összegyüjtöttem a legfontosabbakat. Miután két kurzus programját dolgoztam ki és adtam elő a határ mindkét oldalán (itthon Hajdúböszörményben és Nagyváradon). Ehhez mértem a már említett szélesebb társadalmi összefüggéseket, a legfontosabbakat. Az egyik kurzus: A kultúra, hagyomány, magatartás... kérdéseit elemezte a határ két oldalán. A másik: Az önkéntes munka lehetősége, értéke... és ehhez kapcsolva az ifjúság és a politika kérdései.

Ezek a következők:

- A társadalom minősége a mindenkori felnőtt társadalom felelössége.

- A „simogatni az ifjúság fejét” gondolat, vagyis a legnagyobb kincsünk a gyermek és az ifjúság.

- Ahhoz, hogy egy társadalom müködőképes legyen, valamennyire meg kell szervezni. Ha túl szervezik, nem jó benne élni és diktatúrához vezet. Ha alulszervezik, nem lehet benne élni és anarchiához vezet. Ezért nagy az uralmon levők - és mindnyájunk - felelőssége.

- Az emberiség együttélésre van ,ítélve” és ez nem választás kérdése (globalizáció, európaiság).

- A társadalom a generációk folytonosságában újul meg.

- A kiszolgáltatottság és megalázottság nem méltó emberhez.

- Elengedhetetlen szükségletek: szolidaritás, biztonság/bizalom, egészség, melyek nálunk apadóban vannak. 


\section{Van közünk egymáshoz}

Nagy dilemma, mi az, amit a szociológus korlátozott terjedelemben elengedhetetlen tudásnak tekintsen, ha szabadon dönthet ebben. Ettől nagyobb felelösség az, hogy szemléletével milyen irányba mozdítja diákjai gondolkodását. Talán felmentést ad, ha hangsúlyt kap lezáratlan viták esetén azok ismertetése, személyesen pedig az érvelés és a szabad véleménynyilvánítás.

A társadalmat az érthetőség kedvéért bonyolult emberi viszonyok összességeként tekintettük. Végigtekintettünk az emberiség történetén és azt láttuk, hogy az ősi egyenlőséget leszámítva az összetartozó közösségek tagolódnak és három jellemzőjük van: a kialakult szerkezet állandósága, a benne elfoglalt helyek örökölhetősége és a hierarchia - a mai modern társadalmakban is. Az alá-fölé rendeltség, az egyenlőtlenség és a belőle fakadó hátrány megítélése máig le nem zárt vita tárgya. A javakhoz való viszony eltérései jól mutatják ennek indokoltságát. Magam, ha javakat mondok, anyagi, szellemi és hatalmi javakra gondolok. A leglátványosabb az anyagi javak hozzáférésének szakadéka - a luxus és a szegénység. A legérdekesebb a nemek közötti egyenlötlenség, ahol egy biológiai-fiziológiai különbség válik társadalmi hátránnyá a nők számára, évszázadokig. (Kaari Utrio, 1999) Vállalt feladatunk a tárgyalt téma miatt a demográfiai szerkezet másik dimenziója volt lényeges: a gyermek- és az ifjúkor. Térségünkben jelentős maradt a települési hátrány is.

Nem csak a történeti áttekintés, hanem a jelenbeli állapot is fontos. Meglátásom szerint segíti az érthetőséget az a megvilágítás, mely szerint:

- létezik a „fent” (nevezzük elitnek), ahol előnyök elönyökkel kapcsolódnak össze,

- van a „közép” csoport, itt elönyök hátrányokkal fonódnak egybe,

- végül „lent”-ről beszélhetünk, ahol hátrányok hátrányokkal szövetkeznek és öneröből nehéz, ha nem lehetetlen feljebb emelkedni.

Nyilvánvaló, hogy a modernizációban kialakult egyenlőtlen társadalmi fejlödés következtében a népek, társadalmak belső arányai változatosak a fentieket illetően. Ahhoz, hogy az ember tudatos polgárrá váljon, ennyi társadalomismeretet tudnia kell, bármi a státusa. De értelmiségi jelöltek esetében ettől árnyaltabb tudásra és határozottabb 
attitüdre gondolok. Megpróbáltam a korábbiakban végiggondolni, hogyan tipizálhatnám a társadalomismeretet. Amire jutottam:

a. Tájékozódás a világban, mely időbeli (múlt ismeret) elsősorban identitásunk miatt fontos és térbeli (másokkal együtt vagyunk a „térképen”) és így messzi nem is olyan messzi.

b. Eligazodás a környezetünkben, környezetnek tekintve minden kis közösséget, amelyhez tartozunk. Ezek közül ugyan kiemelkedik a család és az intézmények, de a spontán közösségek is fontosak.

c. Önismeret, mely kevéssé a szociológia, inkább a pszichológia tárgya, felségterülete, de nekünk is van mondanivalónk, hogy kudarcokat lehessen elkerülni és sikereket elérni ennek birtokában. .

Ha magasról nézzük, a társadalom, az életmód és a kultúra nagyjából lefedik egymást, de csak nagyjából mindhárom fogalom és valóság az egy közösséghez tartozók összességére vonatkozik. De míg a társadalom makrocsoportok árnyalt szerkezete, az életmód - mely éppen az előbbiek miatt rétegkötött - ennek a sokaságnak a szükségletkielégítését jelentő cselekvési és magatartási rendszer. Talán a kifejezés nem is elég korszerü, de beleette magát a magyar szakmai nyelvbe és eredményei is jelentősek. (Szalai, Szántó, Losonczi, Utasi stb.)

A kultúra a szociológiában és a társadalomtudományokban általában is sokféle értelmezést megért és ma is vitatják. Egyet azonban minden megközelítés elismer - a kultúra jelentőségét a társadalmak életében, a múlt és jelen kapcsolódásában, a fennmaradásunkban. Mannheimtől Braudelen át Eliasig, Hankisstől Vitányin át Gombárig. Sok nívós irodalmat tekint át a szakember és nem jut nyugvópontra, miközben több dimenzióban volna jó eligazodni.

Az egyik értelmezési kérdés a civilizáció és kultúra körül bontakozott ki. Anélkül, hogy elmélyednénk magas elméleti diskurzusokban, annyit le kellene írni, milyen irányzatok vannak. Az egyik a kettőt azonosnak, szinonimáknak tekinti. Mások a civilizációba bennfoglalják a kultúrát, ellenérvelők a kultúrába foglalják a civilizációt. Megint mások megkülönböztetik a kettőt, netán szembeállítják egymással. Vannak, akik elnevezésbeli problémát látnak benne vagy térségi különbségeket. 
Mindkettő vagy együtt a kettő is hozzájárult ahhoz, hogy a biológiai lény a szocializációban társadalmi lénnyé vált.

Magam a megértés végett és az analízis szintén a külön értelmezést vallom, amely lehet az én tévedésem. A civilizációt elsősorban egyetemes anyagi-technikai értéknek tekintem, amely az emberiség kényelmét szolgálja és fokozatai vannak (civilizálatlan, civilizált). Idő és pénz kérdése az elérés.

A kultúra (colere=müvelni) megítélésem szerint elsősorban szellem érték (nyelv, erkölcs, vallás, hit, hagyomány, müvészet, tudomány, irodalom stb.) és funkcióját tekintve integrál és fenntart egy közösséget és nincsenek fokozatai. Nem minőségében, hanem másságában van a különbözősége. Elöítéletes régiónkban ezt különösen fontos hangsúlyozni, ahol ráadásul kettős, sőt hármas identitást is megélnek az emberek. De nehezen viselik a többiek másságát. Ebben a határmenti régióban (magyar-román esetünkben) munkája során is érzékeli az ember. 22 éve óraadóként tanítok a Nagyváradi Partiumi Keresztény Egyetemen, de voltam óraadó tanár 15 évig Hajdúböszörményi Főiskolán is és munkahelyemen, a Kossuth Egyetemen is összegyültek 50 év alatt a tapasztalataim. Természetesen a gyakorlatban átfonja egymást a két fogalom, illetve az anyagi-technikai értékek is a szellem termékei és fordítva. A szellemet is fogva tartja a civilizáció.

Attól sem tekinthetünk el, hogy a kultúra szubkultúra is és ennek kezelése, napi társadalmi következményei, a velük való együttélés okán is vannak teendői az értelmiségnek és a politikának is. Ha kitágítjuk a vizsgálódást a globalizációval összefüggésben, már a 70-es években felvetődött a civilizáció-kultúra globalizációs, nemzeti és rétegtudat kötöttsége, illetve értékei (Escarpit, 1973)

A multikultúra sokszínüsége, pozitív kicsengésủ megvilágítása más irányú vitát is megnyitott: mit tesz a globalizáció és az európai egységesülés a nemzeti kultúrákkal, erősíti vagy gyengíti azokat? Van-e globalizációs civilizáció és abban megőrizhető-e a különbözőség? (Gombár, Lengyel 2000)

\section{„Magyar vagyok, de európai..."}

József Attilával együtt ugyanezt gondolom, érzem. Nem gond világpolgárnak és hazafinak egyszerre lenem. Ez nem jelenti azt, hogy ne érteném azok dilemmáját, akik ezt másképp látják és érzik. Szocioló- 
giatörténetet tanítva ébredtem rá, hogy már a 18. században született javaslat az Európai Köztársaságról. (Henri de Saint Simon, 1963)

De Európa történetét nézve is az látjuk: közlekedések és távolodások váltakoztak az évszázadok során. Az utóbbi években megjelent Európakönyvek eleven és izgató, aggódó és reményteli sorokat egyáltalán leírnak. Komoly tábora van annak, hogy ha pl. az Európai Unió nem jön létre, a létét megkérdőjelező generációk meg sem születtek volna. Igen, a vágyott béke bekövetkezett és ez nagy érték. Az aktuális kérdések és a felgyorsult változások - melyek mögött az attitüdváltás nyilván elmaradt, a veszélyérzet pedig megnőtt - kiváltották a szakemberek aktivitását és kíváncsiságát. Ontják a szakemberek a könyveket. Hogyan alakítja át életünket a globalizáció? (Anthony Giddens, 2000) Mennyi globalizációt bír el az ember? (Rüdiger Safranski, 2004) Van, aki Európa történelméről mesél. (Jacques le Goff, 2003) Mások a sokszínü Európát mutatják be. (Emma Hartly, 2006)

Hasonló és ellentmondásaival együtt is figyelemreméltó a rendszerváltást követő hazai szakmai érdeklődés mind a nemzeti, mind a nemzetközi fordulatok ideológiák és történések iránt. Személyesen két elemzés késztetett gondolkodásra, a szakma két elismert tudósa tollából. Ilyen a Nemzet által homályosan (Csepeli György, 1992), és az okos, szellemes Proletár reneszánsz. (Hankiss Elemér, 1999)

Segítenek megérteni a nemzetté válás történeti útját és felvillantják a nemzetközi jelenségeket, a szerveződésekhez való csatlakozások ellentmondásos fogadását, hazai jelenségeit. Csepeli vizsgálatában ugyan a megkérdezettek 56\%-a jelentősnek tartotta a nemzethez tartozást, de nem volt bennük bezárkózás vagy nemzetféltés. 55\% mindkét irányt realitásnak vélte, $36 \%$ „nemezetköziesedést” jósol a rendszerváltás éveiben (Csepeli György, 1992, 155)

Nagyon jellemzőnek találom a változások és azok értelmezése, értékelése során a szakmai szókincs változásait. 10 éve még a modernizáció keretében mertem értelmezni a világ jelenségeit. Centrum-periféria, szerves-szervetlen fejlődés, adaptáció-másolás, civilizáció-kultúra fogalmakkal ragadtuk meg azt a folyamatot, amelyet korszerüsödésnek, változásnak, haladásnak véltünk. Ugyanazt ragadtuk meg ezekkel: felvenni a kor ritmusát, bekapcsolódni a világfolyamatokba, követni az érdemes külföldi mintákat. Mindezek társadalmi feltétele a szaktudás, müködőképes intézmények, attitüdváltás és az emberi kapcsolatok minőségének változása. 
A modernizáció már feledésbe merült, a posztmodernt még meg sem fejtettük és a globalizációhoz érkeztünk. Domináns az a vélemény, hogy nincs más alternatíva. Világméretü veszélyekkel kell szembenézni, melyek egy részével a természet fenyeget (lehülés, felmelegedés, éhezés, katasztrófák), más részüket magunk okozzuk (túlterhelés, túlfogyasztás, rossz szokások, deviancia, előítélet).

Együtt érdemes velük szembenézni. Azt is állítom ezzel, hogy a globalizáció nem pusztán nemzetek közötti/feletti gazdasági intézmény, hanem ökológiai probléma megelőző törekvés és kulturális, politikai kérdésekben is túlmutat a nemzeten, államokon. Ilyen kifejezések kísérik útját, mint multikultúra, globális szolidaritás, világtársadalom. Mellette hangsúlyt kap a nemzeti sajátosságok megtartása és a különbözőség megőrzésre méltó értékként kezelése. (Gombár, 2000)

$\mathrm{Az}$ is közkinccsé vált megállapítás, hogy az állam vagy nemzet túl kicsi a nagy problémák megoldásához és túl nagy a régió, település és a kis közösség ügyeinek elrendezéséhez. Ennek belátása, felismerése is sokféle megoldás esélyeit veti fel. Vannak, akik dramatizálják és vannak, akik idealizálják a „világtársadalom” esélyét. Kétségtelen, hogy egy új paradigma rizikót is, kihívást is jelent. Térségünkben bonyolítja a helyzetet, hogy nem csak a külső, hanem a belső helyzet is lényegében változott meg.

Ezért gondoltunk arra, hogy ha változatosan is, de szólnunk kell a hazai rendszerváltásról. Ingoványos területre lép ezzel a szociológus amiatt, hogy nem szakértő. De nem is kell ilyen mélységekig elmenni.

Az elsö kérdés, miért is bomlott fel az államszocialista rendszer?

A szovjetunió felbomlása, az ezzel járó nemzetközi orientáció váltás, a korábban említett globalizáció önmagában is komoly változások indikátora. Ennél persze sokkal nehezebb belső események történtek. Mint oly sokszor, társadalmi feszültségek és bajok elöre nem jelzik, mikor robbannak. A hatékonytalan gazdaság, a stabilan meglevő szegénység, a deviáns jelenségek, az erőltetetett közösségek korlátai, a nemzeti identitás és függetlenség iránti igény, az életnívó romlása, a vágy egy demokratikusan berendezett politikai rendszerre több más okkal együtt váratlanul és gyorsan átlépte a radikális reform elképzelést és rendszerváltást hozott. A Beke Kata könyv cím a „Jézus Mária győztünk” adja vissza a meglepő és a felelősséget tekintve nyomasztó, ám a tömegekben reményt keltő hangulatot 
Azt remélte a társadalom, hogy gyors és látványos változások történnek. Ma már tudjuk, hogy ez nehezebb szülés. A hazai tőkehiány a politikai kultúra hiánya, koncepció zavar, a tömegesé és tartóssá váló munkanélküliség, a hajléktalanság, a gyanakvás és a hárítások, a bizalmatlanság ellentmondásos eredményt hoztak. Mára súlyosabb problémát látok, de erről kitünő és hozzáértő emberek érdemi elemzéseket adnak a sok szempontból kettészakadt hazáról, a megosztott szekértáboros értelmiséggel. Minden estre a szeretet hiány csökkentette a szolidaritást, a biztonság hiánya apasztotta a bizalmat, az egészség hiánya illetve a beteg társadalom elvett az életerőből és a reményekből. A közügyektől eltávolodtak sokan lent és ami súlyosabb fent is. Feszült fáradt a társadalom a terhek a gyengéket sújtják - sokak szerint magára maradt a társadalom.

\section{A második kérdés, mennyiben történt meg a rendszerváltás?}

Csak a tendenciákat jelöljük meg. A gazdaságban elindult és bukdácsolva létrejött a polgárosodás elemi mozgatója, a magántulajdonon alapuló piacgazdaság a nemzetközi tőke bevonásával. A politikai rendszer lényegében átalakult: több pártrendszeren nyugvó, szabad választásokkal demokratikusnak mondható intézményrendszer indult útjára. A változó társadalom szerkezetében megjelent a polgárság (náluk vállalkozóknak jelöli öket a köznyelv). Gyakran megtörténik, hogy ez tőke és szellemi tőke híján kényszervállalkozás lett. Ezzel együtt egy új, bérmunkás réteg is alakult. Ha egyáltalán jó kifejezés a „szociális rendszerváltás”, értjük ezt úgy, hogy mindenki szerény nívón, emberhez méltó módon élhesse mindennapjait, ez koránt sem következett be. Beszélhetnénk a kultúráról is, de ez nagyobb ívü elemzést kíván. Sok a rosszízü tapasztalás, félő, hogy a politika eszközévé válik, de legalábbis nem értik egymás nyelvét.

A kultúra, hagyomány... kurzus utolsó rövid része azért került be programba és beszélgetésünkbe, mert a kultúra viselkedési kultúra is. A társaságképes viselkedés - az illemtan - megkönnyíti a kapcsolatteremtést, szabályozza a viselkedést. Ezzel is beilleszkedünk a társadalomba. Persze nem mindenki teszi ezt, mert vagy nem tudja, vagy nem akarja ezeket a szokásokat, szabályokat betartani.

Bravúrosan és szellemesen mutatja be Elias illemtani könyvek elemzésével - a középkortól a 20. század harmadáig, hogyan nő meg az ember szégyenérzetének a küszöbe azzal az igénnyel, hogy másoknak 
megfeleljen. Mindezt több száz év illemtani könyveinek elemzésével illusztrálja: asztali szokások, az evés, a kés és a villa használata, az orrtörlés, a köpködés, a hálószobában való viselkedés, a természetes szükségletek nyilvánossága okán. Megtudjuk, hogyan kell ülni, valakit üdvözölni, társalogni. (Elias, 1987) Ebben az értelemben szerinte a civilizáció az emberi viselkedés sajátos megváltozása. Minden esetben felismerhető ezekben az adott társadalom hierarchiája is.

Hallatlanul érdekes és érdeklődésre számot tartó ilyen szempontból felvillantani Hall: Rejtett dimenziók müvét, amelyböl kiderül, hogy milyenek a németek, a franciák, az angolok, a japánok és az arabok? Világossá válik a népek kulturális mintáinak és örökölt hagyományainak különbsége és gondolkodásuk mássága is. A szerző képes társadalmi hátteret láttatni a térbeli dimenzióval is, centiméter pontossággal illusztrálva a távolságot az emberek között. Bemutatja a bizalmas, a személyes, a társasági és a nyilvános távolság finomságait és jelentőségét. (Hall, 1996)

Miközben mi emberek sokkal jobban hasonlítunk, mint különbözünk, izgalmas a szellemes és jellemző különbségeket látni népek, nemzetek között a viselkedési kultúrában.

A viselkedés mai problémái, a durva beszéd, az agresszivitás, a tisztelet és az intimitás hiánya, a türelmetlenség, lekezelés indokolják, hogy szó essék erről.

Része a jelenségnek a kommunikáció és az ezt befolyásoló tömegkommunikáció. A kapcsolatteremtés nélkül nincs társadalmi együttélés. Ezért gondoltam, hogy tekintsük át és ismerjük meg a verbális és nem verbális kommunikációt, részben gyakoroljuk is. A Szó-beszéd (Alan Pease-Alan Garner, 1989) és a Testbeszéd (Alan Pease, 1981) humoros és szellemes példái, illusztrációi nekünk is megszerezték a napi vidámságot és örömöt.

Bővebben két elemet emeltünk ki: az ünnepeket és az ajándékozást. Az elsőt azért, mert a gondokkal teli hétköznapokat nehéz lenne elviselni üdítő ünnepek nélkül. A feltöltődés, regenerálódás, szóval az értékesen eltöltött szabadidő és szórakozás, pihenés tudatosítása fontos érték. Végülis nem csak munkával él az ember. Az emberiséget nem ejtették a fejére. Ünnepeket talált ki magának. Már az ókori Rómában 180 ünnepnapot tartottak számon. A ,sötét” középkorban is 100-nál több volt az ilyen nap. Szerzők szerint a hétköznap ünnepek nélkül olyan lenne, mint a hosszú országút fogadók nélkül. (Erdei-Zolnai, 1969) 
Ezt nevezi a kérdés szakembere ünnepnapi tudásnak: tudni örömet szerezni és örömet fogadni. (Ferge Zsuzsa, 1984) Vannak aggódó hangok, hogy mára kiüresedtek az ünnepek, dominál a külsőség és a látvány, kevés az átélés, igazi vidámság nincs.

Az ünnep része a szeretet, figyelmességet üzenő gesztus az ajándékozás is. A történelem során több ajándékozási típus jelent meg. Ilyenek: a kötelező, a hivatalos, az illendő és végül a szívből jövő ajándék. Az utóbbit tekintsük igazi örömforrásnak.

\section{„Simogatni az ifjúság fejét..”}

A következőkben az Önkéntes munka és lehetőségei...okán az ifjúság szempontjából gondolkodtunk el azon, hogy megkerülhetetlen a gyerek társadalomnak és az ifjúságnak illetve a politikai rendszer értelmezésének beemelése írásunkba. Az előzményekből következik: ifjúsággal foglalkozó közegben feltételezhető az a felelősség és törekvés, amellyel segítjük felnőtté válásukat a gyermekvédelemtől a helyzetbe hozásukig.

Ha értelmiség jelöltekröl beszélünk - ráadásul a határ két oldalán élőkről - akkor személyiségük alakítása és a hivatásra való felkészítés a kötelességünk. Jó volna tudni, hogy ezzel segítjük jövőjüket, a hatalom birtokosai pedig biztosítják ezt a jövőt. Hiszen végül is a következő évtizedek szellemi elitjéről van szó. Személyesen önismeretük, identitásuk azon is múlik, hogy mi segítjük-e ebbe n őket. Nekünk sem mindegy, mit hagyunk rájuk. Vajon ,áldó imádság mellett mondják el szent neveinket” (Petőfi), vagy azért kell imádkoznunk, hogy: ,az utódok ahogy nőnek, ne átkozzák a temetőket” (Tvardovszkij).

A történelem nem kényeztette el sem a gyermekeket, sem az ifjúságot. A kisgyermek korból századokon át egyenesen a munkás felnőtt korba léptek. A szakma szerint voltak családba zárva, termelésbe kényszerítve és voltak fogyasztásba hajszolva. Tudjuk a magyar vizsgálatokból, hogy egyharmaduk esélytelen, mert nem piacképes. (GazsóLaki, 2004) Gondoljuk, ideje érdekeltté tenni őket dolgaik elrendezésében, segíteni önismeretüket, politikai döntéseket sürgetni érdekükben. Fontos tehát ismerni, hogyan érzik magukat, látnak-e elérhető célokat, van-e jövőképük, miért vannak távol a közügyektöl, miért érdektelenek a politika iránt (a polis értelmében)? Ezekről szólnak az utóbbi kutatások is. (Ifjúság 2000, 2004, 2008) 
Rövid összegzésekben az alábbi kérdésekről szólunk:

- a demográfiai szerkezeten belül a gyermekkorról és az ifjúságról,

- az ifjúságszociológiáról, a nemzetközi és hazai ifjúságkutatásokról,

- a szocializációról, ahol társadalmi lénnyé válunk,

- amit átadunk a szocializációban: értékek, normák, szerepek,

- a politikai rendszerröl,

- végül a civilségröl, önkéntes munkáról.

A szociális szakmában járatos a kiégés problémájával naponta szembekerülő, hivatásuk magaslatán álló kollégáink talán hitelesebb tapasztalati képet tudnának nálamnál adni a mai magyar családok azon részéről, ahol és ahonnan érkeznek a nem kívánatos gyerekek. Jobban belelátnak a formálisan „ép” családok gondjaiba is. Jó volna inspirálni ezeket a gyakorló szakembereket, hogy ragadjanak tollat időnként. A felderítő vizsgálatok körét gyarapíthatnánk. Netán épüljenek be az egyetemek oktató gárdájába és vegyenek részt az értelmiség képzésében. Valamint sokkal szervesebb összehangolásra volna szükség - a jó példák miatt.

\section{Gyermekkor}

A demográfiai szerkezet - föként a kor és nem szerinti megoszlás azért is érdekes, mert biológiai-fiziológiai különbségnek lettek társadalmi következményei. Ezekről nem kívánok szólni, de arról a tényről igen, hogy az emberiség történetében változó gyermekfelfogások éltek, de ezzel lényegében a 60-as években kezdtek foglalkozni a kutatók: Aries, Pollock, Piage, Erikson és sokan mások. A középkorban pl. a társadalom fele gyermek volt, mégsem ragadta magával a róluk való kutatói érdeklődést. Most is vitatott kérdés, volt-e egyáltalán gyermekkor és ha igen, jó volt-e gyereknek lenni? A domináns állásfoglalás a felé mutat, hogy a válasz nem - mindkét kérdésre. Az volt az elv, hogy a gyermekkort nem élvezni, hanem elviselni és túlélni kell. Hosszú csecsemőkor után a munka világában találták magukat.

A „Gyermekkor története” szöveggyüjtemény igazán nívós és izgalmas tanulmányai arról győznek meg, hogy nem lehet mai szemmel nézni az akkori szülö-gyermek kapcsolatra. A gyermek inkább teher volt és veszélyeztette a többiek életesélyeit. Így is sokan meghaltak. A 17. és 18. 
században 1000 csecsemőből 169 születéskor meghalt. Olyan állítás is van, hogy a gyermekek 33, de akár 90\%-a meghalt egy éves kora előtt. (Pukánszky-Vajda, 1998, 321) Ezzel együtt a születés a női élet központi eseménye volt. De a gyermekek szükségleteinek felismerése, megértésük, együttérzésük csak mára történik meg. Mint írják, nem a szülői szeretet, hanem az emocionális érettség hiányzott egy olyan korban, maikor a felnőtteket is sok brutalitás érte. A trend végül is a közeledés a felnőttgyermek között. A végeredmény, hogy a gyermek örömforrás lett. (Pukánszky-Vajda, 1998) Ehhez a nőkérdésnek, a nemek viszonyának, a szülöi szerepeknek és a tudománynak is be kellett érnie. A hazai kutatások is megsokasodtak az említett szerzőkön túl is.

Nagy utat járt be a gyermekkép és a megítélés a történelem során, míg eljutott a rituális gyermekgyilkosságoktól a gyermekjogok nemzetközi deklarálásáig. A Gyermekek jogairól szóló New York-i egyezmény közhelyesen szólva a deklarációk birodalmában mérföldkő.

\section{Ifjúság és ifjúságkutatás}

Paraszt nagyapámtól tudom, hogy fiatalnak lenni nem érdem, hanem állapot. Csak azt nem tudtam és Ö sem, hogy egy szociológus veszett el benne. Statisztikailag persze könnyen definiálható, kit tekintünk fiatalnak. Általában azt az azonos évjáratot, makrocsoportot, amely 14/18 és 30 év között van. A korszakolás eltérő és a népesedési arányok nagyon fontosak és jellemzőek egy társadalom életében a születésekkel és halálozással együtt. Az értelmezések is sokszínüek, több tudomány is felségterületének tekinti az ifjúságot. Csak a felsorolás igényével tekintjük át:

- egységesnek látszó makrotársadalmi csoport,

- azonos évjáratok összessége,

- önálló társadalmi réteg,

- a társadalom tagolása szerint belül differenciált csoport (nem, kor, státus stb.),

- átmenet a gyermekkorból a felnőtt korba,

- közös élményanyagot hordozó együttes,

- a társadalmi megújulást szimbolizáló réteg,

- új fogyasztói osztály,

- biológiai, fiziológiai, pszichológiai és társadalmi állapot. (Mojzesné, 2002, 8) 
Gyakran úgy vetődik fel az ifjúsággal való foglalkozás, hogy baj van velük. Nem osztom ezt a nézetet, mert a „baj” a hivatalos társadalommal van ilyenkor, amely nem veszi idejében észre, hogy a fiatalok nem érzik jól magukat a bőrükben. Elias egyenesen úgy látta 1938-ban a helyzetüket - persze két eröteljes európai diktatúra idején - hogy a történelem során: „A maihoz képest csekély volt a távolság a felnőtt és gyerek között. Ma elöírások és szabályok oly szoros gyürüje fonódik az ember köré, a társadalmi életnek az emberi szokásokat alakító cenzúrája és nyomása oly erős, hogy a felnövekvő gyereknek egyetlen alternatívája van: vagy aláveti magát a viselkedés társadalmilag megkövetelt alakításának vagy kizárják a civilizált társadalmi életböl” (Elias, 1987, 283)

Nyilván vannak kitérők a születő generációk szocializációjában, helyzetük megítélésében, erre utal a szerző. De mégis a közeledés dominál a 20. század első felében. Minden esetre a nyitottabbá váló világ, az alternatívák növekedése, a felgyorsult életritmus és az ifjúkor meghosszabbodása együtt mintakövetőkből mintaadókká minősítette a fiatalokat. A származás helyett a teljesítmény került és csökkent a társadalmi csoportok távolsága. Más lett a felnőttekkel való kapcsolat. Átalakult a családi élet szerepe és szabadsága. Nőtt a személyiség autonómiája. Megváltozott amitől féltek és amiben hittek az emberek. A tanulság lett a betöltött pozíció és a munkahely feltétele. Kiterjedt az intézményes szocializáció. Véleményformáló csoport lett az ifjúság. Több kutató Európában már a 60-as évektől ifjúsági korszakváltásról beszél. Ehhez hosszú út vezetett. Hol és milyen problémák hívták fel a figyelmet rájuk, aminek alapján viharos gyorsasággal élénkült meg a politikai és tudományos érdeklődés irántuk? Német kutatók azt a következtetést vonták le, hogy új ifjúság szerveződött, mely már nem egyszerüen „ellátási” problémát jelent, hanem önálló nemzedéki csoportot. (Gábor, 1992)

Láthatóan olyan társadalmi háttér alakult ki a modernizáció világában, mely azonos jelenségekben nyilvánult meg, de sajátos reakciókat váltott ki döntéshozókban. Mindenütt megszületett az ifjúságszociológia.

Az 50-es évek Amerikájában az elavult egyetemi képzési struktúra, a bevándorlók gyermekeinek terjedő devianciája, a fiatalok erős békevágya, elégedetlenség a gigantikus vállalatokkal, az intimebb élet iránti igény váltotta ki a látványos elégedetlenséget, amire választ kell adni.

A 60-as évek Európájában késve jelentkeztek a kezelésre váró problémák. A megelőző - háborút követő évtized - ugyan egy lelkileg sérült ifjúsággal találta szemben magát. Ök voltak az apátlan generáció, 
de nem voltak egzisztenciális gondjaik. Ám a jelzett években a kapitalizmusról is kiderült, hogy nem fenékig tejföl. A recesszió, a gazdasági lejt menet a diákokban komoly elégedetlenséget szított. Ennek politikai felhangjai erősödtek. Senkinek nem hittek, aki elmúlt 35 éves - szlogen mutatta, hogy a diákmozgalom nem csak a hatalommal volt elégedetlen, hanem a szüleivel is. A német és francia diákok és fiatal értelmiségiek megdöngették a polgári társadalom kapuit.

A magyar ifjúságkutatások a 70-es években kezdődtek és folyamatosan jelen vannak, ha részleteit nincs is módunk felvázolni. Szakmánk nagy nevei jelzik fontosságát és a hatalom érdeklődését is. A romló életszínvonal, a felbomló családok, az átlagba zárt egyéniségek, az egyetemre jutás korlátai, bár kiterjedt az alapiskolai tanulás, de igen nagy lemorzsolódással járt. Összességében a túlpolitizált társadalom ellenére a fiatalok életében idegen maradt a politika.

Részletesebben vázoltuk a magyar ifjúságkutatásokat, melyeknek íve azt mutatja, hogy a feltételezés, miszerint a szocializmusban született generáció rendszer iránti hüsége, elkötelezettsége tételezhetö, nem bizonyult realitásnak a 80-as években. Különösen a személyes szabadságot és autonómiát hiányolták. A rendszerváltás utáni évek nagy kutatói kérdése az volt, hogy nyertese vagy vesztese-e az ifjúság a változásoknak és a domináns válasz (hosszabb távon is láthatóan) az utóbbi. A romló helyzet és körülmények minden tényezője szerint is az. Munkanélküliség, jövedelem, lakás, tanulás, élet és munka kezdés esélyei nem vigasztalóak. Ingadozó a jövőre vonatkozó remény is.

A 2000-es évek három nagy ifjúságkutatása azt mutatja, hogy mind a kutatók, mind a hatalom fontos kérdésnek tartja az ifjúságot és jövőjét, de lassan és alig transzformálja át problémái megoldását politikai döntésekké. Máig vannak jelei annak, hogy még mindig nem dőlt el - a társadalom aktív résztvevőinek vagy a szociális válság hordozóinak tekinti-e az ifjúságot. Egyébként imponáló „látleletek”, reprezentatív kutatások születtek, melyek keskeny rést sem hagytak az elmúlt évtizedek ifjúsági vizsgálataiban. Ez jó. Csak a legfontosabbakat említem:

Ifjúságszociológia (Sükösd-Huszár, 1969)

A magyar ifjúság a nyolcvanas években (Békés, 1984)

Rendszerváltozás és ifjúság (Gazsó-Stumpf, 1992)

Civilizációs korszakváltás és ifjúság (Gábor, 1992)

Fiatalok az új kapitalizmusban (Gazsó-Laki, 2004)

Ifjúság 2000., 2004., 2008. (Szabó-Bauer-Laki) 
Érdemes volna sok adattal bemutatni e kutatások eredményeit, netán a 3 nagy kutatás konzekvenciáit egybevetni. Ez egy másik tanulmány feladata lesz. Szempontunkból fontos annak felvillantása, hogy 2008ban milyen volt a társadalmi közérzete a 15-29 éves korosztálynak. Az előző két kutatáshoz képest romlottak a megítélések. A gazdaság helyzete a megelőző 10 évben a válasz: 84\%-uk szerint romlott, 13\%- szerint változatlan, $3 \%$ lát javulást. $80 \%$ az életszínvonal romlását látja. Ettől jobb a személyes élet megítélése. Igen alacsony viszont a politika iránti érdeklődés. A fiatalok $60 \%$-át egyáltalán nem érdekli. Döntő többségük úgy ítéli meg, hogy a politikusokat sem érdekli az ifjúság véleménye. Az előző két kutatásban is ez volt a helyzet. (Szabó-Bauer, 2009. 107) Kívánatos lenne, ha megjelenne a kutatásokban az a nyugaton aktuális szempont, mely nem problémaként, hanem erőforrásként tekint rájuk.

Magam is megfaggattam a kurzus hallgatóit. 3 olyan társadalmi probléma megjelölését kértem, mely érinti az ifjúságot (a határ mindkét oldalán), illetve a megoldási javaslatokról is beszéltünk. A gyakorlatiság alapján 1. és 2 . helyre a munkanélküliség és a deviancia került fordított sorrendben a két színtéren. Az utóbbi az országos vizsgálatban is a legégetőbb társadalmi-ifjúsági problémaként jelent meg. 3. helyen itthon a szegénység az iskolázatlansággal együtt, odaát az agresszió az elöítélettel együtt kapott többséget. Az általánosítás szándéka nélkül jegyzem meg, benne élnek ezek a fiatalok a társadalomban.

\section{A szocializáció}

Hol is történik velünk ez a benne élés? Azt a folyamatot, amelyben a társadalom tagjaivá válnak a megszülető generációk, szocializációnak = társadalmasodásnak nevezzük. Kézikönyveink nálamnál jobban leírják lényegét. Ezért röviden foglaljuk össze a szocializáció szerintünk fontos mozzanatait. Itt válunk biológiai lényből társadalmi lénnyé. Bevezetés történik a társadalomba, kialakul az ember személyisége, azonosságtudata, a kultúra átvétele. Kiemelkedőnek tekintem Riesman Magányos tömeg-ét, mely történeti áttekintést ad arról, hogyan alakulnak ennek típusai és színterei koronként. A hagyományos társadalmakban az ember (és társadalom) hagyomány által irányított és a család szocializálja. A klasszikus kapitalizmusban belülről irányított az egyén és az iskola lép be színtérként. A 20. században kívülről irányított az ember 
és a tömegkommunikáció jut jelentőséghez színtérként. Itt válik fontossá a többieknek való megfelelés igénye. (Riesman, 1973)

Fontos kapaszkodónak találom Kozma Tamás: Tudásgyárá-nak megállapítását, hogy a szocializáció csak részben beilleszkedés, részben perszonalizáció is. (Kozma, 1985) Végül a hazai szakma e témában egyedülálló elméleti munkáját említem, Somlai Péter: Szocializációjá-t, melyben a kultúra átörökítési folyamataként jelöli a szocializációt és a színterekről sem a hagyományos módon ír. (Somlai, 1997) Magam elfogadom a klasszikus felosztást a spontán és intézményes /család, iskola, egyéb szervezetek/ színteréről, de - Riesmantól is tanulva - beemelem a tömegkommunikációt és azt a gondolatomat, hogy a kulturális intézményrendszer egésze is tudatosan szocializál. Végül a szocializáció egész életünkön át tart, és a célja a szociális integráció. Létezik kiilleszkedés és reszocializáció is.

\section{4. Érték, norma szerep}

Ezek után - annak tudatában, hogy felnőtté válni nehéz - válaszra vár, mit is tanulunk a szocializációban? Íme a válasz:

értékeket

normákat és

szerepeket.

Az első tényezőt nézve, az érték a többség által hitelesített kulturális alapelv. Egyszerübben szólva minden olyan törekvés, dolog, amiért érdemes hajtani, élni. Merton szerint ilyen Amerikában az anyagi siker (Merton, 1980), a keleti kultúrában a család. De a tanulás, müvészet szeretet, barátság stb. is ilyen értékek.

A norma viselkedési, magatartási szabály, melyet adott társadalom (csoport) jelöl ki és csoportnyomás hatására betartunk. Ez lehet írott szabály, vagyis jogi norma. Lehet erkölcsi szabály, melyet egy közösség hitelesít és megszegése esetén büntet. A vallási szabály a hiten alapszik. A magatartási (illem) szabályt szokás vagy leírás is szabályozhatja. Végül a divatszabály, mely ez esetben a megjelenést írja elő vagy várja el. Mindig, ha egy új érték megjelenik, létrejön az azt védő norma (pl. a magántulajdon).

A szerep a státusunkhoz, pozíciónkhoz tartozó elvárások összessége (pl. az orvosé a gyógyítás). Általános szerep a nemünk, állandó szerep a szülői, a gyermeké, véletlen vagy alkalmi szerep pl. ha vásárlóvá válunk, vagy tanúskodunk. Amiért fontos erről szólni, mert egyszerre több szerepet hordozunk és ebből szerepzavar, sőt szerepkonfliktus 
következhet. Ezek felismerése és feloldása része a mindennapi életünknek. A csoportnyomásra normákat betartó és szerepet megvalósító embert nevezi Aronson konformnak.

\section{Politika, politikai rendszer, civilség}

A poliszért végzett tevékenység értelmében használom a kifejezést. Nevezhetném közügynek is a politikát, cselekvési formának, érdekérvényesítési módnak, a vezetők hatásának a társadalom egészére. Ma a gyakorlatban arra irányuló tevékenység, hogy bizonyos csoportok döntési pozícióba jussanak és uralmat gyakoroljanak. A weberi értelemben vett uralomról, az államról, a hatalomgyakorlás módjáról, a politikai kultúráról, a demokráciáról és a diktatúráról csak említést teszünk annak érdekében, hogy eljussunk az állam és a piac dominanciáját befolyásoló, de tőle független civil, öntevékeny szervezetekig és az ifjúságpolitikáig.

A civilség nem állami, sőt független attól, de állampolgári jog arra, hogy önként részt vehess a közügyekben, ellenszolgáltatás nélkül szolgáld a közjót. Ezt a magyar politikai múlt ismerte, de elfelejtettük. Nem csak lehetséges, de szükséges felelevenítése a saját és mindazok érdekében, akik szükséget szenvednek és azt a piacról nem tudják kielégíteni. Szóval elosztási korrekció, társadalmi ellenőrzés, érdekérvényesítés, szolidaritás erősítése a feladata. Ma Magyarországon az egyesületek és alapítványok száma 50000. Tehát ennyi civil szerveződés van, és ennek 15\%-a ifjúsági jellegü, föként vallási, sport, szabadidő, kultúra profillal (Nagy Ádám, 2007, 123). Jó ügyek mellé állni, non-profitnak lenni, civil kurázsit vállalni és a közjót szolgálni a demokratikus társadalmak fejlesztendő attitüdje. Ezért olyan fontos az ifjúság körében ezt felvetni, megbeszélni, gyakorolni.

A társadalom alulról is meglódulhat ebben a lelassult és „értékrendetlen” világunkban. Rá kell döbbennünk az erkölcsét, tisztességét megőrző embereket, hogy magánügyeik a legszorosabban vett közügyek. Hiszen attól már nem csak ők kerültek távol, hanem a hatalmat gyakorló döntéshozók egy része is.

De ehhez sokat kell tenni. Európában ifjúsági munkának nevezik ezt a folyamatot. Nálunk vitatkoznak róla, és felvetődött, hogy ifjúságpolitika kell hozzá. Van, aki igenli, van aki ellenzi. Közbülső állásfoglalás, hogy iskolai tantárgy legyen, netán érdekérvényesítés vagy esetleg választói magatartásra nevelés. De az is lehet, hogy folyamatos párbeszédet kellene folytatni a politikának az ifjúsággal - minderröl - egyen- 
rangúságának elismerésével. (Kátai, 2006). Nem elég megtanulnia az életben maradás képességét, az önmagáról való gondoskodás formáit, elkerülését a veszélyeknek. Mint a szakemberek mondják, az érett felnőttség nem kapcsolható pontosan életkorhoz.

Nem könnyű elindulni, mert a mai ifjúság másképp tekint magára és a világra, mint a felnőttek. Közéleti részvétele lesújtó, miközben fejlesztése fontos. Maga sem hisz abban, hogy szükség van rá, a szakemberek szerint nem látják értelmét.

A tanulmány gondolatébresztő, ennek megfelelően vázlatos. De talán segít abban, hogy akik társadalmi kérdésekben elkötelezettek vagyunk és ifjúságot bíztak ránk, próbálkozzunk hivatásunkban együttműködni érdekükben, netán értük és természetesen velük.

\section{Irodalom}

A kérdéses civilizáció (2000): szerk. Gombár Csaba-Volosin Hédi, Helikon-Korridor A magyar ifjúság a nyolcvanas években (1984) szerk. Békés Pál, Kossuth Könyvkiadó BAYER József (1999): A politikatudomány alapjai. Napvilág Kiadó

BRAUDEL, Ferdinand (2008): A kapitalizmus dinamikája. Európa Könyvkiadó

CSEPELI György (1992): Nemzet által homályosan. Századvég Kiadó

ELIAS, Norbert (1987): A civilizáció folyamata. Gondolat

FERGE Zsuzsa (1984): Az iskolarendszer és az iskolai tudás társadalmi meghatározottsága. Akadémiai Kiadó

GAZsó Ferenc - LAKI László (1998): Esélyek és orientációk. Fiatalok az ezredfordulón. Napvilág Kiadó

GAZSÓ Ferenc - LAKI László (2000): Fiatalok az újkapitalizmusban. Napvilág Kiadó

GIDDENS, Anthony (2000): Elszabadult világ. Napvilág Kiadó

HALL, Edward (1966): Rejtett dimenziók. Gondolat Kiadó

HANKISS Elemér (1999): Proletár reneszánsz. Helikon Kiadó

HARTLEy, Emma (2007): Sokszínü Európa. HVG Könyvek, HVG Kiadó, Zrt.

Ifjúság 2000 (2002): szerk. Bauer Béla - Szabó Andrea - Laki László, Nemzeti Ifjúságkutató Intézet

Ifjúság 2004 (2005): szerk. Bauer Béla - Szabó Andrea, Mobilitas

Ifjúság 2008 (2009): szerk. Szabó Andrea - Bauer Béla, Ifjúság 2008. /2009/, Szociálpolitikai és Munkaügyi Intézet 
Ifjúságsegités (2007): szerk. Nagy Ádám, Belvedere-Palócvilág, U-V-G

Ifjúságszociológia (1969): szerk. Huszár Tibor - Sükösd Mihály Közgazdasági és Jogi Kiadó

J. NAGY László (2002): Az európai integráció politikai története. Maxim Kiadó, Szeged

KÁTAI Gábor (2006): Gondolatok az ifjúságpolitikáról. Belvedere

KozMA Tamás (1985): Tudásgyár? Az iskola, mint társadalmi szervezet. Közgazdasági és Jogi Kiadó

LE GofF, Jacques (2003): ... Európa történetéröl mesél. AB OVO

LosoncZi Ágnes (2009): Az ember ideje. Holnap Kiadó

MERTON, K. Robert (1980): Társadalomelmélet és társadalmi struktúra. Gondolat Kiadó

Nem csak munkával él az ember (1986): szerk. Jeremy Cherfas-Roger Lewin, Gondolat

ÖRKÉNY Antal - SZABÓ Ildikó (1998): Tizenévesek állampolgári kultúrája. Minoritas Alapítvány

PeAse, Alan (1989): Testbeszéd. Park Kiadó

PeASE, Alan- Gerner, Alan (1989): Szó-beszéd. Park Kiadó

POZSGAY Imre - POLGÁR Tibor (2003): A rendszerváltás /k/ára. Kossuth Könyvkiadó

PUKÁNSZKY Béla - VAJDA Zsuzsanna (1998): A gyermekkor története. Eötvös József Könyvkiadó

Rendszerváltozás és ifjúság (1992): Szerk. Gazsó-Stumpf MTA Politikatudományi Intézete

SAFRANSKI, Rüdiger (2004): Mennyi globalizációt bir el az ember? Európa Könyvkiadó

SOMLAI Péter (1997): Szocializáció. Corvina Kiadó

UTRIO, Kaari (1989): Éva lányai. Corvina Kiadó 


\title{
A SZOCIÁLPEDAGÓGUS HALLGATÓK KOMMUNIKÁCIÓJÁNAK FEJLESZTÉSÉHEZ
}

\author{
ABOUT IMPROVING SOCIAL PEDAGOGY STUDENTS' \\ COMMUNICATION SKILLS
}

\begin{abstract}
Communication can be described as a basic skill in the social professions This paper presents the ways which an educational youth worker needs to communicate both orally and in writing as part of his or her daily work. Thepaper also discusses certain special features in the language use of such workers e.g. special vocabulary or phrases. Besides, the paper gives several ideas on how to improve a social pedagogy student's communication skills. These exercises aim to improve general communication skills, communication with clients and their family members and, last but not least, with the surroundings of a social institution.
\end{abstract}

\section{Bevezetés}

Az emberi kommunikáció szabályszerüségeinek megteremtésében szerepet játszó tényezők között meghatározó helye van a közlés címzettjének, a kommunikációs partnernek. A kommunikáció folyamata csak a közlést vevő személy vagy személyek révén teljesedhet be. A kommunikátor a partner figyelmének fenntartására törekszik, közléseinek megalkotását befolyásolja az is, milyen képet alkot önmagában a közlésfolyamatban részt vevő felekről. A szociálpedagógus nincs könnyü helyzetben. Nap mint nap nehéz sorsú emberekkel, gyerekekkel, felnőttekkel, idősekkel egyaránt szót kell értenie. Munkájának ugyanakkor elen-

\footnotetext{
${ }^{8}$ Dr. Nemes Magdolna adjunktus, Debreceni Egyetem Gyermeknevelési és Felnőttképzési Kar
} 
gedhetetlen része a hivatalos iratok készítése, a kapcsolattartás különböző intézményekkel és a pályázatok írása is.

Napjainkban óriási az igény a kommunikáció hatékonyságát növelő gyakorlati ismeretekre. A továbbiakban a nyelv kommunikációs szerepét gyakorlati szempontból vizsgáljuk, mert a szociálpedagógus alapkészsége a kommunikáció. A jó szociálpedagógus másképpen beszél a kliensekkel, a hozzátartozókkal és a környezettel. Meg kell találnia a közös hangot a kollegáival és az intézményekben dolgozó szakemberekkel, továbbá a döntéshozókkal, a városvezetőkkel. A jól megválasztott kommunikáció nem csupán verbális kifejezésekre, hanem írásos szintre is kiterjed (szakmai jelentések, jegyzőkönyvek, kérvények stb.). A szociálpedagógusi kommunikáció feltérképezése azért tünik lényeges oktatási feladatnak, mert a hallgatókat fel kell készítenünk a hatékony kommunikációra.

A továbbiakban a szociálpedagógus kommunikációjának elméleti kereteit tekintjük át. Napjainkban igen nagy szükség van a hallgatók kommunikációs kompetenciájának fejlesztésére, ehhez a dolgozat második részében kommunikációs gyakorlatokat mutatunk be.

\section{Egy sajátos szaknyelvről}

A szociálpedagógusok nyelve sajátos szaknyelv, a nyelv különleges szelete, nem külön nyelv. „A szaknyelv olyan társadalmi nyelvváltozat, amely intra- és interkulturális nyelvváltozat is egyben" (Kurtán 2010: 13). A szaknyelv ötvözi a nyelv általános sajátosságait a szakmai kultúra sajátos szókincsével, szintaxisával és pragmatikájával. Nyelven kívüli tényező, a szituációs kontextus határozza meg a mondanivalóhoz rendelt nyelvi formákat (Kurtán 2010: 11).

A szociálpedagógusok nyelvét az alábbi kontextusokkal írhatjuk le (Kurtán 2010: 15 nyomán):

1. a nyelvhasználat színtere (tárgyalóterem, gyermekotthon, szakmai megbeszélések, nevelési-oktatási intézmények stb.);

2. különféle beszédhelyzetekben megnyilvánuló tevékenységek (pl. elektronikus levelezés, szakirodalom olvasása, kliensekkel való megbeszélések stb.);

3. a jellemző szövegtípusok (ürlapok, telefonüzenetek, feljegyzések, ajánlások, pályázatok stb.). 
A kommunikáció során használt nyelvhasználat leírható a kommunikációban részt vevők alapján is: szociálpedagógusok beszélgetnek egymással, a társalgás folyhat szociálpedagógus és érdeklődő laikus között is. A szakmai specializáltság mértéke lényegesen eltér a két esetben, mert másként kommunikál egymással két szakember, mint egy szakember és egy laikus, pl. egy szociálpedagógus és a kliens hozzátartozója. A jelentések nem egyformán mutatkoznak meg a két fél számára, más a felkészültségük szintje is. A szakember (esetünkben a szociálpedagógus) és a laikus (pl. a kliens vagy a kliens hozzátartozója) kommunikációjának sikere azon múlik, mennyire közérthetően tudja a szakember átadni a szükséges információt, mennyire tudja a hallgató számára érthetően közölni a szükséges elemeket.

A szociálpedagógusok mint szakmai beszélöközösség olyan szakmai kultúrát képviselnek, amelyben a szakmai háttérismeretek játszanak jelentős szerepet. Az egyes beszélöközösségek nyelvi és nem nyelvi kategóriák alapján is jellemezhetők:

1. a szakmai beszélőközösségnek széles körben elfogadott közös céljai vannak;

2. a közösség tagjai kiépítették maguk között a kommunikáció mechanizmusait;

3. ezeket a mechanizmusokat elsősorban információszerzésre és a visszajelzés biztosítására használják;

4. a közösség egy vagy több müfajt ismer és használ céljai kommunikálására;

5. a sajátos müfajok mellett sajátos lexikája is van;

6. a diskurzusközösség tagjai a konvencióknak megfelelö tartalom- és szövegkezelési tapasztalatokkal, ismeretekkel rendelkeznek (Kurtán 2010: 16.).

A szociálpedagógus szakmai kommunikációjának vizsgálatakor figyelembe kell venni, hogy a szociálpedagógus társadalmi státuszának, szerepeinek összefüggésében, a kommunikációs helyzet összetevői szerint hogyan viselkedik. A szociálpedagógus szakmai nyelvhasználatában interakciónak minősül egy bírósági tárgyalás vagy egy problémás eset megvitatása. A személyközi kommunikáció két vagy több személy között zajlik, pl. szociálpedagógusok beszélgetnek egymással, szociálpedagógus és kliens beszélget. A szervezetek közötti kommuni- 
káció esetünkben azt jelenti, hogy a szociális intézmény kapcsolatban áll más szociális intézményekkel. A szervezeten belüli kommunikáció egy adott szociális intézmény (pl. családok átmeneti otthona, gyermekvédelmi intézmények stb.) belső müködését szabályozza. Minden intézmény kidolgozza a saját kommunikációs szabályait és a müködésükhöz szükséges csatornákat. A szervezetek kifelé irányuló kommunikációját tanulmányozva megfigyelhetjük, hogy a szociális intézmények kommunikálnak más szervezetekkel, pl. önkormányzattal, államigazgatási szervek képviselőivel. A fó cél az intézményt érintő információk gyüjtése, elemzése és feldolgozása, a változások követése. A szociális intézmény kommunikál az ügyfeleivel, az ún. kliensekkel és hozzátartozóikkal. Ebben az esetben a cél az információnyújtás és a hiteles tájékoztatás. A közlésnek igazodnia kell a hallgató tudásszintjéhez, fizikai és mentális állapotához.

$\mathrm{Az}$ interakció másik résztvevője, a befogadó a hallott vagy olvasott szöveget értelmezi a nyelvismerete, háttérismerete és tudása segítségével. Az olvasás vagy a beszédértés sem passzív folyamat, hiszen összeveti a hallottakat vagy olvasottakat eddigi ismereteivel, specifikus információt keres vagy megértésre törekszik. Eközben mozgósítja nyelvi ismereteit, elkülöníti a lényeges és lényegtelen információkat, felismeri a kohézió jeleit.

A szociálpedagógusnak gyakran speciális készségek mozgósítására is szüksége van, ami újabb követelményeket támaszt. Gyakran kell rövid, könnyen érthető mondatokban fogalmaznia, csak a lényeges tudnivalókat közölnie. Bizonyos kitüntetett szerepü információkat sokszor el kell mondania. Sor kerülhet nem verbális közlésformák használatára, pl. képek, adatok, táblázatok szerkesztésére is.

A szociálpedagógus kommunikációját a beszédszándékok alapján az alábbi csoportokba foglalhatjuk (Kurtán 2010: 19 nyomán):

1. Általános kijelentések, tájékoztatások: Az elmúlt évben ... kliens kereste fel intézményünket, ... esettel foglalkoztunk havonta. A ... gyüjtésre ... értékü felajánlás érkezett.

2. Kérések, utasítások, javaslatok, amelyekkel a beszélő (szociálpedagógus) valamely cselekvésre próbálja a hallgatót rávenni Azt tanácsoljuk, hogy, ... Vizsgáljuk meg, hogy ....

3. A szociálpedagógus tevékenységére vonatkozó elkötelezettségek, pl. ígéretek, figyelmeztetés: A helyszíni környezettanulmány alapján megállapítjuk, hogy ... 
4. A szociálpedagógus attitüdjét kifejező megnyilatkozások: $S a j$ nálattal közöljük, hogy... Biztos vagyok abban, hogy ... (ez a gyermek javát szolgálja).

5. A helyzetet megváltoztató megnyilatkozások, pl. kinevezés, felmondás: Önt a mai nappal kinevezem ...

A beszédszándékok érvényesítésekor az üzenet formája szoros kapcsolatban áll a tartalommal. A szakmai kommunikációban ennek különös jelentősége van, hiszen az ilyen tartalmat hitelesen és pontosan kell a kliensekkel közölni, méghozzá oly módon, hogy az számukra is érthető legyen. A szakmai kommunikáció egészen más jellemzőket mutat két szakmabeli, azaz két szociálpedagógus beszélgetése során.

A szociálpedagógus írásbeli kommunikációjában eltérő műfajokat különböztethetünk meg, ám az egyes müfaji sajátosságokat együttesen határozza meg az intézmény és a szakma. Eltérő formában más tartalom jut kifejezésre egy jegyzőkönyvben, egy hivatalos levélben vagy egy pályázati beszámolóban. A múfajok és a szakmai közeg is folyamatosan változik, szakmai kommunikációban is megjelent a fax, az email, sms és az újabb közléshordozók.

A szociálpedagógusok kommunikációjának kérdéskörét dolgozatom alapvetően a szociális intézmények kommunikációs irányelvei alapján közelíti meg (Bisztricsány-Kálmán 2007).

A kommunikáció oktatásához számos kézikönyvet és gyakorlókönyvet találunk (a teljesség igénye nélkül, pl. Cs. Jónás 1998, Bánréti 1998, Fercsik-Raátz 2006, Hajas 2010, Szőke 2005, N. Horváth 2005). Ezek elsősorban középiskolás diákoknak íródtak, feltételezve, hogy a kommunikációs gyakorlatok a középiskolai követelmény részeként jelennek meg. Hiányoznak ezen a területen a szociálpedagógus-szakma követelményeit figyelembe vevő, módszertani következetességet érvényesítő munkák. Jelen dolgozatomban a szociálpedagógus kommunikációját tekintem át, közben - mintegy keresztirányú szempontként - folyamatosan a szociálpedagógus hallgatókra szabott kommunikációs gyakorlatokat mutatok be. Munkám során arra törekszem, hogy használható ötleteket adjak a szociálpedagógus hallgatók kommunikációs készségének javításához.

A szociálpedagógus-hallgatók számára az alapozó képzés egyik tárgya a Kommunikáció. A hallgatók középiskolai éveikben tanultak a kommunikáció alapjairól, így a kurzus folyamán ezekre az ismeretekre lehet építeni. A kurzus során az elméleti ismeretek mellett nagy hang- 
súlyt kap a gyakorlat, a kommunikációs technikák gyakorlása. A kommunikációs gyakorlat során alapvető elvárás, hogy az órák egyéni tapasztalásra és élményre épüljenek, továbbá jó hangulatban teljenek, és aktivizálják a részvevőket.

\section{Kommunikációs gyakorlatok}

\section{Általános kommunikációs képességek}

A kommunikáció nem csupán abból áll, hogy szóban vagy írásban közlünk gondolatokat. Nem pusztán az a fontos, hogy mit mondunk vagy írunk, hanem az is, hogyan. A kommunikáció módján olykor több is múlik, mint a közlés tartalmán.

A szociálpedagógus számára alapvető fontosságú kommunikációs képesség a kapcsolatteremtés, együttmüködés, érvelés, a gyermekekkel való beszélgetés képessége.

\section{1. feladat}

A gyakorlat előkészítéseként a hallgatókkal áttekintjük az egyes stílusrétegekre jellemző nyelvi kifejezőeszközöket. Szövegeket rendelünk a fó típusokhoz, majd a szókészletet, a mondatalkotást és a szövegszerkesztést vizsgáljuk meg.

Ezt követően a hallgatók csoportokban dolgoznak. Minden csoport ugyanazt a témát dolgozza fel. Lesz társalgási, tudományos, publicisztikai, hivatalos és szónoki stílusú szöveg $A$ hajléktalan címmel.

A gyakorlat folytatásaként megbeszélik, milyen volt csoportban dolgozni. Tudtak-e együtt müködni? Kik voltak a hangadók? Hogyan változtak a kommunikációs tényezők?

\section{2. feladat}

Ha a szöveg (beszédmü vagy írásmü) azzal a céllal születik, hogy egy probléma elemzésével, bemutatásával elgondolkodtasson, valamely igazságról igyekezzen meggyőzni a hallgatót (olvasót), akkor az elemzőmeggyőző szövegfajta kerül előtérbe.

Játsszanak el egy jelenetet, amelyben apa és fia beszélgetnek egymással! Mindkettő befolyásolni akarja a másikat.

A jelenet címe: Bálint maga szeretné megválasztani a barátait Játsszák el a jelenetet anya és lánya között is.

A jelenet címe: Borbála maga szeretné megválasztani a barátait 
A metanyelvi eszközök hogyan egészítették ki a verbális közlést? Miért jött létre a kommunikációs helyzet? A jelenetek után vitassák meg, hogyan nyilvánult meg a szereplők véleménye és beszédszándéka a mondataikban, arcjátékukban, hangsúlyozásukban (Bánréti 1998: 22 nyomán).

\section{3. feladat}

Meséljen el egy érdekes történetet! Alakítsa úgy, hogy az egyes részek az alábbi szavakkal kezdődjenek:

Gyorsan...

Halkan...

Azonnal ...

Óvatosan ...

Hirtelen ...

Szerencsére ...

Valójában ...

\section{4. feladat}

A csoport tagjai egy-egy közmondást húznak. A közmondáshoz kapcsolódó történetet kell elmondaniuk, amelyböl a hallgatónak rá kell ismernie a közmondásra. A gyakorlat célja a verbális nyelvi kifejezőkészség fejlesztése, a kreativitás támogatása. A végén közösen értékelik a gyakorlatot, és megbeszélik, melyik volt a legjobb előadásmód, illetve a legjobb történet.

\section{5. feladat}

A csoport tagjai fotókat kapnak metakommunikációs eszközök elemzésére. A képeken híres emberek vagy hétköznapi személyek láthatók. A gyakorlat célja, hogy a hallgatók értelmezni tudják a nem verbális jeleket.

\section{Kommunikáció a kliensekkel}

Ahhoz, hogy egészséges kapcsolat álljon fenn szociálpedagógus és kliense között szükség van különböző alapvető kommunikációs készségekre.

A hallgatás és meghallgatás képességének döntő szerepe van a szakmai sikerben. A hallgatás nehéz; kevesen számítanak elfogadható vagy felkészült hallgatónak. A hallgatás fejlesztése szempontjából aktív és passzív hallgatást különböztethetünk meg (Szabó 1997: 162). Paszszív hallgatásra a szakmai életben ritkán kerül sor, ezért figyelmünket az aktív hallgatásra fordítjuk. A jó hallgató (esetünkben a jó 
szociálpedagógus) képes arra, hogy szabad, elfogadó légkört teremtsen, amelyben az emberek nyugodtan beszélgetnek, nem éreznek semmilyen elutasítást vagy ellenséges attitüdöt. A jó hallgatás legfontosabb előnye, hogy sokkal több információhoz jut a hallgató. A hallgató tud a sorok között „olvasni”, a gesztusokból, elhallgatásokból, szövegösszefüggésekből is értékes következtetéseket tud levonni. A szociálpedagógus képes kitölteni a beszélő által hagyott üres helyeket, fehér foltokat, meghallja azt is, amit a beszélő (kliens) szándékosan hagyott homályban.

A hallgatásra többnyire interaktív: egy kérdés megvitatása során kölcsönösen meghallgatjuk egymást. A szociálpedagógus számára az egyik legfontosabb az információszerző hallgatás (Szabó 1997: 169). Megbeszéléseken, vitákon vesz részt, ezeken jelentős információt szerez. Interaktív kommunikáció során azonban az efféle hallgatás lényege a partner beszéltetése, hiszen ily módon jut a lehető legtöbb több információhoz. Minél több és jobb minőségü információt szerezhet, akár olyat is, melyeket a partner korábban nem szándékozott elmondani. A szociálpedagógusnak célszerü semleges magatartást tanúsítani, nehogy megijessze a klienst kíváncsiságával.

A kliensekkel való kommunikáció során szükség van az ún. „,visszhangzó" vagy empatikus hallgatásra (Szabó 1997: 172). Ez akkor kerülhet elötérbe, ha a kliens szeretné kibeszélni magát, hiszen így könynyebben dolgozza fel konfliktusait. Ezekben az esetekben az empatikus attitüd lehet a kiindulópont, fokozatosan lehet a beszédpartnert a racionális gondolkodás felé terelni.

$\mathrm{Az}$ empatikus hallgatásnak egy másik változata a szakmai problémákhoz kötődik (Fercsik-Raátz 2008: 44). Ilyenkor a partner egy, a számára nehezen megoldható szakmai problémát mesél el, és segítséget vár benne. Az efféle konfliktusok megoldását segíti a szupervízió is.

A hallgatás során minden esetben elengedhetetlen a visszajelzés. A jó szociálpedagógus türelmes hallgató. A beszélőnek hagy időt, hogy kifejezze gondolatait. Nem szakítja minduntalan félbe, hanem arcjátékkal, egy-egy közbevetett szócskával igazolja vissza szavait. Szükség esetén kérdésekkel segíti a beszélöt.

\section{1. feladat}

A sikeres kommunikációhoz helyesen kell felmérni a megbeszélések időigényét. Mit tesz akkor, ha a kliens már lezárt témákkal hozakodik 
elő, és nem tudnak érdemben tárgyalni az aktuális kérdésekröl. Hogyan, milyen szavakkal tudja a beszélgetéseket továbblendíteni?

\section{2. feladat}

Az időtartam mellett lényeges a megbeszélés időpontjának és helyének megválasztása. Mikor (a tervezett időpont elött mennyivel) közölné a nappali otthon klienseivel és hozzátartozóival, hogy kirándulásra készülnek?

\section{3. feladat}

Az egyéni vagy csoportos kommunikációs formát elsősorban a téma határozza meg. A magán nyugdíjas-otthonban szobacserék lesznek. Hogyan közölné a hírt az intézmény lakóival?

Az egyházi nyugdíjas-otthonban épületfelújítási munkák kezdődnek. A kellemetlenség mindenkit érint majd. Ki és hogyan közölje ezt a lakókkal?

A hajléktalanoknak kevesebb adag ebédet tudnak adni. Hogyan közölné az érintettekkel?

\section{4. feladat}

Figyelje meg saját hallgatási szokásait! Legyen türelmes hallgató! Hallgatás közben figyeljen a metakommunikációjára is. A magánéletben mikor él az empatikus hallgatás eszközével?

\section{Kommunikáció a hozzátartozókkal}

A hozzátartozókkal történő kommunikáció legfontosabb eleme, hogy az ellátott számára a családdal való kapcsolat létfontosságú.

\section{1. feladat}

Intézménye egyik ellátottjának családja érdeklődik családtagja iránt. Játsszák el a beszélgetést, vagy írják le a szöveget!

a) levélváltás

b) telefonbeszélgetés

c) találkozás

\section{2. feladat}

A téma: az intézményben lakók és a hozzátartozók számára tervezett közös programot beszélnek meg. Alakítsanak csoportokat. és játsszak el a jelenetet! 


\section{Kommunikáció a környezettel}

A környezet jelen összefüggésben mindazokat a személyeket és hivatalos szerveket jelenti, akik és amelyek az adott intézmény közvetlen közelében találhatók és/vagy azzal müködése során munkakapcsolatban vannak (Bisztricsány-Kálmán 2007: 16).

A környezetet folyamatosan tájékoztatni kell az intézményben lakók munkájáról és életérool. Az intézmények arra törekszenek, hogy beilleszkedjenek a város életébe. Ennek a ténynek a kommunikációs üzenete az, hogy az intézmény valóban része az adott (lakó)közösségnek.

\section{1. feladat}

Intézménye idén is megrendezi a hagyományos karácsonyi koncertet. A hangversenyen fellép az intézmény énekkara, valamint vendégek is érkeznek. Fogalmazza meg a fenti hírt egy szórólap, plakát és a helyi napilap számára.

\section{2. feladat}

Gyüjtsön össze olyan alkalmakat, amikor hosszabb ideig, több ember előtt beszélt.

\section{3. feladat}

Intézményvezetőként dolgozik, és az intézményben az elmúlt év során felújítási munkálatok folytak. A munka nehéz körülmények között folyt.

a)Számoljon be az elmúlt év nehézségeiről a helyi lap riporterének.

b)Köszönje meg a kollégák munkáját és kitartását az évzáró ünnepségen.

\section{4. feladat}

Előadást kell tartania az intézményében folyó projektről. Érzékeli, hogy a közönség figyelme lankad. Milyen fogásokkal élne, hogy újra magához ragadja a hallgatóság figyelmét?

\section{5. feladat}

Felkérték, hogy középiskolásoknak tartson előadást. Hogyan építi fel a közlendöjét? Készítsen vázlatot!

Témák:

a)Nincs veszélytelen kábitószer 
b) Az AIDS-röl fiataloknak

\section{6. feladat}

A drogrehabilitációs intézet lakóival fákat ültettek a városban. A városlakók is bekapcsolódtak az ültetésbe. Számoljon be az eseményről a helyi újságban.

Az írásbeli kommunikáció sikeréhez hozzájárul a helyesírási szabályok ismerte is. Az írásbeli kommunikáció fejlesztéséhez szükséges a helyesírási tudnivalók ismétlése és a helyesírás gyakorlása is.

\section{Összegzés}

A kommunikáció a szociálpedagógus munkaeszköze, épp ezért a hallgatóknak hasznosak a kommunikációs készségeket fejlesztő tréningek. Gyakorolniuk kell mind a szóbeli, mind az írásbeli kommunikációs müfajokat. A szociálpedagógus kommunikációjáról kapott kép felhasználható a hallgatók felkészítésében, hiszen a hallgatók körében sok bizonytalanság tapasztalható a megfelelő kommunikációs forma megválasztásában. A jelenségkör teljes feltérképezéséhez azonban további kutatásokra is szükség van: legfontosabb feladatnak az írásbeli és szóbeli anyaggyüjtés tünik. Ezt követően az egyes színtereken belül tapasztalt különbségek és hasonlóságok alapján még célzottabb felkészítést tudunk nyújtani a jövő szakembereinek.

\section{Irodalom}

BÁNRÉTI Zoltán (1998): Kommunikálj! Kommunikációs tréningek középiskolások számára. Budapest. Korona Nova Kiadó.

BISZTRICSÁNY Andrea - KÁLMÁN Zsófia (2007): A szociális intézmények kommunikációs irányelvei. Kommunikáció a kliensekkel, hozzátartozókkal, a környezettel. In: Horváth Attila (szerk.): Szociális és gyermekvédelmi szabályozók. http://www.hfk.hu/docs/070327/kom.pdf letöltés dátuma: 2011. október 25.

Cs. JóNÁs Erzsébet (1998): Mindennapi kommunikációnk. Nyíregyháza. Bessenyei György Könyvkiadó.

FERCSIK Erzsébet-RAÁTZ Judit (2008): Kommunikáció és nyelvhasználat. Budapest. Nemzeti Tankönyvkiadó. 
HAJAS Zsuzsa (2010): Kommunikációs gyakorlatok középiskolásoknak. Debrecen. Pedellus Tankönyvkiadó.

KURTÁN Zsuzsa (2010): Szaknyelv és szakmai kommunikáció. In: Dobos Csilla (szerk.): Szaknyelvi kommunikáció. Budapest-Miskolc, Miskolci Egyetem-Tinta Könyvkiadó 11-22.

N. Horváth Béla (2006): Gyakorlati kommunikáció. Budapest. Pont Kiadó.

SzABÓ Katalin (1997): Kommunikáció felsőfokon. Budapest. Akadémiai Kiadó.

SzABÓ Katalin (2001): Kommunikáció felsőfokon. 2., bővített kiadás. Budapest. Akadémiai Kiadó.

SzŐKE-Milinte Enikő (2005): A kommunikációs kompetencia fejlesztése. Piliscsaba. PPKE BTK. 

Szociálpedagógia - színterek 



\title{
Szilágyi Györgyi ${ }^{9}$ - Gombik Judit ${ }^{10}$
}

\section{EGYHÁZI SZOCIÁLIS SZEREPVÁLLALÁS A SZOCIÁLIS ELLÁTÓ RENDSZERBEN}

\author{
THE ROLE OF THE CHURCHES \\ IN THE SYSTEM OF SOCIAL ASISTANCE
}

\begin{abstract}
In the period after the democratic transformation churches as institutions re-interpreted their role in the society in the field of politics, education and philantropic activities. This process of redefining of the social role had an effect on the recognition of the churches in Romania and on the social expectations toward these churches as well. As the instrumental functions come to the front the opinion gathered ground that the churches should be some sort of social service institutions. This fact is considered by many people, who belong to the inner circles of the churches as a devaluation and a crisis of the whole institution and they think that this new perception means the weakening of the traditional and authentic functions of the churches. This paper examines these processes in Romania.
\end{abstract}

\section{Az egyházak szerepvállalása}

A történelem folyamán az egyházban mindig jelen volt a karitatív tevékenység .Az egyház karitatív tevékenységei azért is népszerűek, mert tradíciójából kifolyólag a hitélet és a „felebarát segítése” szorosan öszszefonódott mindig. Meg kell azonban jegyezni, hogy az egyház nem csak erkölcsi és humanitárius okok miatt foglalkozik a szociális problémákkal, hanem dogmatikai alapelveiböl kiindulva, fö célkitüzését tartja szem elött, ami nem más, mint a megváltás.

\footnotetext{
${ }^{9}$ dr. Szilágyi Györgyi tanszékvezető egyetemi professzor, Partiumi Keresztény Egyetem, Bölcsésztudományi kar

${ }^{10}$ drd. Gombik Judit egyetemi adjunktus, Partiumi Keresztény Egyetem, Bölcsésztudományi kar
} 
A dogmatikai alapelvekre való hivatkozások mögött azonban jól megfigyelhető a mindenkori társadalmi követelményekhez való alkalmazkodás törekvése. A római katolikus egyház szociális tanításában például a II. Vatikáni zsinaton új egyháztudat jelenik meg. Az egyoldalú klerikus egyházról a népre, a világi hívőkre tevődött át a hangsúly. A zsinat elismerte a „földi dolgok jogos autonómiáját”, vagyis azt, hogy az emberi „közösségeknek is megvannak a saját törvényeik és értékeik, amelyeket az embereknek lépésről lépésre felismernie, alkalmaznia és tanítania kell.”

A II. Vatikáni zsinat után, a katolikus társadalmi tanítás a pápák szociális enciklikáiban fejeződött ki. A sort a Rerum Novarum (1891) nyitotta meg, ezt követte 1931-ben a Quadragesimo anno. XXIII. János pápa Mater et Magistra (1961) enciklikája után, VI. Pál pápa Populorum progressio (1967) címü körlevele következett. II. János Pál több szociális körlevelet adott ki. 1981-ben a Laborem excercens kezdetüt, 1987-ben a Sollicitudo rei socialis-t, 1991-ben pedig, a Centesimus annus-t.

A szoros értelemben vett társadalmi kérdésekkel foglalkozó pápai körlevél szerint a katolikus egyház társadalmi tanítása 4 alapelvre épül: az egyén- illetve emberközpontúság, a szolidaritás, a szubszidiaritás és a közjó elvére.

1. Az emberközpontúság azt hangsúlyozza, hogy az egyedüli alapvető érték és kritérium az ember és az emberi méltóság.

2. A szolidaritás olyan társadalom-szervezeti követelmény, amely a legönállótlanabb és legelesettebb rétegek felemelésére is kiterjed. Jog és kötelezettség a felelösségben való osztozásra a társdalom minden szintjén.

3. A szubszidiaritás elvének az a lényege, hogy amit az egyes ember önmaga megvalósíthat, azt egy közösség nem vehet el tőle, éppígy mindazt, amit egy kisebb közösség képes önmagában végrehajtani, azt nem ragadhatja magához egy nagyobb csoport vagy éppen az állam.

4. A közjó elve szerint a társadalmi pluralitás önmagában nem szavatolja mindenki javát. Az egyes társadalmi alakulatoknak ahhoz, hogy megvalósíthassák céljukat, szükség van támasznyújtó segítségre, az állam koordináló tekintélyére.(Ladányi, Papp, Tökéczki, 1998) 


\section{Egyház és diakónia Romániában}

A rendszerváltás elötti negyven év alatt megvalósult erőltetett modernizáció Romániában is igen nagymértékben együtt járt a hagyományos közösségek fellazítására irányuló pártállami törekvésekkel. Ehhez kapcsolódott a szekularizáció politikai eszközökkel is gyorsított folyamata, amely szintén a hagyományos közösségek felbomlása irányában hatott ez által megfosztva a közösségeket az önszervező, önsegítő feladatok elvégzésének lehetőségétől. A múlt rendszerben ideológiai okok miatt szegénységről, analfabetizmusról, netán hajléktalanokról hivatalosan nem volt szó, annak ellenére, hogy a jelenség létezett.

„Az állam arra törekedett, hogy az egyházat - mint olyan intézmény, ami segíthetne a szociális problémák megoldásában - a társadalom peremére szorítsa és nem kívánta, hogy bármilyen formában és mértékben részt vegyen a közéletben és a politizálásban.”(Bene, 1998, 14. old)

Az egyház teljesen az ideológiai harc célpontja lett. Az általános kollektivizáláskor az egyház minden földtulajdonát államosították, és az épületek is ugyan erre a sorsra jutottak. Az egyházi tevékenység az iskolákból a templomokba szorult. Az állam megfosztotta az egyházat, a közmüvelődést és a nemzeti kultúrát szolgáló intézményeiktől. Egyetlen felekezet sem nyithatott, vagy tarthatott fenn oktatási intézményeket, kivéve azokat melyek saját személyzetüket készítették fel.

A különböző alkotmányos elöírások arra utaltak, hogy az egyházak szerepe a társdalomban és az államban jelentősen átértékelődött, megtürt státuszba került, sőt sokszor saját jogszabályaikat sem tarthatták fenn. Az ortodox és a többi egyház közötti megkülönböztetés mellett azt is meg kell említenünk, hogy a görög katolikus egyházat betiltották.' 89 előtt az egyházak - kivétel nélkül - nagy veszteségeket szenvedtek minden vonatkozásban, mégis mint viszonylag önálló intézmények be tudták tölteni küldetésüket: hitük és híveik megőrzését. (Varga, 1996)

Ilyen körülmények között is az egyházhoz való tartozás és a vallási értékek maradtak azok az alapvető civil társadalmi elemek, amelyek mindvégig megőrizték autentikus közösségformáló szerepüket. A vallás alapvető funkciókat töltött és tölt be a helyi közösségek életében. Annál is inkább jelentős volt és maradt a vallás és az egyház szerepe, mivel esetünkben olyan vallási közösségekről van szó, amelyek önazonosság 
tudatukat a kissebségi helyzet szorító körülményei között kellett megvédelmezniük és újra termelniük.

A kommunizmus bukása után a tradicionális egyházak karitatív intézményei újra kezdték aktivitásukat, elsődleges célként, az állam által beteljesítetlen szociális funkciók pótlását megjelölve. Az egyház karitatív szervezeteinek anyagi alapját az adományok valamint különböző jövedelmező tevékenységek és szolgáltatások teszik ki. A különböző felekezetek, szociális tevékenységeik által arra törekednek, hogy megoldásokat találjanak a szociális különbségek csökkentésére.

A gyökeres társadalmi, politikai és gazdasági átalakulások súlyos nehézségeket, a társadalom életét megrendítő válságokat vonnak maguk után. Az átmeneti kornak áldozatai a betegségtől, a magánytól, a létbizonytalanságtól, a megélhetési gondoktól, a jogfosztottságtól, a hajléktalanságtól, a munkanélküliségtől és a kitaszítottságtól szenvedő sok-sok ember. A nyolcvanas évek végéig fenntartott szociális biztonsági háló leomlása akkor is aggasztó, ha indoklására vannak gazdasági és más érvek, hiszen fedezetét nagyrészt csak hitelekből lehetett megteremteni, és sok tekintetben csak látszólagosnak bizonyult.

Hazánkban egyik legsúlyosabb probléma a növekvő szegénység, amit a nélkülözők számának rohamos növekedése jellemez. A pártállami rendszerben létrejött alapvető szociális feszültségek nem csökkentek, sőt tovább növekedtek. A súlyos társadalmi egyenlötlenségeket eredményező folyamatokat nem sikerült megállítani, sőt azok a piacgazdaságra való átmenet során tovább mélyültek, és újabb formákat öltöttek, jelentősen növelve a szakadékot egy hirtelen és aránytalanul meggazdagodott szük réteg és a megélhetés nehézségeivel egyre inkább küszködő nép között.

Az egyháznak különös odaadással kell gondoskodnia a szegényekről, a hátrányos helyzetbe kerültekről, az elnyomottakról. Ez az egyház társadalmi útmutatásának egyik legfontosabb szempontja. Az egyháznak az egyének jogainak védelmében elsősorban a deprivációra kell tekintettel lennie. A peremre szorult tömegek, akik semmilyen saját eszközzel nem rendelkeznek érdekeik megvédésére, kizárólag az egyházra és az államra támaszkodhatnak. Az utóbbi években egyre nagyobb figyelem irányult az állami és nem állami szereplők közötti együttmúködés lehetőségeire és új formáira. A kormányok egyre kisebb mértékben képesek és hajlandók a közszükségletek kielégítéséről gondoskodni, miközben a társadalmi struktúrákban bekövetkezett változások - például a családok összetételének változása, a lakosság gyors 
öregedése, a munkanélküliség általánossá válása - rendkívüli pénzügyi és emberi erőforrásokat igényelnek. Sok ismert kutató elsősorban az állami feladatvállalás kudarcával magyarázza a nonprofit szereplők, egyházak egyre erőteljesebb színrelépését, elsősorban a szociális és az egészségügyi ellátások területén, mások a piaci kudarcoknak tulajdonítják ezt a jelenséget.

\section{Szociális intézmények a Királyhágó-melléki Református Egyházke- rületben}

Jelen tanulmány során be szeretnénk mutatni néhány szociális segítő munkát végző egyházi és világi karitatív szervezetet, egyesületet. Három olyan szervezetet, amelyek Nagyváradon, illetve a megyében igen nagy fontosságú és horderejü tevékenységet folytatnak, s ezáltal jelentős részt vállalnak az elesettek, a szociálisan rászorultak nyomorának, szenvedéseinek enyhítésében. Az egyik a Királyhágómelléki Református Egyházkerület Szociális Napközije, amely a hátrányos helyzetü családokból származó gyermekek beilleszkedésének elősegítését tüzte ki célul. A másik Lorántffy Zsuzsanna Református Egyházi Központ, amely időseknek, nyugdíjasoknak nyújt lelki segélyt,étkezési lehetőséget A harmadik a Szentannai Cigánymissziós Központ, mely a roma közösségek integrálását célozta meg.

\section{A Királyhágómelléki Református Egyházkerület Szociális Napközije}

A napközi - mint gyermekvédelmi intézmény - 1994 óta szociálisan hátrányos helyzetű kisiskolásoknak tanulási-, beszédtanulási-, magatartási-, valamint kapcsolati zavarainak kezelésében és szociális problémáinak kiküszöbölésében nyújt segítséget. A tanulók árvák, akiket rokonok nevelnek, félárvák, csonka vagy nagycsaládból, létminimum alatt élő családból, illetve roma családból származnak. A családok 70\%-a három vagy több kisgyermeket nevel.

A Napközi délutáni programmal müködik 12-18 óra között, és oktatási feladatok ellátásával (házi feladatok elkészítése), tanulmányi lemaradások pótlásából áll. Az ismeretek elsajátítása differenciált módszerekkel történik. A Napközi tevékenysége szociális segítségnyújtással, logopédiai foglalkozásokkal és hitoktatással is kibővül.

A napközibe 20 gyermek jár, életkoruk 6-11 év és mindannyian az általános iskola alsó tagozatának tanulói. A gyermekeket a város kü- 
lönböző iskoláiból toborozzák. A napközi vállalja, hogy a hagyományos oktatási, nevelési intézményekben folyamatosan alulteljesítö, fokozódó beilleszkedési nehézségekkel küzdő gyerekek indulási hátrányait kompenzálja. Céljának tekinti, hogy megerösítse a gyerekeknek a felnőttek iránt megrendült bizalmát. Fontosnak tartja a vallási, etikai toleranciát, a humanitásra, szociális érzékenységre való nevelést. Tevékenységrendszerével nyitottabbá teszi a gyermekeket a világra, elindítja a szocializálódás rendkívüli sok tapintatot és megértést igénylö útján.

A személyiségformálás alapja a biztonságos, derüs, családias légkör. Ezért a napközi funkciójához tartozik a család támogatása, erősítése is. Olyan müsorokat szerveznek, melyeknek témáját előzetesen s szülök határozzák meg. A feladat, hogy a hátrányos helyzetü gyermekek szüleit megnyerjék az intézményes nevelés elfogadására. Időszakonként élelem és ruhaosztásra kerül sor (melyet az Egyházkerület bel- és külföldi adományokból fedez). A nevelők rendszeresen járnak családot látogatni, anyák, apák, nagyszülök jönnek el beszélgetni, tanácsot kérni.

A napközi olyan cselekvési programot dolgozott ki, amely alapján képessé válik az együttmüködésre más intézményekkel, ideértve a kölcsönös segítségnyújtást. A gyermekek nehéz szociális körülményei miatt, többnek a Napköziben elfogyasztott ebéd az egyedüli biztos napi élelemforrás. Ennek oka a szülők szegényes, nehéz anyagi helyzete, valamint deviáns életmódja. A gyermekcsoport étkeztetését a Királyhágómelléki Református Egyházkerület Missziói Ügyosztálya vállalta fel. A gyermekek ebédjét a nagyváradi Lorántffy Egyházi központ étkezdéjéből szállítják a Napközibe.

A napközi nevelőgárdája három személyből áll: egy szociálpedagógus (intézményvezető), egy hitoktató, részmunkaidős és egy kisegítő-nevelő.

\section{Lorántffy Zsuzsanna Református Egyházi Központ}

A központ 1997 augusztusában jött létre melynek diakóniai programja októberben kezdődött. Aktivitásának kezdetén 8 ebédet szállítottak házhoz a rászorulóknak, majd az idő során ez a szám lassan növekedett. 1999-ben a kisnyugdíjasok mellett már a nagycsaládosoknak is biztosítottak ingyenes ebédet, később viszont anyagi gondok miatt 2000 márciusában megszüntették ezt a szolgáltatást.

Jelenleg 60-70 ebédet biztosítanak. Egy ebéd ára, a rászorultság mértékétől függően, 12 lej. A szolgáltatást 20-25 nyugdíjas veszi igénybe, akik közül 20 személynek házhoz szállítják az ebédet. Továb- 
bá nyolc 3-4 gyerekes család, a Lorántffy középiskola bentlakó diákjai, valamint a Szociális Napközi étkezik a Lorrántffy Központban.

A Központnak 10 alkalmazottja van:, 1 előkönyvelö, rendezvényszervező, 1 igazgató beszerző, 1 gépkocsivezető, 4 szakács, 1 takarító és 2 éjjeliőr. Az alkalmazottak közül öten rendelkeznek munkakönyvvel, míg a többiek nyugdíjasok,önkéntesek A központ pályázatokból, az egyházkerületek, egyházközségek természetbeni adományaiból, a termek és a vendégszobák kiadásából tartja fenn magát és fedezi költségeit.

\section{Szentannai Cigánymissziós Központ}

A szentannai cigánymisszió kettős feladatot lát el. Egyfelől előkészíti a társadalmat a romákkal való együttélésre, másfelől konkrét missziót lát el a romák között. E kettősségböl kifolyólag a központnak két alaptevékenysége van: Egy romákból álló vezetőség segítségével megpróbál egy önálló roma közösséget létrehozni; Szociális problémákat old meg.

A feladatot kidolgozandó a Királyhágómelléki Református Egyházkerület felkérte a szentannai roma közösséget egy vezetőség megalakítására. A szociális problémák tekintetében a megoldást egy öt pontból álló elképzelésben látták.

a) közösségfejlesztés

b) oktatás

c) közegészségügy

d) kommunikáció

e) szociális biztonság

A roma közösség szervezése és a szociális problémák megoldása egy időben történt, összhangban és kiegészítve egymást. A Szentannai Cigánymissziós Központ a nagyobb hatékonyság érdekében, úgy döntött, hogy munkáját nem csak helyi szinten, Nagyváradon, hanem a közösségen belül, Szentannán is végzi. Ezért ott is létrehozott egy kirendeltséget melyben a roma komisszió tevékenykedett.

\section{KÖZÖSSÉGFEJLESZTÉS: önszervezödés, kultúra, munkapiac}

a) önszerveződés:

- A Központ úgy gondolta, hogy a roma szervezetek programjainak, kezdeményezéseinek támogatása fontos lépés lenne. Ezáltal a romák képesek lennének saját közösségükben pozitívan hozzájárulni problémáik megoldásához.

b) kultúra: 
- A Központ úgy gondolta, hogy az egyedi roma kultúra megismertetése és előadása fontos feladat.

- A Központ egy hiányosságot pótolt azzal, hogy egy kiállító termet hozott létre mely a roma szokásokat és kultúrát mutatta be. A kiállító teremben roma származású festők munkái, roma nyelvü könyvek, a hagyományos roma foglalkozások kellékei, használati tárgyai (fafaragás, fonás, ezüstmüvesség stb.), a romák mindennapi életét bemutató fotókiállítás stb. lesz megtekinthető. A kiállító terem hozzájárulhat ahhoz, hogy megváltoztassa az évek során kialakult elöítéleteket a romákkal szemben. A Központ látogatásokat szervez különböző korú iskolacsoportoknak, ahol a látogatók a vizuális élményeken kívül, történelmi és a jelenlegi helyzetet bemutató információkkal is gazdagodhatnak.

c) munkapiac:

- A Központ egyik elsődleges elvi feladata felkarolni és ösztönözni a szociális napköziben lévő roma gyermekeket arra, hogy magasabb képesítést szerezzenek, feltételezve azt, hogy a roma fiatalok, így jobban alkalmazkodna a munkapiac változásaihoz és kifizetődőbb munkát találnak maguknak.

- Az oktatási program 10-15 év múlva válik eredményessé, így jelenleg a romáknak próbálnak segíteni az elhelyezkedésben.

- Olyan tervek kidolgozása melyek segítik a romákat abban, hogy a jövőben munkát találjanak maguknak.

- Támogatni a hagyományos roma foglalkozásokat üző romákat abban, hogy jobb körülmények között, hatékonyabban végezhessék munkájukat, minél több személyt bevonva aktivitásukba.

\section{Segítő kapcsolatok kibontakozása és működése a római katolikus egyházban (a nagyváradi Caritas Catolica példáján)}

A Caritas Catolica a római katolikus egyház által végzett segítő tevékenység egyik legfontosabb intézményes formája. A szervezet világszinten jelenleg hat programot valósít meg, amelyek Latin Amerikára, a Közel Keletre, Közép Európára, Kelet Európára, Afrikára és az Amerikai Egyesült Államokra terjednek ki.

Nyugat Európában a Caritas a két világháború közötti időszakban alakult meg, amikor az egyházi segítő kapcsolatok fejlesztése iránti társadalmi szükséglet nyilvánvalóvá vált. Kelet Európára való kiterjesz- 
tését azonban akadályozta a kommunizmus uralomra kerülése. A rendszerváltást követően a Caritas megkezdte tevékenységét Közép- Kelet Európa országaiban is.

Romániában a Caritas Konföderáció közvetlenül 1989 után kezdett el müködni. 1995-től kezdve teljes jogú tagjává vált az Európai és a Nemzetközi Caritas Konföderációnak. Tizenkét területi szervezettel rendelkezik, amelyek közül a legfontosabbak a gyulafehérvári, nagyváradi, temesvári, szatmári, kolozsvári, jászvárosi és bukaresti szervezetek. Országos szinten tevékenységének legfontosabb területei: a gyermekvédelem, a fogyatékkal élő segítése, egészségügyi programok, az anyagilag rászorultak támogatása, valamint mezőgazdaság-fejlesztési projektek.

A Nagyváradi Római Katolikus Egyházmegye keretében müködő Caritas szervezet 1990. március 20-án alakult meg, melynek székhelye a római katolikus püspökség szomszédságában van. A rendszerváltást követő években ,sorra jöttek a külföldi támogatók, hiszen leginkább csak egy alapra, az egyházakéra alapozhattak. A külföldi támogatók, idővel arra ösztönözték a helyi segítőket, hogy egy struktúrált szervezetté váljanak, így lassan a nagyváradi egyházmegyében is intézményesült a Caritas. A kezdeti nehézségeket áthidalva, íme elmondhatjuk, hogy több mint 22 év alatt struktúrálódott és megerősödött szervezetünk. Fokozottan kiépült a medikális vonal, az idősgondozás, a szociális- és a gyermekprogramok, illetve a fogyatékos gondozás.”Jelenleg a szervezet tevékenységei a következő programokon belül müködnek:

Az egészséggondozási program három szinten müködik:

a) orvosi rendelő: A Caritas politlinikán általános orvosi rendeléstől számos szakorvosi konzultációig sok mindent elvégeznek (pl. gyermekgyógyászat, pszichológia, nőgyógyászat, fogorvosi rendelö, ultrahangos vizsgálat stb.). gyógyszertár:

b) A Caritas-gyógyszertár fontos részét képezi a betegek szolgálatának. Itt elsősorban az orvosi rendelő betegei juthatnak kedvezményesen gyógyszerekhez, de vallási és nemzetiségi külömbség nélkül megpróbálnak segíteni a kisnyugdíjasokon, rokkantakon, munkanélkülieken, utcagyerekeken, és hajléktalanokon.

c) otthoni idős betegápolás és gondozás: e program célja, hogy az időseket otthoni „,családi” keretek között gondozzák, kiküszöbölve azt, hogy kiszakítsák öket megszokott környezetükből. 1997ben PHARE támogatással kezdődött el ez a tevékenység, mely 7 
beteggondozói központot müködtet az egyházmegye területén (Nagyvárad, Margita, Élesd, Belényes, Szalonta, Tasnád, Mihályfalva), így havonta mintegy 400 beteget látnak el.

\section{Idösgondozás}

A Szent Márton idősotthon Szöllösön, Várad külvárosában müködik, ahol nemcsak kisjövedelmü vagy jövedelem nélküli időseket fogadnak, hanem olyanokat is, akik nyugdíjuk fejében kapnak teljes ellátást. Jelenleg 42-en élnek itt idősek, akikről 15 munkatárs gondoskodik: 1 orvos, 2 asszisztensnővér, 10 gondozó, ápoló, 2 konyhai alkalmazott, és egy vezető, igazgató szociális munkás végzettséggel. A gondozottak fenntartására szánt egy havi összeg (1500 lej), melyből 200 lej állami támogatás, 100 lejt a Caritas fedez, a fennmaradó összeget a bentlakók fedezik.

Az intézményt, jelenlegi formájában 2000. áprilisában szentelték fel, több idős ember számára teremtve otthont és biztonságot. Az öregotthon 1994 óta müködik, 1996-2000 között felújították és egy emelettel kibővítették. A betegek hitvallásuk szerint lelkigondozást is kapnak. Az otthonnak kápolnája is van, melyet a mallersdorfi ferences nővérek rendeztek be. A közeljövőben egy idősklub beindítását is tervezik, annak érdekében, hogy még színesebb és változatosabb legyen az otthon programja.

\section{Szociális és gyermekprogramok}

Elsősorban élelmiszercsomaggal segítenek havonta 120 rászoruló nagycsaládon, amelynek a helyzetét környezettanulmány révén állapítják meg. Év elején készítik a felméréseket, de ha az év többi napján újabb kérésekkel fordulnak a Caritashoz, abban az esetben is felmérik a család szociális hátterét, hogy valóban azok a családok kapjanak élelmiszert, akik a legrászorultabbak is.

Itt említhető az a tevékenység, mely a nevelőintézetbe került fiatalokat támogatja. Elsősorban ünnepek alkalmával (Karácsony és Húsvét) segélycsomag akciókat szerveznek főleg a fiatal elítéltek számára

Egy szociális konyhát is müködtet a nagyváradi Caritas, mely naponta kb. 200 személynek biztosít meleg ételt.

Ami a gyermekprogramokat illeti, először is szükséges megemlíteni azt a programot, mely egy roma falu diákjait támogatja.

A gyermekvédelem területén dolgozták ki azt a programot is, mely elsősorban az árva gyermekeknek, a minden esély nélkül kallódó utca- 
gyerekeknek, a gyermekotthonból kikerülö, lakással és munkával nem rendelkező fiataloknak nyújt majd biztonságot, munkát és nem utolsó sorban szeretetet. A szociális központ Szentjobbon nyitotta meg kapuit, mely egy széleskörű programmal latja el a rászorulókat: oktatási központ, elméleti és gyakorlati képzés, mezőgazdasági tevékenység, ifjúsági ház, otthon 8-10 árva kisgyermek és gondozóik számára. A központ a gyerekeknek nemcsak otthont akar teremteni, hanem gondoskodni szeretne megfelelő családi körülményekről, színvonalas képzésről, melynek segítségével biztosítaná és elősegítené jövőbeni érvényesülésüket, valamint beilleszkedésüket a társadalomba.

\section{Sérülteknek nyújtott támogatás}

2000 áprilisában egy újabb programmal gazdagodott a nagyváradi Caritas tevékenysége, a B.A.C.H. irodával. Az iroda sérült embereken kíván segíteni különböző módon: tanácsadás, információk átadása, az elöírt jogok ismertetése, protézisek és egyéb segédeszközök beszerzése. Havonta mintegy 18-20 rászoruló keresi fel az irodát.

Ezen belül egy szülöi önképző csoport is müködik (havi rendszerességgel) sérült gyermeküket gondozó szülők számára, annak érdekében, hogy a szülök minél több információt kaphassanak és hogy megvitassák az aktuális nehézségeket. A problémák megoldása érdekében, szakemberek is segítenek (pszichológus, jogász, orvos), így még több hasznos információt tudhatnak meg az érdeklődők. A Schijndel-i Caritas már több alkalommal támogatta a nagyváradi Caritast elektromos kerekes székekkel mozgássérült gyerekek számára.

\section{Következtetések}

Az 1989-ben megnyílt szabad cselekvési lehetőség esélyt adott az egyházaknak arra, hogy szerepvállalásaikban alkalmazkodjanak a modernkor társadalmi követelményei, elvárásai által meghatározott feladatrendszerekhez. A rendszerváltás korszakváltást hozott az egyházak életében is. Azóta folyamatosan nő a hitüket komolyan vevők, a közösségteremtők, a kereszténységet nyilvánosan is képviselők száma.

A rendszerváltást követő időszakban az egyházak, mint intézmények, újraértelmezték társadalmi szerepvállalásukat a politikum, az oktatás valamint a karitatív tevékenységek terén is. „Az egyházak közéletünk új szereplőivé váltak. Egyesek ebben a demokrácia győzelmét 
látják. Mások a megszokott viszonyok változásától, talán a régmúlt visszatérésétől félnek. Mint a tömött buszban egy új felszálló, az egyházak nyilvános szerepe is ütközésekkel, konfliktusokkal jár” (Tomka, 1995.)

A külföldi kapcsolatok kiépülése hatást gyakorol a romániai egyházak társadalmi elfogadottságára, az irányukban megfogalmazott társadalmi elvárásokra is. Az instrumentális funkciók előtérbe kerülése következtében mindinkább teret nyerhet az a vélekedés, amely az egyházat elsődlegesen valamiféle szociális szolgáltató intézménynek tekinti. Ezt a tényt az egyházak belső köreihez tartozók közül sokan hajlamosak egyoldalúan egyfajta értékvesztésként, válsághelyzetként, az egyedül autentikusnak tekintett hagyományos egyházi funkciók hatékony betöltésének gyengüléseként értelmezni.

Az egyházak számos szociális intézmény létrehozását kezdeményezték. Tették ezt azért, mert szociális szerepvállalásukat akarták teljesíteni, de azért is, mert a szociális segítségen keresztül is közvetíteni akarják az egyházi értékeket. Felvetődik a kérdés, hogy mennyire egyeztethető egy szociális intézményben az egyházi szellemiség és a tudományos szakmaiság. Az egyházi karitatív szervezetek csak akkor müködhetnek hatékonyan, ha megfelelő szakembergárdával rendelkeznek. A szociális szféra tudományai viszont nem mindig összeegyeztethetőek az egyház által képviselt szellemiséggel, ami konfliktusokat szülhet. Ezért is gátolja számos egyházi szociális intézmény hatékonyságát, hogy a megbízott szakemberek nem ,a Biblia szemszögéből”, hanem a szociológiai, orvosi kutatások eredményeinek perspektívájából közelítik meg a szociális problémákat. Ilyen esetekben az egyház úgy érezheti, hogy az illető intézmény feletti ellenőrző funkciója csorbát szenved.

A külföldi tapasztalatok, a hazainál számottevően jobb eredményekre vezető tevékenységi formák kimerítő leírásával, mindmáig adós a hazai szakirodalom. Ezt a munkát az elkövetkezendő években lehet majd elvégezni. Van azonban néhány gyakorlati eredmény, amelyekre érdemes felhívni a figyelmet. Nincsen ugyanis a fejlett országoknak olyan pozitív tapasztalata a szociális szférában, melyet - a szükséges feltételek megléte esetén - ne lehetne nálunk is alkalmazni. De ehhez elsősorban jól müködő gazdaságra lenne szükség. Nem valami eredendően mást, hanem többet, jobbat, fejlettebbet, hatékonyabbat célzunk meg. Nem különbségek után kell tehát kutatni, hanem többet ér a magasabb színvonalat eredményező hasonlóságok keresése. 
Napjaink diakóniájának útját négy fázisban lehet összesíteni. Az egyik a személyes fázis, amikor önzetlenül, hitből fakadóan, de szakmailag képzetlen emberek végzik a szolgálatot. A másik a karizmatikus fázis, amikor a diakónusok állandósult társadalmi szükséghelyzetben szervezett összefogással és kellő képzettséggel végzik a diakóniát. A harmadik a professzionális fázis, amikor a diakónusok megértik, hogy szakosodni kell. Fontossá válik a gazdaságosság, a finanszírozás, de ezek mellett hangsúlyt nyer a szakmai teljesítmény és a megfizetettség is. A negyedik a komplex fázis, amikor a diakónia kezelhető számú, de mégis széleskörü igények kielégítésére törekszik. Jelentős befektetéseket eszközöl és valóságos diakónia jellegủ vállalkozások indulnak be. Itt már nem elegendő a tulajdonképpeni értelemben vett diakónusi szakmai tudás, jelentősen felértékelődik a menedzselés kérdésköre.

A diakónia nem szakítható el a gyülekezetektől. Az egyházkerületi, egyházmegyei diakóniai struktúra kiépítése előtt a gyülekezeti diakónia létrehozása kell, hogy az első helyre kerüljön. A gyülekezeteknek úgy kell tekinteni a diakóniára mint az elsődleges feladatok egyikére.

Egy másik cselekvési lehetőség a diakónia minél szerteágazóbb mediatizálása, népszerüsítése, köztudatba való beépítése. Nagy elörelépés lenne a diakónusok önszerveződése. Célja az lenne, hogy a diakónusok találkozzanak, szakmai munkájukat megbeszéljék, újonnan szerzett szaktudományi ismereteiket kicseréljék. A diakónia eme kezdeti fázisaiban, véleményünk szerint a legelső lépés az lenne, hogy a lelkipásztor a diakónust munkatársnak tekintse és a diakónus munkáját, ne teherként fogja fel. Szakemberek hiányában az egyház nem képes egy jól működő szociális hálót kiépíteni.

Az egyház természetéből, küldetéséből és hagyományos tekintélyéből kifolyólag lehetőséget kapott arra, hogy fontos társadalmi gondok kezelését felvállalja. Ehhez azonban az egyházak összefogása szükséges, hogy együttes erővel felvegyék az elszegényedettek terheit. Amennyiben ezt nem teszik meg, az egyház társadalmi szerepe, tekintélye degradálódik. Ezért kötelessége az egyháznak a szegény réteg támogatása úgy lelki, mint anyagi téren.

A hagyományos egyháziasságra jellemző vallásos értékek konzerválódása sokak tudatában még mindig az elmaradottság megbélyegzettségével társul, egy antimodern társadalom képzetével, amely nehezen nyit az új felé. A történelmi egyházaink iránti magas fokú bizalom, nyitottságuk a társadalmi kihívások iránt biztató jelei annak, hogy társadalmunkban a vallásos értékek továbbélése lehetővé tehet egy ki- 
egyensúlyozottabb, értékközpontú fejlődést, mértéktartó arányok fennmaradását tradíció és modernitás között.

\section{Irodalom}

A Királyhágó-melléki Református Egyházkerület Programja. Nagyvárad, 2001.

A Királyhágó-melléki Református Egyházkerület tanintézeteinek évkönyve. Nagyvárad, 1993.

A Vatikáni Zsinat tanitásai. Budapest, 1995.

Az önkormányzatok és a civilszervezetek együttmüködése. Budapest, 1997. Alfaprint nyomda

BECKFORD, James A. (1986)(ed.): New religious movements and rapid social change. Paris, UNESCO és London, Sage.

BENE Éva (1998): Keresztény egyházak nemzeti felelössége. Budapest, Püski Kiadó

BorowiK, Irena - TOMKA Miklós (2002) (eds.): Religion and Social Change in Central and Eastern Europe. Krakow, Nomos.

DARVAS Ágnes (2000): Gyorsjelentés a gyermekszegénységröl Magyarországon és Romániában. Budapest, Szociális Szakmai Szövetség

GÁBOR Kálmán (2000): Társadalmi átalakulás és ifjúság. Szeged, Belvedere.

DR. HÉzSER Gábor (1991): A pásztori pszichológia. Budapest.

DR. TÖKÉs István (1990): A romániai magyar református egyház élete 1944-1989. Budapest.

Egyháztörténet 1, 2. Budapest, 1998. Református Pedagógia Intézet

Egyháztörténet és egyházjog. Nagyvárad, 1996

Erdélyi egyházaink évszázadai. Bukarest, 1992. Transil Kiadó 


\title{
Rákó Erzsébet ${ }^{11}$
}

\section{KÖZIGAZGATÁSI REFORMOK HATÁSA A GYERMEKVÉDELMI ÉS GYÁMÜGYI IGAZGATÁSRA}

\author{
THE EFFECTS OF PUBLIC ADMINISTRATION REFORMS ON \\ CHILD PROTECTION AND GUARDIANSHIP ADMINISTRATION
}

\begin{abstract}
In this paper the author sums up the changes that occurred in the field of child protection administration in the past few years. These modifications were initiated - among others - by the regrouping of the maintenance tasks connected to the social and child protection institutions from the county level administration to the national level and by the general reforms in the public administration. As the districts, the new level of the administration was created the group of authorities, which are approved to implement official measures in the field of child protection transformed. The paper overviews the effects of this transformation process.
\end{abstract}

\section{Bevezetés}

Jelen tanulmányban azokat a közelmúltban történt változásokat tekintjük át, amik a gyermekvédelem igazgatási rendszerét érintették. Ezeket a módosításokat többek között a szociális és gyermekvédelmi intézmények fenntartói feladatainak a megyei önkormányzatoktól az államhoz történő átcsoportosítása és a közigazgatási reformok indukálták. A reformok közül a járások kialakítása érinti lényegesen a témánkat. Magyarországon korábban is, tradicionálisan léteztek járások, ez a rendszer 1983-ban szünt meg. Jelenleg az átalakítás hatására a fővárosban

\footnotetext{
${ }^{11}$ Rákó Erzsébet főiskolai docens, Debreceni Egyetem Gyermeknevelési és Felnőttképzési Kar
} 
23, vidéken 175 járás jött létre. A járások különböző államigazgatási feladatokat látnak el. A járási hivatal szervezeti egységeként müködő ágazati szakigazgatási szervek közé soroljuk többek között a járási gyámhivatalokat, amelyek a gyermekvédelmi és gyámügyi feladatokat oldanak meg. A továbbiakban áttekintjük hogyan változott a gyermekvédelmi, gyámügyi feladatok ellátásának rendszere 2013. január 1-től.

Magyarország Alaptörvénye az alkotmányos jogokról szóló fejezetben megfogalmazza, az állam felelősségét a gyermekek védelmére vonatkozóan. Ennek értelmében minden gyermeknek joga van a megfelelő testi, szellemi és erkölcsi fejlődéséhez szükséges védelemhez és gondoskodáshoz. (Alaptörvény, XVI.)

Az Alaptörvényben foglaltaknak megfelelően a társadalom felelőssége a gyermekekről való gondoskodás. „A gyermekvédelem is közfeladat, ami azt jelenti, hogy a gyermek védelmét szolgáló meghatározott feladatok átkerültek a magánügy köréböl a közügy kategóriájába és biztosításuk a szervezett társadalom feladatává vált. Modern viszonyok között a gyermekvédelemért az államot terheli az elsődleges felelősség, és a további szereplők többnyire az állam által kialakított rendszerhez kapcsolódnak.’(Szöllősi, 2004: 65.)

A családban jelentkező problémák mögött társadalmi okok húzódhatnak meg. „A társadalom szerkezete, müködési mechanizmusa -tehát leglényegibb esszenciája- termeli újra azokat a körülményeket, kegyetlen csapdákat, amelyek kicsúcsosodnak a szülö- gyermek viszony ellehetetlenülésében, csődjében." (Hanák, 1991: 35.)

Fontos kérdés, hogy egy adott társadalomban a kialakult problémákat az egyén felelősségeként vagy társadalmi felelősségként értelmezik-e.

Kerezsi (1996) szerint, ha a kialakuló gondokat társadalmi problémaként határozzuk meg, akkor az azok kialakulásáért megállapítható felelősség nem pusztán az egyéné, a családé, hanem az állam, a társadalom felelőssége is megfogalmazódik. Így szélesebb hatósugarú segítő rendszer kialakítására van mód.

A szerzőkkel egyetértünk abban, hogy a gyermekvédelmi problémák többsége makrotársadalmi okokra vezethető vissza. A problémák típusa, gyakorisága, a társadalom fejlődésével együtt változik. A problémák megoldására irányuló társadalmi válaszok jelentős mértékében függenek attól, hogy az adott társadalom miként viszonyul a gyermekekhez, közfeladatként hogyan valósul meg a gyermekek védelme.

Az Országgyülés feladata annak eldöntése, hogy hogyan határozza meg a közfeladatok fogalmát. A közfeladatok ellátásában a közigazga- 
tás intézményrendszerén belül, a civil közigazgatás részeként szerepet kapnak a helyi önkormányzatok.

A Magyarországi Önkormányzatokról szóló törvény a helyi közügyek, valamint a helyben biztosítható közfeladatok körében ellátandó helyi önkormányzati feladatok közé sorolja a szociális, gyermekjóléti szolgáltatások és ellátások biztosítását. (13.par.)

Ezen szolgáltatások biztosítására vonatkozóan a Gyermekvédelmi törvény ad részletes iránymutatást. A települési önkormányzat, fővárosban a fóvárosi kerületi önkormányzat feladata a gyermekek védelme helyi ellátó rendszerének kiépítése és müködtetése, a területén lakó gyermekek ellátásának megszervezése. Az 1. számú táblázatban foglaltuk öszsze a települési önkormányzatok gyermekvédelmi feladatait.

A pénzbeli ellátások közül a rendkívüli gyermekvédelmi támogatást biztosítja a helyi önkormányzat.

A személyes gondoskodást nyújtó gyermekjóléti alapellátások közül a települési önkormányzat lakosságszámtól függetlenül köteles gyermekjóléti szolgálatot müködtetni.

A gyermekek napközbeni ellátását és átmeneti gondozását a lakosság lélekszámának tükrében kell biztosítania a települési önkormányzatnak:

- Ahol tízezernél több állandó lakos él bölcsődét,

- Ahol húszezernél több állandó lakos él, a bölcsőde mellett gyermekek átmeneti otthonát,

- Ahol harmincezernél több állandó lakos él, a bölcsőde, a gyermekek átmeneti otthona mellett családok átmeneti otthonát,

- Ahol negyvenezernél több állandó lakos él, a bölcsőde, a gyermekek és a családok átmeneti otthona mellett gyermekjóléti központot köteles müködtetni.

A megyei jogú városok a lakosságszámtól függetlenül kötelesek gyermekjóléti központot múködtetni.

Az intézmények ellátási területe a település valamennyi lakosára kiterjed.

A települési önkormányzat a személyes gondoskodást nyújtó gyermekjóléti alapellátásokat más szervvel, személlyel kötött ellátási szerződés útján, illetve társulásban is biztosíthatja tekintettel arra, hogy az intézmény és az ellátottak lakóhelye közötti távolság lehetőleg ne haladja meg az ötven km-t. 
A gyermekjóléti intézmények müködtethetők többcélú intézményként, amennyiben ehhez a személyi tárgyi feltételek külön-külön adottak. Továbbá közös igazgatású intézményként is müködhetnek, de ebben az esetben a gyermekjóléti intézmények önálló intézményegységként kell, hogy funkcionáljanak.

A települési önkormányzat a gyermekjóléti és gyermekvédelmi feladatainak ellátásáról minden év május 31-ig - a külön jogszabályban meghatározott tartalommal - átfogó értékelést készít. Az értékelést települési önkormányzat esetén a képviselö-testület általi megtárgyalást követően - meg kell küldeni a gyámhatóságnak. A gyámhatóság az értékelés kézhezvételétől számított harminc napon belül javaslattal élhet a települési önkormányzat, illetve az állam fenntartói feladatainak ellátására a Kormány rendeletében kijelölt szerv felé, amely hatvan napon belül érdemben megvizsgálja a gyámhatóság javaslatait és állásfoglalásáról, intézkedéséről tájékoztatja.

A települési önkormányzatok a törvényben meghatározott személyes gondoskodást nyújtó ellátásokat állami, egyházi és egyéb nem állami fenntartóval kötött ellátási szerződés útján is biztosíthatják. Fontos változás, hogy amennyiben az ellátási szerződés alapján a feladat ellátásában vallási vagy világnézeti elkötelezettségü nem állami szerv müködik közre, a megállapodás megkötése nem mentesíti a települési önkormányzatot, valamint az állami szervet a feladat ellátási kötelezettség alól azon gyermek tekintetében, akinek szülője nem kívánja a nem állami szerv szolgáltatását igénybe venni.

Az ellátási szerződés tartalmazza többek között azt az időszakot, amelyre a szerződést kötötték, amely időszak a bentlakásos gyermekintézmény esetén nem lehet kevesebb 5 évnél, valamint a szolgáltatást végző nem állami szerv nyilatkozatát a nyilvántartási kötelezettség, az adatkezelés és az adatvédelem szabályainak ismeretére és betartására.

A gyámhatóság feladat- és hatáskörét 2013. január1-től a települési önkormányzat jegyzője, a járási (fővárosi kerületi) gyámhivatal, valamint a szociális és gyámhivatal gyakorolja.

A járási gyámhivatalok létrejöttével módosultak a jegyző korábbi feladatai is. Így például a védelembe vétel, mint hatósági intézkedés átkerült a jegyzőtől a járási gyámhivatalok kompetenciái közé. Az 1. számú táblázatban foglaltuk össze a jegyző és a járási gyámhivatalok föbb tevékenységeit.

A Szociális és Gyámhivatalok a kormányhivatal szakigazgatási szerveként számos feladatot látnak el többek között szakmai irányítási, 
ellenőrzési, értékelési feladatokat. Részletesen bemutattuk az 1. számú táblázatban.

Jelentős feladatátcsoportosítással is járó változást hozott szintén 2013. január 1-től a gyermekvédelem területén a Szociális és Gyermekvédelmi Főigazgatóság, mint központi hivatal létrehozása. A változást többek között a megyei önkormányzatok konszolidációja, a szociális és gyermekvédelmi intézmények állam által történő átvétele generálta.

A Főigazgatóság központi szervböl, valamint valamennyi megyében müködő megyei és fővárosi kirendeltségekből áll. Az intézmény elsősorban fenntartói és módszertani feladatokat lát el. Lényeges változás, hogy a korábban a Nemzeti Család- és Szociálpolitikai Intézethez tartozó országos gyermekvédelmi szakértői bizottságot is a Főigazgatóság működteti 2013. januártól. Továbbá a Főigazgatóság Központi szervének fenntartásában müködik valamennyi javítóintézet, speciális gyermekotthon. További feladatok részletesen az 1. számú táblázatban találhatók.

\section{1. táblázat A gyermekvédelmi rendszer müködtetői és feladatuk 1997 után}

Önkormányzati

E 11 á t á s o k
Állami feladatok

feladatok

G y á m h a tós ági in tézke -

d é s e k

\begin{tabular}{|c|c|}
\hline Települési önkormányzat & Jegyző \\
\hline $\begin{array}{l}\text { Biztosítja: a gyermekjóléti alapellátá- } \\
\text { sokat } \\
\text { - rendszeres gyermekvédelmi kedvez- } \\
\text { mény } \\
\text { - rendkívüli gyermekvédelmi támoga- } \\
\text { tás } \\
\text { - gyermekjóléti szolgáltatás } \\
\text { - gyermekek napközbeni ellátása (böl- } \\
\text { csőde, családi napközi, házi gyer- } \\
\text { mekfelügyelet) } \\
\text { - gyermekek átmeneti gondozása (át- } \\
\text { meneti otthon) }\end{array}$ & $\begin{array}{l}\text { Hatásköre különösen: } \\
\text { - gyámhatósági ügyekben megkeresés- } \\
\text { re környezettanulmányt készít, } \\
\text { - megállapítja a kiegészító gyermekvé- } \\
\text { delmi támogatásra való jogosultságot } \\
\text { - megállapítja az óvodáztatási támoga- } \\
\text { tásra való jogosultságot }\end{array}$ \\
\hline $\begin{array}{l}\text { Szervezi és közvetiti a máshol igénybe } \\
\text { vehetö ellátáshoz való hozzájutást }\end{array}$ & \\
\hline
\end{tabular}




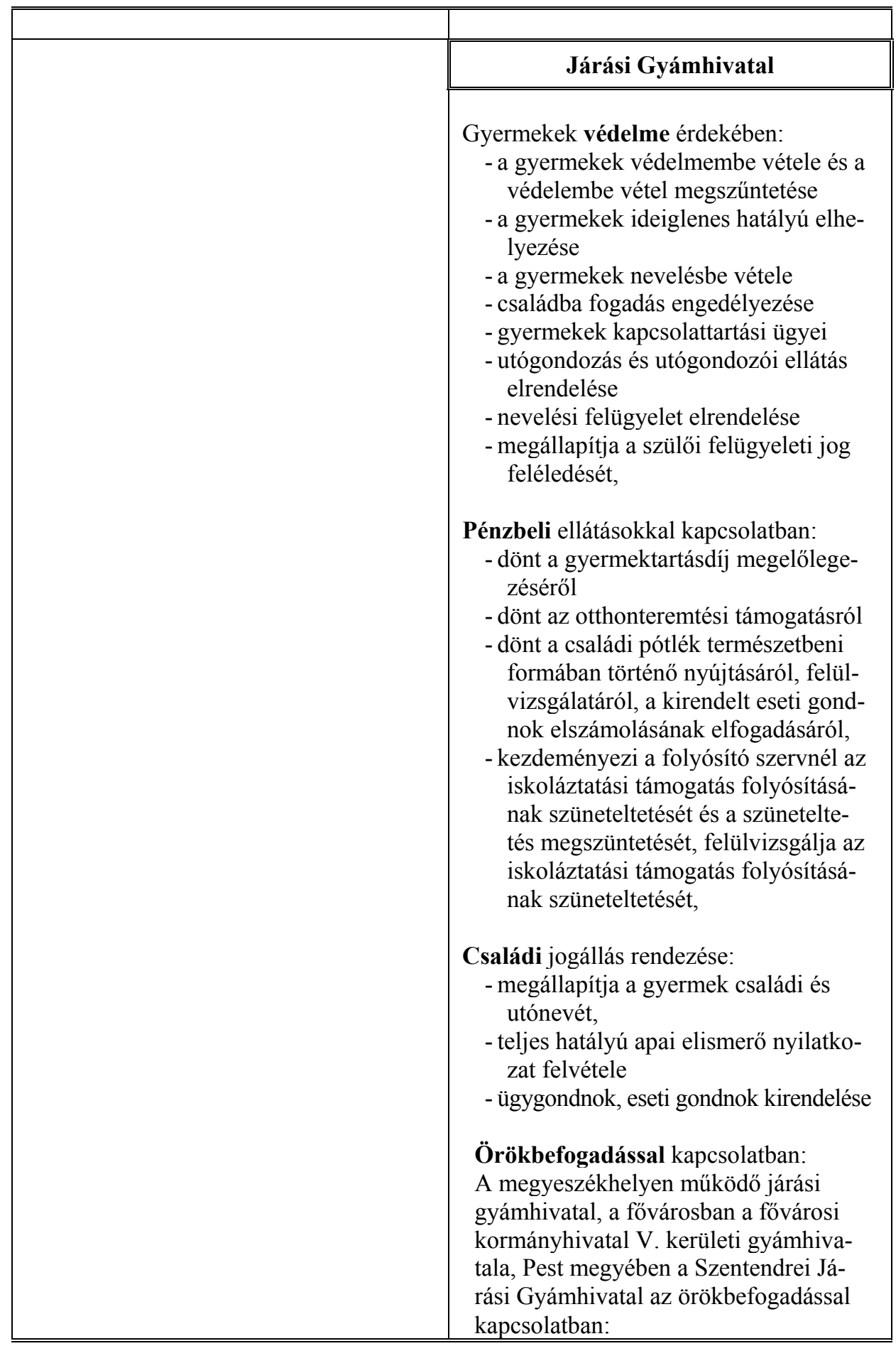


a) dönt a gyermek örökbe fogadhatónak nyilvánításáról,

b) felveszi, elbírálja és jóváhagyja a szülönek azon jognyilatkozatát, amelyben hozzájárul gyermeke ismeretlen személy általi örökbefogadásához

- dönt az örökbefogadás engedélyezéséröl,

- dönt a felek közös kérelme alapján az örökbefogadás felbontásáról,

- pert indíthat, illetve kezdeményezhet a gyermek örökbefogadásának felbontása iránt,

- kérelemre felvilágosítást adhat a vér szerinti szülő adatairól.

\section{Pert indíthat:}

- gyermek elhelyezése, illetve kiadása,

- a gyermeket megillető tartási követelés érvényesítése,

- a szülői felügyelet megszüntetése vagy visszaállítása érdekében,

Gyámság, gondnokság:

- a gyermek részére gyámot, családbafogadó gyámot, hivatásos gyámot rendel,

- ideiglenes gondnokot, gondnokot, hivatásos gondnokot rendel,

- irányítja és felügyeli a gyám, a hivatásos gyám tevékenységét,

- felfüggeszti, elmozdítja vagy felmenti a gyámot, a gondnokot,

- meghatározott esetekben zárlatot rendel el, zárgondnokot, eseti gondnokot, ügygondnokot, az ügyei vitelében akadályozott személy képviseletére és méhmagzat részére gondnokot rend

- vagyoni ügyek

- kiskorú házasságkötésének engedélyezése

- feljelentés (kiskorú veszélyeztetése, tartás elmulasztása, stb.)

- eljár a tartásdíj külföldön való behajtása tárgyában

- közremúködik a gyermektartásdíj iránti igény érvényesítésében a nemzetközi szerződésben meghatá- 


\begin{tabular}{|c|c|}
\hline & $\begin{array}{l}\text { rozottak szerint, } \\
\text { - közremüködik a gondozási díj, va- } \\
\text { lamint a megelőlegezett gyermek- } \\
\text { tartásdíj behajtásában } \\
\text { - a cselekvőképességet érintő gondnok- } \\
\text { ság alá helyezés, annak megszünteté- } \\
\text { se és felülvizsgálata, valamint ezzel } \\
\text { összefüggésben a választójogból való } \\
\text { kizárás és a kizárás megszüntetése }\end{array}$ \\
\hline $\begin{array}{c}\text { Szociális és Gyermekvédelmi Főigaz- } \\
\text { gatóság }\end{array}$ & Szociális és gyámhivatal \\
\hline $\begin{array}{l}\text { - szociális és gyermekvédelmi intéz- } \\
\text { mények fenntartói feladatait látja el } \\
\text { - megállapítja az intézményi térítési } \\
\text { díjat, (a föigazgató egyetértési jo- } \\
\text { got gyakorol az intézményi térítési } \\
\text { díj összegének meghatározásához.) } \\
\text { - eljár a müködési engedélyezéssel } \\
\text { kapcsolatos ügyekben, } \\
\text { - szervezi, irányítja és ellenőrzi a } \\
\text { fenntartott intézmények szakmai } \\
\text { feladatainak végrehajtásához szük- } \\
\text { séges pénzügyi feltételeket, } \\
\text { - összegyüjti, ellenőrzi a fenntartott } \\
\text { intézmények gazdálkodására vo- } \\
\text { natkozó kötelezö, rendszeres és ad } \\
\text { hoc jellegü adatszolgáltatásokat, } \\
\text { szükség szerint összesítve továbbít- } \\
\text { ja azokat a Főigazgatóság központi } \\
\text { szervéhez és a miniszter által veze- } \\
\text { tett minisztériumba, } \\
\text { A Főigazgatóság ellátja az országos } \\
\text { szociális, illetve gyermekjóléti, gyer- } \\
\text { mekvédelmi módszertani feladato- } \\
\text { kat. Ennek keretében: } \\
\text { a) összesíti, kiértékeli és elemzi a } \\
\text { szolgáltatók és intézmények által szol- } \\
\text { gáltatott és más, az ellátórendszerrel } \\
\text { kapcsolatos adatokat, javaslatokat, } \\
\text { azokat megküldi a miniszternek és a } \\
\text { honlapján folyamatosan közzéteszi, } \\
\text { b) javaslatot tesz az országos ellátó- } \\
\text { rendszer fejlesztésére, részt vesz az } \\
\text { ellátórendszer fejlesztéséhez szüksé- } \\
\text { ges források tervezésében, }\end{array}$ & $\begin{array}{l}\text { Hatásköre különösen: } \\
\text { - ellátja az illetékességi területéhez tar- } \\
\text { tozó települési önkormányzat jegyzö- } \\
\text { jének és a járási gyámhivatalnak a } \\
\text { szakmai irányítását, felügyeletét és } \\
\text { ellenőrzését, } \\
\text { - másodfokú hatósági jogkört gyakorol } \\
\text { a települési önkormányzat jegyzöjé- } \\
\text { nek, a járási gyámhivatalnak a gyer- } \\
\text { mekvédelmi és gyámügyi hatósági } \\
\text { ügyeiben, } \\
\text { - a gyermekvédelmi jelzőrendszer } \\
\text { elégtelen müködése esetén megteszi } \\
\text { a szükséges intézkedést } \\
\text { - gyermekjóléti és gyermekvédelmi } \\
\text { intézmények müködésének engedé- } \\
\text { lyezése és tevékenységük ellenőrzése } \\
\text { - elösegíti és koordinálja a bünelkö- } \\
\text { vetés, illetve a bünismétlés megelö- } \\
\text { zését célzó programok indítását a } \\
\text { veszélyeztetett, továbbá a büncse- } \\
\text { lekményt elkövetett, de nem bün- } \\
\text { tethető, valamint a büntetöeljárás } \\
\text { alá vont gyermekek számára. } \\
\text { - gyermek- és ifjúságvédelem koordi- } \\
\text { nátori feladatai } \\
\text { A szociális és gyámhivatal ellenőrzési } \\
\text { jogkörében legalább négyévenként el- } \\
\text { lenörzi: } \\
\text { - a gyámhatóságok gyámügyi és } \\
\text { gyermekvédelmi hatósági tevékeny- } \\
\text { ségének jogszerüségét, } \\
\text { az egészségügyi szakfelügyelet ki- } \\
\text { vételével a Szociális és Gyermek- }\end{array}$ \\
\hline
\end{tabular}


c) módszertani útmutatókkal, ajánlásokkal és egyéb kiadványokkal segíti a szolgáltatók és intézmények szakmai feladatainak teljesítését, az aktív szociálpolitikai eszközök alkalmazását,

d) új szolgáltatási formák és szakmai módszerek bevezetése érdekében modellkísérleteket szervez,

e) részt vesz a minőségfejlesztési stratégia, a standardok, a szolgáltatási protokollok, valamint a szakmai ellenőrzés módszertanának és eljárásrendjének kidolgozásában,

f) figyelemmel kíséri az ellátórendszert érintő tudományos kutatómunka eredményeit, elősegíti azok elterjesztését és gyakorlati alkalmazását,

g) kutatásokat folytat, illetve szervez,

h) ellátja az alapító okiratában meghatározott egyéb feladatokat.

Módszertani feladatainak ellátásába szociális, gyermekjóléti, gyermekvédelmi szolgáltatókat, intézményeket, illetve szakmai szervezeteket is bevonhat.

\section{- A Főigazgatóság müködteti az} országos gyermekvédelmi szakértői bizottságot.

- közvetlen intézmények fenntartása (javítóintézetek, speciális gyermekotthonok) védelmi Főigazga-tóság, illetve az Országos Gyermekvédelmi Szakértői Névjegyzékbe felvett szakértő szükség szerinti bevonásával - a külön jogszabályban meghatározottak szerint - a gyermekjóléti és gyermek-védelmi szolgáltatók tevékeny-ségét.

- a Szociális és Gyermekvédelmi Főigazgatóság bevonásával véleményezi a helyi önkormányzatnak az önkormányzati ellátórendszer átalakítására vonatkozó javaslatait, és szükség esetén kezdeményezi a javaslatok megváltoztatását.

\section{Emberi Erőforrások Minisztériuma}

- ágazati irányítás és szakmai felügyelet

- Család- és Gyermekvédelmi Szakmai Kollégium

- Központi Hatósági Feladatok

- Országos Örökbefogadási Nyilvántartás

- (Gyermekvédelmi és Gyámügyi Főosztály)

\section{Nemzeti Család- és Szociálpolitikai Intézet}

Az Emberi Erőforrások Minisztériumának családpolitika, szociálpolitika, gyermekvédelem, ifjúságpolitika, esélyegyenlőség és drogmegelőzés ágazati irányítását segítő és támogató háttérintézménye. Feladatuk kiterjed a tudományos kutatás, módszertani fejlesztés és szolgáltatás, valamint statisztikai és információs szolgáltatások körére. Ezen feladatokat érintő fejlesztési programok elökészítését és lebonyolítását végzi. 
A járások kialakítása jelentős hatással volt a gyermekvédelmi és gyámügyi igazgatásra is. Amennyiben az új szervezeti rendben hatékonyabbá válik az állampolgárok ügyeinek intézése, úgy vélhetően a gyermekvédelmi, gyámügyi feladatok megoldása is hatékonyabb lehet. Ebben az esetben ugyan közvetetten, de megvalósul a gyermekek „mindenek felett álló érdekének” a képviselete.

\section{Irodalom}

HANÁK Katalin (1991): Állami gondozott csecsemők Pest megyében. Esély, 3. 4. sz. 12-39.

KEREZSI Klára (1996): Gyermek, család, társadalom. In Szilvási Léna (szerk.): Gyermek-Család-Társadalom. Budapest, Hilscher Rezsö Szociálpolitikai Egyesület

SzÖLLŐSI Gábor (szerk.) (2004): Gyermekjóléti alapellátás. Budapest, Nemzeti Család- és Szociálpolitikai Intézet

\section{Felhasznált jogszabályok}

Magyarország Alaptörvénye

2011. évi CLXXXIX. Törvény Magyarország helyi önkormányzatairól

331/2006. (XII. 23.) Korm. Rendelet a gyermekvédelmi és gyámügyi feladat- és hatáskörök ellátásáról, valamint a gyámhatóság szervezetéről és illetékességéről

316/2012. (XI. 13.) Korm. Rendelet a Szociális és Gyermekvédelmi Főigazgatóságról

218/2012. (VIII. 13.) Korm. Rendelet a járási (fővárosi kerületi) hivatalokról 
Szociálpedagógia - ismeretek 



\title{
Láczay Magdolna ${ }^{12}$
}

\section{A TEHETSÉGGONDOZÁS MEGJELENÉSE A MODERN MAGYAR OKTATÁSPOLITIKÁBAN - A LAPPANGÓ TEHETSÉGEK ESÉLYTEREMTÉSÉRŐL}

\author{
THE TALENT ON MODERN HUNGARIAN EDUCATION POLICY \\ THE LATENT TALENT OF CREATING OPPORTUNITIES
}

\begin{abstract}
This lecture was written for a conference about the educational innovation of social affairs specialists along with the presentation of the current status and practice of the education. "Nurturing talents" is often heard about in tenders and pedagogical programs but it has different meanings in each different context. This paper is not about the exceptional talents, the professional and cultural elite but those with latent, hidden talents and missing environmental factors of the Mönks-Renzulli model. In the Northern Plains and on the both sides of the Hungarian/Romanian border there are many of these kind of talented children. Their fate depends on how the educational policy can develop and carry out a schooling model that provides an effective substitute for nurturing family environment and a competitive peer community yet helping them to keep their identity. This paper is to find hungarian and international examples and traditions for this.
\end{abstract}

\section{Bevezetés}

Az előadásomat arra a konferenciára szántam, amely a szociális területen dolgozó szakemberek oktatásának az innovációjára, a meglévő képzések és a gyakorlat bemutatására vállalkozott. A tehetséggondozás fogalma egyre gyakrabban hallható különböző pályázatok, pedagógiai

\footnotetext{
12 Prof. h.c. dr. habil Láczay Magdolna, dékánhelyettes, tanszékvezető főiskolai tanár, Debreceni Egyetem Gyermeknevelési és Felnőttképzési Kar
} 
programok kapcsán, de szinte minden szövegkörnyezetben más jelentéstartalommal ruházzák fel. Én nem az átlag feletti képességekkel megáldottakról, a szakmai és/vagy a kulturális elit képzéséről, hanem a lappangó tehetségek esélyteremtéséről kívánok szólni, akiknél a Mönks-Renzulli modell feltételrendszeréből a környezeti tényezők sérülnek, vagy akár hiányoznak is. Az északalföldi térségben a magyar és a román határ két oldalán sok a hasonló sorsú halmozottan hátrányos helyzetü gyermek. Az ő sorsuk függ attól, hogy képes lesz-e az oktatáspolitika olyan iskolamodell megvalósítására, amely pótolni, segíteni lesz képes a családi háttér és az ösztönző környezet, a motivált iskolatársak hiányát, úgy, hogy mindeközben képes lesz megőrizni identitásukat, megteremteni integrációjukat. Ehhez keresek nemzetközi példákat és hazai hagyományokat.

\section{A válságok lefelé húzó spirálján kellene megállni...}

Az előadásom témaválasztását befolyásolta a konferencia tematikája, és meghatározta, hogy miképpen szeretném rendezni a gondolataimat a tehetséggondozásról.

A tehetséggondozás fogalma egyre gyakrabban hallható különböző pályázatok, pedagógiai programok kapcsán, mégis az az ember érzése, hogy szinte minden szövegkörnyezetben más jelentéstartalommal ruházzák fel. Az emberi tudás kibontakozásának a támogatását, mint gazdasági tényezőt, a menedzsment tudományok klasszikus müveinek a szerzőihez hasonlóan, úgy egy évszázadra datálják, míg az egyéni kiváló tehetségek életútjáról már az ókorból vannak ismereteink. A kiválasztottak nevelése pedig - noha ez nem feltétlenül és nem mindig kapcsolódott tehetséghez - a dinasztiák trónörökösei nevelésének a krónikáiban, a nagy tradícióval rendelkező iskolák történetének lapjain kiemelten vannak jelen. Ez a többféle megközelítés valószínủ a tehetséggondozás, a tehetségfejlesztés többirányú értelmezéséből adódik. Érthetjük a már felismert tehetségek kiteljesedését támogató oktató-nevelő környezetre, annak alakítására, intézményrendszerére, de ugyanilyen fontos a még fel nem fedezett, a környezeti tényezők által rejtve maradó, lappangó tehetségek felkutatására, a számukra kibontakoztatást jelentő esélyteremtés munkájára is. Az első értelmezés társadalmi hatása a szakmai és kulturális elit képzését éppúgy támogathatja, mint egyegy kiemelkedő tehetség útjának az egyengetését. A második értelme- 
zésben, minden gyermekre kiterjesztve, olyan intézményes szocializáció segítését feltételezzük, amely elősegíti azoknak a készségeknek a fejlesztését, amelyekkel potenciálisan nagyobb teljesítményekre lesznek képesek, jobban beilleszkednek a környezetükbe, erőteljesebben fejlődik személyiségük. A két értelmezés, két vagy annál is több pedagógiai, szakmai kihívást, utat, módszert hozott már létre.

A szociális oktatásnak, ami elsősorban a második értelmezési kört érinti - a fogalmat a fenti értelmezés alternatív megfogalmazásaként használva -, és ennek az innovációjának, sajátos történelmi keretet ad az az uniós pályázati lehetőség, amelynek kapcsán hosszú évtizedek után találkozhatnak az északkeleti régióban a határ két oldalán élök, akiknek azonosak ugyan a történelmi, a kulturális gyökerei, de az elmúlt évtizedek elzártságában sajátos problémáik és válaszaik is voltak. Mielőtt a tehetséggondozásról ilyen összefüggésben szólnék, a téma aktualitását is szeretném kiemelni. A szociális érzékenység, a problémák észlelése és megértése iránti igény a mi térségünkben a határ mindkét oldalán sok azonosságot mutat. Új szakemberek kellenek, akik tudnak az azonos kultúrára támaszkodva hivatástudattal fordulni a most felnövő generációhoz, hogy elősegítsék a lehetséges kibontakoztatásukat. A problémák megértése, feltárása, a segítés lehetőségének és a segítőknek a támogatása nemcsak egyéni hivatás, misszió, hanem társadalmi igény és kötelezettség is. Az oktatás megújítására ezért is szükség van. Másfelöl, nemcsak generációváltás történt többször Trianon óta, hanem az életmód változott, egyes esetekben a lakosság is cserélödött. A lehetőségek és az eredmények ellenére, a szegénység, a halmozottan hátrányos helyzetü rétegek térben és nagyságrendben növekvő száma miatt úgy érzem, hogy a pedagógusnak azt a csodát kellene megvalósítania, ami elméletben ugyan elképzelhető, de majdnem annyi fantázia kell hozzá, mint a mesés Münchausen báró kalandjaihoz. Az egymásra torlódó válságok lefelé húzó spirálján kellene megállni, és visszafordulva, mintegy szerpentinen visszakapaszkodni. A szociálpszichológia megteremtői (Riesman 1996, Aronson, 1987) a második világháború után, amerikai környezetben, felismerik, és leírnak ehhez hasonló jelenséget. Tudniillik, hogy milyen nagy jelentősége van a tradíciónak, az identitásnak, az előítéletnek egy közösség életmódjában, és milyen módon befolyásol(hat)ják ezek a közösséget. Én ennél most konkrétabb kérdésekre keresem a válaszokat. Olyanokra, hogy mi a tehetség, hogyan ismerhető fel, hogyan kell kibontakoztatni, fejleszteni itt és most? Esetleg hol lehetne jó példákat látni? 


\section{A Mönks-Renzulli modell nekünk szóló üzenete}

A tehetség fogalmának koronként és kultúránként eltérő értelmezései léteznek, amire gyakran azt mondják: született tehetség, kiválasztott, zseni vagy őrült, mások az eredményesek, a sikeresek, a kiválók csoportját elitnek titulálják, elitnevelésre vállalkoznak stb. Balogh László, egyetemünk professzora a Nemzeti Tehetségsegítő Tanács számára készített tanulmányában (Balogh, 2007) a tehetség fogalmát már a két pszichológus elméletének összekapcsolásában vizsgálja. Renzulli 1978ban közzétett úgynevezett háromkörös modelljében (Renzulli, 1978) három tulajdonságcsoport alapján, azok közös mezőjében jelölte ki a tehetség fogalmát. A szükséges három tulajdoncsoportot:

- átlag feletti képességek, amelyeken belül később még két csoportot alkotott, az átlag feletti képességek mellett az átlagot meghaladó speciális képességeket is ide sorolva

- a feladatkötelezettség, másképpen a motiváció

- valamint a kreativitással rendelkezés együttes jelenlétét, egymásra hatását, integrációját nevezte a tehetség kritériumainak.

Az egyéni tulajdonságok meglétét és kibontakozását vizsgálva Mönks a környezeti tényezőkre hívta fel a figyelmet (Mönks, 1992). A háromkörös modellt egy egyenlőszárú háromszögbe téve megnevezte azt a tehetséggondozásért felelős környezetet, amelyben a család, az iskola és a társak együttesen hatnak.

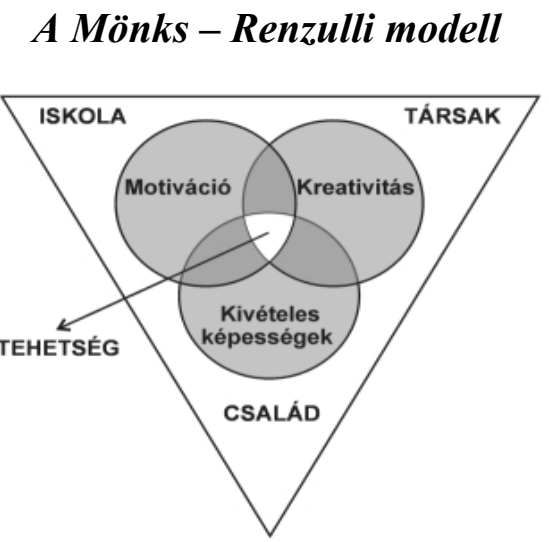

A szociológia más müvelői ugyanezen környezeti elemeket más néven vagy összefüggésben tőkefajtának tartják, amiben a kapcsolati rend- 
szert, az iskolai kötődést vagy a kulturális szintet egymásra átválthatóként azonos módon emlegetik a gazdasági vagy a politikai érvényesüléshez szükséges tőkével (pl. Bordieu, 1978). Maradjunk a kiindulási stádiumban, mert nem a szükséges, hanem az elégséges vagy a hiányzó környezeti tényezőkkel kell szembenéznünk, amikor a tehetséggondozás feltételeként az esélyteremtés körülményeit akarjuk kialakítani. Ma az északkeleti és északalföldi térségekben szinte ugyanazon nehéz gazdasági környezet van, nevezetesen a családok súlyos szociális helyzetben vannak, a család szerkezete nagyon vegyes képet mutat, és így az iskolára lényegesen nagyobb felelősség hárul. Gyakran nemcsak a gyermekek, hanem a családjuk gondjával is szembe kerülnek a pedagógusok. Ezzel együtt gyakran felvetődnek etnikai kérdések, amelyben kiemelt, és a határ mindkét oldalán, nagy kihívást jelent a roma származású, legtöbbször eltérő kulturális szinten lévő gyermekek integrációja.

A probléma kezelésére évekig ajánlott stratégiaként a felzárkóztatás gondolatát hangoztatták. Ám logikailag is belátható, hogy a felzárkóztatás sikere csak kis különbségek esetében képzelhető el. Ott, ahol egy teljesen más életvitelből, hagyományok és szokások elhagyásával, kellene új kultúrára váltaniuk, akár egy generáción belül, ott nem vagy csak látszateredmények születhetnek. Az iskola nem tudja megoldani sem a munkanélküliséget, sem a családi problémákat, nem tudja megkerülni a kettős neveltetésből, a szülők eltérő attitüdjéből eredeztető konfliktusokat, de modellt adhat, vagy jó példákat mutathat fel.

A lappangó tehetségek esélyteremtése, tehetséggondozása éppen a fentiekböl fakadóan olyan ismereteket feltételez, amelyet nem a pedagógusnak kellene elsősorban kutatnia, bemutatnia, hanem egy több területet vizsgáló komplex kutatás eredményeiként kellene az ismeretekhez jutniuk. E kutatás részeként, és olykor helyettesítőjeként az oktatásra, az iskolára hárul a feladat, amit nem csak a didaktika eszközeivel, hanem ennél jóval szélesebb módszertani felkészültséggel tárhatna fel a pedagógus társadalom, és ezáltal lenne képes kezelni a saját környezetében adódó problémákat. Amennyiben ezt a mai magyar pedagógus társadalom meg tudja oldani, ezt nevezhetjük egy rendkívül fontos innovatív megoldásnak. A legfontosabb, a témánkat érintő társadalmi problémákat e téren a következőkben tudnám összefoglalni.

- A család és az iskola változó szerepét sok tényező együttesen idézte elö, és a változás irányát is ugyanilyen sokszínủen kellene megközelíteni. Az iskolának nemcsak a gyermekeket, hanem a hozzájuk tartozó felnőtteket is oktatnia kellene, de legalábbis az 
életmódprogramok népszerüsítését nagyobb számú pedagógus és szociális munkatárs innovatív együttmüködésével lehetne elindítani.

- A hátrányos, sok esetben halmozottan hátrányos térségekben élő gyermekek közül előfordulhat, hogy - egy tehetségkutató verseny során - valakit véletlenül sikerül megtalálni, az ilyen térségekben azonban az esélyteremtés a legnagyobb kihívás. Legtöbbször új szemléletü iskolatípusokban, osztályokban lehetne gondolkodni, sőt kisebb csoportokban, esetleg egyes tanulók szintjén differenciált pedagógiai módszerek kombinációja válik szükséges.

- A periférián egyre szükül az ösztönzést segítő példák száma, az iskolában a tehetséges gyermeknek nincsenek olyan társai, akik újabb eredmények elérésére ösztönöznék. Ennek oka mára elsősorban nem, vagy nem a korábbi értelmezésben megfogalmazott etnikai szegregáció, hanem a települések leszakadása, az elszegényedett környezet, a módosabb, motiváltabb gyermekek hiánya.

- Az egyéni pedagógiai módszerek, a mindenkit a saját előbbre haladási ritmusa szerint támogatni képes iskola, legtöbbször a szegregáció-integráció vitájába keveredik, miközben a differenciált nevelés, a kulturális identitás megőrzése csak egyik vagy másik etnikum gyermekei számára elfogadott.

- Megjegyzendö, hogy vannak olyan települések, ahol nem értelmezhető a szegregáció, mivel a gyermekek 80-90 százaléka halmozottan hátrányos helyzetü, de a maradék néhány százalék sem él sokkal jobban. Ugyanez az arány esetenként az etnikai összetételben megfordult, és a korábban szegregáltnak mondott roma lakosság között van 10-20 százalék nem roma gyerek.

A társadalmi problémák nem könnyen tehetők át a pedagógiai vitákba, és nem is kellene. A jelenségek okait nem az iskolának kell feltárnia, az oktatásnak nem a miérteket, hanem a hogyanokat kellene kidolgoznia, hogy a leszakadókat ne veszítsék el, hogy esélyt teremtsenek az öngondoskodás, a társadalmi integráció elérésére. Gondolok itt arra, hogy vajon van-e esélyegyenlösége a szülői háttérrel nem rendelkező vagy támogatást valamilyen okból nem kapó gyermeknek? Kik és hogyan tudják a hiányzó környezeti feltételeket pótolni? Különösen vonatkozik ez az állami gondozottakra, a szüleiktől külön élökre vagy a veszélyeztetett gyermekekre, akiknek ez az esély legtöbbször az iskolában sem érhető el. Fokozottabbnak érezhetjük a veszélyt azon településeken 
élők esetében, ahol megszüntették a helyi iskolát. Az összevont, több települést ellátó, pedagógus hiánnyal küzdő iskolákban pedig esély sincs arra, hogy a nevelő a családig eljusson, hiszen gyakran a szülőkkel nem is találkoznak! Ezekröl még pontos adatok, fontos egyeztetések, viták kellenek, és a még fontosabb feltételrendszer kialakítása szükséges. A fenti dilemmák megoldására törekedve érdemes azonban szétnézni a világban, ki hogyan próbálkozott, mikor kezdett hasonlókkal foglalkozni, és milyen eredményt ért el.

\section{A modern oktatási rendszerek kialakulása}

A tehetség gondozásának múltja évezredesnek mondható, a mi esetünkben szinte a honfoglalástól, az államalapítástól nyomon követhető, igaz elsősorban a kiválasztottak számára müködtették. I. István királyunkat apja a nyugati kereszténység ismeretére nevelteti. Később ö az, aki behívja a szerzeteseket, és Gellért püspökkel oktattatja fiát, annak jó királlyá nevelése érdekében. Ettől kezdve Könyves Kálmán, III. és IV. Béla udvarában vagy az Anjou királyok központjaiban, és különösen Mátyás uralkodásakor a tudós papok mellett az írásbeliség az állam legnagyobb hatalmaságait segíti, és mellette a történetírók, a költők eszközévé kezdett válni. Így az írásbeliség elterjedése fokozatosan terjedt át az egyházi kiváltságosok bevonásával az államigazgatásra, majd az írástudó hivatalnokok, iskolák révén egyre nő a kiválasztottak száma. Hajnal István munkásságából (Hajnal, 1933) megismerhetjük, hogy miképpen válhatott az írás szakrális kiváltságból szakszerüséggé, hivatalalakító tényezővé, majd polgári szükségletek kielégítésévé, társadalmi igénnyé. A magyar történelmi hagyomány szerint a királyaink, vezetőink karizmatikus voltát elsősorban tudásuk, bölcsességük, igazságosságuk erősítette meg. Valami hasonló okból alakulhattak ki azok a szólások, közmondások, amelyek a tanulás jelentőségét, fontosságát hivatottak igazolni a fiatalok szemében. (Amit egyszer megtanulsz, azt senki nem veheti el, Amit Jancsika megtanul, János sem felejti el, Ahány nyelv, annyi ember, A tudás hatalom, stb.)

Mindeközben a kolostorokban lévő iskolák mellett, a legerősebb felekezetek támogatásával, kollégiumok alakulnak, ahol olyanok is tanulhattak, akik világi szolgálatra, hivatalra készültek. Ide bekerülhettek szegényebb családok gyermekei, de csak akkor, ha a szülők nemesi származásúak. Másokra alig van példa, legfeljebb, ha valaki igen jeles 
tulajdonságokat mutatott, akkor az uralkodó kegyéből nemességet kaphatott, vagy a foglalkozásából adódóan vált kiváltságossá (honoráciorok, azaz értelmiségi foglalkozást üzők). Az idők folyamán azonban a városi polgároknak, akiknek többsége valamilyen mesterséget tanult, külföldi vándorúton vett részt, szinte nélkülözhetetlenné vált az írás tudománya. A tanulni valók olvasása, az új ismeretek átadása így vált a szaktudás eszközévé, terjedt el a polgárok között. A könyvnyomtatás feltalálásával, és a reformáció elterjedésével megjelenő igény, hogy a Bibliát minél többen tudják olvasni, a latin kultúra helyett a nemzeti kultúrák ugrásszerü fejlődését indította el. A társadalmi érvényesülést, a mủveltséget jelképező írástudás mégsem ekkor, hanem a felvilágosodás eszméinek terjedésével vált nemzeti üggyé. A középkori egyetemek és egyházi iskolák mellett a 18. század végétől kezdve az uralkodók akaratából sorra jelennek meg az egyes országokban a Ratio Educationis rendeletek, azaz az okszerü oktatásügy megszervezésének a rendeletei. Így történt ez hazánkban is Mária Terézia uralkodása idején. Ettől kezdve az oktatásügy nem egyéni, hanem társadalmi jelentősége egyre nagyobb hangsúlyt kapott, és kap napjainkig.

Az újkori oktatási rendszerek közül kétségtelen, hogy az angol iskolák szerveződtek legkorábban, hozzánk azonban a két kontinentális típus hatása érkezett meg. A német iskolarendszert erős állami felügyelet jellemezte, míg a francia iskolatípusokat Napóleon sokkal változatosabbá tette (Tóth, 2008). Így, annak ellenére, hogy a politikai hatások révén elsősorban a porosz rendszer látszott meghonosodni, de éppen a tehetséggondozásban érződött a francia hatás. A tehetséggondozás két elengedhetetlen kelléke a jó tanító és a tehetségekhez igazodó iskolatípus. A magyar oktatás reformja a 19. század második felében ezeket alapozta meg. A népiskolai törvény, amelyet már 1848-ban megfogalmazott tulajdonképp Eötvös József, de csak 1868-ban kezdték megvalósítani azt, végső célja a megkésettség felszámolásához való hozzájárulás. Erre a törvényre alapozódtak további oktatási törvények, és létrejöttek a különböző iskolatípusok, a közép- és felsőoktatási intézményekben megvalósult a klasszikus és a természettudományos képzés kompromisszuma. Ebben a modernizációt szolgáló munkában a magyar tanárok öntevékenységére, ambíciójára is számítottak. Lévén, hogy a korábbi kiváltságokkal járó honorácior lét ugyan átalakult, de nem tűnt el a megbecsültségük, a társadalmi presztízsük, így a magyar tanároknak tere nyílt arra, hogy a közélet meghatározó elitjébe sorolják magukat, és helyenként a polgárság hiányát próbálták pótolni. Különösen 
vidéken volt ez jellemző, ahol az értelmiség a polgárosodásban akár vezető szerepet is betölthetett, és életformájával, értékrendjével példaképként is szolgált. Emellett, vagy épp ebből a habitusból adódóan, a felekezeti és a nemzetiségi kérdések oktatásügyi rendezése kapcsán jelentős feladat hárult a tanítókra, tanárokra, és az általuk megvalósuló kompromisszumos megoldások segítették, egységesítették az egymáshoz és az oktatásügyi politikához a való hozzáállásukat. Az egyes iskolatípusok között ezért nem volt éles harc vagy feszültség, ami még inkább erősítette a tanárok küldetéstudatát és ezzel összefüggésben a megbecsültségét (Kovács, 1978). A felzárkózás iránti igény egyre inkább áthatotta az oktatáspolitika teljes rendszerét, amelynek a jelentőségéről, a legilletékesebbnek, a magyar oktatáspolitika talán legeredményesebbnek tekinthető miniszterének, Eötvös József bárónak a véleményét A magyar gazdasszonyok heti lapjában, 1865-ben megjelent újévi köszöntőjéből idézem:

„Az ellenség, mely velünk szemben áll, nem a pillanatnyi ínség, hanem az elszegényedés, mely ezer háznak küszöbén koczog. Zaj nélkül közelít, nem fokozva fel a rémülés által, melyet okoz, de nem kisebb azért, s bizonyos, hogy ennek csak úgy állhatunk ellent, ha minden ház egy-egy vár leend, mely magát az ellenség ellen külön védelmezi, - s vajon - hogy e hasonlatot folytassuk - nem éppen a gazdasszonyok-e azok, kiktől e váraknak ótalma függ?"

A történelmi szituáció ugyan sokban megváltozott az elmúlt másfél évszázad alatt, de térségünkben, a jelenlegi helyzetben a szegénység, a leszakadás veszélye új formában ismét ezer ház ajtajánál kopog, vagy már hívatlan vendégként befészkelte magát. Eötvös ennek kivédésére a családi életet összefogó asszonyokhoz fordult, amit a magyar nőnevelés történetének, annak sikere ismeretében megértünk, és követendőnek tarthatunk ma is.

Az oktatás hazai innovációján ezért érthetjük a családi életmódváltás támogatását, hogy a családokat szétválasztó munkanélküliségből, elszigeteltségből való kitörést segítsék a megszerezhető tudással, müveltséggel. Erre ösztönöz az az európai védekezési stratégia is, amely a globális versenyben az érdekei védelmében az Európai Unió létrehozásával kívánta magát erősíteni. Ennek bizonyítéka a következő állásfoglalás: „Európa minden lakójának — kivétel nélkül — biztosítani kell az 
esélyegyenlőséget, hogy a társadalmi és gazdasági változás által támasztott igényekhez igazodni tudjanak, és Európa jövőjének kialakításában aktívan részt vehessenek." (Memorandum, 2000) A kérdés ezek után az a mód, ahogyan ennek a célnak a megvalósulását követhetjük az egyes országokban.

\section{A tradíció és innováció összefonódása a nemzetközi oktatási rend- szerekben}

Az oktatási rendszereket a globális verseny arra kényszeríti, hogy minél jobban közelítsenek az egyes szintek egymáshoz, hogy összehasonlítható és azonosan értékelhető eredményeket produkáljanak. Ugyanakkor mégis jelen van egyfajta, kulturális hadviselésnek is nevezhetö hatás, amelynek vesztesei az analfabetizmus mai formájában, a funkcionális analfabéták nagy számában és az erősen differenciálódó színvonalban létező viszonylag nagy tömegek. Ök a fogyasztói társadalomban szükséges minimális ismeretekkel rendelkeznek, akik az informatikát munkaeszközként nem képesek kezelni. A győztesei az elitiskolai oktatásban részesülők, akik a világ bármely táján képesek nyelvi és szakmai intelligenciájukat kamatoztatni. A képlet mégsem ilyen élesen szétváló kontúrokat mutat, hiszen egyre gyakrabban derül ki, hogy a lokális kultúra, az egyes etnikai, vallási közösségekre jellemző értékrend nagyon érzékenyen differenciál. Például abban is, hogy mennyire tartja fontosnak, akár a jövő érdekében történő beruházásnak az oktatást. Kiváltságként differenciál-e vagy mindenkinek elérhetővé teszi a magas színvonalú alapozó kultúra elérését. A ,best practise”-okat, a sikeres módszereket azonban ma már nemcsak Európában, hanem a világ minden táján érdemes keresnünk, noha igaz, hogy az európai nagy oktatási rendszerek utóhatása máig erősen befolyásol bennünket.

Egy ilyen bepillantást tett lehetővé Herskovits Mária (1993), aki már 20 évvel ezelött fontos észrevételeket közölt tanulmányában. Az akkor elkezdett reformok mára értékes eredményeket hoztak, és esetenként kiderült az is, hogy számunkra nem mindig elérhetőek vagy támogatandóak a külföldön bevált módszerek. Ennek eldöntésére különösen hasznosak az OECD országokban készített és rendszeresen közreadott felmérések, összehasonlító elemzések. Vannak a világban kifejezetten a tehetséggondozásra szakosodó szervezetek, ilyenek a WCGT, ECHA, MTT: 
WCGT, World Council for Gifted and Talented = Tehetség Világtanács ECHA, European Council for High Ability = Európai Tehetségtanács MTT = Magyar Tehetséggondozó Társaság

A legtöbb országban a témával foglalkozó szakmunkák a kiváló vagy speciális többlettehetséggel megáldottak kiválasztását és speciális, egyéni úton történő fejlesztését, kibontakoztatását tartja a legfontosabbnak. Ebből a szempontból számunkra a skandináv államok és a finnek oktatáspolitikája bizonyulhat követendőnek. A skandináv államok adottságaihoz hasonlóval nem rendelkezünk, de a szemléletük így is rokonszenves. Nevezetesen nem a kiemelkedőkre koncentrálnak, csakúgy, mint a ,finn-modell”. A modell lényege abban áll, hogy minden gyermek számára az optimális fejlesztést kell biztosítani, ugyan abban a csoportban (Descamps, 2013). Ehhez - ahogy ezt már fentebb megállapíthattuk - megfelelő számú pedagógus szükséges, így lehetővé válik, hogy képesek legyenek kiscsoportos foglalkozások tartására, a különböző adottságú, fejlettségű gyermekek differenciált haladásának az irányítására. A finnek szerint a sikeres módszer lényege, hogy nem a felmérésekre, nem az értékelésekre és a személyek, intézmények közötti versenyre készítenek fel, hanem, hogy eredményeiknek köszönhetően a kibocsátott generációk a lehető leghomogénebbek legyenek.

Következésképpen itt a legkisebb összefüggés az iskolai eredmények és a diákok társadalmi helyzete között, azaz, a családi vagyoni helyzet, a területi különbségek nem determinálják a gyermekek jövőjét. Kétségtelen, erre sokat áldoz az állam, és jelentős önképzéssel tudnak megfelelni a hivatásuknak a pedagógusok, hiszen folyamatosan figyelniük kell, mit kell még tanítaniuk, és ellenőrizniük, a diákoknak mit szükséges még tanulniuk, ismételniük, erősíteniük. A Karunkon a közelmúltban Erasmus ösztöndíjjal tanuló finn hallgató teljesítménye megerősítette az írott beszámolókat. Több nyelven beszél, képes és igényes volt az önálló munkavégzésre.

Hasonló eredményekről olvashatunk a dél-koreai oktatási rendszer kapcsán, ahol szintén mindenkire koncentráló az alapfokú oktatás, magas a készségfejlesztési munka, és jelentős a különböző kultúrákban való tájékozódás érdekében a nyelvek oktatása.

A magyar tehetséggondozás természetesen szép sikereket ért el a legkiválóbbak támogatásában az elmúlt évszázadban. Az ő jelentőségüket korántsem mellőzve, most mégis azokért a gyermekekért kell szólni, akiknek 
beszükülő lehetőségeik akár egy jövőbeni kasztosodást, belső gettósodást eredményezhet. Másrészt meggyőződésem, hogy a leggyorsabban és leghatékonyabban az emberi tudás fejleszthető, ami válságoktól szenvedő korunkban olyan különös töke, amelynek nemcsak a fejlesztésére, hanem a hasznosítására is szükségünk lenne. Éppen ezért a leszakadó, hátrányos helyzetü gyermekek esetében is szükségesek hasonló egyéni módszerek, mint a legkiválóbb talentumok esetében. A kiválasztottak számára müködik hazánkban a Magyar Géniusz Program, és az ehhez kapcsolódó tehetségsegítő szövetkezetek, társulások, hálózatok. Mellette létezik az önhibájukon kívül a tehetségük kifejlesztéséhez támogatásra váróknak az Arany János Tehetséggondozó program. Ugyanígy felfedezhető a kétirányúság a szakkollégiumi programokban is. Összességében azonban mégis valami hasonló módszert kellene megvalósítani, mint finn rokonaink, amihez talán az egyik legfontosabb értéket, a pedagógusok presztízsét, tudását és létszámát kellene fejleszteni.

\section{Irodalom}

Aronson, E. (1987): A társas lény. Budapest, Közgazdasági és Jogi Könyvkiadó

BALOGH L. (2007): Elméleti kiindulási pontok tehetséggondozó programokhoz, Budapest (A Nemzeti Tehetségsegítő Tanács 2007. január 5-6-i tanácskozásához), http://geniuszportal.hu/node/77

BORDIEU, P. (1978): A társadalmi egyenlötlenségek újratermelödése, Budapest, Gondolat Kiadó

DesCAMPS, P. (2013): Az osztatlan elismerést kiváltó finn oktatási modellröl. http://www.magyardiplo.hu/kezdolap/1061-az-osztatlan-elismerest-kivalto-finnoktatasi-modellrl

HaJNAL I. (1933): Írásbeliség, intellektuális réteg és európai fejlődés, Károlyi Árpád Emlékkönyv, Budapest

HERSKOVICs M. (1993) A tehetségfejlesztés útjai és tapasztalatai külföldön, In: Herskovits Mária - Gyarmathy Éva (szerk.) Vissza a holnapba. MTA Pszichológiai Intézet, Budapest.

KovÁCS I. G. (1978): Az értelmiségi keresetek változása (1920-1975), in: Értelmiségiek, diplomások, szellemi munkások, Huszár Tibor (szerk.) Budapest, Kossuth Kiadó

Memorandum on Lifelong Learning. European Commission, Brussels, 30. 10. 2000.

MÖNKS, F.J. (1992): Development of gifted children: The issue of identification and programming. Mönks, F.J. \& Peters, W.A.M. (Eds.) Talentfor the Future. Van Gorcum, Assen/Maastricht 
RENZULLI, J. (1978): What makes giftedness? Reexaming a definition. Phi Delta Kappen

Riesman, D. (1996): A magányos tömeg. Budapest, Polgár Kiadó

TóTH T. (2008): A napóleoni egyetemtöl a humboldti egyetemig.

$\mathrm{http} /$ nyitottegyetem.phil-inst.hu/Tarsfil/kut/tanulm/toth2htm 


\title{
Kelemen Lajos ${ }^{13}$
}

\section{NEVELÉSI STÍLUSOK SZEREPE AZ EMBERI KAPCSOLATOK ALAKULÁSÁBAN}

\begin{abstract}
The goal of this paper is to strengthen the preparedness of the pedagogy/social worker students and also social professional in the field of understanding the formation of human relations. The paper intends to introduce those possibilities that may determine the actual and subsequent human relations of the children in relation to the educational methods of the parents. The first part of the paper gives an interpretation of the notion of educational style. In the second half we also give examples of 8 different styles (referring to Béla Kozék), which can be predictions of possible development paths of human relations.
\end{abstract}

\section{Bevezetés}

Az emberi kapcsolatok alakulása, fejlődése, rendezettsége és megbízhatósága a segítő szakmabeliek munkájának fókuszpontjában állnak. Nem véletlenül, hisz a lelki egészségünk alapját a kiegyensúlyozott társas kapcsolatainkban találhatjuk meg. Szép példáját adja e ténynek Ábrahám Maslow, aki a társas szükségleteket (biztonság, intimitás, szeretet, elismerés, valahova tartozás) alapszükségletként tartotta nyilván. Csak erre az alapszükségletekre épülve jelenhetnek meg a magasabb rendü szükségletek.

A klinikai pszichológia vagy a pszichiátria aspektusából is alátámaszthatjuk feltételezésünket. Gondoljunk arra, hogy a lelki egyensúlyvesztés mögött leggyakrabban az emberi kapcsolatok kudarcai, veszteségei, indulatokat indukáló konfliktusok és egyéb desrtuktív hatások húzódnak meg. Mindezek rendezése a gyógyulást jelentheti a betegek számára.

\footnotetext{
${ }^{13}$ Dr. Kelemen Lajos főiskolai docens, Debreceni Egyetem Gyermeknevelési és Felnőttképzési Kar
} 
Jelen tanulmány célja, hogy a szociálpedagógus/szociális munkás hallgatók és szakemberek felkészültségét az emberi kapcsolatok alakulásának megértésében erősíteni tudja. A tanulmány a szülők nevelési stílusának fényében kívánja feltárni azokat az eshetőségeket, amelyek a neveltek aktuális és későbbi emberi kapcsolatait meghatározhatják. Némiképp emberi játszmák csíráit is felfedezhetjük e hatásokban, melyekre a tanulmány szükségszerüen utalni fog (Berne, 2002).

A szemelvény tárgyalja a különböző nevelési stílusokat, majd ezt követően a klasszikusnak mondható Kozéki Béla-féle nyolc nevelési stílus mindegyikére emberi kapcsolati eshetőségeket kínál az olvasó számára. (Bagdy, 1986)

\section{Nevelési stílus meghatározása és kutatásának rövid áttekintése}

A személyiség kutatásának egyik igen felkapott és divatos területe a szülők, pedagógusok illetve a vezetők nevelési stílusának vizsgálata. A nevelési stílus értelmezése alatt kezdetben elsősorban a nevelők személyiségjegyeinek összegződését értették a kutatók, amelyekre a neveltek jól meghatározható magatartásmódokkal válaszoltak. A későbbiekben azonban bebizonyosodott, hogy a nevelö személyiségjegyei mellett a nevelési helyzet, a pedagógiai cél vagy akár a gyerekek száma, összetétele is meghatározhatja a nevelési stílust. „Következtetésképpen a nevelési stílus a nevelő személyiségjegyei és a nevelés lehetőségei által integrált, a gyermek-nevelő relációban érvényesülő olyan hatásrendszer, mely a gyermekek értékelésének, viselkedésének, csoportosulási tendenciáinak lényegi összetevője.” (Ungárné, 1978: 48). A kutatók egyetértenek abban, hogy a nevelési stílus döntően meghatározza a nevelési folyamatot. Ezzel kapcsolatban számos kutatás is született, amelyek közül a leglényegesebbeket szeretném megemlíteni.

Lewin-Lippitt-White (1939 - citálta: Ungárné, 1978) 5 fós, 10 éves gyerekek alkotta ,training group”-ok létrehozásával igazolták az autokratikus, demokratikus és lassaiz faire vezetési stílus hatásmechanizmusait elsősorban a légkör alakulása szempontjából. Klasszikus kísérletük eredménye, hogy jól elkülöníthető a háromféle vezetési stílus, s jól megragadható mindegyikhez rendelhetően a jellemző csoportlégkör. Lewin és munkatársainak kísérletét számos kutató megismételte, Mérei Ferenc pedig óvodás korú gyermekcsoportra is alkalmazta. Mindegyik kísérlet hasonló eredménnyel zárult, melynek fontos konklúziója peda- 
gógiai szempontból, hogy a demokratikus légkörben érezték legjobban magukat a gyerekek (Kántás, 1971).

Lewin és munkatársainak kutatását több kutató is igyekezett tovább formálni. Anderson és munkatársai (1946 - citálta: Ungárné, 1978) a pedagógusokat két típusba sorolta, uralkodó (dominatív) és együttmüködő (integratív) típusba. Tulajdonképpen a lewini autokratikus és demokratikus vezetési stílust keresztelték át a pedagógus személyéhez jobban illeszkedö terminusokkal.

Tausch (1960) a szélsőséges elkülönítést tartotta fontosnak, s ennek megfelelően nagyon autokratikus; aktív integratív és passzív szociálintegratív típusról ír. Mindenesetre az tény, hogy Tausch felveti a nevelési stílusok árnyaltabb megkülönböztetésének szükségességét, még ha ö maga nem is tett arra kísérletet, hogy háromnál több típusban gondolkozzon.

Ruppert (1959 - citálta: Ungárné, 1978) már négy dimenzió mentén alkotott meg négy nevelési stíluspárt: 1, Alanyi és tárgyi nevelés 2, Tiltó és elkényeztető nevelés 3, Tekintélyi és szabad nevelés 4, Öntudatos és büntudatos nevelés. Ruppert mindegyik stíluspárra vonatkozóan megemlíti a kívánatos ,arany középutas” nevelési stílust: 1, Tárgyilagos nevelési stílus 2, Gondoskodói nevelői stílus 3, A tiszteletet kifejező nevelési stílus 4, Valósághüséget képviselő nevelési stílus.

Becker (1964 - citálta: Ungárné, 1978) a szülői nevelési stílust az érzelmi viszonyulás (meleg-hideg) és a követelménytámasztás (korlátozó-engedékeny) dimenziói mentén ragadta meg, s ezek variációi alapján alkotta meg a hideg-engedékeny, hideg-korlátozó, melegengedékeny, meleg-korlátozó típust. Ezt a felosztást ismerteti Ranschburg Jenő is kiemelve az engedékenység helyes pszichológiai értelmezését: „Amit a pszichológia engedékenység alatt ért, nem egyeztethetö össze sem a gyermeket elhanyagoló, kényelemszeretetböl és közönyböl mindent ráhagyó, sem pedig az olvadékonyan engedékeny, mindent megengedő nevelöi magatartással." (Ranschburg - Popper, 1978: 223).

Kozéki Béla Becker felosztását fejlesztette tovább (Bagdy, 1986). Értelmezésében a három dimenzió: 1. a család emocionális légköre (meleg-hideg), 2. a nevelési rugalmasság (nyílt-zárt) és a 3. a követelményekre vonatkozó határozottság és erő (erős-gyenge). Így nyolc típust különített el: 1. Harmonikus (meleg-nyílt-erős) 2. Liberális (meleg-nyílt-gyenge) 3. Ambiciózus (meleg-zárt-erős) 4. Túlvédő (melegzárt-gyenge) 5. Hideg, demokratikus (hideg-nyílt-erős) 6. Elhanyagoló 
(hideg-nyílt-gyenge) 7. Drilles (hideg-zárt-erős) 8. Diszharmonikus (hideg-zárt-gyenge). E nevelési modellek már árnyaltabban mutatják meg számunkra a nevelők gyermekekhez való viszonyulását, ugyanakkor Bagdy (1986) kiemeli, hogy e modellek ritkán jelennek meg a maguk tisztaságában.

\section{A nevelési stílusok hatása az emberi kapcsolatokra}

A szülők nevelési stílusa a gyermekek számára egy attitűd kialakulását eredményezi a világ, és az emberek megítélése tekintetében. Úgy is mondhatjuk, hogy a szülő sajátos ember- és világképe átöröklődik a gyermek szemléletébe. Következtetésképpen, amilyen a szülő és a gyermek emberképe, az meghatározza az emberekhez való közeledés, viszonyulás minőségét és szándékát. Az alábbiakban a tanulmány azt taglalja, hogy a Kozéki Béla-féle nyolc nevelési stílus milyen jellemzőkkel bíró emberi kapcsolatokat kialakulását determinálja.

\section{Harmonikus (meleg-nyílt-erös)}

E nevelési stílus jellemzője, hogy a szülő szeretetteljesen viszonyul a gyermekhez. A nevelés során bízik a gyermekben rejlő potenciálokban, ami azt jelenti, hogy kellő önállóságot enged a gyermeknek a döntésekben és a cselekvések végrehajtásában. Ugyanakkor indirekt módon segíti a gyermeket a feladatok megoldásában, az önkibontakozásban, az önállósága kialakulásában. Ehhez persze rugalmasságra és kreativitásra van szükség a szülő részéről. Jellemző módon inkább a dicséret, megerősítés eszközét alkalmazza a szülő. Pedagógiai módszerei között a megbeszélés, gyakoroltatás első helyen jelenik meg. Ez az attitűd pozitív és reális önértékelést, kezdeményezőkészséget, sikerorientáltságot eredményez a gyermek személyiségében. Mivel reális a gyermek önismerete, világképe, és az önállósodással egyidejüleg az érdeklödése is erős, ezért nyitott lesz a világ és az emberi kapcsolatok irányában. Emberi kapcsolatait az jellemzi, hogy nem vonja be túlzottan énjét a kapcsolatok rendszerébe, tehát objektíven ismerheti meg az embereket, és érdek nélkül van jelen kapcsolataiban. Képes és hajlamos az empátiára, a segítségnyújtásra, s mindehhez a sikerorientáltságnak köszönhetően jól mozgósítja a környezete erőforrásait. Konfliktusok esetében a kompromisszumos vagy problémamegoldó stratégiát választja, mely mindkét félnek megfelelö. Játszmamentes, letisztult, őszinte emberi 
kapcsolatok jellemezhetik a harmonikus stílusban nevelkedett személyeket.

\section{Liberális (meleg-nyilt-gyenge)}

A szülő szintén szeretetteljesen viszonyul a gyermekéhez. Talán túlzottan is erős szeretettel. Ez eredményezi, hogy nem képes következetes elvárásokat támasztani a gyermekével szemben. Gyenge nevelőerejét jellemzi, hogy csak mosolyog gyakran a tiltások, szabálykiépítések során, aminek köszönhetően nem lesz foganatja a tiltásnak. Ennek köszönhetően a gyermek öntörvényü, ún. elkényeztetett gyermekké válik. Hamar megtalálja a módját, hogyan tudja érzelmileg zsarolni szüleit, amivel mindig eléri célját. Vannak gyerekek, akik még egy-egy pofont is kiharcolnak annak érdekében, hogy a szülö lelkiismeret-furdalást, büntudatot érezzen, s felülbírálva saját tilalmát, zöld utat engedjen a gyermek akaratának. Ez nagyon veszélyes, mert itt valójában a gyermek nevel. Veszélyei, hogy a gyermek nem tanulja meg a szabályokhoz, követelményekhez való alkalmazkodást. Alacsony a feszültségtürö képessége, s mindez agressziót vagy helyzetből való menekülést eredményez (regresszió). Továbbá gond még, hogy nem alakul ki a reális önismerete, mert a szülö túldicséri. Kudarckerülő lesz, ha azt tapasztalja, hogy mások ügyesebbek, vagy neki nehéz egy-egy feladat megoldása. Ilyenkor azonnal menekül a helyzetböl, esetleg agresszív lesz a szüleivel.

Emberi kapcsolataira az erős énbevonódás, az egocentrizmus, önzőség lesz jellemző. Éppen ezért nem képes az empátiára. Önérvényesítési törekvése olyan erős, hogy egy sajátos emberi játszma jellemezheti kapcsolatait. E játszma lényege, hogy olyan társakat, barátokat, partnert választ magának, akiket érzelmi zsarolással magához láncolhat, és ezáltal mindig érvényesülhet a saját akarata. Konfliktusrendezését a versenyző, önérvényesítő stílus jelenti, melyben mindig a felülkerekedésre való törekvés, és nem a közös megoldások keresése dominál. Ha dependens (valakitől való erős függőség) személyek az elkényeztetett gyermek/felnőtt játszmájának szereplői, akkor ők jól szolgálják az öntörvényü egyén érdekeit annak fejében, hogy nekik is jó, mivel nem kell döntéseket és felelősséget vállalniuk. Ök tehát jól kiegészítik egymást a játszmában, és hosszan tartó kapcsolatra rendezkednek be. Ebben az esetben többnyire jól is müködhet a kapcsolati rendszer, bár csak az egyik fél önérvényesítése valósul meg.

\section{Ambiciózus (meleg-zárt-erős)}


Az ilyen stílusú szülők a gyermek jövőképét vízionalizálják maguknak és a gyermeknek, miszerint a gyermekből kitűnő tanuló, sportoló, illetve diplomás szakember lesz. A szülők teremtik meg e jövőképet a gyermeknek, annak ellenére, hogy a gyermek esetleg más célokat fogalmaz meg magának, illetve más jövőre teszi hivatottá képességei, érdeklődése. A szülő bár szereti gyermekét, de ha feladathelyzetről, jövőről, teljesítményről van szó, akkor elvárásai erősek és merevek. Ez a perfekcionalizmus (teljesítményközpontúság), görcsösség, a gyerekkel szembeni empátia hiánya azt eredményezi, hogy a gyermektől irreálisan sokat követel. Ha a gyermek alulteljesít, akkor a szülő frusztrált, csalódott és képes szeretetmegvonással zsarolni gyermekét. A gyermek szenved attól, hogy elveszíti szülei szeretetét, és próbál jól teljesíteni. Azonban ő is görcsössé válhat, debilizáló szorongása alakulhat ki a teljesítményhelyzetekben, és alulteljesítővé válhat. Jellemző rá a kudarckerülés. Gyakran pszichoszomatikus tünetek révén menekül meg a teljesítményhelyzetek elöl.

Emberi kapcsolataira a függőségi viszony, a dependencia jellemző. Nagy benne a megfelelni akarás, azzal együtt, hogy keresi és szereti az intimitást, amely nem a teljesítményhelyzetekről szól. Konfliktusaiban az elkerülő vagy behódoló stratégiát választja, mert így nem szembesül a kudarcokkal, a társas kapcsolati feszültségekkel, melyek szorongást jelentenek számára. Jellemző emberi játszmája, hogy erős egyéniségeket. keres partnernek, barátnak, akik irányítják és elnyomják őt. Ha túlzott egocentrikus személyhez kötődik (pl. elkényeztetett nevelésü), akkor játszmája destruktív, mert mindig elnyomás és érzelmi zsarolás alatt lesz. Ha empátiával bíró erős egyéniségekhez kötődik, akkor játszmája konstruktív, kiegyensúlyozott lehet.

\section{Túlvédö (meleg-zárt-gyenge)}

E stílusban nevelő szülők esendőnek látják gyermekeiket, akik kiszolgáltatottak a világ veszélyeire. Gyakori ez a félelem, szorongás azoknál a szülőknél, akik későn vállalnak gyereket; bizonytalanok a saját szülői szerepükben; vagy átéltek valamilyen traumát, veszteséget. A túlféltés hátterében a túlzott szeretet áll, melyet bizonyos szülői szorongás táplál. A gyermek tehát némiképp áldozata a szülők szorongásának. A szülők szorongásaik oldására szoros kontrollt tartanak a gyermek felett, hogy véletlenül se kerüljön a gyermek veszélyhelyzetbe. E túlzott kontroll fojtogatja a gyermeket önállóságában, kezdeményezésében. Kétfajta reakciót eredményezhet. 
Egyrészt a gyermek azt tanulhatja meg, hogy a világ veszélyes, és ezért mindig is keresi a biztonságot jelentő személyt, akitől minden szempontból függővé válik. E reakció játszmavetülete akár a féltékenységi játszma is lehet, tudniillik ő, mint féltékeny fél kapaszkodik a társába rejtett szeparációs szorongása miatt. Ugyanolyan szoros kontroll alatt felügyeli partnerét, mint ahogyan a túlféltő szülő gyermekét. E játszmában is fojtogató a túlzott kontroll, ami megmérgezi a kapcsolatot.

A másik reakció a lázadás, kitörés lehet. Ekkor a gyermek nem bírja a túlzott kontrollt, és gyakran hazugságok közepette tör ki belőle. Nem beszél öszintén a szüleinek a vele történt eseményekröl, mert akkor tudja, hogy tiltások jöhetnek, melyek fokozzák a kontrollt. Sajnos a későbbi emberi kapcsolataira is igazak lehetnek ezek a megnyilvánulások, és gyakran szintén a féltékenységi játszma kialakulásához vezetnek. Igaz, az előzőhöz képest azzal az eltéréssel, hogy itt a lázadó típusú személy féltékeny partnert választ (persze nem tudatosan), és megint csak a kitörés és hazugságok jutnak osztályrészül számára.

Mindkét esetre igaz lehet, hogy destruktív játszmához vezet, tehát kicsi a remény arra, hogy jól müködő kapcsolatot ápoljanak a túlféltő nevelés alanyai.

\section{Hideg, demokratikus (hideg-nyílt-erös)}

A hideg, demokratikus nevelési stílusra az jellemző, hogy a szülők reálisan ismerik a gyermek képességeit, és biztosítják is számára a kibontakozás, önérvényesülés lehetőségeit. Ugyanakkor túl racionálisak a szülők, mivel az érzelmek megélését nem tartják fontosnak. A szeretet hangsúlyozását, a humort, a mosolyt, vagy akár a gondok kibeszélését nem ismerik a szülők. Ez egy nagyfokú érzelmi deficitet eredményez, melynek következtében a gyermek a pedagógusaihoz, társaihoz túlzottan kötődhet, hogy az érzelmi deficitet kompenzálni tudják. Egy furcsa kettőség áll elő. A feladatok világában racionális, jól boldogul, sikeres, ugyanakkor az érzelmek világában irracionális megnyilvánulásai lehetnek, némi infantilizmus jellemezheti. Az emberi kapcsolataiban gyakran elöfordulhat, hogy a racionális ítéleteit az érzelmek vezérelte irracionalitás felülírja. S ez utóbbi azért erősebb, mert a Maslow-i piramisból tudjuk, hogy az érzelmi szükségletek uralják a teljesítményszükségleteket. Ez a fajta meghasonulás kibillentheti egyensúlyából az egyént, és kiszolgáltatottá teheti az emberi kapcsolatokban. Olyan játszmák áldozatai lehetnek, amelyekben az áldozatokat kihasználják, visszaélnek jóindulatukkal. 


\section{Elhanyagoló (hideg-nyílt-gyenge)}

A szülők számra a gyermek leginkább teher. Saját szükségleteik fontosabbak, mint a gyermekeik szükséglete. Ez azt eredményezi, hogy nem fordítanak időt és figyelmet a gyerekekre. Értelemszerüen nem kapnak szerepet a nevelésben az érzelmek és az elvárások. A gyermek nem tudja bemérni önmagát szülei elhanyagoló nevelése miatt sem érzelmi, sem képességei alapján. Bizonytalan identitásában, éppen emiatt keresi azokat az egyéneket, közösségeket, amelyek révén identitáshoz juthat. A valakihez és a valahova tartozás igénye olyan erös, hogy akár rossz referencia személyeket is választhat, éppen ezért deviálódhat, elkallódhat. Mintha a véletlenen, a szerencsén múlna, hogy kiben tud megkapaszkodni, mert a szocializáció útját, sikerét vagy kudarcát is ez döntheti el. Emberi kapcsolatai is változatosak lehetnek az ilyen egyénnek. Gyakran előfordul, hogy a kapcsolatai felszínesek és nem tartósak.

\section{Drilles (hideg-zárt-erōs)}

A drilles nevelést alkalmazó szülő nagyon kemény elvárásokat támaszt gyermekeivel szemben. Felnőttet lát a gyermekben a tekintetben, hogy nem ismeri a gyermeki szükségleteket, és olyan követelésekkel él, amit egy felnőttnek teljesíteni sem könnyü. Ha a gyermek alulteljesít, akkor a büntetés is kemény. A jutalmazás nem jellemzi ezt a szülöt, mert az érzelmeket elutasítja. A gyermek számára a szülő egy zsarnok, aki csak azt figyeli, mikor hibázik a gyermek, amiért büntethet. Nem csoda tehát, ha a gyermek tele van szorongással. Sajnos azonban ezt a szorongást a társas kapcsolataiban úgy oldhatja a gyermek, hogy ott ő válik zsarnokká, és kemény agresszióval tarthatja sakkban társait. Szorongása azért oldódhat ezáltal, mert az agresszióval feszültségeit vezeti le, ugyanakkor az agresszor szerepben neki nem kell félnie, mert tőle félnek a társak. Rátanulhat azonban így egy antiszociális szerepre, melynek következménye, hogy felnőtt korára az agresszió személyiségjegygyé válik, s gyakran jellemezheti brutalitás az emberi kapcsolatait. Túlzott brutalitása miatt börtönbe is kerülhet.

Emberi játszmáik is a túlzott agresszióról szólhatnak mind szülőként, mind házastársként. A gyermekvédelmi ügyekben gyakran találkozhatunk ezzel a személyiségtípussal és játszmával. Mindig megdöbbenve állunk az olyan esetek előtt, ahol a férj brutalitását a feleség hosszú-hosszú éveken át türi anélkül, hogy kilépne a házasságból. Pedig sok esetben megtehetné. Gyakran tragédiákba torkollanak ezek a játszmák, ahol a feleség is részese a játszmának, hiszen valamilyen rej- 
tett pszichológiai ok folytán brutális férjet választott. Az ilyen feleség elötörténetében is felsejlik egy brutális, drilles nevelési stílusú apa. Ebben az esetben a gyerekek nem az agresszív, hanem a szorongó áldozat szerepében identifikálódtak és nőttek fel. A drilles nevelésnek itt láthatjuk a másik kifutási lehetőségét.

\section{Diszharmonikus (hideg-zárt-gyenge)}

E nevelési stílusra az jellemző, hogy a szülö érzelmileg labilis, és szenved saját maga érzelmi hullámzásától. Éppen ezért nem tud empatikus lenni gyermekeivel, sőt nem tud gyermekei érzelmeire, szükségleteire figyelni. Elvárásai hangulatának megfelelően változnak. Képes egyik pillanatban valamiért dicsérni, s ugyanazért a dologért más alkalommal pedig büntetni. A gyermek a szülők kiszámíthatatlanságát nagyfokú szorongásként éli meg, hiszen nem tudja, mikor cselekszik jót vagy rosszat. Emiatt hajlamossá válhat arra, hogy ő maga is érzelmileg labilis lesz. Gondoljunk csak arra, ha a szülő jókedvében van, akkor a gyermek is jókedvü, felszabadult lesz. Ha viszont a szülö frusztrált, vagy lehangolt, akkor ez fog ráragadni a gyermekre. Sajnos, ha ez beépül a gyermek személyiségébe, akkor ő maga is diszharmonikus szülővé válhat. Ráadásul emberi kapcsolatait is a kiszámíthatatlanság fogja jellemezni. Nehezen fog tudni tartós, elmélyült kapcsolatokat fenntartani labilitása miatt. Nagyon gyakran egyedülinek, magányosnak éli meg helyzetét, ami érzelmi labilitását fokozni fogja. Emberi játszmáiban azok az egyének maradnak meg mellette, akik neveltetésük folytán megtanultak együtt élni a diszharmonikus stílusú személyekkel, tehát esetleg akiknek a szüleik is ilyen stílusúak voltak.

\section{Összegzés}

E tanulmány bepillantást kívánt nyújtani az emberi kapcsolatokat meghatározó nevelési stílusok világába. Bár az egyes nevelési stílusok ritkán fordulnak elő a maguk tiszta formájában, ennek ellenére minden bizonnyal „aha-élménnyel” találkozott az olvasó az egyes stílusok elemző olvasása által. Mindez azért lehetséges, mert a leírt szülői viszonyulásokkal gyakran találkozhatunk emberi kapcsolatainkban így vagy úgy, illetve mi is átéltük, átéljük ezeket a viszonyokat gyermeki/szülői/felnőtt szerepeinkben. 
Az egyes nevelési stílusok személyiségformáló hatásait, s erre épülően az emberi kapcsolatokat meghatározó kivetüléseit még hosszan taglalhatta volna a tanulmány. Amiért nem erre fókuszált az író, annak oka az, hogy az emberi kapcsolatok értelmezéséhez egy kulcsot, egy sémát akart átadni az olvasónak. A nevelési stílusok elemzése által világossá válhat, hogy a gyermek személyisége milyenné formálódik, $\mathrm{s}$ ez milyen kapcsolatokat, esetleg emberi játszmákat eredményezhet. Mindennek megértéséhez, és a kulcs, séma alkalmazásához nagyfokú empátiára van szükség. Ilyeténképpen próbált meg segíteni e tanulmány a segítő szakemberek képzésében, továbbképzésében.

\section{Irodalom}

BAGDY E. (1986): Családi szocializáció és személyiségzavarok. Tankönyvkiadó, Budapest.

BERNE, E. (2002): Emberi játszmák. Háttér Kiadó, Budapest

KÁNTÁs L. (1971): Nevelési légkörök vizsgálata óvodáskorúak csoportjaiban. In: Pedagógiai Szemle, 5. 14-19. o.

Ranschburg J. - PopPer P. (1978): Személyiségünk titkai. RTV-Minerva Kiadó, Budapest.

TAUSCH, A. M., (1960): A nevelők arckifejezésének hatása iskolás gyerekek magatartására szóbeli tilalmak esetén. Kísérletvizsgálat. In: Psychologia 3-4. 255-277. o.

UnGÁRNÉ KOMOLY J. (1978): A tanitó személyiségének pedagógiai-pszichológiai vizsgálata. Akadémiai Kiadó, Budapest. 


\title{
Klement Mariann $^{14}$
}

\section{ALTERNETÍV VITARENDEZÉS AZ ISKOLÁBAN}

ALTERNATIVE CONFLICT-MANAGEMENT IN THE SCHOOL

\begin{abstract}
This present study intends to explore conflicts that arise in school life and depicts different methods that help to handle them effectively. The article presents alternative conflict-managing techniques, from which school mediation and face-to-face restorative method are further discussed. Student mediation, a special interests-based means of communication between parties to a conflict, provides an opportunity for conflict resolution. Restorative techniques help to handle the damage that was caused. The article is recommended especially to those who are interested to learn about new perspectives of looking upon school related conflicts and are looking for efficient means to resolve them.
\end{abstract}

\section{Bevezető}

Megállapítható, hogy a rendszerváltás utáni időszak sok olyan változást hozott a társadalom müködésében, ami az ifjúság életére, müködésére, nagy hatást gyakorol. Ez az időszak egyben teret engedett különböző szubkultúrák, deviáns- és más közösségi normák megszegésén alapuló jelenségek létrejöttének, melyek kezelése új kihívást jelent az ifjúsággal foglalkozó szakemberek számára. Ezen az összetett elvárásrendszernek számos eleme új értelmezést kíván - tudás, nézetek, iskola, tanári szerep- területén. Megváltozott az elvárás-rendszer és megjelentek új paradigmák is, melyek szükségessé teszik a történetileg, kulturálisan megkonstruált tudásnak - az iskolára és gyermekre - és ezeken alapuló hagyományos válaszmintáknak a megreformálását.

Mindezek értelmezése, és a válaszok megfogalmazása aktuális kérdése a pedagógiának és a társadalomtudományoknak.

\footnotetext{
${ }^{14}$ Klement Mariann tanársegéd, Eszterházy Károly Főiskola Szociálpedagógia Tanszék
} 
A konfliktusok okainak, tüneteinek, stratégiáinak és következményének feltárása több tudományterületnek kitüntetett témája. A pszichológián belül is, de a társadalomtudományokban is több tanulmány foglalkozik ezzel a kérdéskörrel. Jelen van a szervezetek életében, az üzleti életben, a munkahelyeken, az iskolákban, s a legkisebb egységben, a családban is. Az iskola alkalmas színtér arra, hogy a gyerekgyerek, és gyerek-felnött között konfliktusok alakuljon ki, ugyanakkor ezek feloldása jó nevelési alkalom is egyben, hiszen itt töltik a gyerekek a legtöbb produktív, tanításra-nevelésre alkalmas időt.

Az okokra és a hatékony kezelés módjára adhatnak választ pszichológiai, szociológiai, pedagógiai elméletek, de kevés olyan eszköz létezik, amelyik ezek ötvözésével próbálja a megoldást megtalálni. Az alternatív vitarendezési technikák interdiszciplinaritásuknál fogva vállalkoznak erre a feladatra.

Ebben a munkában az iskolai élet színterén megjelenő konfliktusokkal, és azok kezelésével foglakozunk, melynek kapcsán olyan alternatív konfliktuskezelési módszerek ismertetésére kerül sor, amelyek alkalmasak iskolai konfliktusok hatékony kezelésére.

\section{A konfliktus meghatározása}

Sokan gondolják azt, hogy a konfliktusok okozzák az emberi kapcsolatok megromlását, a mindennapi életben adódó nehézségeket, azonban a konfliktusok az eltérések, különbözőségek eredményei. Ezek pedig születésünktöl fogva hozzánk tartoznak, ezért nézeteltéréseink is lényünkhöz tartozó adottságként kezelhetők. Ha ezt elfogadjuk, akkor megváltozhat a konfliktusokhoz füződő viszonyunk, és úgy tekintünk rá, mit a problémamegoldás lehetőségének hordozója. Amennyiben kezelésére megfelelő eszközök állnak a szemben álló felek rendelkezésére, elérhető egy magasabb rendü egyensúly, és kialakulhat egy teherbíró, bizalom teli kapcsolat. A konfliktus a békés változás eszközeként is tekinthető.

A konfliktus általános értelemben, egyet nem értés, ellentét, vita vagy feszültség állapota emberek vagy embercsoportok között, ami vélt vagy valós ellentéteken alapul, s mindenki azt szeretné elérni, hogy előnyökhöz jusson. Keletkezésének okai szerint kialakulhatnak informális-, kapcsolati-, érték-, strukturális-, érdekalapú konfliktusok. Az ütközet minőségét meghatározza a konfliktusokkal járó érzelmi színe- 
zet, amely nem minden esetben arányos a konfliktus tétjével, mert befolyásolja a konfliktusban részt vevő egyén személyisége, mentálhigiénés állapota. Továbbá az ütközet minősége attól is függ, hogy milyen indítékok húzódnak a konfliktus mögött. A személyiség szintjén minél magasabb rendü motivációs struktúrához kötődnek, (pl. értékvezérelt meggyőződés, eszmény), annál súlyosabb lefolyásúak, és kevésbé oldhatók meg békésen. Ha alacsonyabb rendü a motivációs struktúra, (pl. kíváncsiság), a konfliktusok annál enyhébb lefolyásúak és annál békésebben oldhatók meg. Boulding K. (1962) meghatározása szerint a konfliktus emberek, vagy emberek csoportjai közötti versengés egy formája. Akkor lép életbe, ha két vagy több személy verseng olyan célokért vagy korlátozott javakért, amelyek ténylegesen, vagy az ő észlelésük szerint nem érhetőek el mindannyiunk számára (Göncz-GeskóHerbai 2001).

Beszélhetünk konstruktív konfliktusról, ami a tisztességes verseny révén serkenti a kísérletezést, a cselekvési alternatívák jobb kiválasztását. A destruktív konfliktus, tisztességtelen versenyhelyzet akkor áll fenn, ha strukturális szempontból egyik fél esélytelen a másikkal szemben, amikor alacsony az egyetértés a követendő szabályokat illetően, és a felek kevésbé bíznak abban, hogy kölcsönösen betartják a szabályokat.

\section{Iskolai konfliktusok}

Munkánk során az a tapasztalat alakult ki, hogy már több évtizede a pályán lévő pedagógusok is egyre kiszolgáltatottabbnak, eszköztelenebbnek érzik magukat. Nem tudnak jó válaszokat arra a megváltozott helyzetre, hogy a gyerekeknek és a szülöknek is vannak jogaik, miközben nekik - néha úgy tünik - már semmihez nincs. A konfliktusok tudatos pedagógiai kezelése fontos nevelési eszköz, nem véletlen, hogy a neveléstudományi diszciplínán belül egyre eröteljesebben jelenik meg az úgynevezett konfliktuspedagógia. Tapasztalható, hogy a pedagógusok jelentős hányadának nem mindig sikerül megtalálnia az adott helyzethez leginkább illeszkedő konfliktuskezelési módot.

Fontos kérdés, s egyben kihívás is az iskola számára, hogy - felgyorsult $\mathrm{s}$ egyre személytelenebb világunkban, ahol fontos a verseny, és az együttmüködés,- olyan személyiségeket neveljen, akik a teljesítmény mellett fontosnak tartják a közösség érdekeit is. Eredményes lenne, ha a tudáson túl, példát állítana az élet minőségének megbecsülésére, az élet tiszteletére. 


\section{Resztoratív modellek}

A resztoratív (kár/helyreállító) igazságszolgáltatás szemlélete nem a büntetésre, a megtorlásra és bosszúra helyezi a hangsúlyt, hanem a közösség jól körülhatárolt érdekei mentén, a kár helyreállítását tüzi ki célul. Célja, hogy a sértő félben megjelenjen a felelősségvállalás, a megbánás és a közösségbe kerülés igénye. Alakuljon ki egyfajta érdekközösség (Herczog 2003).

Ezen modellek struktúrájukban eltérőek abban, hogy ki szervezi és vezeti a megbeszélést, hogy milyen technikákkal bátorítják a részvételt és a résztvevőket, kiket vonnak be az eljárásba, és milyen témaköröket céloznak meg a feldolgozás folyamán.

Az alternetív vitarendezési technikákat az alábbiak szerint csoportosíthatjuk:

- A mediációs modellekre jellemző, hogy a felek kölcsönös megértését helyezi a középpontba, és a felek által elfogadható megoldásokat keres. Többféle mediációs formáról is beszélhetünk (közösségi mediáció, áldozat-elkövető békítés, áldozat-elkövető mediáció), melyek eltérnek egymástól általában a célokban, az eljárás időtartamában valamint abban, hogy ki a folyamat vezetője.

- A konferencia modellek (családi döntéshozó csoport konferenciák és közösségi vagy áldozat- elkövető közötti jóvátételi, resztoratív konferenciák), az érintett felek mellett a hozzátartozók, támogatók és a velük foglalkozó szakemberek bevonásával müködnek.

- A transformatív modelleknél cél az együttélés megalapozása, kialakult sérelmek, igazságtalanságok orvoslásának lehetősége. A resztoratív körök, lehetnek: proaktívak azaz együttmüködést megalapozó, reaktívak azaz itélkező, problémamegoldó vagy sérelmeket-traumákat feldolgozó, gyógyító és kapcsolatokat helyreállító körök (Paul McCold 2003).

\section{A resztoratív szemlélet „Szemtől szembe” módszere}

A ,szemtől szembe” módszer Ted Wachtel (1994) amerikai pedagógus által kialakított Real Justice modellre épül (Herczog 2003). „A resztoratív kimenetelnek, átalakító dimenziója van: az áldozatokat túl- 
élőkké változtatja, a konfliktust együttmüködéssé, a szégyent önérzetté, és az egyéneket közösséggé.”(Győrfi 2002)

\section{A módszer lépései}

A megbeszélés fontos eleme a forgatókönyv, mely egyszerü, és megbízható eszköz a facilitátor (a megbeszélést levezetö) kezében, melyen nem tanácsos változtatni. Lehetőséget kell teremti, hogy a felek kifejezhessék érzelmeiket a tett következményeivel kapcsolatban. A károsultak, áldozatok elmondhassák, mennyiféleképpen volt hatással életükre az, ami velük történt. Szót kapnak az áldozat, és a vétkes családtagjai, ismerősei is, akik gyakran másodlagos áldozatok, sok sérülést szerezve egy-egy ilyen esetben. Már ez is sokkal több, mint amit általában egy hagyományos büntetőeljárás elérhet. A tapasztalat szerint az érzelmek kifejezésre jutnak, veszítenek intenzitásukból. Ha a vétkes felelősséget vállal tettéért, az áldozat dühe, sértettsége, esetleg bosszúvágya gyakran alábbhagy, eltünik. Egymás meghallgatása gyakran önmagában segít megoldani a formális megbeszélés második fontos feladatát: a döntést. A megbeszélés célja, hogy közös döntés szülessen arról, mi történjen a kár jóvátétele érdekében. A harmadik részben az érzelmek, indulatok feloldása történik, ahol lehetőség nyílik az érintett felek közeledésére, spontán bocsánatkérésekre és megbocsátásokra. Gyakran ez a kötetlen szakasz éri el a megbeszélés valódi célját: az indulatok kioldását (Földes 2002, Győrfi 2002).

A megbeszéléseket egy független facilitátor vezeti, akinek nem dolga állást foglalni, de kötelessége biztosítani, hogy minden résztvevő biztonságban érezhesse magát, szót kapjon és kifejezhesse érzéseit. Nyugodt, támogató atmoszférát biztosít, $\mathrm{s}$ a felek figyelmét a megállapodásra összpontosítja. Lehetőséget nyújt, a jelenlévők önkifejezésére, és ösztönzi őket saját kreatív megoldásaik megtalálására (Göncz - Wagner 2003).

\section{A módszer alkalmazása}

A módszert egyre több országban alkalmazzák Európában és a tengerentúlon egyaránt. Az a tapasztalat hogy ezen technikák jól hasznosíthatók, a gyermekekkel, fiatalokkal folytatott munka során. A formális megbeszéléseken kívül még sok más technika tartozik a helyreállító igazságszolgáltatás eszköztárába, melyek nagyon megkönnyíthetik az iskolákban, gyermekotthonokban dolgozók munkáját, és mindazokét, akinek néha gyerekek közti konfliktusokat segítenek megoldani. Az 
iskolában a megbeszélések alternatívaként szolgálnak a kizárással, felfüggesztéssel, eltanácsolással szemben, vagy kritériumként támaszthatók a felfüggesztés utáni visszavételhez. Egy esettel kapcsolatban, egy megbeszélést célszerü tartani. Ha az egyik fél nem vállalja, vagy nem áll módjában részt venni a megbeszélésen, ennek ellenére azt meg lehet tartani. A megbeszélés továbbhaladása érdekében, mindkét félnek bele kell egyeznie a részvételbe, és az elkövetőknek be kell ismerniük tettüket. Ha az áldozat és az elkövető más véleményen van a tényeket, vagy felelősséget illetően, akkor a facilitátor dolga világossá tenni a résztvevők számára a másik fél nézőpontját. Ha az áldozat nem kíván részt venni a megbeszéléseken, ott a facilitátornak kell közvetíteni az áldozat szülei és barátai bevonásával. Az áldozat levelet, képi és hanganyagot, vagy szóbeli üzenetet is küldhet a facilitátoron keresztül (Földes 2002).

\section{A mediáció}

Ez egy speciális konfliktuskezelő eljárás, melynek során két fél vitájában - azok közös beleegyezésével - egy semleges harmadik fél, a mediátor jár közben. A problémamegoldó folyamat keretében a mediátor segít a feleknek, hogy tisztázzák konfliktusuk természetét, segít olyan megoldást találni és kidolgozni, mely mindkét fél számára elfogadható. A megegyezés feltételeiről nem a mediátor dönt, a döntés joga és felelőssége a résztvevők kezében marad. A folyamat során a konfliktusban érintettek és a mediátor közösen tisztázzák a megoldásra váró kérdéseket, feltárják az egyéni és közös érdekeket, amik figyelembe vételével mindannyiuk által elfogadott megegyezéshez jutnak el. A mediációt olyan esetekben célszerü alkalmazni, amikor két vagy több személy között érdekellentét vagy nyílt konfliktus támad, amit nem tudnak konstruktívan vagy belátható időn belül megoldani, valamint szükség van a kapcsolat, a további együttmüködés fenntartására. A közvetítés törekszik a vita jellegének megváltoztatására, a probléma megoldására, reális, müködő megegyezések létrehozására, a felek közötti egyensúly fenntartására, valamint a résztvevőkkel szembeni korrekt eljárásra. A folyamatban résztvevőknek lehetőségük nyílik kommunikációra, érzéseik, ötleteik és megállapításaik kimondására, tárgyalásra, és a saját életükről hozott döntés meghozatalára (Barcy - Szamos 2002). 
A mediációs folyamat hét nagyobb egységre tagolható. Kapcsolatfelvétellel kezdődik, ami a mediáció elindulásával folytatódik abban az esetben, ha ebbe mindkét fél beleegyezett. Ez első találkozás elején fel kell hívni a résztvevők figyelmét, hogy vannak bizonyos szabályok, melyeknek betartása nagyban hozzájárul a mediáció sikerességéhez. Ezek egyrészt a felek magatartására vonatkozó elvárások, az időkeret, másrészt lehetőségek, melyek a közös munka velejárói. A szabályok tisztázását a megszakítás nélküli idő követi, amikor minden fél ismertetheti saját nézőpontjából a konfliktust, anélkül, hogy bárki is közbevágna. Ezt az eszmecsere ideje követi, ahol a felek már párbeszéd formájában beszélnek a vitás kérdésről, és megfogalmazzák igényeiket, érdekeket. Majd a megállapodás kidolgozása következik, ahol kiválasztják a számukra legmegfelelőbb alternatívákat. A végső megállapodás szakaszában írásban rögzítik azt, amiröl a felek megállapodtak. Majd a lezárás szakaszában áttekintik a közösen elért eredményeket (Göncz - Wagner 2002).

A folyamatban a következő alapszabályok érvényesüljenek: a mediáció és a döntés önkéntes, senki sem kényszeríti a feleket semmire. Itt meghallgatják őket, és egymást is meg kell hallgatniuk. Mindenki egyenlő időt és teret kap. Legyenek nyitottak, türelmesek egymás felé, adják meg a kért információkat, ne zárkózzanak el a megoldásra tett alternatívák elöl. Bízzanak egymásban és a mediátorban, tartsák be a titoktartást. Tiszteljék a másikat, ne hibáztassanak, ne használjanak sértő kifejezéseket. A megegyezések bármikor átdolgozhatók, ha nem érzik megfelelönek.

\section{A mediáció előnyei}

A folyamatot végig a felek kontrollálják, a saját érdekeiket maguk képviselik. A kölcsönös elönyöket tartják szem előtt a „győztes-győztes” kimenetelért dolgoznak. A konfliktusok más megvilágításba kerülnek, ezáltal elősegítik új megoldások létrejöttét. A megállapodás betartható, mivel ök maguk dolgozták ki azokat. Ezzel az új személettel az emberek ráébredhetnek, hogy a konfliktusokat békésebben is meg lehet oldani, és annak érdekében ők tesznek lépéseket. Ez a módszer gyors, és lényegesen alacsonyabbak a költségei, mint a bírósági eljárásoké. A felek más helyzetekben is alkalmazható készségeket, szemléletet sajá- 
títhatnak el, tapasztalataik beépülhetnek mindennapi életükbe, viselkedésükbe. Ezzel a folyamattal nincs vesztenivalójuk.

Az iskola állandó modellként szolgál arra, hogy diákok és felnőttek hogyan oldják meg az életben felmerülő problémákat egymás jelenlétében. A viták résztvevőiben a negatív érzések (főként a félelem és az ellenségesség) csökkennek, megtapasztalják a felelősség érzését annak eredményeképp, hogy önkéntesen, öntevékenyen vettek részt saját problémáik megoldásában. A konfliktuskezelök, a diák-mediátorok (akik irányítják, mederben tartják a beszélgetéseket) kompetensebbekké válnak, megtapasztalhatják, hogy vannak olyan képességeik, amelyekkel képesek segíteni másokon, más diákoknak is modellt nyújtanak kommunikációs hatékonyságból és kooperációból. Az ilyen programokban dolgozó fiatalok megtanulnak jobban eligazodni az emberi viszonyokban, az iskolában kevesebb időt kell fegyelmi ügyekkel és problémamegoldással tölteni. Egy idő után csökkennek a konfliktusok, így mindenki többet törödhet a tanulással, javul az iskola légköre: a diákok és a tanárok barátságosabb, oldottabb módon tudnak majd együtt dolgozni. Az iskolai konfliktuskezelési program egy folyamatos erőforrásnak tekinthető, mely kiegészíti az iskolai szabályokat és fegyelmi eljárásokat, más pedagógiai programokat (Barcy - Szamos 2002).

\section{Befejezés}

Az alternatív vitarendezés a pozitív gondolkodásra serkent, amelynek segítségével legyőzhetjük, megoldhatjuk a konfliktusokat. „Sohasem ahhoz kell az igazi elszántság, hogy valakivel perre menjünk, hanem ahhoz, hogy leüljünk vele szemben, s megegyezzünk!” (Csiky 2009)

Ezen technikákat, a gyerekek is képesek elsajátítani, és ha birtokolják és alkalmazzák is azokat, pozitív irányban változik kommunikációjuk, a konfliktusmegoldó képességük. El tudják különíteni a tényeket az érzelmektől, így jobban átlátják az életükben előforduló különféle szituációkat. Szüleikkel, társaikkal, tanáraikkal jobb irányba változna a viszonyuk, javulna a kommunikációs készségük, megtanulnák meghallgatni a másikat, és beszélni saját problémáikról. Az iskolában több olyan helyzet adódik, ahol jól használhatók ezek a technikák és megelőzhetőek a veszekedések, verekedések és negatív érzelmek. Így, nemcsak mint megoldási alternatívát, hanem prevenciós célt lehetne 
használni, hogy a fiatalok megtanulják, a problémát nem elodázni, hanem megoldani.

A poroszos nevelés tekintélyelvü, ami a győztes-vesztes eredményre vezet, és nem mondható hatékonynak. A bemutatott technikák, de már azok elemeinek alkalmazása is hosszú távú eredményekre vezet, mely minden fél kölcsönös érdeke.

A civilizált konfliktuskezelési technika alkalmazása a demokrácia része. Az alternatív vitarendezés technikái ma még meglehetősen újak, ahogy a demokrácia, és a demokrácia müködéséhez szükséges készségek is csak nemrég jelentek meg. Mindezek ellenére munkálkodnunk kell az ilyen típusú szemlélet minél szélesebb körben váló terjesztésén. Annál is inkább, mivel a meglévő kezdeményezések sikerei, eredményei alátámasztják, hogy van rá igény, és egyre inkább megjelenik a szellemi, kulturális nyitottság is. Jelen munkámmal is ennek elősegítésére törekszem.

\section{Irodalom}

BARCY Magdolna - SzAmos Erzsébet (2002): „,Mediare necesse est” - A mediáció technikái és társadalmi alkalmazása. Budapest Animula Kiadó

CSIKY László (2009): Egyezség, avagy a pozitiv gondolkodás eredménye. www. mediator.150m.com

FöLDES Petra (2002): Még egyszer a szemtől szembe módszer iskolai alkalmazásáról. Család, Gyermek, Ifjúság. XI. évf. 31-33.

GÖNCZ Kinga - WAGNER János (2002): Konfliktuskezelés és mediáció. In: Eörsi Mátyás - Ábrahám Zita (szerk.): Pereskedni rossz! Mediáció: a szelíd konfliktuskezelés. Budapest Minerva Kiadó 7-48. o.

GöNCZ Kinga - GESKÓ Sándor - HERBAI István (2001): Konfliktus-kezelés civil szervezetek számára. Budapest Partners Hungary

GYŐRFI Éva (2002): Konfliktuskezelés szemtől szembe - A resztoratív szemlélet érvényesülésének egy lehetséges módja. Család, Gyermek, Ifjúság 2002/4. XI. évf. 8-14.

Herczog Mária (2003): Szemtől szembe a problémákkal és a lehetséges megoldásokkal. In. Herczog Mária (szerk.): Megbékélés és jóvátétel. Budapest, Család Gyermek Ifjúság Kiemelten Közhasznú Egyesület 13-36. o.

MCCOLD, Paul (2003): A helyreállító igazságszolgáltatás elmélete és gyakorlata In. Herczog Mária (szerk.): Megbékélés és jóvátétel. Budapest, Család Gyermek Ifjúság Kiemelten Közhasznú Egyesület 55-131. o. 


\title{
Szerepi Sándor ${ }^{15}$
}

\section{SZOCIALIZÁCIÓ A KISEBBSÉG TÖBBSÉGÉBEN}

\author{
SOCIALIZATION IN MAJORITY OF THE MINORITY
}

\begin{abstract}
This paper is inspired by a former Hungarian-Romanian project and the anthropological research carried out in the Faculty of Child and Adult Education. The author summarises the experiences collected during a research camp organized for the students of the faculty. The goal of the camp was to collect information and experiences in a Romanian village with a Roma community of significant size. The participants had the opportunity to observe the special socialization process, which helps to solve the problems regarding the linguistic incompetence of the Roma pupils. The most specific character of this process is that it is not deliberately planned pedagogically, it is based on the natural processes in the local community.
\end{abstract}

\section{Háttér}

A tanulmány előzménye, inspirációja két forrásból táplálkozik. Az indirekt forrást azok a HURO pályázatok jelentik, melyek 2009 és 2011 között adtak számunkra lehetőséget a Romániai határmenti megyékben (Partium) az antropológiai és pedagógiai kutatásra. Ezek a románmagyar közös pályázatok azt tüzték ki célul, hogy a határ túloldalán élők mindennapjainak megfigyelésével, az abba való bekapcsolódás esélyével hű képet kapjunk a román-magyar határ mindkét oldalán (sokszor inter-, és multietnikus közegben) élők helyzetéröl, kulturális jellemzőikről, még élő hagyományaikról, társadalmi szerkezetükről.

Vizsgálódásainkat mindig két helyszínen végeztük: egyrészt a kulturális antropológia fegyvertárát vetettük be a települések társadalmi és kulturális mélyszerkezetének megismeréséhez és feltárásához, másrészt a

${ }^{15}$ Dr. Szerepi Sándor adjunktus, Debreceni Egyetem Gyermeknevelési és Felnőttképzési Kar 
falusi óvodákban végeztünk pedagógiai tevékenységet. Ez utóbbi kiegészítette, árnyalta az antropológiai vizsgálódások eredményeit, illetve lehetőséget adott óvodapedagógus hallgatóink számára, hogy egy kulturálisan és sokszor nyelvileg is eltérő közegben, más jogszabályi háttérrel is kipróbálhassák eddig megszerzett szakmai tudásukat, és megtapasztalják az interkulturális társadalmak legfőbb sajátosságait (döntően magyarromán, magyar-cigány, magyar-német viszonylatban.)

Ezen alkalmak egyikén a jelen tanulmány által érintett település szomszédságában, Hadadon is jártunk hallgatóinkkal (Debreceni Egyetem Gyermeknevelési és Felnőttképzési Kar). Tehát - úgy gondoltuk nem lesz teljesen ismeretlen közeg számunkra.

A másik (direkt) előzménye vizsgálódásunknak az a pályázati lehetőség, mely 2012 tavaszán került kiírásra a magyar kormányzat részéről azzal a konkrét céllal, hogy a felsőoktatásban tanulók tehetséggondozását segítse elő. Erre reflektálva írtuk meg pályázatunkat (Multietnikus kapcsolatok Hadadon - NTP FTNYT 12), mely elnyerte az értékelök tetszését, így 2012. november végén elindulhattunk a tényleges megvalósítás útján. Bár pályázatunk rövid címében csak Hadad neve szerepelt, ennek ellenére lehetőségünk nyílott a szomszéd település, Hadadnádasd antropológiai és pedagógiai jellegü kutatására is. Ezt elsősorban a hadadi iskolaigazgató segítő szerepvállalásának köszönhettük, aki egyben a hadadnádasdi óvoda müködését is felügyeli.

\section{A település sajátosságai}

Hadadnádasd a romániai Szatmár megye déli részén helyezkedik el, nem messze a megyehatártól (Szilágy megye). Ezt a térséget történetileg a Partiumhoz soroljuk, vagyis szigorúan véve még nem Erdély része. A település meglehetősen távol fekszik mind az gazdasági, mind a közigazgatási központoktól, nem is beszélve a megyeszékhely Szatmárnémeti városától. 


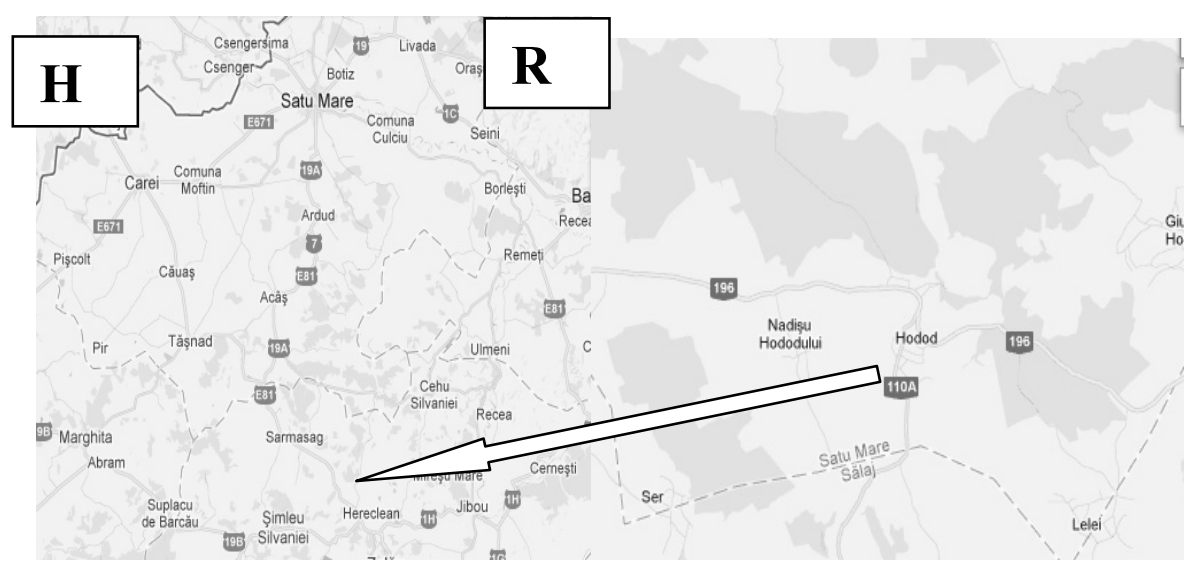

A település adottságai jellemzően nem kényeztették el az itt élőket. A földművelés számára egyáltalán nem ideális talajminőség miatt az agrárium jelenléte lényegében csak a legeltető állattartás területén figyelhető meg. Bányászható ásványkincsekben sem bővelkedik a terület, $\mathrm{s}$ az ipari fejlesztések sem igen találták meg ezt a vidéket. Azonban a turisztika illetve az idényhez kötött vadászat az utóbbi időkben némileg fejlődésnek indult. Ám ennek minőségi és mennyiségi ugrásához még hiányoznak a feltételek (kiszolgáló infrastruktúra, közúthálózat, attitüd).

Ebből következően a lakosság jelentős része vagy állattartással foglalkozik, vagy a közeli nagyobb településeken vállal munkát, s egy jelentős hányad munkanélküliként tölti mindennapjait. Hátrányos helyzetét tovább árnyalja, hogy a falu kb. 900 fös lakosságának egyharmada roma/cigány származású, akik a településen kívül elhelyezkedő telepen élnek. A falut a cigányteleppel egy fél kilométer hosszú földút köti öszsze. A roma közösség tehát „hagyományos” módon szegregáltan él, azonban ugyanúgy használja a község közintézményeit (melyek a település központjában helyezkednek el), mint a többségi társadalom tagjai. Ezek közé tartozik természetesen az óvoda és az iskola is.

Az általános iskola nyolc évfolyamban, évfolyamonként egy osztállyal, míg az óvoda összesen két csoporttal müködik. Mind az iskolára, mind az óvodára jellemző, hogy a roma gyermekek aránya a teljes lakossághoz képest jelentősen felülreprezentált. Az óvodát tekintve ez nagyjából 50 százalékos arányt jelent. Azonban az iskolától eltérően, az óvodai nevelésben résztvevő, azaz beiratkozott roma, cigány gyerme- 
kek egy része nem jár rendszeresen. A hideg beálltával jelentősen csökken az óvodalátogatási aktivitásuk.

A település cigány közösségére jellemző, hogy anyanyelvként az oláh cigány nyelv helyi változatát beszélik. Tehát az a sajátos helyzet figyelhető meg, hogy egy romániai kis faluban a magyar anyanyelvü kisebbség kisebbségeként él egy néhány száz fős roma csoport, amelynek nyelvi szocializációja az óvodába kerülésig kizárólag cigány nyelven történik, míg a magyar gyerekeké kizárólag magyarul. (A magyar gyerekek is csak később, iskolai évek alatt sajátítják el az állam hivatalos nyelvét, a románt.)

\section{A kutatás körülményei}

Kutatótáborunk 2012. november 26. és december 2. között müködött Hadad és Hadadnádasd településeken. Szállásunk a hadadi Wesselényi kastély erre a célra kialakított részében volt berendezve. Csapatunkat 6 oktató illetve óvodapedagógus kolléga, valamint 15 óvodapedagógus hallgató alkotta. A hallgatók között megtalálható volt négy vajdasági diák is, akik ez idő alatt vendéghallgatóként vettek részt a tábor tevékenységeiben.

A kutatómunka egyrészről a már említett négy terepen folyt:

- Cigánytelep, Hadad

- Óvoda, Hadad

- Cigánytelep, Hadadnádasd

- Óvoda, Hadadnádasd

A kollégák közül ketten négy óvodapedagógus hallgatónk részvételével a hadadnádasdi óvodában végeztünk pedagógiai szakmai munkát. Megérkezésünk előtt, még a tervezési, elökészületi munkálatok során kitűztük tevékenységünk célját: óvodapedagógiai gyakorlat végzése eltérö szocializációs, és részben eltérö nyelvi és kulturális közegben - a tapasztalatok feldolgozásával. Azonban a terepre érkezve szembesültünk egy olyan váratlan körülménnyel, ami megtartva eredeti célunkat egy új, más irányú vizsgálódási cél megfogalmazását inspirálta bennünk: sajátos nyelvi inkompetencia, s az ebböl következö szocializációs sajátosságok megfigyelése roma-magyar interkulturális közegben. 
Az óvoda mindkét csoportja vegyes életkorú gyermekek nevelését, fejlesztését látja el, kizárólag magyar nyelven. Csoportonként 1-1 óvodapedagógus végzi pedagógiai tevékenységét reggel 8 órától ebédidőig. 12 óra és fél 1között a gyermekek egy része egyedül indul haza, másokért pedig valamelyik családtag jön el. Az óvodai élet ezért értelemszerüen csak a délelötti időtartamra zsugorodik, nem tartalmazva sem az ebéd-, sem az alvásidőt. ${ }^{16} \mathrm{Az}$ óvodák ugyanúgy tanterv alapján végzik pedagógiai munkájukat, mint az iskolák, természetesen az életkori sajátosságoknak megfelelő cél- és tevékenységrendszert hozzárendelve. Persze a mindennapi élet a romániai óvodákban is tartalmazza a szabadjátékot ${ }^{17}$, azonban a kötelező foglalkozások hangsúlya ugyanolyan erős manapság is, mint azt a hazai óvodai felfogásban a '90-es évek előtt tapasztalhattuk. Vagyis egyszerüen fogalmazva: hallgatóinknak egy sajátos helyzettel kellett megküzdeniük hadadnádasdi munkájuk során, melynek jellemzői:

- Eltérő szakmai háttér (alapprogram és helyi program helyett központi óvodai tanterv),

- Eltérö szokások, hagyományok az óvodai nevelésben,

- Magyar mint anyanyelv,

- Eltérő társadalmi közeg (szegényesebb falusi miliő),

- S egy nem várt eltérés: a roma/cigány gyerekek nyelvi inkompetenciája voltak.

\section{A nyelvi hátrányok kérdése}

„Az iskolai kultúra ... teljességgel haszontalan a cigány kultúrán belül mind társadalmi, mind gazdasági szempontból: Társadalmi szempontból azért, mivel a cigányoknak saját kultúrájuk van, saját szabályokkal és értékekkel, és a gádzsó kultúra ismerete (azaz az írni-olvasni tudás) semmilyen presztízzsel nem jár a cigány társadalmon belül." (Zatta, 2206:351). A többségi társadalom által beszélt nyelv részleges vagy töredékes elsajátítása sok inter- és multikulturális társadalmi képletre jellemző szerte a világban. (Ld. Az Egyesült Államok déli államiban élő spanyol anyanyelvűek redukált angol tudását.) Ez a jelenség annál

\footnotetext{
${ }^{16}$ Ez a típusú óvodai működés a napirendet tekintve általánosnak mondható az általunk látogatott romániai intézményekben.

${ }^{17}$ Bár hozzá kell tenni, hogy ez nem feleltethető meg a magyar gyakorlatnak.
} 
erösebb., minél zártabb a kisebbség a többség irányában illetve minél erösebb, szívósabb kulturális hagyomány és értékrend adja meg az alapját. Ily módon tapasztalhatunk nyelvi problémákat egyebek között a Romániában élő székelyek körében is, ami a közép- és felsőfokú oktatásban jelent hátrányt elsősorban a fiatalok számára.

Azonban a cigány/roma kisebbség esetében mindehhez hozzájárul a fenti idézetben is pontosan megfogalmazott jellemző: a többségi kultúra iránti érzéketlenség, érdektelenség, vagy pontosabban a többségi kultúrához való tényleges és mély társadalmi integráció felvállalásának töredékessége vagy hiánya. Ebben a tekintetben a magyarországi illetve a romániai cigány közösség és a többségi társadalom tekintetében nem érzékelhető lényeges különbség. Viszont az általunk vizsgált hadadnádasdi helyzet két olyan elemmel bővíti a problémát, ami a hazai gyakorlatban nem figyelhető meg:

- A roma közösség elzártsága nem csak földrajzilag, társadalmi szempontból, hanem nyelvileg is elszigetelödést teremt. Ez a szegregáció azt jelenti, hogy a felnövekvő generáció tagjai az intézményes nevelésbe kerülésig (óvodai beiratkozás 3-5 éves korban) gyakorlatilag csak a saját cigány nyelvet (romani) beszélő közösség tagjaival érintkeznek, tehát a többség nyelvet (jelen esetben elsődlegesen nem a román, hanem a magyar nyelvet) majd csak az óvodai nevelés éveiben sajátíthatják el.

- A romániai óvodai nevelési gyakorlat kevéssé rezonált az elmúlt évtizedekben arra a kihívásra, amit a többségi társadalmon belüli roma populáció aránynövekedése jelent. Vagyis: nem tekintik megoldandó problémának az egynyelvü cigány gyermekek nyelvi beillesztését, a kommunikációs gondok tudatos kezelését, egyszóval a nyelvi inkompetencia oldását. E helyett azokra a „természetes” folyamatokra hagyatkoznak, amiket hagyományosan az intézménybe kerüléskor figyelhetünk meg, s amikről az alábbiakban lesz majd szó. Az óvodapedagógusok tájékozottsága is minimálisnak tekinthető a cigány kisebbség életével, körülményeivel kapcsolatban, így arra a kérdésre sem tudtak válaszolni, hogy milyen cigány (romani) dialektust beszélnek a hadadnádasdi cigányok. Viszont azt megfigyelhettük, hogy a roma gyerekek nevei többnyire magyar eredetủek, azaz névadási gyakorlatukban elsősorban a helyi többségi társadalom szo- 
kásrendszerét, illetve a faluban erőteljesen jelen lévő baptista egyház által inspirált ószövetségi neveket preferálják.

\section{Nyelvi inkompetencia és óvodai nevelés}

Kutatótáborunk hét napjából négy munkanapot tudtunk a pedagógiai gyakorlatra és az óvodában elöforduló pedagógiai, szocializációs helyzetek tanulmányozására fordítani. Ennek az oka az volt, hogy első napot (hétfö) a településsel és az intézményekkel való ismerkedés töltötte ki, míg a hétvége ebből a szempontból értelemszerüen kiesett.

A két óvodai csoportban 2-2 hallgatónk végzett gyakorlati munkát, foglalkozásokat szervezve és vezetve. A nyelvi inkompetencia megfigyelése ezeket a helyzeteket felhasználva vált a kutatás szerves részévé. Összesítve a következő szocializációs helyzetek képezték a megfigyelésünk alapját:

- Az óvodapedagógus által indukált kommunikáció,

- Óvodapedagógus hallgatóink foglalkozásai,

- Játéktevékenység során megfigyelt helyzetek.

Mindkét csoportban hasonlóan alakult a közösség szerkezete:

- Magyar származású gyerekek, akik többsége rendszeresen jár óvodába,

- Cigány, roma származású gyerekek, akik rendszeresen járnak óvodába,

- Cigány, roma származású gyerekek, akik óvodai részvétele csak alkalomszerü (függvénye az időjárásnak, illetve nagyobb ünnepeknek).

A hét folyamán megfigyelhető volt, hogy két olyan körülmény miatt, mely épp akkor volt jelen az óvodában, a gyerekek viszonylag nagy létszámban voltak jelen. Az egyik ok a Mikulás ünnepségre való készülődés, a másik pedig a mi ottlétünk, amely meglehetősen nagy változást jelentett eddigi életükhöz képest. Ettől függetlenül mégis volt mindkét csoportban 2-3 olyan gyermek, aki nem jelent meg az ott eltöltött nap mindegyikén az óvodai csoportban. 
A roma gyerekek életkora döntő jelentőségü a nyelvi felzárkózás szempontjából. A nagycsoportos cigány gyerekek iskolába kerülésükre már gyakorlatilag teljes mértékben elsajátítják a magyar nyelvet. A folyamat két-három évig tart, s a megfigyeléseink alapján a következő módon, utakon zajlik:

a. Az óvodapedagógus problémakezelési stratégiája:

- Amennyire képes rá, s a helyzet megengedi egy gyermeket sem hagy ki a tevékenységekből. A nyelvet nem értő cigány gyerekeket is ,megszólítja”, odavezeti, nonverbális instrukciókkal látja el. Az intonációval, gesztusokkal kísért magyarázataival próbálja folyamatosan bevonni őket a foglalkozásokba.

- Olyan „tolmácsokat” használ, akik fordítanak magyarról cigányra és vissza is. Ezek a tolmácsok olyan már általában nagycsoportos roma gyerekek, akik a 2-3 óvodai év alatt elsajátították a többségi magyar nyelvet, $\mathrm{s}$ valamilyen közeli kapcsolatban állnak a magyart nem értő kicsikkel (testvér, unokatestvér, távolabbi családtag, az utcában lakó...). Ezek a tolmácsok megfigyeléseink szerint általában két esetben aktivizálják magukat:

- Ha az óvodapedagógus megkéri őket erre, mert ő maga már egyedül nem boldogul a kommunikációs helyzetben.

- A magyart nem beszélő kicsi kerül olyan helyzetbe, mikor a nagyobb gyermek nyelvileg kisegíti.

- Az óvónő a magyar nyelv használatát „,szorgalmazza”. Ez lényegében azt jelenti, hogy a cigány gyerekek egymást közti anyanyelvü magánbeszélgetéseit igyekszik megakadályozni, hiszen egyrészt ezekben a szituációkban nem érti a kommunikáció tartalmát, ami zavarja, másrészt pedig azt gondolja, hogy ezek a cigány nyelvü beszélgetések hátráltatják a magyar nyelvi kompetencia megszerzését. Mindebből következően rendszeresen rá is szól a cigány nyelvet „kontrollálatlanul” használókra.

b. A gyermek problémakezelési stratégiái:

- Bekerülése után egyre tudatosabban használja a tolmácsokat. Az otthoni környezetből ismerös gyerekekre való támaszkodás az első napoktól kezdve jellemző, viszont a 
nyelvi kommunikáció segítésében betöltött funkciójuk fokozatosan válik elengedhetetlenné, s majd az évek alatt elhagyhatóvá.

- Folyamatosan figyel mindent és mindenkit, hiszen jellemző módon csak az események, tevékenységek szoros követéséböl tud következtetni arra, hogy mi is történik az óvodai csoportban. Ezt jól megfigyelhettük a magyar nyelvü mesemondás során is, ahol a roma kiscsoportos kisgyerekek felváltva figyeltek az óvónő intonációra, gesztusaira és egyéb nonverbális kommunikációs jeleire, illetve óvodástársaik reakcióra. Mindeközben a mesehallgatást egyetlen alkalommal sem zavarták meg, ami igaz volt egyéb tevékenységekre is.

- Igyekszik a nem verbális alapú vagy irányítású tevékenységekben minél intenzívebben részt venni. Itt elsősorban az asztalnál végzett manuális tevékenységekről van szó. Hiszen itt közvetlenül tudja a mintát követni, amit társai mozdulataiból les el.

Ehhez a sajátos kommunikációs gyakorlathoz két olyan feltétel teremti meg az alapot, melyeknek hiányában minden valószínűség szerint egész máshogy müködne az óvodapedagógus és a roma gyerekek kapcsolatrendszere.

- A cigány gyermek (és szülők) erös biztonságérzete az óvodai közegben. Megfigyelhető volt, hogy nemcsak a nagyobb (tehát már 1-2 éve az óvodai közegbe, s ezzel a többségi magyar társadalomba szocializálódott), hanem a nem sokkal korábban bekerült, a magyart nem beszélő kisebbek is teljes mértékben biztonságban érezték magukat az óvodában, és saját csoportjukban. Ennek hátterében természetesen a roma szülők bizalma is kitapintható, aminek hiányában a cigány gyerekek jelenléte jóval kisebb arányú lenne. (A roma szülöket kevéssé befolyásolja, illetve ösztönzi a szociális ellátó, illetve gyermekvédelmi rendszer az óvodai nevelésben való részvételre, mint Magyarországon. Ezért ezt akár nagyobb mértékben is belső motivációnak tekinthetjük.) 
- Az óvodapedagógus elfogadó attitüdje. Mindkét általunk megismert óvodapedagógusra jellemző volt munkájuk során a maximális elfogadás a roma gyerekeket tekintve. Ez az attitüd tette elsősorban lehetővé azt a sajátos szocializációs gyakorlatot, mely a nyelvi inkompetencia alapállásából három év alatt eljuttatja a cigány óvodás gyermeket az iskolaérettség küszöbéig. Lényegében kompenzálva a sajátos családi szocializációból, és eltérő anyanyelvből származó hátrányok jelentős részét.

\section{Záró gondolatok}

Kutatótáborunk alatt egy a várt eredmények (tapasztalatok egy a magyar óvodai gyakorlattól eltérő közegben, a falu cigány közössége jellemzőinek megismerése) mellett egy váratlan hozadékra is szert tettünk. Megfigyelhettük azt a sajátos szocializációs folyamatot, mely a falu határában élö cigány közösség óvodába kerülő gyermekeinek nyelvi inkompetenciáját oldja fel folyamatosan, minden különösebb tudatos és tervezett pedagógiai hatás nélkül, pusztán a természetes folyamatokat hagyva érvényesülni. Nem tisztünk értékelni ezt a „megoldást”, csupán rögzíteni igyekeztünk a fenti gyakorlat föbb jellemzőit, kifejtve mindazokat a körülményeket, melyek között mindez müködhet. Végül, a Hadanádasdon tapasztaltakra rímelnek a következő sorok is: „A cigány gyermekek többsége nagycsaládban él, ezért nyitott a közösségi kapcsolatokra. Szociálisan fejlettek, ennek ellenére - valószínüleg a társadalmi kirekesztés régi „hagyományai” miatt - tartanak az idegenektől, de tapasztalatok szerint akár egyetlen cigány gyermektárs jelenléte is elég ahhoz, hogy bátorságukat, barátkozó hajlamukat visszanyerjék. Leginkább testvéreik, családjuk, rokonságuk körében érzik magukat biztonságban, s megtapasztalták, hogy a családi összejövetelek alkalmával, mint kisgyermekek ök állnak a figyelem középpontjában. Ezért a cigány gyermekek óvodai beilleszkedését a testvérek, az idősebb gyerekek, a családtagok, a távolabbi rokonok jelentősen segíthetik." (Kovács, 2009:113).

\section{Irodalom}

EMERSON, Martin (1999): Roma Education in Eastern and Central Europe - some personal reflections. In.: Intercultural Education, 10: 2, 201-206. 
Hátrányos helyzetü 3-7 éves gyerekek integrált óvodai nevelése. A Biztos Kezdet program háttértanulmányai (2012) Educatio Társadalmi Szolgáltató Nonprofit Kft. Budapest

HIDASI Judit (2004): Interkulturális kommunikáció. Scolar kiadó, Budapest

Ismeretek a Romológia alapképzési szakhoz (2006) (szerk.: Forray R. Katalin) PTE BTK NTI Romológiai és Nevelésszociológiai Tanszék, Pécs,

KovÁcs László: Cigány gyerekek, óvoda, család (2009). In.: Megismerés és elfogadás. (szerk.: Kállai Ernő, Kovács László) Nyitott könyvműhely, Budapest

TORGYIK Judit - KARLOVITZ János Tibor (2006): Multikulturális nevelés. Budapest /www.uni-miskolc.hu/ btntud/multikult.pdf

ZATTA, Jane Dick (2006): Szóbeli kultúra és írásbeli kultúra. In.: Cigány világok Európában. Nyitott Könyvmühely Kiadó, Budapest 


\title{
Nistor Mihaela ${ }^{18}$, Martos Tamás ${ }^{19}$, Molnár Péter ${ }^{20}$
}

\section{„CSAK AZT SZERETNÉM, HA SZERETNÉTEK!” A KÖTŐDÉS ÉS A CSALÁDI MINTÁK HATÁSAI A PÁROS MEGKÜZDÉSRE}

\author{
„I JUST WANT YOU TO CARE OF ME!” THE EFFECTS OF \\ ATTACHMENT AND FAMILY PATTERNS ON DYADIC COPING
}

\begin{abstract}
Family is the first place where the individual learns the ways to espress affections, this patterns are transfered then to close relationships. The way we cope with conflicts in relationships is fully reflected in the family learned behavior patterns.In the present study, our aim is to present the role of the family patterns (highlighted the adult attachment and the role of dyadic coping) on the relationship satisfaction. According to this we illustrate the relationship between the attachment, dyadic coping and satisfaction in couple relationships. In our questionnaire based study 64 adults participated who had a partner (32 men and 32 women, mean age of the sample is 24.91, standard deviation 3.67 years). In addition to the Relationship Questionnaire (Csóka et all, 2007), with which we have tried to capture the attachment experiences, we assessed also The Dyadic Coping Inventory (Martos, Sallay, Nistor, Jozsa, in press) to measure the dyadic coping type and the Marital Stress Scale (Balog et al, 2006; modified version). to measure the relationship satisfaction. As a result of this study it can be concluded that, although the anxiety is associated with low relationship satisfaction, delegated coping lead to a higher relationship satisfaction. Consequently, if an individual is able to change the patterns of his family and adopt new coping patterns with his partner
\end{abstract}

\footnotetext{
18 Nistor Mihaela Ph.D hallgató, óraadó, Debreceni Egyetem Pszichológiai Intézet Gyermeknevelési és Felnőttképzési Kar

${ }^{19}$ Dr. Martos Tamás egyetemi docens, Semmelweis Egyetem Mentálhigiéné Intézet, Budapest

${ }^{20}$ Prof. Dr. Molnár Péter egyetemi tanár, Debreceni Egyetem Magatartástudományi Intézet Népegészségügyi Kar
} 
increases relationship satisfaction, contributing to the future of their offspring to develop a harmonious family patterns.

\section{Kötődés és megküzdés: a diszfunkcionális családi minták átadása nemzedékról nemzedékre}

A kötődési elmélet (Bowlby, 1973, Hazan, Shaver, 1987) ad egy jól értelmezhető keretet ahhoz, hogy megértsük az individuális különbségeket a stresszel való megküzdésben. A különböző kötődési stílusokkal rendelkező személyek különböző stratégiákat választanak ahhoz, hogy megküzdjenek a stresszel. A választás függ a családban kialakult kötődési tapasztalatoktól (Bartholomew, Horowitz, 1991). Számos kutatás bebizonyította, hogy a biztonságosan kötődő emberek általában a szeretet, elkötelezettség magas szintjén állnak, ami lehetővé teszi, hogy konfliktus esetén konstruktívan viselkedjenek (Simpson, 1992, Kobak, Hazan, 1991). Ezzel szemben a félelemtéli és tagadó elkerülö kötődési stílusú emberek inkább a kevésbé konstruktív konfliktuskezelésre hajlamosak - például negatív érzelemkitörésekre (Steuber, 2005, Pietromonaco, 2004). Ha a korai években az egyén megtapasztalta a családjában a biztonságérzetet és kötődési szükségletei kielégültek, ez a bíztonságos kötődés élete végéig kíséri majd az illetőt. Hasonló meghatározó élménnyé válik az is, ha a személynek elhanyagoló, vagy elutasitó szülői magatartásban volt része. A diszfunkcionális minták hatlépésen keresztül öröklődnek generációtól generációra.

Aki ilyen diszfunkcionális családi mintákkal rendelkezik, nagy valószinüsséggel ezek körül fogja felépiteni a párkapcsolatát és a családi életét is. Ha az illető nem képes változtatni ezeken a mintákon, és új megküzdési mintkat alakitani, nagy valószinüsségel olyan párkapcsolatokat fog kialakitani amely kudarcba fulladnak (Townsend, 2011).

\section{Bodenmann elmélete a páros megküzdésról}

De hogyan lehet változtatni, tudatosan dolgozni ezeknek a megküzdési mintáknak a változásában és közösen a partnerrel kialakitani olyan mintákat, amelyek növelik a párkapcsolati elégedettséget? Erre ad választ Bodenmann (2005) elmélete a páros megküzdésról. A párkapcsolati konfliktusok közös jellemzője, hogy mindkét partner 
stresszhelyzetként értékeli a helyzetet, és együtt járulnak hozzá egy olyan megküzdési mód kialakításában, amely nem feltétlenül eredményes. Ezt a partnerek által közösen kialakitott megküzdési folyamatot nevezzük páros (diádikus) megküzdésnek. (Martos, 2008). A diádikus megküzdésnek vannak pozitív és negatív formái. A pozitív diádikus megküzdés típusai a következők:

A támogató diádikus megküzdésben az egyik fél kézzelfogható eszközzel, vagy érzelmi támogatással segíti a partnerét anélkül, hogy magát a megküzdési munkát magára venné. Közös diádikus megküzdésről azon esetekben beszél, mikor mindkét félnek a kapcsolat szempontjából fontos céljai kerülnek középpontba. Az átvállalt diádikus megküzdés az egyik partner azon lehetőségét jelenti, hogy a másiktól átvegye a feladatot, amivel meg kellene küzdenie.

A diádikus megküzdés negatív formái pedig a következők:

Ambivalens diádikus megküzdés esetén a partner támogatását a támogató fél szükségesnek érzi, ezért meg is teszi, de a fél ezt a maga részéről megterhelőnek, kellemetlennek éli meg. Elutasitó diádikus megküzdésről beszélünk abban az esetben, amikor a partner stressz jelzéseire közvetlen visszás megnyilvánulásokat produkál a másik fél. Felszínes diádikus megküzdés esetén, pedig a felajánlott támogatás színlelt.

Bodenmann vizsgálatai demonstrálták, hogy a páros megküzdési készségek eredményesen taníthatók, fejleszthetők. Következtetésképpen még azok a személyek is akik diszfunkcionális kötődési mintákat fejlesztettek a családban képesek átalakitani mintáikat, ha tudatosan dolgoznak rajta. Mivel az eredményes megküzdés mindkét félnek a befektetett munkáján mulik, a páros megküzdés rendszerszemléletü elmélete különös jelentősséggel bír. Ezért fontosnak tartjuk megvizsgálni, hogy a páros megküzdés minősége növelheti-e a kapcsolati elégedettséget azon személyek körében akik nem megfelelő családi kötődési kapcsolatokkal rendelkeznek.

\section{A vizsgálat célja}

A páros megküzdéssel foglalkozó kutatások többsége amerikai, illetve svájci párok részvételével zajlott. A mi kutatásunk célja, hogy az előbb említett eredményekre támaszkodva megvizsgáljuk azt, hogy a Magyarországon élő párok, hogyan viszonyulnak a diádikus megküzdéshez. A párkapcsolati elégedettséget már több vizsgálatban is összefüg- 
gésbe hozták a diádikus megküzdéssel, de a kötődési stílus kapcsolatát a páros megküzdéssel még senki sem vizsgálta. Ugyanúgy a páros megküzdés, elégedettség, kötődés együttes kapcsolatát sem vizsgálta senki. Ennek következtében, az a célunk, hogy egy modell segítségével szemléltessük, hogy a kötődési stílus befolyással van a megküzdési stratégia kiválasztására, illetve ez utóbbi hatással van a párkapcsolati elégedettségre.

\section{Hipotézisek}

Hipotéziseink a felnőtt kötődés, páros megküzdés és elégedettség együttes viszonyára irányulnak. Feltételezzük, hogy mind a függetlenség, mind az aggodalmaskodás dimenziók magas értékei negatív összefüggésben fognak állni a kapcsolati elégedettséggel. Ezzel szemben a kapcsolatkeresés, ami a biztonságos kötődés jellemzője, pozitív összefüggést fog mutatni a kapcsolati elégedettséggel.

Továbbá, a pozitív páros megküzdés (jobb stressz kommunikáció, támogató, közős, átvállalt megküzdés) alkalmazása magas párkapcsolati elégedettséget fog maga után vonni. A negatív páros megküzdés, alacsony kapcsolati elégedettséggel fog járni. Ugyanakkor a pozitív támogató megküzdés, illetve a közös páros megküzdés nagyobb mértékben fog elöfordulni olyan személyek körében akik keresik a kapcsolatokat. Továbbá az aggodalmaskadó személyeknél nagyobb lesz az átvállalt megküzdés előfordulásának mértéke annak reményében, hogy ezzel nyerik el partnerük tetszését.

A feljebb feltételezett összefüggések alapján, a következő kérdések merülnek fel a kötődés, a megküzdés, az elégedettség együttes kapcsolatára nézve: Az aggodalmaskodás és az elégedettség kapcsolatát mediálja-e az átvállalt megküzdés? A kapcsolatkeresés és az elégedettség kapcsolatát mediálja-e a pozitív megküzdés (vagyis támogató, illetve közös megküzdés)? A függetlenség és az elégedettség kapcsolatát mediálja-e a negatív megküzdés?

\section{Vizsgálati módszerek}

Vizsgálatunkban három kérdőívet vettünk fel. Az első a Kapcsolati kérdőív (Relationship Scale Questionnaire, RSQ; Griffin és Bartholomew 
(1994; magyar változata Csóka és mtsai, 2007) volt amely a felnőtt kötődés mérésére szolgál. Bartholomew elmélete alapján a biztonságos, aggodalmaskodó, tagadó-elkerülő és a félelemteli elkerülő kötődési mintázatok mérésére alkalmas. A kérdőív 17 tételt tartalmaz. Három alskálája van: függetlenség, aggodalmaskodás, kapcsolat.

A második kérdőív a „Házassági stressz kérdőíve” volt (Balog és mtsai, 2006) amely a pár kapcsolati minőségét méri. Ezzel a kérdőívvel a párkapcsolati elégedettséget kívántuk megragadni. A skála 17 tételt tartalmaz, a faktoranalízis során öt dimenzió különült el: 1.Szeretetbizalom dimenzió. 2.Probléma dimenzió. 3.Szexualitás dimenzió 4. Szívbetegség hatása a szexualitásra 5. Személyes identitás dimenzió. A saját vizsgálatomban a 4. dimenziót (Szívbetegség hatása a szexualitásra) kihagytam, mivel az a szívbetegekre nézve volt lényeges.

A harmadik kérdőív a „Páros megküzdés kérdőíve” (Dyadic Coping Inventory, DCI) amely a pár közös megküzdési stílusának minőségét méri. A kérdőív 37 tételből áll és kilenc alskálája van. Az alskálák aszerint csoportosíthatók, hogy a kérdőív kitöltője saját részéről, a partnere részéről vagy a közös részről megtapasztalt megküzdést értékeli. Az általam használt alskálák a következők voltak: A saját pozitív páros megküzdés, ami magába foglalta a saját stressz kommunikációt, a támogató diádikus megküzdést saját részről és az átvállalt diádikus megküzdést saját részről, a saját negatív diádikus megküzdés, illetve a közös megküzdést.

\section{Vizsgálati személyek}

Vizsgálatunkban összesen 64 párkapcsolatban élö személy vett részt, ebből 32 fiú, 32 lány. A személyek kiválasztásának feltétele az volt, hogy legalább 2 éve éljenek párkapcsolatban, ne legyenek gyerekeik és ne legyenek házasok. A párkapcsolat hosszúságának tényleges ideje 211 év, átlaga 4,2 év. Ami a vizsgált személyek életkorát illeti, a nőknél a legfiatalabb 20 éves, a legidősebb 29 éves volt, átlag életkoruk 23,09 év (szórása 1,99). A férfiak között a legfiatalabb 21 éves, a legidősebb 38 éves volt, átlagéletkoruk 26,72 év (szórása 4,07). A végzettség eloszlása az első táblázatban olvasható. A kötődési stílusok eloszlását a 2. táblázat szemlélteti.

\section{1. táblázat: A vizsgált személyek iskolai végzettségének eloszlása}




\begin{tabular}{|l|c|c|c|}
\hline \multicolumn{1}{|c|}{$\boldsymbol{V E ́} \boldsymbol{G Z E T T S E ́} \boldsymbol{G}$} & Érettségi & Főiskola & Egyetem \\
\hline Férfiak & $62,5 \%$ & $12,5 \%$ & $25 \%$ \\
\hline Nők & $87,5 \%$ & $6,3 \%$ & $6,3 \%$ \\
\hline Teljes minta & $75 \%$ & $9,4 \%$ & $15,6 \%$ \\
\hline
\end{tabular}

Forrás: Saját szerkesztés

\section{2. táblázat: A kötődési kategóriák megoszlása a jelen vizsgálatban,} illetve két korábbi kutatásban

\begin{tabular}{|l|c|c|c|}
\hline \multicolumn{1}{|c|}{ Kötődési stílus } & $\begin{array}{c}\text { Bartholomew, } \\
\text { Horowitz (1991) }\end{array}$ & $\begin{array}{c}\text { Csóka és mtsai } \\
\text { (2007) }\end{array}$ & Jelen vizsgálat \\
\hline Biztonságos & $47 \%$ & $18,5 \%$ & $18,8 \%$ \\
\hline Tagadó elkerülő & $18 \%$ & $32,3 \%$ & $28,1 \%$ \\
\hline Félelemteli-elkerülő & $21 \%$ & $29,7 \%$ & $21,9 \%$ \\
\hline Aggodalmaskodó & $14 \%$ & $19,5 \%$ & $31,3 \%$ \\
\hline
\end{tabular}

Forrás: Saját szerkesztés

\section{Eredmények}

Tekintettel a nagyszámú statisztikai elemzésre, a következőkben csak azokat az eredményeket fogjuk bemutatni, amelyek statisztikailag szignifikáns és szakmailag releváns eredményeket mutatnak. A hipotézisek vizsgálatára a következő statisztikai módszereket alkalmaztuk: a Pearson korrelációt és a mediációs modellt (Barron, Kenny, 1986)

Az eredmények szerint az aggodalmaskodás magasabb értékei negatív összefüggésben állnak a kapcsolati elégedettséggel $(\mathrm{r}=-0,395, \mathrm{p}$ $<0,001)$. Az a hipotézisünk is teljesült miszerint a pozitív páros megküzdés alkalmazása magas párkapcsolati elégedettséget fog maga után vonni $(\mathrm{r}=0,594, \mathrm{p}<0,000)$. Továbbá igazolódott az is, hogy a negatív páros megküzdés alkalmazása alacsony párkapcsolati elégedettségget von maga után $(\mathrm{r}=0,584, \mathrm{p}<0,000)$. Cáfolódott viszont az a hipotézisünk, miszerint azoknál, akik jobban aggodalmaskodnak a kapcsolatok miatt, jellemzőbb lesz az átvállalt megküzdés $(\mathrm{r}=-0,350, \mathrm{p}<0,001)$.

Arra is kiváncsiak voltunk, hogy a kötődési dimenziók és az elégedettség kapcsolatát mediálja-e a diadikus megküzdés. Erre a kérdésre a mediációs modell (Baron, Kenny, 1986) segítségével próbáltunk választ keresni. Ahhoz hogy a mediációs modell feltételeit ellenőrizhessük, négy lineáris regressziót számoltunk. A mediációs modell feltételei (Tix, Frazier, 2005) a függetlenség és a kapcsolatkeresés dimenziók esetében nem teljesültek, ezért csak az aggodalmaskodás dimenzió öszszefüggéseit tudtuk ellenőrizni. Az eredmények szerint a magasabb aggodalmaskodás alacsonyabb elégedettséget, illetve alacsonyabb át- 
vállalt megküzdést jelez. Az átvállalt megküzdésen keresztül részben vezet az aggodalmaskodás magasabb párkapcsolati elégedettséghez (lásd 1. ábra). Az ábra a B értékeket mutatja a standard hibájukkal zárójelben.

1. ábra. Az átvállalt megküzdés, az aggodalmaskodás és az elégedettség kapcsolata.

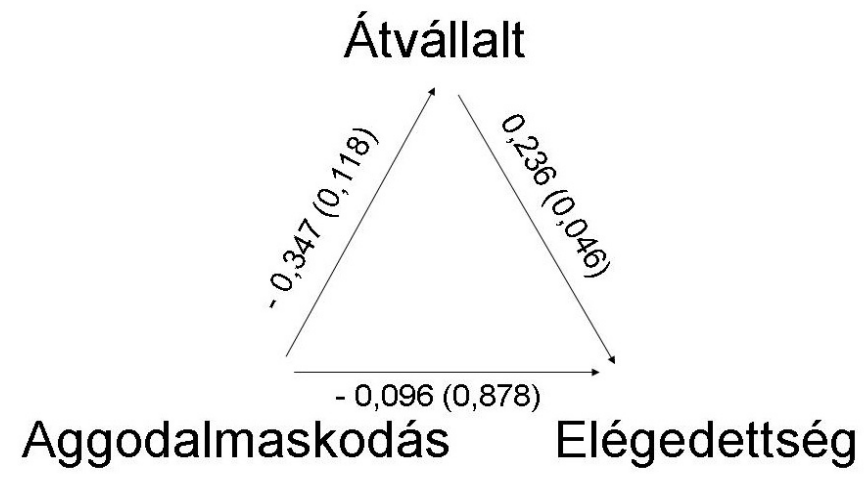

\section{Megbeszélés}

Kutatásunk célja az volt, hogy a kötődés, a megküzdés és az elégedettség összefüggéseit tárja föl, olyan személyek között, akik legalább 2 éve párkapcsolatban élnek. Vizsgálatunk legfontosabb eredményei szerint a magas aggodalmaskodás alacsony elégedettséget jelez a párkapcsolatban. Ez az eredmény megerősíti a szakirodalomi adatokat, miszerint azok a személyek, akikre jellemző az aggodalmaskodás mértéke nem tudnak adekvát módon megküzdeni a stresszel (Maunder, Hunter, 2001), fokozott gondoskodáskereséssel, veszteségtől való félelemmel, szeparáció elleni tiltakozással, (West és mtsai, 1994), féltékenységi, dührohamokkal (Feeney, 1999) jellemezhetőek.

Továbbá eredményeink szerint az aggodalmaskodás magasabb mértéke alacsonyabb átvállalt megküzdést jelez a párkapcsolatban. A szakirodalom alapján az aggodalmaskodás jellemzői a következők: másikról alkotott pozitív kép, saját magáról alkotott negatív kép (Bartholomew, Horowitz, 1991), a partnerük idealizálása, saját érzéseiket nem veszik figyelemben a partner javára (Feeney, 1999). Ugyanakkor Bodenmann feltevése szerint (2005) az átvállalt megküzdés azt jelenti, hogy a megterhelő feladatokat átveszi az illető a partnerétől. Ezek szerint a kapott 
eredmény ellentmond a logikának, mivel azt várnánk el, hogy az, aki aggodalmaskodik amiatt, hogy el fogja veszíteni a partnerét, inkább hajlamos arra, hogy mindent megtegyen ahhoz, hogy elnyerje a partnere tetszését. Utóbbi gondolatmenetet megerősítette az az eredmény, miszerint az átvállalt megküzdésen keresztül vezet az aggodalmaskodás magasabb párkapcsolati elégedettséghez.

Vizsgálatunk megerősitette, hogy a pozitív megküzdés magas párkapcsolati elégedettséggel jár együtt, miközben a negatív megküzdés alacsony elégedettséget jelez. Ezt az eredményt alátámasztják Bodenmann (2005) kutatásai, aki szerint magas elégedettséggel jellemzett párok körében jobb stressz kommunikáció, támogató diadikus megküzdés, illetve alacsony diadikus megküzdés tapasztalható.

Az előbbiekben bemutatott eredmények gyakorlati jelentősége abban állhat, hogy a párterápiával foglalkozó szakembereknek segíthet a kapcsolati minőség javításában, az elégedettség növelésében. Ennek érdekében meg lehetne tanítani a párokat konstruktívabb megküzdési stratégiák alkalmazására, hogy azok a személyek is elégedettséggel teli kapcsolatokban éljenek, akik kedvezőtlen korai tapasztalatokkal rendelkeznek.

\section{Irodalom}

BALOG és mtsai. (2006): A Rövidített házastársi stressz skála pszichometriai jellemzői. Mentálhigiéné és Pszichoszomatika, 3, 193-202.

BARON, R. M. - KENNY, D. A. (1986): The moderator-mediator variable distinction in social psychological research: Conceptual, strategic, and statistical considerations. Journal of Personality and Social Psychology, 51, 1173-1182.

BArtholomew, K. - Horowitz L. M. (1991): Attachment styles among young adults: A test of a four-category model. Journal of Personaltiy and Social Psychology, (61).2, 226-244

BodemanN, G. (2005): Dyadic coping and its significance for marital functioning. In: Reveson, T. A., Kayser K., Bodenmann, G (eds.)., Couples coping with stress: Emerging perspectives on dyadic coping. American Psychological Association, Washington DC, 33-49.

Bowlby, J. (1973): Attachment and loss: Vol 2. Separation: Anxiety and Anger. New York: Basic Books.

CsÓKA és mtsai (2007): Kísérlet a felnőttkori kötődés mérésére- A kapcsolati kérdőív (Relationship Scale Questionnaire) magyar változata. Pszichológia, (27). 4, 333355 
FEENEY J. A. (1999): Adult romantic attachments and couple relationships. In Cassidy, J., Shaver, P. R. (Eds.) Handbook of attachment: Theory, research, clinical aplications. Guilford Press. 355-377.

GRIFFIN D. W. - BARTHOLOMEW, K. (1994): The metaphyisics of measurement: The case of adult attachment. Advances in Personal Relationships, 5, 17-52

KoBAK, R. R. - HAZAN, C. (1991): Attachment in marriage: Effects of security and accuracy of working models. Journal of Personality and Social Psychology, 60, 861-869

HAZAN C. - Shaver P.(1987): Romantic love conceptualized as an Attachment process, Journal of Personaltiy and Social Psychology, (52). 3, 511-524

MARTOS, T. (2008): Házaspárok és a stressz-a megküzdés és megelőzés esélyei a párkapcsolatban. In: Kopp M. (ed) Magyar lelki állapot 2008. Esélyerösités és életminöség a mai magyar társadalomban. 230-236, Semmelweis Kiadó, Budapest.

Martos, T. - SAllay, V. - Nistor, M. - Józsa P. (megjelenés alatt). Párkapcsolati megküzdés és jóllét - a Páros Megküzdés Kérdőiv magyar változata. Kézirat, közlésre benyújtva (Psychiatria Hungarica)

MAunder, R. G., Hunter, J. J. (2001): Kötődés és pszichoszomatikus medicina: stressz és betegség megközelítése a fejlődés problémái felől; In: Kulcsár Zs., Rozsa S. (szerk) Megmagyarázhatatlan test tünetek. ELTE Eötvös Kiadó. Budapest

Pietromonaco P. R. és mtsai (2004): Conflict in adult close relationships: An attachment perspective. In: W.S. Rholes - J.A. Simpson (Eds), Adult attachment: New directions and emerging issues. New York: Guilford Press, 2004

SIMPSON és mtsai (1992): Suport seeking and support giving within couples in an anxiety provoking situation: The role of attachment styles. Journal of Personality and Social Psychology, 62, 434-446

SteUBER, K. R., (2005): Adult attachment style, conflict style, and relationship satisfaction: A comprehensive model. Faculty of the University of Delaware

TiX, A., P. - FraZIER, A. P. (2005): Mediation and Moderation of the Relationship Between Intrinsic Religiousness and Mental Health. Personality and Social Psychology Bulletin 31 (3). 295-306

TownSEND, J. (2011). Learning to bond. Learning to set boundaries. In: Carder, M.D., Henslin, E., Townsend, J. \& Cloud, H.(ed.) Unlocking your Family Patterns. Moody Publishers, Chicago

West, M. L. - Sheldon-Kellor, A. E. (1994): Patterns of relating: An adult attachment perspective. New York: Guilford Press. 


\title{
Szabó Gyula ${ }^{21}$
}

\section{A GYERMEKEK ÉLETMINŐSÉGÉNEK VIZSGÁLATA - REGIONÁLIS KÜLÖNBSÉGEK MAGYARORSZÁGON}

\author{
THE INVESTIGATION OF THE CHILDRENS' QUALITY OF LIFE - \\ REGIONAL DIFFERENCES IN HUNGARY
}

\begin{abstract}
Children's welfare has been a popular research topic in the past few decades, but researchers usually focus on the relationship between child well-being and trends in GDP. Nevertheless there are some drawbacks of using GDP per capita as an indicator of child well-being that is why a number of alternative methods were developed. Researchers agree that we still do not have effective measures to evaluate child wellbeing, this paper aims to collect some of the most important new approaches regarding this topic. The author also presents some of the territorial differences in the field of children's welfare by using statistical data from the seven regions of Hungary.
\end{abstract}

\section{Bevezetés}

Az egyenlőség és a jólét - illetve ehhez kapcsolódóan a gyermekjólét kérdéseivel foglalkozó közgazdászok jelentős része egyetért abban, hogy a gazdasági tevékenység legfontosabb célja az emberi fejlődés és jólét előmozdítása, nem pedig maga a gazdasági növekedés. Másfelöl ezek a kutatók abban is nagyrészt egyetértenek, hogy a mai napig nem rendelkezünk hatékony és megbízható eszközökkel, hogy a célok elérésére tett erőfeszítéseinket mérni tudjuk. Természetesen létezik többféle mérőszám, amelyek közül a mai napig a leggyakrabban használt a GDP, vagyis a bruttó hazai termék. A GDP arra szolgál, hogy mérhető-

${ }^{21}$ Dr. Szabó Gyula adjunktus, Debreceni Egyetem Gyermeknevelési és Felnőttképzési Kar 
vé tegyük egy adott területen meghatározott idő alatt előállított javak értékét. De azok a változásokat megtapasztalva, amelyek a társadalmakban és a világgazdaságban bekövetkeztek, illetve folyamatosan bekövetkeznek, egyre több kutató vonja kétségbe, hogy a GDP megfelelő mutatója-e az országok és azok polgárai jólétének (Eisler 2007, Stiglitz et al. 2009).

A témával foglalkozó szerzők előszeretettel hozzák fel példaként az 1980-as amerikai elnökválasztási kampányban történteket. Akkor Ronald Reagen egy egyszerü kérdés tett fel a választópolgároknak: Jobban éltek, mint négy évvel? Annak ellenére, hogy az 1976 és 1980 közötti időszakban a polgárok egy före jutó reáljövedelme 7,6\%-kal növekedett, a válasz egyértelmü nem volt. De hasonló példát hozhatunk Kanadából is a közelmúltból. 1998-ban azt a kérdést tették fel a kanadai lakosoknak egy kutatás során, hogy milyennek ítélik meg saját általános pénzügyi helyzetüket, összehasonlítva azt a szüleik generációjával. A megkérdezetteknek kevesebb, mint a fele számolt be előrelépésről annak ellenére, hogy az egy főre jutó GDP az országban ebben az időszakban közel 60\%-kal emelkedett (Osberg és Sharpe 2005).

A gazdasági fejlődés, és ezzel együtt a jólét valódi természetének jobb megértéséhez multidiszciplináris megközelítésre van szükség, ami magába foglalja a társadalom alaposabb vizsgálatát - a társadalmi jólét új megközelítésü vizsgálata egy lépés ebbe az irányba.

\section{A jólét mérésének hagyományos megközelítése}

Az 1930-as években a bruttó hazai termék fogalmát azért alkották meg, hogy rendelkezésre álljon egy olyan mérőszám, amely alkalmas a különböző piaci folyamatok összesítésére egy olyan korszakban, amikor a kormányok elsődleges célja az ipari termelés növelése volt (Cobb et al. 1997). A háborút követő időszakban vált az Egyesült Államok gazdaságpolitikájának hivatalos mérőeszközévé, amely az ipari növekedést volt hivatott mérni. A GDP rövid időn belül a nemzetek gazdasági fejlettségének és a lakosok gazdagságának legfontosabb mutatójává vált. Ugyanakkor maga Simon Kuznets, a módszer kidolgozója figyelmeztette az Egyesült Államok Kongresszusát, hogy egyetlen mutatószám semmiképpen nem lehet elegendő, hogy egy társadalom jólétét mérje. Az 1960-as években azt is hangsúlyozta, hogy különbséget kell tennünk a növekedés minősége és mennyisége között. A közgazdászok 
már a '70-es években elkezdték kritizálni a GDP-t, mint a jólét méröszámának koncepcióját.

A GDP-t általában nagyon hasznos eszköznek tekintik az ipari termelés rövid távú (néhány évet felölelő) változásainak vizsgálatára, de már korábban is egyértelmüvé vált, hogy nem alkalmas a társadalom összetett, strukturális változásainak nyomon követésére. A GDP hiányosságait már neves közgazdászok is leírták az elmúlt évtizedekben, ám a szerepe a gazdaságpolitikai döntéshozatali folyamatban kikezdhetetlennek tűnik, a tervezés és értékelés ma is nagyrészt a GDP változásait veszi figyelembe. A szakemberek számára az az egyik legnagyobb kihívás, hogy egy pontosabb indikátort találjanak, amely tükrözi a valódi társadalmi jólétet, a társadalmi fejlődés eredményeit és az emberek elégedettségét. Az alapötlet, hogy különböző gazdasági folyamatokat egyetlen, könnyen elérhető indikátorral mérjük mindenki számára vonzó volt, ám az elmúlt évtizedek során számos félreértés és téves elképzelés kísérte a kutatás folyamatát. Habár a pénz kétség kívül a társadalmi haladás egyik legfontosabb eszköze, és jó eszköze lehet a folyamatok mérésének, azonban annak a lehetősége, hogy minden értéket és fejlődést pénzben mérjünk, túlságosan vonzóvá vált a közgazdászok és a döntéshozók számára is (Jacobs and Šlaus 2010).

Számos szakember és kutatócsoport bírálja jelenleg is a GDP ellentmondásos szerepét, amit a társadalom és a polgárok helyzetének mérésében játszik a mai napig. Valójában mára ez vált a közgazdászok egyik legnépszerúbb vitatémájává, amiről számos publikáció jelent meg az utóbbi években. Elég, ha egy szerzőt említünk, akik a közelmúltban megfogalmazták meg a kétségeiket a GDP szerepét illetően. Riane Eisler (2007) elismeri a GDP szerepét gazdasági indikátorként, de arra is rámutatott, hogy összességében nem ad megbízható becslést egy ország gazdasági teljesítményét és állapotát illetően. Többek között kiemelte, mennyire fontos, hogy külön mérni tudjuk például a nők és gyermekek helyzetét is, mint a társadalom és gazdaság állapotának egyik alapvető mutatóját. Ráadásul Eisler azt is hangsúlyozza, hogy a GDP nem veszi teljes mértékben figyelembe az összes gazdasági tevékenységet az adott területen, különösen azokat nem, amelyek kívül esnek a pénzügyi szemléletü közgazdaságtan területén. Ahogy írja, a GDP nem veszi figyelembe többek között a „szociális gazdaság” teljesítményét, a háztartásban végzett nem fizetett munkát, a gyermekekkel, az idősekkel és a fogyatékkal élőkkel kapcsolatos otthoni tevékenységet. Másrészt a GDP számos olyan tételt is tartalmaz, amelyek nem járulnak hozzá a társadalmi 
jóléthez. Például egy természeti katasztrófa utáni helyreállítást költségei a GDP-ben a növekedést erösítik - miközben valójában csak arról van szó, hogy a korábbi állapotot állítják helyre. Általában elmondható, hogy a kormányzati kiadások mérése különösen nagy kihívást jelent, mivel a közszolgáltatásokat gyakran közvetlenül és ingyenesen, esetleg csökkentett áron biztosítják a rászorulók részére - így azután a GDP számolásakor nem is lehet azokat piaci áron figyelembe venni, hanem csak a bemeneti költségekkel tudunk számolni.

A közelmúltban elismert tudósok egy csoportjának lehetősége nyílt, hogy alaposan megvizsgálják ezt a kérdést, mikor a francia elnök, Nicholas Sarkozy felkérte őket, hogy alakítsanak egy bizottságot. 2008ban azzal a kéréssel fordult Joseph Stiglitz-hez (ő lett a bizottság elnöke), Amartya Senhez (tanácsadóként vett részt a munkában) és Jean Paul Fitoussihoz (a bizottság koordinátora), hogy alakítsák meg a "Commission on the Measurement of Economic Performance and Social Progress" elnevezésű bizottságot. A tagoktól, három elismert professzortól azt várták, hogy állítsanak össze egy jelentést, ami nemcsak a GDP problémáival foglalkozik, de javaslatokat is tesz a jólét mérésének alternatív módszereire is (Stiglitz et al. 2009). A bizottság célja az volt, hogy megállapítsák a GDP alkalmazhatóságának korlátait a gazdasági teljesítmény és a társadalmi haladás mérése során, illetve megállapítsák, milyen további információkra lenne szükség új, hatékonyabb indikátorok kidolgozásához. Maga az a tény, hogy Európa egyik vezető politikusa fontosnak tartotta egy ilyen bizottság létrehozását, jól mutatja, hogy itt nem egy, csupán néhány szakembert foglalkoztató kérdésről van szó. Mára egyértelművé vált, hogy az új, megbízható és valós adatokat biztosító módszerek kidolgozása a politikai döntéshozók céljai közé is bekerült.

Ahhoz, hogy pontosabban meg tudjuk mondani, miként mérhető a társadalmi jólét, elsőként természetesen meg kell határoznunk, hogy közgazdasági szempontból hogyan határozható meg a fogalom. Stiglitz a fentebb említett bizottság munkája kapcsán egy többdimenziós modellt dolgozott ki, amely a korábbi kutatási eredményeken és a gyakorlati tapasztalatokon alapul. A bizottság által összeállított a következő szempontokat emelte ki (Stiglitz et al. 2009):

- Anyagi javak (bevétel, fogyasztás, vagyoni helyzet)

- Egészség

- Oktatás 
- Személyes tevékenységek, ide értve a munkát is

- Politikai véleménynyilvánítás és kormányzás jellege

- Társadalmi kapcsolatok

- Környezet (a jelenlegi és jövőbeli állapot)

- Biztonság (gazdasági és fizikai értelemben egyaránt)

Mára az indikátoroknak széles tárháza áll a kutatók rendelkezésére, amelyek mind a gazdasági és társadalmi fejlettség fokát igyekeznek mérni a világban. A Gazdasági Együttmüködési és Fejlesztési Szervezet (ismertebb nevén az OECD) kiemelt szerepet tölt be az ehhez szükséges adatgyüjtésben, többek között adatokat gyüjtenek a termékenység, a migráció, a házasságkötések és válások, az oktatás, a munkanélküliség, a jövedelmi egyenlötlenségek, a nemek közötti gazdasági egyenlőtlenség, a szociális kiadások, a várható élettartam és az egészségügyi kiadások méréséhez. Ezeket az adatokat is felhasználva a világ több részén dolgoztak ki módszereket olyan összetett indexek létrehozására, amelyek helyettesíthetik, vagy legalábbis kiegészíthetik a GDPt. A szakirodalomban számtalan olyan mutatószámot találhatunk, amelyek jelentős mértékben különböznek egymástól a céljaikat és a felhasznált módszertant tekintve is. Az „Index of Sustainable Economic Welfare" (ISEW) például azt a fenntartható gazdasági jólétet igyekszik meghatározni, amit egy ország egy adott pillanatban, figyelembe véve a múltbéli és jelenlegi események hatásait is. A „Legatum Prosperity Index" (LPI) 79 mérőszámból áll össze, amit kilenc egyenlő súllyal figyelembe vett csoportba vonnak össze a készítői, mint például a demokratikus intézményrendszer müködése, az egészség vagy a kormányzás (ld. http://www.prosperity.com). A Happy Planet Index (HPI) egy adott országban az egységnyi ökológiai forrás felhasználásával elért „boldog évek” számát vizsgálja, vagyis megpróbálja az emberi jólétet és a környezeti hatásokat egy közös mutatóban egyesíteni (ld. http://www.happyplanetindex.org). A Genuine Progress Indicator (GPI) a személyes fogyasztási adatokból indul ki, amit azután tovább finomít több más mutató felhasználásával, mint például az önkéntes munka, a bünözés és a környezetszennyezés hatásai vagy a szabadidő mennyisége és eltöltésének módja. Valószínüleg a legtöbbek által ismert alternatíva a kizárólag a bruttó hazai terméket felhasználó módszerek leváltására a Human Development Index (HDI), ami egyesíti az egy före jutó GDP-t két másik mutatóval, az írni-olvasni tudással és a várható élettar- 
tammal. Az ENSZ évente közli az index értékét (http://hdr.undp.org) és ez a beszámoló többek között tartalmaz egy rangsort is az egyes országok HDI értékeivel. Ezt a mutatót eredetileg azért dolgozták ki, hogy megmérjék és összehasonlítsák a fejlődő illetve fejlett országok helyzetét, de manapság már széles körben alkalmazzák nemcsak országok, hanem régiók és mikrorégiók összevetésére is.

\section{Tudományos megközelítések a gyermekjólét vizsgálata során}

A gyermekjólét és az ahhoz kapcsolódó mutatók iránti növekvő érdeklődés tekinthető egyfajta reakciónak is a családi élet gyors változására, és arra az egyre jobban látható igényre, ami a gyermekekkel foglalkozó szakemberek, a társadalomtudományokkal foglalkozók és a közvélemény részéröl tapasztalható, hogy pontosabb képet kapjunk a gyermekek helyzetéről. A következőkben néhány olyan megközelítést vizsgálunk meg, amelyeket a kutatók jellemzően használnak munkájuk során.

A jogokra épülő meghatározás alapja az ENSZ közgyülése által elfogadott „A gyermekek jogairól szóló egyezmény” című dokumentum, amely egyfajta lehetőséget nyújt a gyermekjólét tudományos igényü értelmezéséhez. Az ott meghatározott négy általános alapelv összecseng azokkal az elképzelésekkel, amelyek a gyermekjóléttel foglalkozó tudományos vitákban kialakultak. A diszkrimináció tilalma (2. cikkely) rámutat például annak szükségszerüségére, hogy a speciális helyzetben lévő gyermekek szempontjait is figyelembe kell venni, mint a fogyatékkal élők, vagy az intézményi ellátást igénylök. A gyermekek érdekeinek figyelembe vételét hangsúlyozó alapelv (3. cikkely) kiemeli, hogy minden, a gyermekekkel kapcsolatos döntésnél minden érintettnek az ő érdekeiket kell szem előtt tartania, ebből is következően a gyermekjóléttel kapcsolatos elemzések esetében a vizsgálat alapegysége a gyermek kell, hogy legyen. A gyermekek helyzetének komplexitására is felhívja a figyelmet a 6 . cikkely, miközben az Egyezmény a holisztikus megközelítést tartja követendőnek a gyermekekkel kapcsolatban is, ahol az állampolgári, politikai, társadalmi és gazdasági szempontok egyforma súllyal esnek a latba. Ennek megfelelően a gyermekjóléttel kapcsolatos elképzeléseknek is többdimenziósnak kell lenniük. Végül kiemelhetjük a gyermekek saját véleményének figyelembe vételét szorgalmazó 12 . cikkelyt, amely végre elismerte a jogukat, hogy 
hallassák a hangjukat, és a véleményüket vegyék figyelembe az őket érintö ügyekben (Bradshaw et al. 2007).

Az ökológiainak nevezett megközelítés a gyermekeknek a saját fejlödésükkel és jólétükkel kapcsolatos képességeire koncentrál. Ezek olyan dinamikus folyamatok, amelyet számos tényező befolyásol, hiszen a gyermekek folyamatos interakcióban állnak a környezetükkel, így azok aktív szerepet játszanak a jólét kialakításában, és az erőforrások fejlesztésében és felhasználásában. A gyermekek elsősorban saját családjával kerül interakcióba, de emellett számos más ember és szervezet is befolyást gyakorol rá: barátok, szomszédok, az egészségügyi és gyermekgondozási rendszer, az iskola stb.. Ezek a közvetlen interakciók alakítják a gyermek mikro szintü rendszerét, ami a legerősebb hatást gyakorolja rá. A mikro szintü rendszeren belüli struktúrák, mint például a szülök, az iskola közötti kapcsolatok színtere a mezo szint. Egy szinttel feljebb, az exo szint jelenti a társadalmi összefüggéseket, amibe beletartozik a szülők kapcsolati hálója, a helyi közösség állapota, a szülök munkahelye és a média is. Az exo szint már leginkább közvetve van hatással a gyermekekre, azzal, hogy befolyásolja a mikro szinten lévő struktúrákat. Végül a makro szint a szélesebb társadalmi összefüggéseket fogja össze, mint a normák, értékek, vagy a gazdasági helyzet. Ezek a szintek külön rendszereket alkotnak, melyek dinamikusak és függetlenek, ám hatással vannak egymásra. Miközben a gyermekek és a családok kapcsolatba kerülnek ezekkel a rendszerekkel, számos akadállyal és segítő tényezővel találkozhatnak, az ökológiai megközelítés támogatói szerint ezeket tekinthetjük a gyermekjólét indikátorainak is (BenArieh 2010).

A gyermekjólét egyik tradicionálisnak nevezhető megközelítése a kérdést a gyermekek jövője szempontjából vizsgálta, ezért elsősorban az oktatásukra és a jövőbeni munkavállalási lehetőségeikre fókuszált. Habár nem megalapozatlan az az elképzelés sem, hogy a gyermekeket mint a ,jövő felnőtteit” vizsgálják, és ennek megfelelően alakítsanak ki indikátorokat, ez a megközelítés gyakran nem vesz tudomást arról, hogy a gyermekkor egy saját szociológiai jellemzőkkel bíró korszak az emberek életben. Éppen ezért a gyermekkor ,új” szociológiájának nevezett megközelítés a jelenlegi (a gyermekkor során megélt) helyzetükre koncentrál. 


\section{A gyermekjólét meghatározása és mérése}

A gyermekek életkörülményeinek vizsgálata területén jelentős előrelépés történt az elmúlt években, különösen igaz ez az Európai Unió országait tekintve. A gyermekszegénység az egyik leggyakrabban előkerülő fogalom a szociális kérdésekkel foglalkozó tudományos és szakpolitikai írásokban, és a gyermekszegénység elleni harc bekerült az EU közösségi célkitüzései közé is (Bradshaw et al. 2007). Ugyanakkor, miközben több tagállamban a gyermekjólét és ezzel összefüggésben a gyermeki jogok helyzetét folyamatosan figyelemmel kísérik nehéz, gyakorlatilag lehetetlen olyan méröszámokat találni, amelyek a kutatók és a döntéshozók által egyaránt elfogadott módon képesek lennének bemutatni a helyzetet. Különösen igaz ez a területi összehasonlítások esetében, az egyes európai országok között is megfigyelhetők eltérések a módszertanban, bizonyos országokban pedig szinte egyáltalán nem találunk ilyen jellegü kutatásokat.

A legtöbb esetben a sokak által ismert laekeni indikátorok jelenthetik a kiindulópontot az ilyen jellegü vizsgálatok során. Ezeket a mutatószámokat még 2001-ben az Európai Unió Bizottságának Laekenben tartott ülésén határozták meg. Céljuk a jövedelmi szegénység és kirekesztettség mérésének egységesítése, közös indikátorok bevezetése volt, amelyek képesek mérni azt az elörelépést, amit a szegénység és a társadalmi kirekesztés elleni küzdelemben elértek a tagországok. Az adatokat elsősorban az EU-SILC (Statistics on Income an Living Conditions) felvételből szerezték, az indikátorok alapját a relatív jövedelmi szegénységet vizsgáló mutatók adják. A mérés az egy fogyasztási egységre jutó mediánjövedelem-koncepció alapján történik, a mutatók használata során azokat tekintik szegényeknek a nemzetközi összehasonlításokban, akik a medián $60 \%$-a alatti ekvivalens jövedelemmel rendelkeznek. A mutatóknak valójában három szintje van, az első két szint indikátorai nemzetközi szinten megegyeznek, a harmadik szintet viszont az ún. nemzeti indikátorok alkotják, itt a cél a nemzeti sajátosságok bemutatása. A kutatók összesen 18 (elsődleges és másodlagos) laekeni közös indikátort használnak, további részletekért ld. Statisztikai Tükör 2008. A luxemburgi Uniós elnökség idején született jelentésükben Tony Atkinson (Atkinson et al. 2005) és kollégái azt javasolták, hogy a gyermekek helyzete kiemelt súllyal kerüljön be a szegénységgel kapcsolatos közösségi politikák és kutatások közé, de az Eurostat vezetőjének javaslata alapján csak egy gyermekekkel kapcsolatos indikátor 
került be a laekeni mutatószámok közé. A gyermekszegénységgel foglalkozó szakemberek természetesen egyáltalán nem tartják megfelelönek a gyermekek ezen csekély súlyát a szegénység mérése kapcsán, különösen a 2004-es és 2007-es bővítés után merült fel, hogy az új tagállamok nem veszik kellően komolyan a gyermekek helyzetének vizsgálatát, hiszen az Uniós irányelvek is inkább a szegénység általános vizsgálatát tüzik ki célul.

Kitekintve az Európai Unió határain túlra természetesen az Egyesült Államokban is megvannak a hagyományai az ilyen jellegü vizsgálatoknak. Az 1970-es években indított mérések elsősorban a gyermekek egészségi állapotára, az iskolában mutatott elörehaladásukra és az erkölcsi fejlödésükre koncentrált (Hur és Testerman 2010), ezek a kutatási kérdések pedig mindenképpen szükségessé tették a módszertani háttér kidolgozását is. Nem meglepő módon a definíciók terén sem sikerült teljes egyetértésre jutni az eltelt évtizedek során sem, egyetértés talán csak abban van, hogy az életminőség (vagy jólét) mérésére egyaránt használhatók leíró jellegü (objektív) és értékelő jellegü (szubjektív) módszerek, illetve ezek megfelelő kombinálása adhatja meg a leginkább megfelelő mutatót. A megfelelő mérőszámok kidolgozásának az Egyesült Államokban is jelentős szakirodalma van, csak példaként kiemelve néhányat, megemlíthetjük a Foundation for Child Development (FCD) módszerét, amely hét fő területről összeszedett, összesen 28 indikátor felhasználásával alkotta meg az ún. FCD-Land Indexet (Land et al. 2001). Az Annie E. Casey Alapítvány módszere ezzel szemben10 mérőszám felhasználásán alapul, amelyeket ők nem osztottak be fó területekre. A 10 indikátort egyesítve hozták létre a saját, Kids Count Index elnevezésü mutatójukat (The Annie E. Casey Foundation 2010). A nagyközönség és a döntéshozók számára az összevont, mindössze egy számot mutató index sokkal jobban értelmezhető, mint a számos részletet kiemelő mutatószám, ugyanakkor egy ilyen kombinált index létrehozása jóval nagyobb kihívás elé állítja a szakembereket, jóval nagyobb a hibalehetőség, illetve annak az esélye, hogy a sokféle méröszám összevonása éppen a lényeget takarja el.

\section{Regionális különbségek Magyarországon}

A Magyarországon zajló területi folyamatokkal foglalkozó szakirodalom egyik alapvető megállapítása, hogy 1990 után hazánkban újra megjelentek, illetve megerősödtek a területi egyenlőtlenségek (Oláh-Pakurár 2011). 
Ennek különböző formái közül kiemelhetjük a centrális és periférikus térségek kérdését, valamint az ún. nyugat-kelet lejtőt, de talán a leglátványosabb, mindenki által tapasztalható formája a főváros és vidék közötti különbség (Pénzes 2010). A rendszerváltást követő évek gazdasági visszaesése nem egyenlő mértékben érintette Magyarország régióit, az ipari termelés csökkenése, a munkanélküliek számának látványos emelkedése különösen a periférikus térségekben volt érezhetö.

A területi egyenlőtlenségeket a kilencvenes években a piaci folyamatok uralták, ami jellemzően a regionális fejlettségi különbségek növekedését eredményezte. A területi egyenlőtlenségek egyértelmüen a gazdasági folyamatokhoz kötődnek, a társadalmi folyamatok a már korábban is fennálló egyenlőtlenségeket alapvetően nem módosították. A régiós léptékü vizsgálatok elötérbe kerülésének oka elsősorban az, hogy nyilvánvalóvá vált: a 21. században meghatározó azoknak a gazdasági tevékenységeknek a földrajzi elhelyezkedése, amelyekből a tartós versenyelőnyök keletkezhetnek. A területi egységek akkor sikeresek, ha gazdaságuk nyitott, és az egy lakosra jutó jövedelmük tartósan magas illetve folyamatosan növekszik, a foglalkoztatási ráta magas szintü, azaz ebböl a jövedelemből a lakosság széles rétegei részesülnek, vagyis a jólét szintje magas (Rőfi 2006). A területi egyenlőtlenségek megléte kapcsán teljes az egyetértés a témával foglalkozó szakemberek körében, ugyanakkor megoszlanak a vélemények abban a kérdésben, hogy hogyan értékelhető ez a folyamat. Kiemelhető itt Enyedi György véleménye, aki szerint az 1990-es évek második felében egyes területeken megkezdődött a kiegyenlítődés, miközben azt is elismeri, hogy vannak olyan területek is, amelyek további leszakadása elkerülhetetlennek látszik (Enyedi 2004). Kovács Tibor inkább azt hangsúlyozza, hogy azokban a térségekben, ahol a szerkezetváltás sikeresen zajlott le, a gyorsabb gazdasági növekedés inkább az egyenlötlenségek növekedéséhez járult hozzá (Kovács 2002).

Az utóbbi évtizedek másik kulcsszava az „emberi tényező”, ami egyre fontosabb szerepet kap, illetve minden más tényező is, ami ezzel valamilyen kapcsolatban van, felértékelödik. Erre példakánt hozhatjuk az életminőség kérdését, mint klasszikus példát, hiszen ez alapvetően meghatározza - természetesen más tényezők, mint például az oktatás mellett - az emberi erőforrások állapotát egy adott régióban. A tudásalapú gazdaság megszületése egyrészt együtt járt a tudás szerepének felértékelődésével a gazdasági növekedés értelmezésében, miközben a globalizációs folyamatok, ide értve első sorban az internetes technológiák gyors fejlődésével a földrajzi távolságok könnyen áthidalhatóvá váltak. 


\section{1. ábra. A családsegítő szolgáltatást igénybe vevök aránya a régiókban 2011-ben (a 0-13 éves népesség százalékában)}

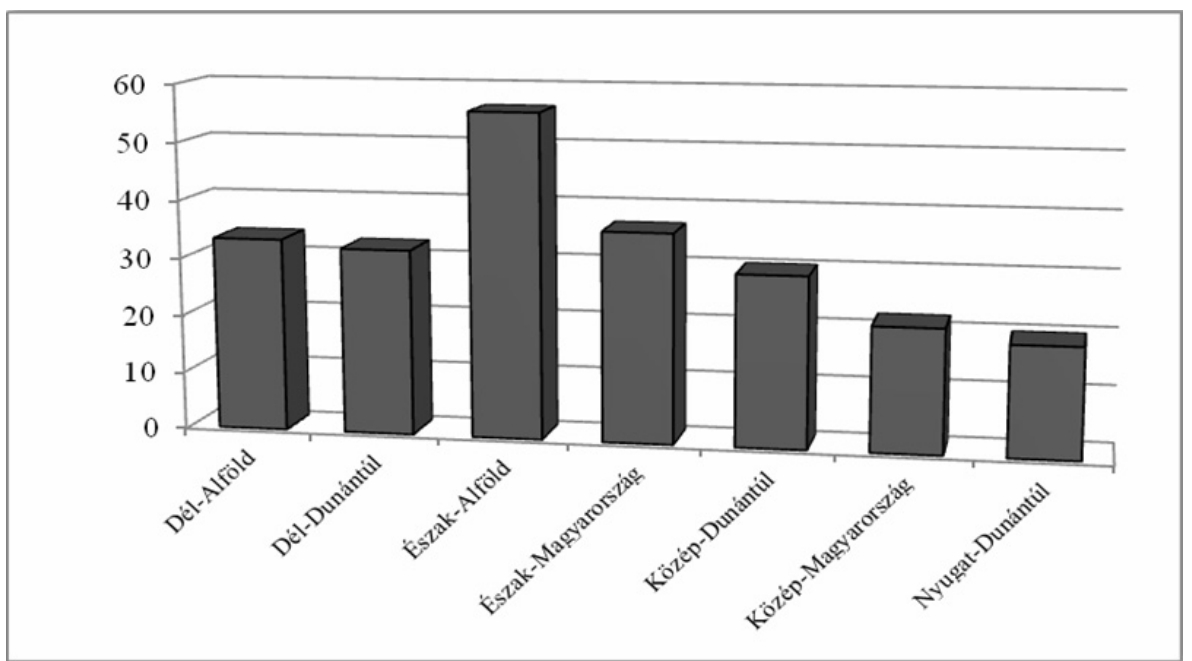

Forrás: Saját szerkesztés a KSH adatai alapján

Magyarországon évszázadok óta meghatározó a főváros-vidék közötti fejlettségi és fejlődési különbség, amelyet részben Budapest történetileg kialakult szerepe indokol. A fóváros gazdasági átalakulását az üzleti szolgáltatások és a kereskedelem fejlődése vezérli, amihez alapjaiban átalakult szervezeti és foglalkoztatási szerkezet társul. Kapcsolatai meghatározó arányban a világgazdaság központjaihoz kötődnek és érzékelhetően lazult az a közvetlen irányítási függőség, ami a korábbi évtizedekben a vidék gazdaságát a fővároshoz kötötte. A Közép-magyarországi régiónak jelentős a túlsúlya a korszerünek tekinthető és magas hozzáadott-értéket képviselő ágazatokban, mint az üzleti szolgáltatások, a kutatás-fejlesztés, az idegenforgalom, valamint az ország gazdasági teljesítőképességét (GDP/fö) tekintve, és ez - mint jelen tanulmány eredményeiből is látható - hatással van nem csak általában az ott élök jólétére, de meglehetősen látványosan a gyermekek helyzetére is. A gazdasági fejlettség, a lakossági jövedelmek és a munkanélküliség jellemzőit vizsgálva az ország határozott nyugat-kelet megosztottsága szembetünő. Különösen Nyugat- és Közép-Dunántúl sikeres szerkezetváltása és megújulása állítható szembe Észak- és Kelet-Magyarország elhúzódó stabilizálódásával. 


\section{A gyermekjóléti rendszer néhány mutatója a magyarországi régiókban}

A fentebb már említett fejlettségi különbség a főváros és a vidék, valamint a keleti és nyugati régiók között nagyon jól megfigyelhetök az általunk kiválasztott statisztikai mutatókat vizsgálva is. Rögtön az 1 . ábrát megvizsgálva tapasztalhatjuk a fenti állítások érvényességét, hiszen a családsegítő szolgáltatást igénybe vevők aránya a nyugatdunántúli és a közép-magyarországi régiókban a legalacsonyabb, a legmagasabb pedig abban a két régióban, amelyeket a legtöbb gazdasági és társadalmi mutató alapján a legrosszabb helyzetünek tekinthetünk, vagyis Észak-Magyarországon és az Észak-Alföldön.

\section{2. ábra. A védelembe vett kiskorú gyermekek aránya régiónként 2011-ben (a 0-13 éves népesség ezrelékében)}

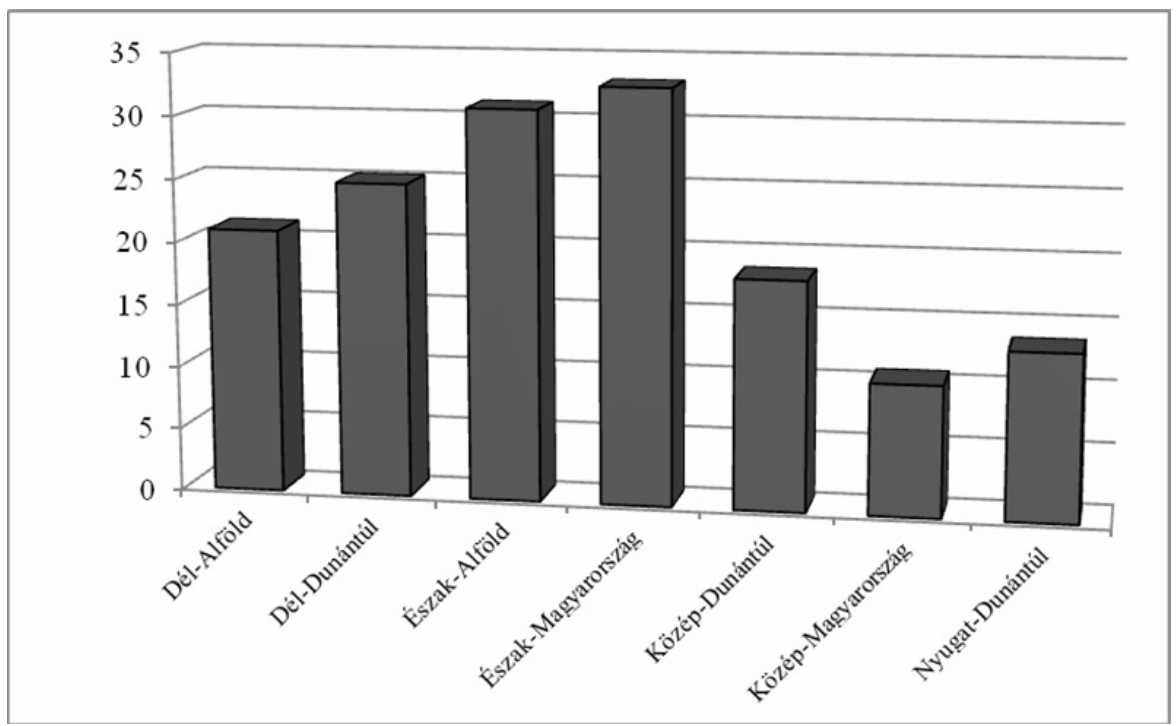

Forrás: Saját szerkesztés a KSH adatai alapján

Figyelembe kell vennünk ugyanakkor azt is, hogy a családsegítő szolgáltatás igénybe vétele nem feltétlenül csak az adott terület fejlettségétől, az ott élő gyermekek szociális helyzetétől is függ, befolyásolhatják egyéb tényezők, mint a szolgáltatások területi kiépítettsége, a rendszer elérhetösége, vagy akár az, hogy a régióban milyen a településstruktúra, milyen a falvak és városok aránya, hol találhatók a családsegítő intézmények. 
Ezért megvizsgáltunk két másik mutatót is, amelyek még jobban mutathatják az adott területen élő gyermekek életminőségét, mivel kevésbé érzékenyek a szubjektív tényezők hatásaira.

\section{3. ábra. A veszélyeztetett kiskorú gyermekek aránya régiónként 2011-ben (a 0-13 éves népesség százalékában)}

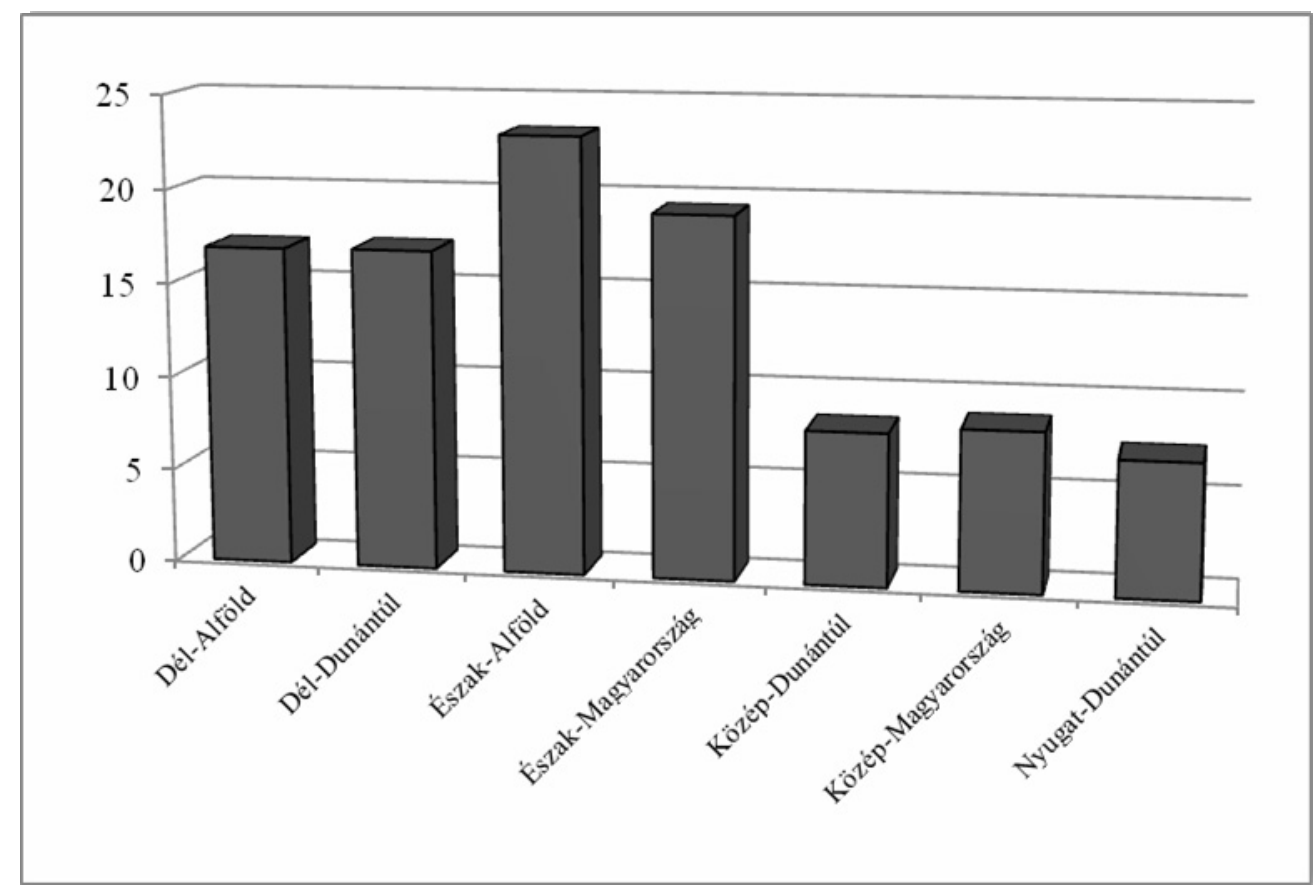

Forrás: Saját szerkesztés a KSH adatai alapján

A 2. és 3. táblázat a védelembe vett kiskorú gyermekek arányát, illetve a veszélyeztetett kiskorú gyermekek arányát mutatja az egyes magyarországi régiókban, az összehasonlíthatóság érdekében a 0-13 éves korcsoport arányában. Mindkét grafikon árnyalja, ugyanakkor teljes mértékben megerősíti az 1. ábra alapján bemutatott helyzetet, különösen a veszélyeztetett gyermekek esetében látható egyértelmüen, hogy a három legjobb helyzetben lévő régió a nyugat-dunántúli, a közép-dunántúli és a középmagyarországi. Nagyon jól látható, hogy a milyen éles határvonal húzódik a gyermekek helyzetét illetően is az országon belül. Az ország keleti és délnyugati részében mindenhol 15\% felett van a veszélyeztetett gyermekek aránya, miközben a „szerencsésebb” régiókban ez az érték mindenhol jóval 10\% alatt marad. Miközben a tanulmány első felében azt igyekeztünk bemutatni, hogy a szakemberek ma nagyrészt azon a véleményen 
vannak, hogy a GDP önmagában nem mutatja jól a gyerekjólétet egy adott területen, a saját adatainkat vizsgálva azt tapasztaljuk, hogy a legmagasabb GDP-vel rendelkező régiók minden mutató tekintetében jobban állnak. Ez természetesen nem jelenti, hogy a gyermekjólét pusztán a bruttó hazai termék függvénye, ám az összefüggés mindenképpen megfigyelhető.

\section{4. ábra. A veszélyeztetett kiskorú gyermekek száma 2008 és 2011 között)}

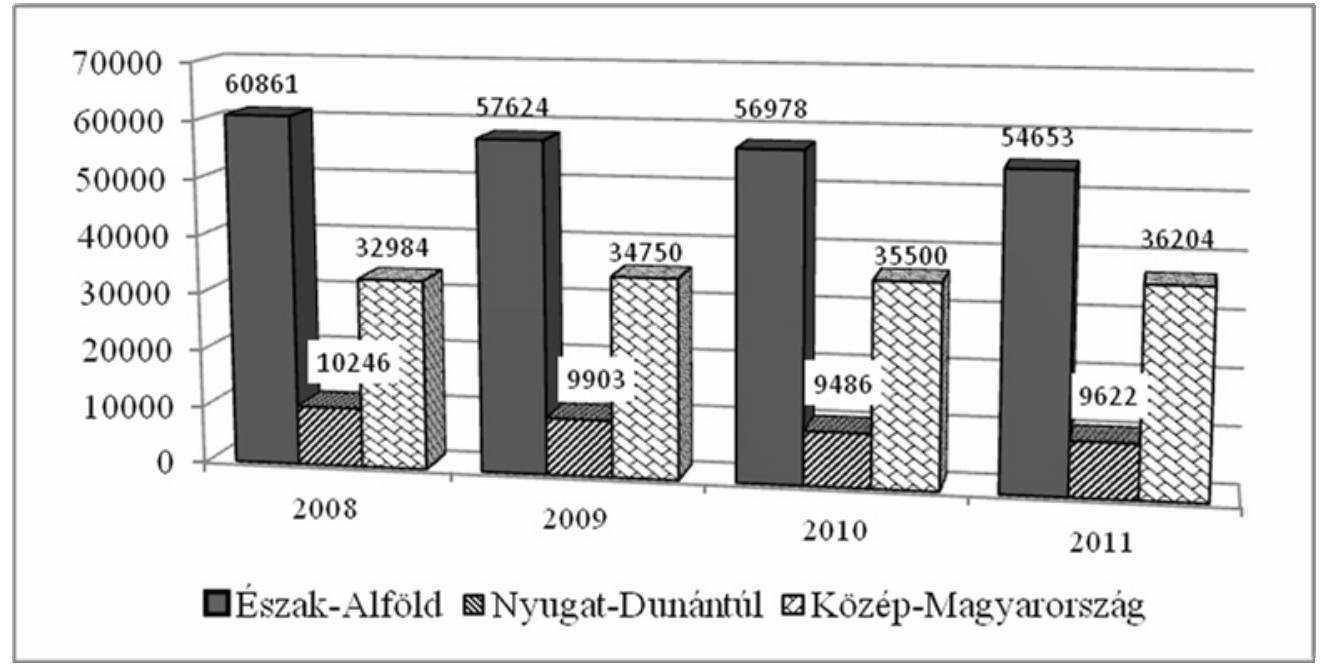

Forrás: Saját szerkesztés a KSH adatai alapján

A területi egyenlötlenségek vizsgálatának másik fontos területe annak ellenőrzése, hogy az egyenlőtlenségek vajon nőnek, vagy csökkennek. Ezért foglaltuk össze a 4. ábrán a veszélyeztetett korú gyermekek számát három régióban 2008 és 2011 között. A legjobb helyzetben lévő Nyugat-Dunántúl és Közép-Magyarország mellett a minden szempontból legrosszabb mutatókat produkáló Észak-Alföldet vontuk be a vizsgálatba. Messzemenő következtetéseket természetesen nem lehet levonni négy év adataiból, de az látható, hogy a regionális különbségek az elmúlt években láthatóan csökkentek, még ha nem is látványosan. Az mindenképpen pozitív fejlemény, hogy az Észak-Alföldön több ezerrel csökkent a veszélyeztetett gyermekek, az már kevésbé, hogy a területi kiegyenlítödés részben azért valósul meg, mert a jó helyzetben lévő régiókban vagy emelkedik (Közép-Magyarország) vagy gyakorlatilag stagnál (Nyugat-Dunántúl) ez a szám. 


\section{Irodalom}

AtKinson, A.B., B. Cantillon, E. Marlier and B. Nolan (2005): Taking Forward the EU Social Inclusion Process, Final Report. (Government of Luxembourg, Luxembourg)

Ben-ARIEH, A. (2010): From ChildWelfare to Children Well-Being: The Child Indicators Perspective. In: From Child Welfare to Child Well-Being - An International Perspective on Knowledge in the Service of Policy Making (Children's Well-Being: Indicators and Research, Vol 1) pp. 26-39.

Bradshaw, J., Hoelscher, P., Richardson, D. (2007): An Index of Child Well-being in the European Union. In: Social Indicators Research. Volume 80. pp. 133-177.

EISLER, R. (2007): Real Wealth of Nations. San Francisco, CA: Berrett-Koehler Publishers.

ENYEDI Gy. (2004): Regionális folyamatok a posztszocialista Magyarországon. Magyar Tudomány, (49. (111.) évf.) 9. pp. 935-941.

CobB, C. - Halstead, T. - Rowe, Jonathan (1997): If the GDP is Up, Why is America Down? Atlantic Monthly, October 1995

Hur, Y., Testerman R. (2010): An Index of Child Well-Being at a Local Level in the U.S.: The Case of North Carolina Counties

JACOBS, G. - ŠLAUS, I. (2010): Indicators of Economics Progress: The Power of Measurement and Human Welfare. CADMUS, Volume 1, pp. 53-113.

KovÁcs T. (2002): A területi fejlettségi különbségek alakulása Magyarországon. Területi statisztika, 6. pp. 506-517.

Laekeni indikátorok (A társadalmi kirekesztődés nemzetközi összehasonlítására szolgáló jelzőszámok) (2008): Statisztikai tükör 2008. 104. sz. KSH

LAND, K. C., LAMB, V. L., \& MustiLlO, S. K. (2001): Child and youth well-being in the united states, 1975-1998: Some findings from a new index. Social Indicators Research, 56(3), 241-320.

OLÁH J., PAKURÁR M. (2011): A foglalkoztatás tendenciája az EU-27 különbözö fejlettségü régióiban. In: Munkaügyi Szemle Stúdium Munkaügyi Szemle I, pp. 1-7.

PÉNZES J. (2010): Területi jövedelmi folyamatok az Észak-alföldi régióban a rendszerváltás után. Debrecen, Debreceni Egyetemi Kiadó.

Stiglitz, J. E. - Sen, A. - Fitoussi, J. P. (2009): "Report by the Commission on the Measurement of Economic Performance and Social Progress." Paris: Commission on the Measurement of Economic Performance and Social Progress.

The Annie E. Casey Foundation. (2010): 2009 kids count data book: State profiles of child well-being. Baltimore: The Annie E. Casey Foundation. 